


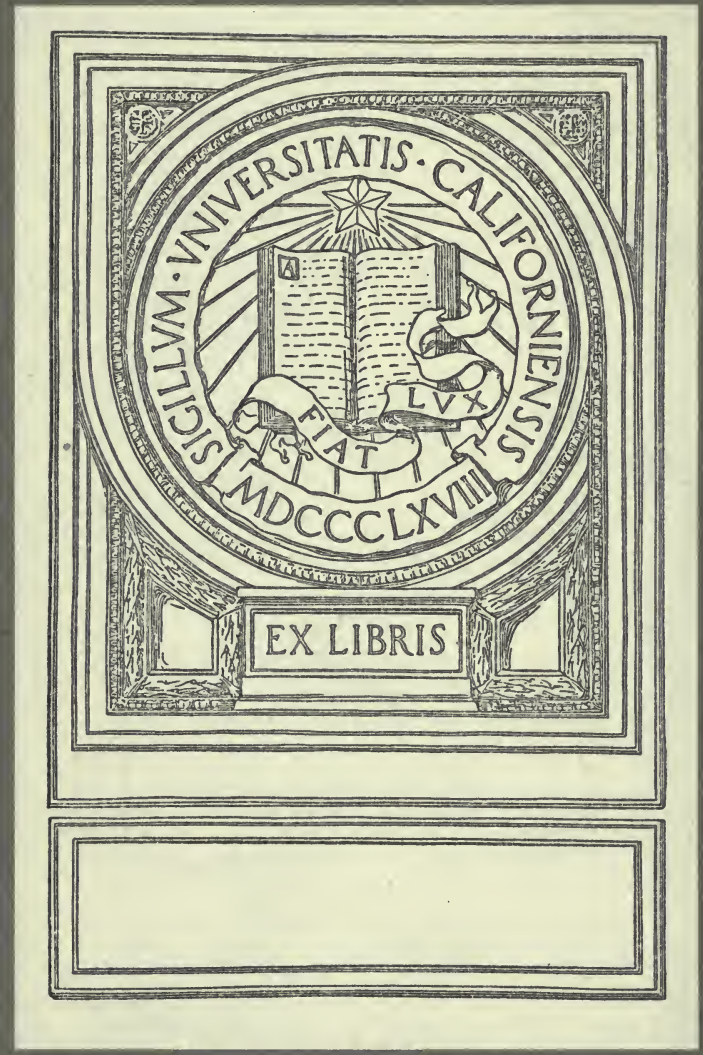




\section{- 1}

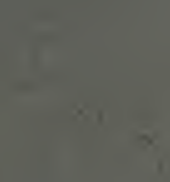


If $=-1, y$

$1=$

i. i $^{1}$ $x^{11}=$

\section{1}

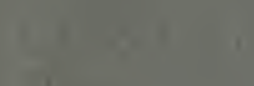
E.t.

in

$=$

\&

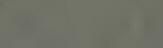


Digitized by the Internet Archive in 2007 with funding from Microsoft Corporation 



$$
\begin{aligned}
& \text {. } 4=2+4= \\
& \text { 3. }
\end{aligned}
$$

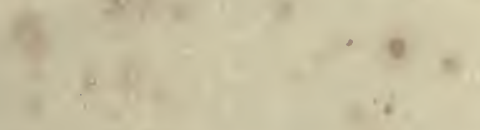

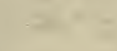

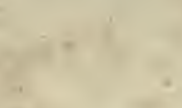

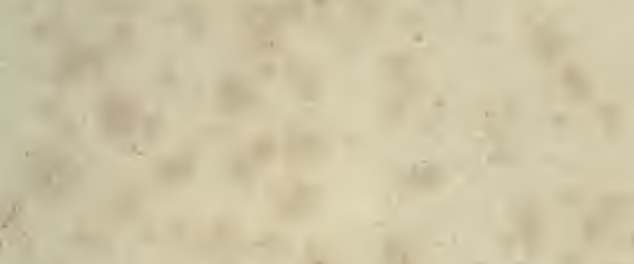

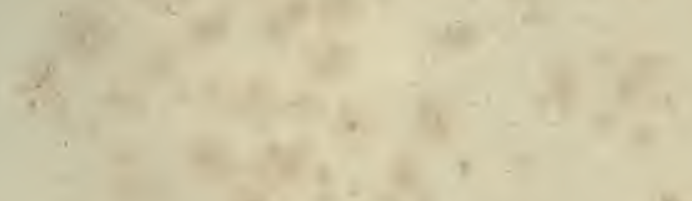

$$
\begin{aligned}
& \text { S.4. } 6
\end{aligned}
$$

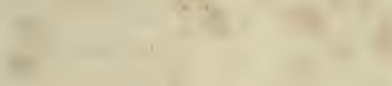

$$
\begin{aligned}
& 18,1= \\
& \because=\quad \because \\
& + \\
& \begin{array}{l}
* \\
i
\end{array} \\
& x_{y}+i=n
\end{aligned}
$$




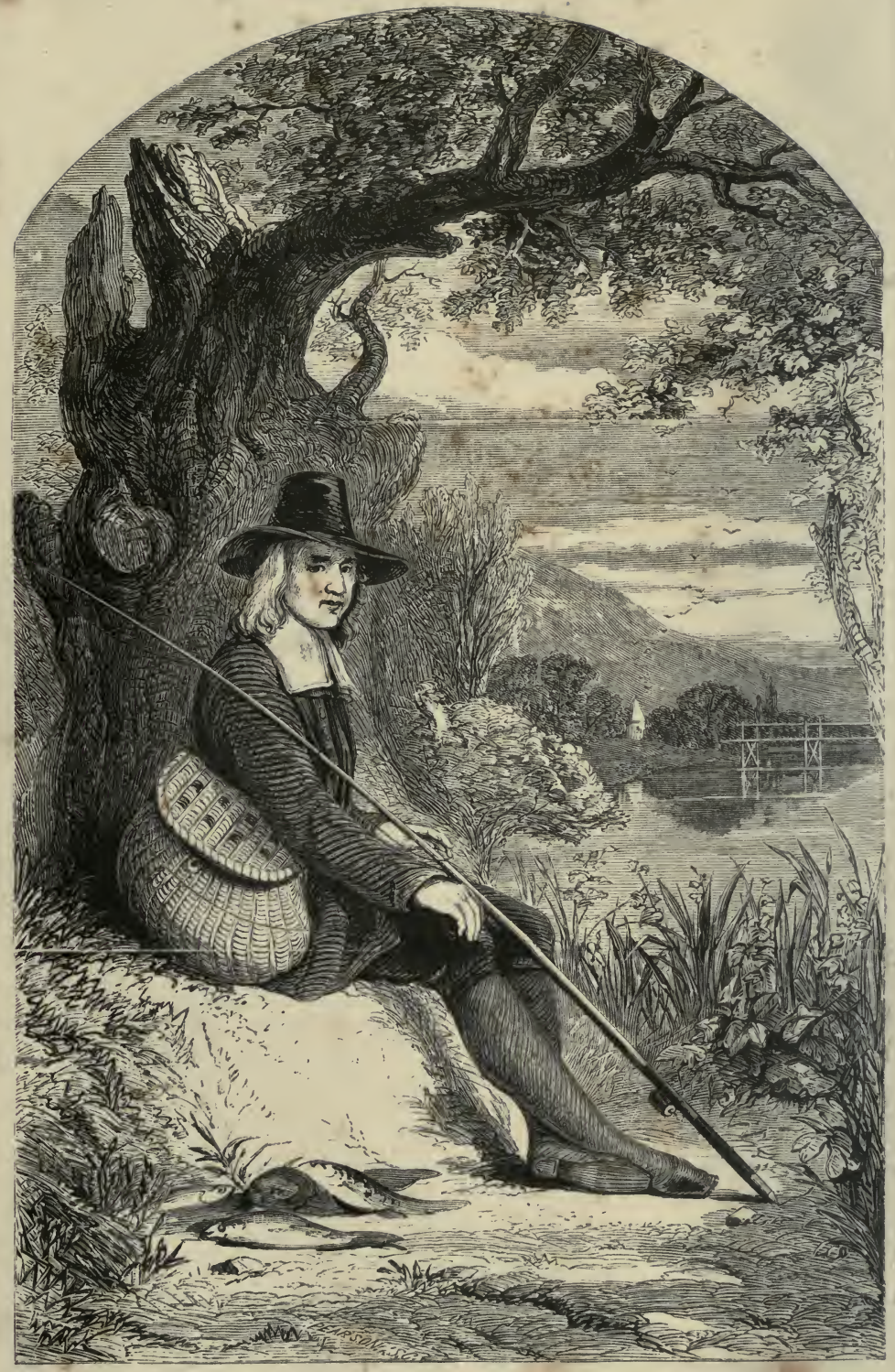




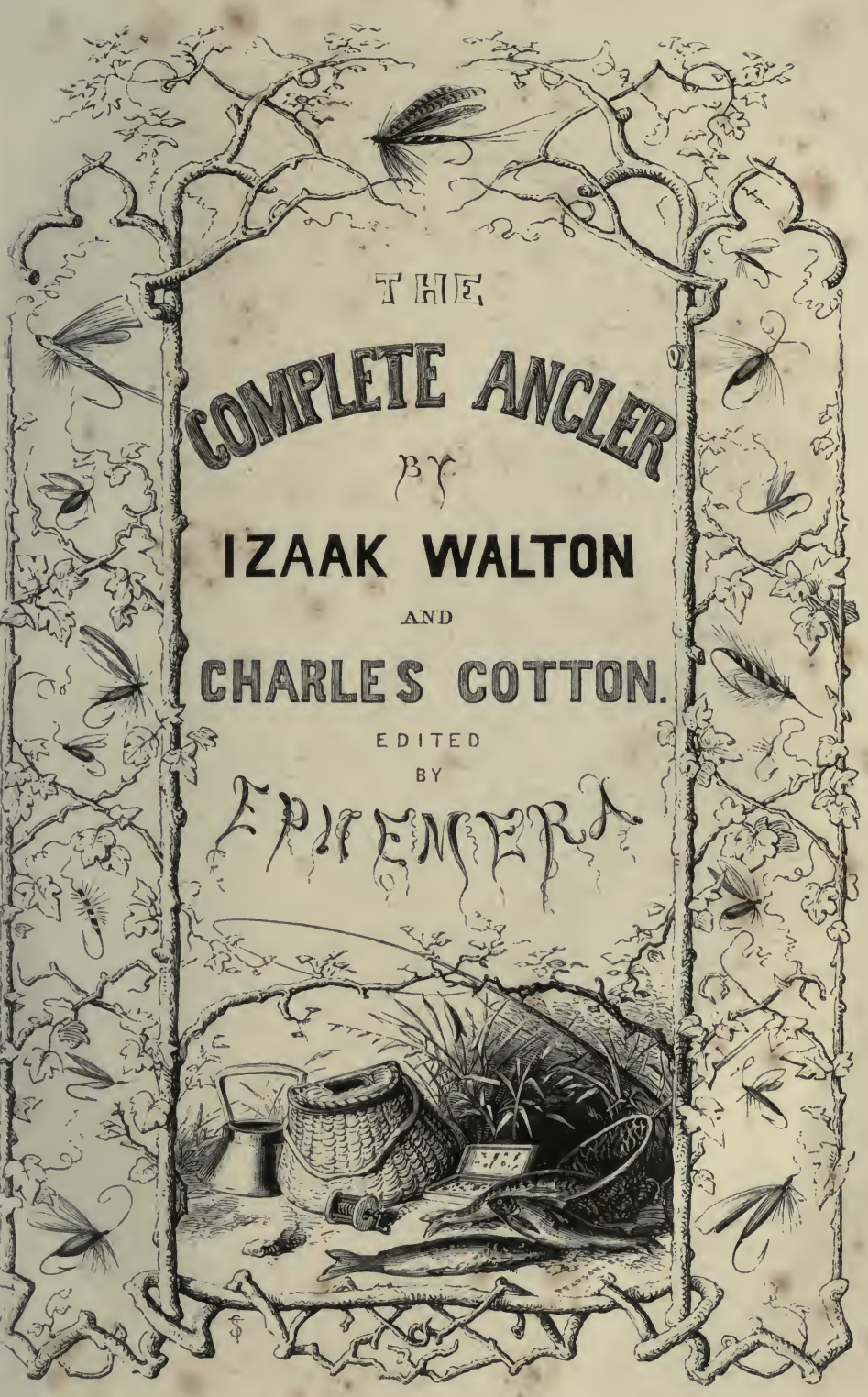

ROCTLEDGE, WARNES, \& POUTLEDGE, FARIINGDON STKEEI'. 
a)

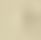

4

$2^{\circ}$

4

$+$

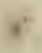

i

r r

x $=1$

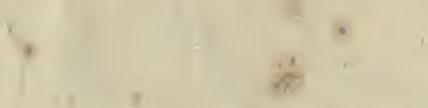

$+$

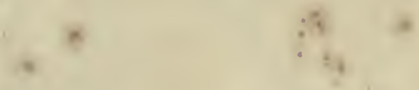

.

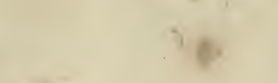

4

\section{tr}

w istris 8

$\therefore$

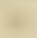

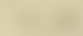

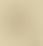
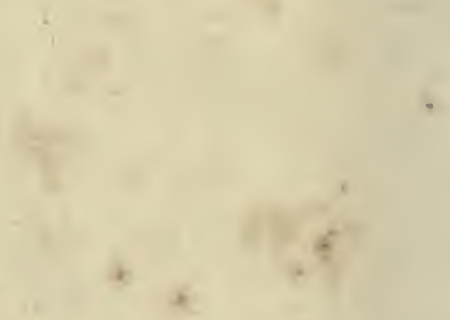

and -2

4<smiles>CCC</smiles>

. 


\section{COMPLETE ANGLER.}

$\mathrm{B} \Gamma$

IZAAK WALTON \& CHARLES COTTON.

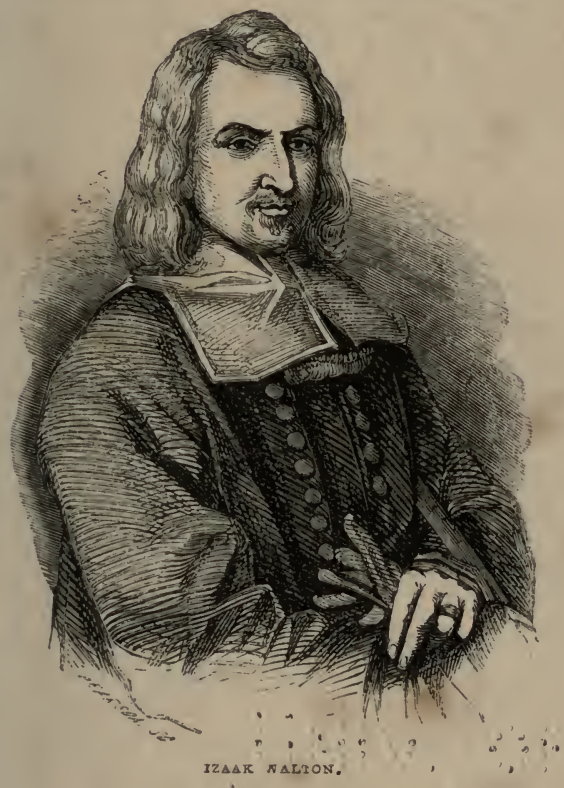

EDITED BV :EPHFMLEA, , , ", OF "BELL'S LIFE IN LONDON."

\section{LONDON :}

ROUTLEDGE, WARNES, AND ROUTLEDGE, FARRINGDON STREET.

NEW YORK: 56, WALKER STREET.

1859. 
$s$

$*$

$x$

$5+4432$

A

1859

(4)

$$
395679
$$

a

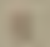

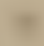

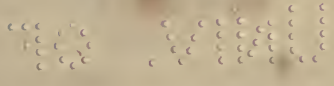

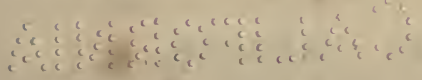




\section{ADVERTISEMENT.}

For some years past I have been turning over in my mind the possibility, having been long clearly convinced of the necessity, of publishing, a new, a cheap, a pleasantly and profusely and profitably illustrated edition of the "CoMplete ANGLER," with what I will call "modernizing" notes and additions. I have ever found all things reasonable in desire, possible of execution: and happily, the thorough fulfilment of this last aspiration of mine has proved no exception to my experience.

Having been not altogether a silent observer of the successful progress through the reading world of the cheap series of books, old and new, published by Messrs. Ingram, Cooke, \& Co., under the general and appropriate title of "The Illustrated National Library," I resolved to try and add one more to the number. To the above firm, full of public spirit and intelligent energy, I communicated my intentions and projects. They were approved of; and the offer on my part to carry them into effect, under certain conditions and with aid specified, was as freely accepted and ratified by the gentlemen named, as it was conscientiously and hopefully proposed. Hence Walton and Cotton in a modern dress, ornamental and useful.

Reader, fear not. I have touched with no profaning pen the sacred text of those venerable writers. You have it here in its primitive purity - word after word, as it was printed in the fifth and last edition, published in the year 1676, under the eyes and hands of the authors. What more have I done? A great deal-which I will briefly tell you.

The first edition of the "CoMplete ANGLER" appeared in 1653, exactly two hundred years ago, and though during Walton's lifetime four subsequent editions were published, with additions and improvements, original errors in the natural history of quadrupeds, birds, fishes, and insects, not only remained, but were augmented. Those errors must be imputed to the general ignorance of the time in which Walton wrote, in matters of natural history, and not to his specifically. The most glaring and dangerous of those errors I have cleared away by means of foot-notes. 
If any candid reader of apprehensive mind will peruse the "CoMPLETE AvGLER" he must agree with me that it lacks the instructive element-it amuses far more than it teaches-it talks more of fish and of catching them than it shows by detailed practical directions how to catch them. Occasionally directions are given; but they are not always correct, and, except in a few instances, they are antiquated and not unfrequently erroneous. At least I think so; and have endeavoured to apply a remedy. Wherever $I$ have found the piscatorial directions of Walton and Cotton right $I$ have said so, and not interfered. Where $I$ have found them contrariwise, I have pointed it out and written new instructions, frequently at great length-more lengthened than the original chapters to which they stand appended.

I will not encroach upon the reader's time by stating minutely all that I have done. In a word, I will at once and fearlessly predicate that $I$ have written, by mean's of foot-notes and complementary essays to chapters, a complete modern treatise on the different branches of angling-on bottom-fishing, spinning, and trolling, on fly-fishing with the artificial fly, and on daping or dibbing with the natural one. I have written succinctly the natural history of each of our river-fish-that of the salmon rather lengthily than succinctlyI have shown their habits, pointed out their haunts, named the best baits for them, and shown how they are to be used. I have taught how the rod and line are to be handled, and how the artificial fly is to be thrown and worked in the water, as far as a long-practised pen can teach it. I have described the best sorts of angling gear; and to Cotton's instructions for making artificial flies I have added my own, elucidated with drawings of the natural fly and of the artificial one in its finished state and in the incipient and progressive stages of its fabrication.

Of what I have done, enough. The book will tell its own tale -one I trust that will not dim, by even a passing shade, the reputation of him who, for more than fifteen years, has been the piscatory preacher of Bell's Life, who has written A Hand-book of Angling, and The Book of the Salmon, and more besides-in fine, reader, of your tutor, brother and friend,

London, March, 1853.

EpHemera.

N.B.-The notes signed "H." are from Sir John Hawkins's edition of Walton : those with "ED." attached are original. 


\section{SKETCH OF WALTON'S LIFE.}

ThF fame of Petrarch rests upon his Sonnets, and not upon his larger Italian poems, or upon his elahorate Latin ones, on which he relied for immortality. The fame of Walton-and wide and perennius cere is that fame-rests upou his simply written "Complete Angler," and not by any means on works which very likely he more prized, viz., "The Lives of Donne, Wotton, Hooker, Herbert, and Sanderson," and poems that he wrote or edited. Why so? Because the "Complete Angler" is so written, that it not only comes home to the "hearths and bosoms" of all anglers, but nearly of all men. It is au angling pastoral, babbling of all things that " are in the heavens above, the earth beneath, or in the waters under the earth." The immortal author of it was born at Stafford, in the month of August, 1593. We hear no more of him until he attained his 30 th year, when he is found carrying on the business of a "sempster," or man-milliner, in London. His first shop was a very small one, situate in the "Royal Burse," Cornhill ; that is to say, the Royal Exchange. "Yet here," writes Sir Joln Hawkins, "did he carry on his trade till some time before the year 1624 : when he dwelt on the north side of Fleet-street, in a house two doors west of the end of Chancery-lane, and abutting on a messuage known by the sign of the 'Harrow,' now the old timber-house at the sonth-west corner of Chancery-lane" (the house is now a goldsmith's, No. 128). Here he carried on the business of a linendraper, cccupying only half a shop, the other balf belonging to John Mason, a hosier.

Walton did not marry until he was about forty years of age, and then, in 1632, he removed to a house in Chancery-lane, then seven doors higher up than the corner house on the left hand, or western side. Here he resumed his old trade as a sempster, or milliner. His wife was the sister of Dr. Kenn, Bishop of Bath and Wells, one of the seven bishops sent to the Tower in the reign of James II. She was a prudent and pinus woman, largely accomplished, and in her society Walton enjoyed content and happiness. He left business and London, 1643-at the age of fifty -on a fair competency, and lived sometimes at Stafford, and elsewhere ; but mostly in the families of eminent English clergymen, by whom he was much beloved. His favourite recreation whilst in London was angling, in which art he was considered the greatest proficient of his day. The rivers he frequented, were the Lea and New River, and nccasionally, in all probability, the Thames. The first edition of his "Complete Angler" appeared in 1653, when he was in his sixtieth year, and its popularity was so great, that it ran through four editions in the space of twentythree years. Walton, in the year 1676, and in the eighty-third year of his age, was preparing a fifth, with additions, for the press ; when $\mathrm{Mr}$. Cotton wrote the second part of the work. It seems Mr. Cotton sub-. 
mitted the manuscript to Walton's perusal, who returned it with his approbation, and a few marginal strictures : and in that year they came abroad together. Mr. Cotton's book had the title of the "Complete Angler. Part II. : being Instructions how to angle for Trout or Grayling, in a clear Stream ;" and it has ever since been received as a Second Part of Walton's book. In the title-page is a cipher composed of the initial letters of both their names; which cipher, Mr. Cotton tells us, he had caused to be cut in stone, and set up over a fishing-house, that he had erected near his dwelling, on the bank of the lovely river Dove, which divides the counties of Stafford and Derby.

Mr. Cotton's book is a judicious supplement to Walton's ; for it must not be concealed, that Walton, though he was so expert a bottom-angler, knew but little of fly-fishing; and indeed he is so ingenuous as to confess, that the greater part of what he said on that subject was communicated to him by Mr. Thomas Barker, ${ }^{*}$ and not the result of his own experience. And of Cotton it must be said, that living in a country where fly-fishing was, and is, almost the only practice, he had not only the means of acquiring, but actually possessed more skill in the art, as also in the method of making flies, than most men of his time. His book is, in fact, a continuation of Walton's, not only as it teaches at large that branch of the art of angling which Walton had but slightly treated on, but as it takes up Venator, Walton's piscatory disciple, just where his master had left him ; and this connexion between the two parts will be clearly seen, when it is remarked, that the traveller whom Cotton invites to his home and so hospitably entertains, and also instructs in the art of fly-fishing-we say this traveller-and, Venator, the pupil of Walton, come out to be one and the same person. Not farther to anticipate what will be found in the Second Part, it shall here suffice to say, that there is great spirit in the dialogue; and that the same conversible, communicative temper appears in it, that so eminently distinguishes the piece it accompanies.

In 1662, Walton lost his wife. She was buried in the cathedral church of Worcester, and her monumental inscription tells, that she was "a woman of remarkable prudence, and of primitive piety; her great and general knowledge, with such true humility, and blest with such Christian meekness, as made her worthy of a more memorable monument." She left offispring, a son, called after his father, Izaak, a daughter, named Anne, after herself. The son entered into holy orders, and became chaplain to Dr. Seth Ward, bishop of Sarum, by whose favour he attained to the dignity of a canon residentiary of that cathedral. He died at the age of sixty-nine, much respected, for his good temper, discretion, candour and sincerity, by all the clergy of the diocese. The daughter married Dr. W. Hawkins, prebendary of Winchester.

In 1683, when he was ninety years old, Walton published, "Thealmar and Clearchus, a pastoral history, in smooth and easy verse, written long since by John Chalkhill, Fisq.; an acquaintance and friend of Edmund Spencer." To this poem he wrote a preface, containing a very amiable

* This gentleman published, in the year 1651, two years previously to the appearence of Walton's work, a book entitled " The Art of Angling," dedicated to Lord Montague. It was reprinted in 1653 , and again in 1659 , with the enlarged title of "Barker's Delight, or the Art of Angling." Though an earlier writer than Walton, the latter has been designated, "the common father of all anglers." 
character of the author. He lived but a very little time after the publication of this poem, for, as Wood says, he ended his days on the fifteenth day of December, 1683, in the great frost, at Winchester, in the house of the above-named Dr. William Hawkins. He was buried in the Cathedral, and in a chapel in the fourth aisle, called Prior Silksteed's chapel : on a large black flat marble stone is this inscription to his memory, the poetry whereof has very little to recommend it.

HERE RESTETH THE BODY OF

\section{R. I S A C W A L T O N,} WHO DYED THE 15TH OF DECEMBER, 1683.

Alas! he's gone before,

Gone to return no more;

Our panting breasts aspire

After their agéd sire,

Whose well-spent life did last

Full ninety years and past :

But now he hath begun

That which will ne'er be done,

Crown'd with eternal bliss,

We wish our souls with his.

Votis modestis sic flerunt liberi.

Between Walton's retirement from business and his death, he wrote the lives* of Dr. Donne, Sir Henry Wotton, Mr. Richard Hooker, Mr. George Herbert, and Dr. Sanderson, bishop of Lincoln, all learned and pious men. He also wrote a few copies of verses on minor passing events.

Upon a retrospect of the foregoing particulars, and a view of some others mentioned in a subsequent letter and in his Will, it will appear that Walton possessed that essential ingredient in human felicity, "mens sana in corpore sano ;" for in his eighty-third year he professes a resolution to begin a pilgrimage of more than a hundred miles, into a country the most difficult and hazardous that can be conceived for an aged man to travel in, to visit his friend Cotton, and doubtless to enjoy his favourite diversion of angling in the delightful streams of the Dove, -and on the ninetieth anniversary of his birthday, he, by his Will, declares himself to be of perfect memory.

As to his worldly circumstances-notwithstanding the adverse accident of his being obliged, by the troubles of the times, to quit London, and his occupation-they appear to have been commensurate, as well with the wishes as the wants of any but a covetous and intemperate man; in his relations and connexions, such a concurrence of circumstances is visible, as it would be almost presumption to pray for.

For-not to mention the patronage of those many prelates and dignitaries of the church, men of piety and learning, with whom he lived in a close intimacy and friendship; or, the many ingenious and worthy persons with whom he corresponded and conversed; or, the esteem and respect testified by printed letters and eulogiums which his writings had procured

* A remarkably cheap illustrated edition (price One Shilling) of them forms the second number of "The Universal Library," publishing this (1853) year, by Ingram, Cooke, and Co. 
him; to be matched with a woman of an exalted understanding, and a mild and humble temper, to have children of good inclinations and sweet and amiable dispositions, and to see them well settled, is not the lot of every man, who, preferring a social to a solitary life, chooses to become the head of a family.

But blessings like these are comparatively light, when weighed against those of a mind stored like his with a great variety of useful knowledge, and a temper that could harbour no malevolent thought or insidious design ; nor stoop to the arts of fraud or flattery, but disposed him to love and virtuous friendship, to the enjoyment of innocent delights and recreations, to the contemplation of the works of nature, and the ways of Providence, and to the still sublimer pleasures of rational piety.

If, possessing all these benefits and advantages, external and internal, together with a mental constitution, so happily attempered, as to have been to him a perpetual fountain of cheerfulness, we can entertain a doubt that Walton was one of the happiest of men, we estimate them at a rate too low, and show ourselves ignorant of the nature of that felicity, to which it is possible, even in this life, for virtuous and good men with the blessing of God to arrive.

The foregoing biographical sketch is condensed from the life of Walton prefixed to an edition of his "Complete Angler" published in 1797 by Sir J. Hawkins, who in a remote degree (Anne Walton's, only daughter married a Hawkins) was by affinity descended from the common ancestor, figuratively, of all anglers.

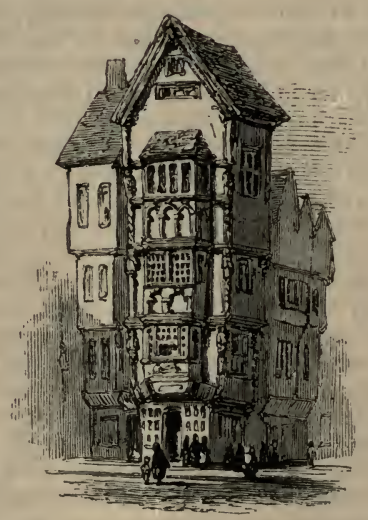

WAITON'S EOUSE. 


\title{
THE EPISTLE DEDICATORY.
}

\author{
TO THE RIGHT WORSHIPFUL
}

JOHN OFFLEY, EsQ.,

OF MADELEY MANOR, IN THE COUNTY OF STAFFORD.

\section{Mx MCOST HONOURED Firiend,}

Sir,- I have made so ill use of your former favours, as by them to be encouraged to entreat, that they may be enlarged to the patronage and proteetion of this book: and I have put on a modest confidence, that, I shall not be denied, beeause it is a discourse of fish and fishing, which you know so well, and both love and practise so much.

You are assured, though there be ignorant men of another belief, that angling is an art: and you know that art better than others; and that this truth is demonstrated by the fruits of that pleasant labour which you enjoy, when you purpose to give rest to your mind, and divest yourself of your more serious business, and (whieh is often) dedieate a day or two to this reereation.

At which time, if common Anglers should attend you, and be cye-witnesses of the suecess, not of your fortune but your skill, it would doubtless beget in them an emulation to be like you, and that emulation might beget an industrious diligence to be so; but I know it is not attainable by common eapacities. And there be now many men of great wisdom, learning, and experience, which love and practise this art, that know I speak the truth.

Sir, this pleasant curiosity of fish and fishing, of which you are so great a master has been thought worthy the pens and practices of divers in other nations, that have been reputed men of great learning and wisdom : and amongst those of this nation, I remeniber Sir Henry Wotton (a dear lover of this art) has told me, that his intentions were to write a discourse of the art, and in praise of angling; and doubtless he had done so, if death had not prevented him; the remembrance of which hath often made me sorry; for if he had lived to do it, then the unlearned angler had seen some better treatise of this art, a treatise that might have proved worthy his perusal, which, though some have undertaken, I could never yet see in English.

But mine may be thought as weak, and as unworthy of common riew; and I do here freely confess, that I should rather excuse myself, than censure others, my own discourse being liable to so many exceptions; against which you, sir, might make this one, that it ean contribute nothing to your knowledge. And lest a longer epistle may diminish your pleasure, I shall make this no longer than to add this following truth, that I an really,

$$
\begin{aligned}
& \text { Sir, } \\
& \text { Your most affectionate friend, } \\
& \text { And most humble servant, } \\
& \text { Iz. WA. }
\end{aligned}
$$




\section{Ilist of Elllustrations.}

FRONTISPIECE.

ORNAMENTAI TITLE.

ORIGINAL TITLE.

MONOGRAM, page 239.

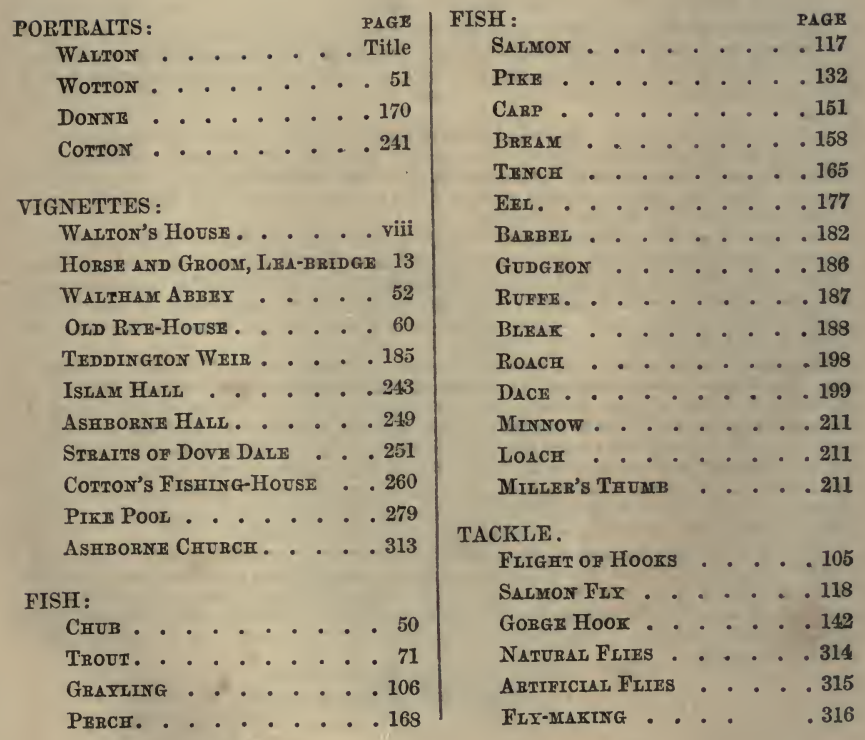


CONTENTS.

\section{PART I.}

first 理ap.

Chapter I. A Dialogue between Prscator (an Angler), Venator (a Hunter), and A ACBPs (a Falconer) $\quad . \quad$. . . . . . 13

\section{Seconช 现ap.}

II. Of the Orres, Otter-hunting, and Observations about the Habits of the Crub

\section{Thír 更an.}

III. How to fish for and cook the CHAveNDri or $\mathrm{CHUB}$. . . . 52

IV. Observations (by no means sound) of the Nature and Breeding of the Trout, and how to fish for him; the Milkmaid's Song . . 60

V. More Directions how to fish for, and how to make for the Trout an artificial Minnow and Flies . . . . . . 70

\section{fourth 㐷av.}

VI. Observations of the UMBRI or GrapuING; and Directions how to fish for him . . . . . . . . . 106

VII. Observations of the SALMoN; Directions how to fish for him . . 111

VIII. Observations of the PIKE; Directions how to fish for him . . 131

IX. Ohservations of the CARP; Directions how to fish for him . . 147

X. Observations of the BrraM ; and Directions to eateh him . $\quad .157$

XI. Observations of the TeNcH ; Advice how to angle for him . . 161

XII. Observations of the PrRCI ; Directions how to fish for him . 167

XIII. Observations of the ErL, and other Fish that want Seales; and how to fish for them . . . . . . . 172

XIV. Observations of the BARBEL; Direetions how to fish for him . $\quad .180$

XV. Observations of the GUDGEON, the RUFFE, and the BLEAK; and how to fish for them . . . . . . . . 186

XVI. Is of Nothing, or that which is Nothing worth $\quad$. . $\quad . \quad 190$

$$
\text { fiftih (last) Ilap. }
$$

XVII. Of RoACH and DACE, and how to fish for them; and of CAnis . 196

XVIII. Of the MrNaw or PenK, of the Loacr, and of the BuLl-Head or

MrLlez's Thumb . . . . . . . . . . 210 
Cripter XiX. Of several Rivers; and some Observations of Fish . . . . 213

XX. Of Fish-Ponds, and how to order them ․ . . . . . . 217

XXI. Directions for making of a Line, and for the colouring of both Rod and Line . . • • • • • • • • • . 223

The First and Sceond Days contain a Chapter, simply conversational, each.

The Third Day, two Chapters and a half on Chub and Trout Fishing. The Fourth Day begins in the middle of the Fifth Chapter, and extends to the Sixteenth Chapter, inclusive. The Fifth Day, comprising five Chanters, by no means interesting ones to the mere angler, terminates the First Part of " The Complete Angler." Piscator and Venator intended to angle for two or three days only : love of the art caused them to prolong their teaching, study, and practice of it.

\section{PART II.}

\section{fiŕrst 田an.}

Cirapter I.) A Dialogue between Piscator Junior (Cotton) and Viator (the

II. Venator of the First Part of the Book). All these Chapters

III. are initiatory, chiefly descriptive of the River Dove and other vicinous Rivers, and of Beresford . . . . . . . 213

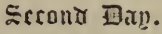

IV. Angling at the "Top," at the "Middle," and at the "Bottom" . 263

V. Of Fly-fishing and Fly-Making . . . • . . • . 264

VI. A practical Lesson on Fly-Fishing for Trout and Grayling . $\quad$. 274

VII. Lists of Artificial Flies for the Months of January, February, March, April, and May; showing also how to dib or dape with the Green-Drake or May-Fly, and how to make that famous Fly artificially . . . . . • • • • . . 281

VIII. Of the Stone-Fly; also a List of Flies for June, July, August, September, October, November, and December; with some good Remarks on the Grecn-Drake, and Stone-Fly, and on Poaching. . . . . . . . . . . . 295

\section{Thira (last) 互an.}

IX. A Short Dialogue, and a Lapse in Angling on the Part of Piscator. Viator fishes successfully by himself . . . . . . . 302

$\mathrm{X}$. Showing how Trout and Grayling are best cooked . . . . 303

XI. Teaches the Art of Angling at the Bottom with Worms, Grubs, and Cadis. . . . . . . . . . . . 305

Xli. Contains Directions touching Angling at the Middle with a Minnow for Trout, and with a Worm, Grub, or Cadis for a Grayling. Farewell between Piscator Juxior and Viatol . • • . 310 


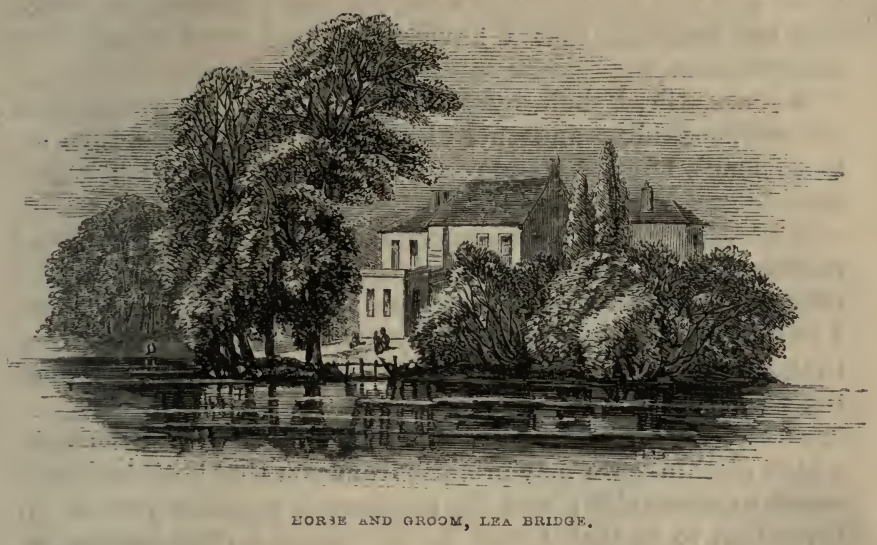

\section{THE COMPLETE ANGLER.}

\section{PART THE FIRST.}

CHA PTER I.

CONYERENCE BETWIXT AN ANGLER, A HUNTER, AND A FALCONER;

EACII COMMENDING HIS RECREATION.

\section{[ffirst \$an..]}

Piscator, Venator, Auceps.

Piscator. You are well overtaken, Gentlemen ; a good' morning to you both; I have stretched my legs up Tottenhamhill to overtake you, hoping your business may occasion you towards Ware, whither I am going this tine, fresh May morning.

VENATOR. Sir, I for my part shall almost answer your hopes ; for my purpose is to drink my morning's draught at the Thatched-house in Hoddesden, and I think not to rest till I come thither, where I have appointed a friend or two to 
meet me: but for this gentleman that you see with me, I know not how far he intends his journey; he came so lately into my company, that I have scarce had time to ask him the question.

AUCEPS. Sir, I shall, by your favour, bear you company as far as Theobald's, * and there leave you; for then I turn up to a friend's house who mews a hawk for me, which I now long to see.

VEN. Sir, we are all so happy as to have a fine, fresh, cool morning; and I hope we shall each be the happier in the other's company. And, gentlemen, that I may not lose yours, I shall either abate or amend my pace to enjoy it; knowing that, as the Italians say, "Good company in a journey makes the way to seem the shorter."

Auc. It may do so, sir, with the help of good discourse, which methinks we may promise from you that both look and speak so cheerfully; and for my part I promise you, as an invitation to it, that $I$ will be as free and open-hearted as discretion will allow me to be with strangers.

VEN. And, sir, I promise the like.

PIsc. I am right glad to hear your answers, and in confidence you speak the truth, I shall put on a boldness to ask you, sir, whether business or pleasure caused you to be so early up, and walk so fast; for this other gentleman hath declared that he is going to see a hawk that a friend mews for him.

VEN. Sir, mine is a mixture of both, a little business and more pleasure ; for I intend this day to do all my business, and then bestow another day or two in hunting the Otter, which a friend, that I go to meet, tells me is much pleasanter than any other chase whatsoever : howsoever, I mean to try it; for to-morrow morning we shall nieet a pack of Otter-dogs of noble Mr. Sadler's, upon Amwell-hill, who will be there so early that they intend to prevent [forestall] the sun-rising.

PIsc. Sir, my fortune has answered my desires, and my purpose is to bestow a day or two in helping to destroy some of those villanous vermin; for I hate them perfectly, because they love fish so well, or rather, because they destroy so much; indeed so unuch that, in my judgment, all men that keep Otter-dogs ought to have pensions from the king, to encourage

* A house built by Lord Burleigh in Herts, and by his son, an Earl of Salisbury, exchanged with James I. for Hatfield-house. 
them to destroy the very breed of those base Otters, they do so much mischief.

VEN. But what say you to the Foxes of the Nation, would not you as willingly have them destroyed? for doubtless they do as much mischief as Otters do.

PIsc. O sir, if they do, it is not so much to me and my fraternity, as those base vermin the Otters do.

Auc. Why, sir, I pray, of what fraternity are you, that you are so angry with the poor Otters?

Prsc. I am, sir, a brother of the Angle, and therefore an enemy to the Otter :* for you are to note that we Anglers all love one another, and therefore do I hate the Otter, both for my own and for their sakes who are of my brotherhood.

VEN. And I am a lover of Hounds; I have followed many a pack of dogs many a mile, and heard many merry huntsmen make sport and scoff at Anglers.

Auc. And I profess myself a Falconer, and have heard many grave serious men pity them, it is such a heavy, contemptible, dull, recreation.

Prsc. You know, gentlemen, it is an easy thing to scoff at any art or recreation ; a little wit, mixed with ill-nature, confidence, and malice, will do it; but though they often venture boldly, yet they are often caught, even in their own trap, according to that of Lucian, the father of the family of scoffers.

Lucian, well skill'd in scoffing, this hath writ,

Friend, that's your folly, which you think your wit;

This, you vent oft, void both of wit and fear,

Meaning another, when yourself you jeer.

If to this you add what Solomon says of scoffers, that "they are an abomination to mankind," let them that think

* The Otter has almost disappeared from the Lea, and is now rare in all the rivers of the Metropolitan counties. This amphibious animal is destructive to trout and small river fish; but, strange as it may appear, he proves the conservator of salmon, by destroying trout, the worst enemies of that fish. The otter cannot, in open water, catch the salmon, who is too fleet for him; but he sometimes captures that fish in shallow and confined water, more by stratagem than speed. Trout the Otter can run down. He kills them in large numbers, to the delight of the owners of salmon rivers. When salmon are in the act of spawning, they are surrounded by trout, hungering after the ova, the greater portion of which they would devour were they not beaten off by one or other of the breeding salmon. Trout, moreover, feed voraciously on salmon-fry, so that by destroying them the Otter does good service to salmon-hunting. Otter-fishing, with Otter-hounds, is very exciting sport, and is now principally confined to the midland, western, and northern counties, and to the lowlands of Scotland. The Otter packs of the Earl of Aberdeen and the Marquis of Worcester are very celebrated.-ED. 
fit scoft on, and be scoffers still ; but I account them enemies to me and to all that love virtue and angling.

And for you, that have heard many grave, serious men, pity Anglers; let me tell you, sir, there be many men that are by others taken to be serious and grave men, whom we contemn and pity. Men that are taken to be grave, because nature hath made them of a sour complexion ; money-getting men, mell that spend all their time, first in getting, and next in anxious care to keep it ; men that are condemned to be rich, and then always busy or discontented; for these poor rich men, we Anglers pity them perfectly, and stand in no need to borrow their thoughts to think ourselves so happy. No, no, sir, we enjoy a contentedness above the reach of such dispositions, and as the learned and ingenuous Montaigne sayslike himself, freely, "When my cat and I entertain each other with mutual apish tricks, as playing with a garter, who knows but that I make my cat more sport than she makes me? Shall I conclude her to be simple, that has her time to begin or refuse to play as freely as I myself have? Nay, who knows but that it is a defect of my not understanding her language (for doubtless cats talk and reason with one another), that we agree no better? And who knows but that she pities me for being no wiser than to play with her, and laughs and censures my folly for making sport for her, when we two play together?'

Thus freely speaks Montaigne concerning cats; and I hope I may take as great a liberty to blame any man, and laugh at him too, let him be never so grave, that hath not heard what Anglers can say in the justification of their art and recreation ; which I may again tell you is so full of pleasure, that we need not borrow their thoughts to make ourselves happy.

VEN. Sir, you have almost amazed me; for though I am no scoffer, yet I have, I pray let me speak it without offence, always looked upon Anglers as more patient and more simple men, than I fear I shall find you to be.

PIsc. Sir, I hope you will not judge my earnestness to be impatience : and for my simplicity, if by that you mean a harmlessness, or that simplicity which was usually found in the primitive Christians, who were, as most Anglers are, quiet men, and followers of peace; men that were so simply wise, as not to sell their consciences to buy riches, and with them vexation and a fear to die; if you mean such simple men as lived in those times when there were fewer lawyers; when men might have had a lordship safely conveyed to them in a 
piece of parchment no bigger than your hand, though several sheets will not do it safely in this wiser age; I say, sir, if you take us Anglers to be such simple men as I have spoken, then myself and those of my profession will be glad to be so understnod: but if by simplicity you meant to express a general defect in those that profess and practise the excelient art of angling, I hope in time to disabuse you, and make the contrary appear so evidently, that, if you will but have patience to hear me, I shall remove all the anticipations that discourse, or time, or prejndice, have possessed you with against that laudable and ancient art; for I know it worthy the knowledge and practice of a wise man.

But, gentlemen, though I be able to do this, I am not so unmaunerly as to engross all the discourse to myself; and, therefore, you two having declared yourselves, the one to be a lover of hawks, the other of hounds, I shall be most glad to hear what you can say in the commendation of that, recreation which each of you love and practise ; and having heard what you can say, I shall be glad to exercise your attention with what I can say concerning my own recreation and art of angling, and by this means we shall make the way to seem the shorter; and if you like my motion, I would have Mr. Falconer to begin.

Avc. Your motion is consented to with all my heart ; and to testify it, I will begin as you have clesired me.

And first, for the element that I use to trade in,-which is the air, - an element of more worth than weight_-an element that donbtless exceerls both the earth and water; for though I sometimes deal in both, yet the air is most properly mine,I and my hawks use that most, and it yields us most recreation: it stops not the high soaring of my noble, generous falcon; in it she ascends to such a height as the dull eyes of beasts and fish are not able to reach to ; their bodies are too gross for such high elevations : in the air my troops of hawks soar up on high, and when they are lost in the sight of men, then they attend upon and converse with the gods; therefore: I think my eagle is so justly styled "Jove's servant in ordinary ;" and that very falcon that I am now going to see, deserves no meaner title, for she usually in her flight endanger's herself, like the son of Dredalus, to have her wings scorched by the sun's heat, she flies so near it; but her mettle makes her careless of danger; for then she heeds nothing, but makes her nimble pinions cut the fluid air, and so makes her- 
highway over the steepest mountains and deepest rivers, and in her glorious career looks with contempt upon those high steeples and magnificent palaces which we adore and wonder at; from which height I can make her to descend by a word from my mouth (which she both knows and obeys), to accept of meat from my hand, to own me for her master, to go home with me, and be willing the next day to afford me the like recreation.

And more : this element of air which I profess to trade in, the worth of it is such, and it is of such necessity, that no creature whatsoever, not only those numerous creatures that feed on the face of the earth, but those various creatures that have their dwelling within the waters, every creature that hath life in its nostrils, stands in need of my element. The waters cannot preserve the fish without air, witness the not breaking of ice in an extreme frost :* the reason is, for that if the inspiring and expiring organ of any animal be stopped, it suddenly yields to nature, and dies. Thus necessary is air to the existence both of fish and beasts, nay, even to man himself ; the air or breath of life with which God at first inspired mankind, he, if he wants it, dies presently, becomes a sacl object to all that loved and beheld him, and in an instant turns to putrefaction.

Nay more, the very birds of the air, those that be not hawks, are both so many and so useful and pleasant to mankind, that I must not let them pass without some observations. They both feed and refresh him-feed him with their choice bodies, and refresh him with their heavenly voices. I will not undertake to mention the several kinds of fowl by which this is done-and his curious palate pleased by day, and which with their very excrements afford him a soft lodging at night - these I will pass by ; but not those little nimble musicians of the air, that warble forth their curious ditties, with which nature hath furnished them to the shame of art.

As, first, the lark, when she means to rejoice, to cheer herself and those that hear her; she then quits the earth, and sings as she ascends higher into the air, and having ended her heavenly employment, grows then mute and sad, to think

* Though deep waters may be frozen over, fish will live in them beneath the ice. In shallow waters, fish are frequently frozen to death. Fish, like certain quadrupeds - the northern bear, the marmot, and the little dormouse, frequently remain in a torpid state during winter, and only revive with renewed increase of temperature of the water, caused by rains or atmospheric influence.-ED. 
she must descend to the dull earth, which she would not touch, but for necessity.

How do the blackbird and thrassel [thrush], with their melodious voices, bid welcome to the cheerful spring, and in their fixed months warble forth such ditties as no art or instrument can reach to?

Nay, the smaller birds also do the like in their particular seasons, as, namely, the leverock, the titlark, the little linnet, and the honest robin, that loves mankind both alive and dead.

But the nightingale, another of my airy creatures, breathes such sweet loud music out of her little instrumental throat, that it might make mankind to think miracles are not ceased. He that at midnight, when the very labourer sleeps securely, should hear, as I have very often, the clear airs, the sweet descants, the natural rising and falling, the doubling and redoubling of her voice, might well be lifted above earth, and say, "Lord, what music hast thou provided for the saints in heaven, when thou affordest bad men such music on earth?"

And this makes me the less to wonder at the many aviaries in Italy, or at the great charge of Varro's aviary, the ruins of which are yet to be seen in Rome, and is still so famous there, that it is reckoned for one of those notables which men of foreign nations either record, or lay up in their memories, when they return from travel.

This for the birds of pleasure, of which very much more might be said. My next shall be of birds of political use. I think 'tis not to be doubted that swallows* have been taught to carry letters between two armies. But it is certain, that when the Turks besieged Malta or Rhodes (I now remember not which it was), pigeons are then related to carry and recarry letters. And Mr. G. Sandys, in his Travels, relates it to be done between Aleppo and Babylon. But if that be disbelieved, it is not to be doubted that the dove was sent out of the ark by Noah, to give him notice of land, when to him

* Walton's knowledge of Natural History was as superficial and as superstitious, if I may be allowed the use of the epithet, in many respects, as that of a Munster peasant or IIighland shepherd of the present day. No birds can be trained to fly to and from places. The carrier-pigeon will only fly with a message, generally written on a slip of oiled-tissue paper lapped round the leg, from a place to which the bird is taken, to its home. It will not carry a message from its home or dove-cot to a given place; it can make a return royage, but not an outuard one.-ED. 
all appeared to be sea; and the dove proved a faithful and comfortable messenger. And for the sacrifices of the law, a pair of turtle-doves or young pigeons were as well accepted as costly bulls and rams. And when God would feed the prophet Elijah after a kind of miraculous manner, he did it by ravens, who brought him meat morning and evening. Lastly, the Holy Ghost, when he descended visibly upon our Saviour, did it by assuming the shape of a dove. And to conclude this part of my discourse, pray remember these wouders were done by birds of the air, the element in which. they and I take so much pleasure.

There is also a little contemptible winged creature, an inhabitant of my aërial element, - namely, the laborious bee,- - of whose prudence, policy, and regular government of their own commonwealth, I might say much, as also of their several kinds, and how useful their honey and wax are both for meat and medicines to mankind; but I will leave them to their sweet labour, without the least disturbance, believing them to be all very busy at this very time amongst the herbs and flowers that we see nature puts forth this May morning.

And now to return to my hawks, from whom I have made too long a digression; you are to note, that thay are usually distinguished into two kinds; namely, the long-winged and the short-winged hawk: of the first kind, there be chiefly in use amongst us in this nation,

The Gerfalcon and Jerkin,

The Falcon and Tassel-gentel,

The Laner and Lanaret,

The Bockerel and Bockeret,

The Saker and Sacaret,

The Merlin and Jack Merin,

The Hobby and Jack :

There is the Stelletto of Spain,

The Blood-red Rook from Turkey,

The Waskite from Virginia :

And there is of short-winged hawks,

The Eagle and Iron,

The Goshawk and Tarcel,

The Sparhawk and Musket,

The French Pye, of two sorts. 
These are reckoned hawks of note and worth; but we have also hawks of an inferior rank,

The Stanyel, the Ringtail,

The Raven, the Buzzard,

The Forked Kite, the Bald Buzzard,

The Hen-driver, and others that I forbear to name.*

Gentlemen, if I should enlarge my discourse to the observation of the eiries, the brancher, the ramish hawk, the haggard, and the two sorts of lentners, and then treat of their several ayries, their mewings, rare order of casting, and the renovation of their feathers: their reclaiming, dieting, and then come to their rare stories of practice; I say, if I should enter into these, and many other observations that I could make, it would be much, very much pleasure to me : but lest I should break the rules of civility to you, by taking up more than the proportion of time allotted to me, I will here break off, and entreat you, Mr. Venator, to say what you are able in the commendation of hunting, to which you are so much affected; and, if time will serve, I will beg your favour for a further enlargement of some of those several heads of which I have spoken. But no more at present.

VEN. Well, sir, and I will now take my turn, and will first begin with a commendation of the Earth, as you have done most excellently of the Air; the carth being that element upon which I drive my pleasant, wholesome, hungry trade. The earth is a solid, settled element-an element most universally beneficial both to man and beast: to men who have their several recreations upon it, as horse-racing, hunting, sweet smells, pleasant walks : the earth feeds man, and all those several beasts that both feed him, and afford him recreation. What pleasure doth man take in hunting the stately stag, the generous buck, the wild boar, the cunning

* It is evident, from this list of so-called falcons, that Walton's "Auceps" was not an adept in the art of hawking. The blood-red rook, the French pye, and the raven, are not falcons at all, and were never trained to fly at winged game. Of the other birds named in the list, only three are used in hawking, viz., the gerfalcon, the goshawk, and the falcon and tassel-gentel. It may be necessary to explain the last two names. By "falcon" is meant the peregrine falcon, the best of all the tribe; and "tassel gentel" is merely the peregrine in its second or third year. The merlin and hobby are very small hawks, and will catch quails, larks, and sometimes partridges. The same may be said of the sparrow-hawk. The eagle, buzzard, hen-driver (now called hen-harrier), and kite, were never valued in hawking. In fact, these latter birds do not pursue their quarry, but pounce upon it.-ED. 
otter, the crafty fox, and the fearful hare? And if I may descend to a lower game, what pleasure is it sometimes with gins to betray the very vermin of the earth ? as, namely, the fitchet, the fulimart, the ferret, the pole-cat, the mould-warp, and the like creatures that live upon the face and within the bowels of the earth! How doth the earth bring forth herbs, flowers, and fruits, both for physic and the pleasure of mankind! and above all, to me at least, the fruitful vine, of which, when I drink moderately, it clears my brain, cheers my heart, and sharpens my wit. How could Cleopatra have feasted Mark Antony with eight wild boars roasted whole at one supper, and other meat suitable, if the earth had not been a bountiful mother? But to pass by the mighty elephant, which the earth breeds and nourisheth, and descend to the least of creatures, how doth the earth afford us a doctrinal example in the little pismire, who in the summer provides and lays up her winter provision, and teaches man to do the like! The earth feeds and carries those horses that carry us. If I would be prodigal of my time and your patience, what might not I say in commendations of the earth ? that puts limits to the proud and raging sea, and by that means preserves both man and beast, that it destroys them not, as we see it daily doth those that venture upon the sea, and are there shipwrecked, drowned, and left to feed haddocks; when we that are so wise as to keep ourselves on the earth, walk, and talk, and live, and eat, and drink, and go a hunting : of which recreation I will say a little, and then leave Mr. Piscator to the commendation of angling.

Hunting is a game for princes and noble persons; it hath been highly prized in all ages; it was one of the qualifications that Xenophon bestowed on his Cyrus, that he was a hunter of wild beasts." Hunting trains up the younger nobility to the use of manly exercises in their riper age. $t$ What more manly exercise than hunting the wild boar, the stag, the buck, the fox, or the hare? How doth it preserve health, and increase strength and activity!

* See Cyropsedia, education of Cyrus, book i. chap. 5. Cyrus, when a boy, paid a visit to his maternal grandfather, Astyages, king of the Medes, who kept all sorts of wild beasts in large parks (paradeisoi, or paradises). Here the young Persian prince hunted continually the lion, the bear, and wild boar, and in the sporting-field prepared himself for the battle-field.-ED.

+ Professor Jolin Wilson (the well-known Kit North of Blackwood) attributes the excellency of our cavalry officers to their fox-hunting education. The Duke of Wellington kept a pack of fox-hounds in Spain, and hunted when histroops were in their winter cantonments.-ED. 
And for the dogs that we use, who can commend their excellency to that height which they deserve? How perfect is the hound at smelling, who never leaves or forsakes his first scent, but follows it through so many changes and varieties of other scents, even over and in the water, and into the earth! What music doth a pack of dogs then make to any man, whose heart and ears are so happy as to be set to the tume of such instruments! How will a right greyhound fix his eye on the best buck in a herd, single him out, and follow him, and him only, through a whole herd of rascal game, and still know and then kill him! For my hounds, I know the language of them, and they know the language and meaning of one another as perfectly as we know the voices of those with whom we discourse daily.

I might enlarge myself in the commendation of hunting, and of the noble hound especially, as also of the docibleness of dogs in general ; and I might make many observations of land creatures, that for composition, order, figure, and constitution, approach nearest to the completeness and understanding of man ; especially of those creatures which Moses in the law permitted to the Jews, which have cloven hoofs, and chew the cud; which I shall forbear to name, because I will not be so uncivil to Mr. Piscator, as not to allow him a time for the commendation of angling, which he calls an art ; but doubtless it is an easy one ; and, Mr. Auceps, I doubt we shall hear a watery discourse of it, but $I$ hope it will not be a long one.

Auc. And I hope so too, though I fear it will.

Prsc. Gentlemen, let not prejudice prepossess you. I confess my discourse is like to prove suitable to my recreation, calm and quiet; we seldom take the name of God into our mouths but it is either to praise him or pray to him; if others use it vainly in the midst of their recreations, so vainly as if they meant to conjure, I must tell you that it is neither our fault nor our custom; we protest against it. But pray remember, I accuse nobody; for as I would not make a "watery discourse," so I would not put too much vinegar into it, nor would I raise the reputation of my own art by the diminution or ruin of another's.* And so much for the prologue to what I mean to say.

And now for the water, the element that I trade in. The

* Spoken not only like an angler, but like a true sportsman, who appreciates every sort of field-sport, though he gives a preference to one.-ED. 
water is the eldest daughter of the creation, the element upon which the Spirit of God did first move, the element which God commanded to bring forth living creatures abundantly ; and without which, those that inhabit the land, even all creatures that have breath in their nostrils, must suddenly return to putrefaction. Moses, the great lawgiver, and chief philosopher, skilled in all the learning of the Egyptians, who was called the friend of God, and knew the mind of the Almighty, names this element the first in the creation; this is the element upon which the Spirit of God did first move, and is the chief ingredient in the creation : many philosophers have made it to comprehend all the other elements, and most allow it the chiefest in the mixtion of all living creatures.

There be that profess to believe that all bodies are made of water, and may be reduced back again to water only: they endeavour to demonstrate it thus :

Take a willow, or any like speedy growing plant, newly rooted in a box or barrel full of earth, weigh them all together exactly when the tree begins to grow, and then weigh all togeiher after the tree is increased from its first rooting, to weigh a hundred pound weight more than when it was first rooted and weighed; and you shall find this augment of the tree to be without the diminution of one drachm weight of the earth. Hence they infer this increase of wood to be from water of rain, or from dew, and not to be from any other element. And they affirm they can reduce this wood back again to water; and they affirm also the same may be done in any animal or vegetable. And this I take to be a fair testimony of the excellency of my element of water.

The water is more productive than the earth. Nay, the earth hath no fruitfulness without showers or dews; for all the herbs and flowers and fruit are produced, and thrive by the water; and the very minerals are fed by streams that run under ground, whose natural course carries them to the tops of many high mountains, as we see by several springs breaking forth on the tops of the highest hills; and this is also witnessed by the daily trial and testimony of several miners.

Nay, the increase of those creatures that are bred and fecl in the water is not only more and more miraculous, but more advantageous to man, not only for the lengthening of his life, but for preventing of sickness, for it is observed by the most 
earned physicians, that the casting off of Lent and other fish days, which hath not only given the lie to so many learned, pious, wise founders of colleges, for which we should be ashamed, hath doubtless been the chief cause of those many putrid, shaking, intermitting agues, unto which this nation of ours is now more subject than those wiser countries that feed on herbs, salads, and plenty of fish ; of which it is observed in story, that the greatest part of the world now do.* And it may be fit to remember that Moses appointed fish to be the chief diet for the best commonwealth that ever yet was.t

And it is observable, not only that there are fish, as, namely, the whale, three times as big as the mighty elephant, that is so fierce in battle, but that the mightiest feasts have been of fish. The Romans in the height of their glory have made fish the mistress of all their entertainments ; they have had music to usher in their sturgeons, lampreys, and mullets, which they would purchase at rates rather to be wondered at than believed. He that shall view the writings of Macrobius or Varro may be confirmed and informed of this, and of the incredible value of their fish and fish-ponds.

* The Protestants certainly have east of Ient ; and many of them will cat meat on Good-Friday. The majority of English Roman Catholics eat meat four days out of the seven of the Lenten weeks. Very few fast on fish from Shrove Tuesday to Easter Sunday; and in my opinion the latter would be far more liable to agues or external influences in Easter week, than the Protestant beef-eaters. Walton frequently tries to prove too much. The inhabitants of countries that should feed on "herbs, salads, and plenty of fish," would never be so healthy and physically powerful as those whose principal food might be flesh-meat and bread. The golden eagle (falco crystatus), which feeds on flesh exclusively, is a much more powerful bird than the sea-eagle (falco cinereus), whose food is fish, though the latter is the larger bird.-ED.

† Moses did not appoint fish to be the "elief diet." He merely tells the members of the "best commonwealth" what fish it is lawful for them to eat, and what fish they should not touch. In respect to flesh-meat he does the same. Leviticus xi. 9, 10, Moses orders, "These shall ye eat of all that are in the waters: whatsoever hath fins and scales in the waters, in the seas, and in the rivers, them shall ye eat. And all that have not fins and scales in the seas, and in the rivers, of all that move in the waters, and of any living thing which is in the waters, they shall be an abomination unto you." In Deut. xiv. 5,10 , the great lawgiver repeats his fish-eating clauses: "These ye shall eat of all that are in the waters: all that have fins and scales shall ye eat : and whatsoever hath not fins and scales ye may not eat; it is unclean unto you." The modern Hebrews heed very little the edible interdicts of their progenitors. They are, in England at least, great consumers, and the very best cooks of fish without scales - of plaice, soles, turbot, cod, barbel, tench, \&c. If the sumptuary laws of Moses were observed by them, the economic luxuries of the friedfish shops would be lost to myriads of Jews and Gentilcs.-ED. 
But, gentlemen, I have almost lost myself, which I confess I may easily do in this philosophical discourse; I met with most of it very lately, and I hope, happily, in a conference with a most learned physician, Dr. Wharton, ${ }^{*}$ a dear friend, that loves both me and my art of angling. But, however, I will wade no deeper in these mysterious arguments, but pass to such observations as I can manage with more pleasure, and less fear of running into error. But I must not yet forsake the waters, by whose help we have so many known advantages.

And tirst, to pass by the miraculous cures of our known baths, how advantageous is the sea for our daily traffic, without which we could not now subsist! How does it not. only furnish us with food and physic for the bodies, but with such observations for the mind as ingenious persons would not want!

How ignorant had we been of the beauty of Florence, of the monuments, urns, and rarities that yet remain in and near unto old and new Rome, so many as it is said will take up a year's time to view, and afford to each of them but a convenient consideration! And therefore it is not to be wondered at, that so learned and devout a father as St. Jerome, after his wish to have seen Christ in the flesh, and to have heard St. Paul preach, makes his third wish, to have seen Rome in her glory; and that glory is not yet all lost, for what pleasure is it to see the monuments of Livy, the choicest of the historians ; of Tully, the best of orators ; and to see the bay-trees that now grow out of the very tomb of Virgil ! These, to any that love learning, must be pleasing. But what pleasure is it to a devout Christian to see there the humble house in which St. Paul was content to dwell, and to view the many rich statues that are made in honour of his memory! nay, to see the very place in which St. Petert and he lie buried together! These are in and near to Rome. And how

* Dr. Thomas Wharton, an eminent physician and excellent anatomist, and Gresham professor of physic. He lived in Aldersgate-street, London, and died 1673.

$\dagger$ The Protestants deny not only that St. Peter lies buried in the Vatican, as the Romish writers assert, but that he ever was at Rome. See the Fistoria Apostolica of Lud. Capellus. The sense of the Protestants on this point is expressed in the following epigram, alluding to the prænomen of Peter, Simon, and to the simony practised in that city-

"An Petrus fuerat Romæ sub judice lis est. Simonem Romæ nemo fuisse negat."-H. 
much more doth it please the pious curiosity of a Christian to see that place on which the blessed Saviour of the world was pleased to humble himself, and to take our nature upon him, and to converse with men : to see Mount Zion, Jerusalem, and the very sepulchre of our Lord Jesus? How may it beget and heighten the zeal of a Christian to see the devotions that are daily paid to him at that place! Gentlemen, lest I forget myself I will stop here and remember you, that but for my element of water, the inhabitants of this poor island must remain ignorant that such things ever were, or that any of them have yet a being.

Gentlemen, I might both enlarge and lose myself in such like arguments ; I might tell you that Almighty God is said to have spoken to a fish but never to a beast; that he hath made a whale a ship to carry, and set his prophet Jonah safe on the appointed shore. Of these I might speak, but I must in manners break off, for I see Theobald's house. I cry your mercy for being so long, and thank you for your patience.

Auc. Sir, my pardon is easily granted you : I except against nothing that you have said; nevertheless I must part with you at this park-wall, for which I am very sorry ; but I assure you, Mr. Piscator, I now part with you fill of good thoughts, not only of yourself, but your recreation. And so, gentlemen, God keep you both.

Pisc. Well now, Mr. Venator, you shall neither want time nor my attention to hear you enlarge your discourse concerning hunting.

VEN. Not I, sir: I remember you said that angling itself was of great antiquity and a perfect art, and an art not easily attained to; and you have so won upon me in your former discourse, that I am very desirous to hear what you can say farther concerning those particulars.

Pisc. Sir, I did say so : and I doubt not but if you and I did converse together but a few hours, to leave you possessed with the same high and happy thoughts that now possess me of it ; not only of the antiquity of angling, but that it deserves commendations; and that it is an art, and an art worthy the knowledge and practice of a wise man.

VEN. Pray, sir, speak of them what you think fit, for we have yet five miles to the Thatched House; during which walk, I dare promise you my patience and diligent attention shall not be wanting. And if you shall make that to appear. which you have undertaken-first that it is an art, and an 
art worth the learning, I shall heg that I may attend you a day or two a-fishing, and that I may become your scholar and be instructed in the art itself which you so much magnify.

Prsc. $\mathrm{O}$ sir, doubt not that angling is an art. Is it not an art to deceive a trout with an artificial fly? a trout! that is more sharp-sighted than any hawk you have named, and more watchful and timorous than your high-mettled merlin is bold; " and yet I doubt not to catch a brace or two tomorrow for a firiend's breakfast;-doubt not, therefore, sir, but that angling is an art, and an art worth your learning. The question is rather, whether you be capable of learning it? for angling is somewhat like poetry, men are to be born so : I mean, with inclinations to it, though both may be heightened by discourse and practice : but he that hopes to be a good angler, must not only bring an inquiring, searching, observing wit, but he must bring a large measure of hope, and patience, and a love and propensity to the art itself; but having once got and practised it, then doubt not but angling will prove to be so pleasant, that it will prove to be like virtue, a reward to itself.

VEN. Sir, I am now become so full of expectation, that I long much to have you proceed; and in the order you propose.

PIsc. Then first, for the antiquity of angling, of which I shall not say much, but only this; some say it is as ancient as Deucalion's flood: others, that Belus, who was the first inventor of godly and virtuous recreations, was the first inventor of angling; and some other's say, for former times have had their disquisitions about the antiquity of it, that Seth, one of the sons of Adam, taught it to his sons, and that by them it was derived to posterity: others say, that he left it engraven on those pillars which he erected, and trusted. to preserve the knowledge of the mathematics, music, and the rest of that precious knowledge and those useful arts which by God's appointment or allowance and his noble industry, were thereby preserved from perishing in Noah's flood.t

* Walton is evidently thinking of Acceps, the falconer so named, who parted company as they lieared Theobald's IIouse, otherwise he would not have said to Venator, the hunter with hounds and not with hawks, " your merlin." It may be taken in another sense.-ED.

+ Those that say this are very safe in their assertion, for there is no remaining evidence to contradict it. It may, however, be observed that the same has 
These, Sir, have been the opinions of severul men that have possibly endeavoured to make angling more ancient than is needful, or may well be warranted ; but for my part, I shall content myself in telling you, that angling is much more ancient than the Incarnation of our Saviour; for in the prophet Amos* mention is made of fish-hooks; and in the book of Job, which was long before the days of Amos, for that book is said to be writ by Moses, mention is made also of fish-hooks, which must imply anglers in those times.

But, my worthy friend, as I would rather prove myself a gentleman, by being learned and humble, valiant and inoffensive, virtuous and communicable, than by any fond ostentation of riches ; or, wanting those virtnes myself, boast that these were in my ancestors (and yet I grant that where a noble and ancient descent, and such merit meet in any man, it is a double dignification of that person); so if this antiquity of angling, which for my part I have not forced, shall, like an ancient family, be either an honour or an ornament to this virtuous art which I profess to love and practise, I shall be the gladder that I made an accidental mention of the antiquity of it, of which I shall say no more, but proceed to that just commendation which I think it deserves.

And for that, I shall tell you, that in ancient times a debate hath arisen, and it remains yet unresolved: whether the happiness of man in this world, doth consist more in contemplation or action?

Concerning which some have encleavoured to maintain their opinion of the first; by saying, that the nearer we mortals come to God by way of imitation, the more happy

been said in favour of many other arts; and, if I mistake not, of the hermetic science and freemasonry : concerning the former whereof $\Lambda$ shmole has the confidence to aftirm, that by means of it Adam and the fathers before the flood, as also Abraham, Moses and Solonon, wrought many wonders. See the Prolegomena to his Theatrum Chemicum Britannicum, in which there is more such nonsense and absurdity.-II.

* In the book of Amos, iv. 2, we find-" The Lord God hath sworn by His holiness, that, lo, the days shall come upon you, that He will take you away with hooks, and your posterity with fish-hooks." In Jeremiah xvi. 16, are these words: "Behold I will send for many fishers, saith the Lord, and they shall fish them; and after will I send for many hunters, and they shall hunt them from every mountain, and from every hill, and out of the holes of the rocks. Finally, in Habakkuk i. 15 it is written: "They take up all of them with the angle, they eatch them in their net, and gather them in their drag," etc. Angling and hunting are unquestionably the most primitive of field sports. Necessity as well as pleasure led to the pursuit of bird, beast, and fish. -ED. 
we are. And they say that God enjoys himself only, by a contemplation of his own infiniteness, eternity, power, and goodness, and the like. And upon this ground, many cloisteral men of great learning and devotion, prefer contemplation before action. And many of the fathers seem to approve this opinion, as may appear in their commentaries upon the words of our Saviour to Martha, LukE x. 41, 42.

And on the contrary, there want not men of equal authority and credit, that prefer action to be the more excellent; as namely, experiments in physic, and the application of it both for the ease and prolongation of man's life; by which each man is enabled to act and do good to others, either to serve his country, or do good to particular persons. And they say also that action is doctrinal, and teaches both art and virtue, and is a maintainer of human society; and for these, and other like reasons, to be preferred before contemplation.

Concerning which two opinions, I shall forbear to add a third, by declaring my own; and rest myself contented in telling you, my very worthy friend, that both these meet together, and do not properly belong to the most honest, ingenious, quiet, and harmless art of angling.

And first, I shall tell you what some have observed, and I have found it to be a real truth, that the very sitting by the river's side is not only the quietest and fittest place for contemplation, but will invite an angler to it: and this seems to be maintained by the learned Peter Du Moulin,* who in his discourse of the fulfilling of prophecies, observes, that when God intended to reveal any future events or high notions to his prophets, he then carried them either to the deserts or the sea-shore, that having so separated them from amidst the press of people and business, and the cares of the world, he might settle their minds in a quiet repose, and there make them fit for revelation.

And this seems also to be intimated by the Children of Israel (Psal. cxxxvii.), t who having in a sad condition banished all mirth and music from their pensive hearts, and having hung up their then mute harps upon the willow-trees grow-

\footnotetext{
* An ancient prebendary of Canterbury, and author of several pieces in the Romish controversy.- $\mathrm{H}$.

$\dagger$ " By the rivers of Babylon, there we sat down, yea, we wept, when we remembered Zion. We hanged our harps upon the willows in the midst thereof." (Psalm cxxxvii. 1, 2.)
} 
ing by the rivers of Babylon, sat down upon these banks bemoaning the ruins of Sion, and contemplating their own sad condition.

And an ingenious Spaniard says, that "rivers and the inhabitants of the watery element were made for wise men to contemplate and fools to pass by without consideration." And though I will not rank myself in the number of the first, yet give me leave to free myself from the last, by offering to your a short contemplation, first of rivers and then of fish; concerning which I doubt not but to give you many observations that will appear very considerable: I am sure they have appeared so to me, and made many an hour to pass away more pleasantly, as I have sat quietly on a flowery bank by a calm river, and contemplated what I shall now relate to you.

And first, concerning rivers : there be so many wonders reported and written of them, and of the several creatures that be bred and live in them; and those by authors of so good credit, that we need not to deny them an historical faith.

As namely of a river in Epirus, that puts out any lighted torch, and kindles any torch that was not lighted. Some waters being drank cause madness, some drunkenness, and some laughter to death. The river Selarus in a few hours turns a rod or wand to stone; and our Camden mentions the like in England, and the like in Lochmere in Ireland. There is also a river in Arabia, of which all the sheep that drink thereof have their wool turned into a vermilion colour. And one of no less credit than Aristotle, tells us of a merry river, the river Elusina, that dances at the noise of music, for with music it buibbles, dances, and grows sandy, and so continues till the music ceases, but then it presently returns to its wonted calmness and clearness. And Camden tells us of a well near to Kirby in Westmoreland, that ebbs and flows several times every day : and he tells us of a river in Surrey, it is called Mole, that after it has run several miles, being opposed by hills, finds or makes itself a way under ground, and breaks out again so far off, that the inhabitants thereabout boast, as the Spaniards do of their river Anus, that they feed divers flocks of sheep upon a bridge. And lastly, for I would not tire your patience, one of no less authority than Josephus, that learned Jew, tells us of a river in Judea that runs swiftly all the six days of the week, and stands still and rests all their sabbath. 
But I will lay aside my discourse of rivers, and tell you some things of the monsters, or fish, call them what you will, that they breed and feed in them. Pliny, the philosopher, says, in the third chapter of his ninth book, that in the Indian . Sea, the fish called balcena or whirlpool, is so long and broad as to take up more in length and breadth than two acres of ground ; and of other fish of two hundred cubits long; and that, in the river Ganges, there be eels of thirty feet long. He says there, that these monsters appear in the sea only when tempestuous winds oppose the torrents of water falling from the rocks into it, and so turning what lay at the bottom to be seen on the water's top. And he says, that the people of Cadara, an island near this place, make the timber for their houses of those fish-bones. He there tells us, that there are sometimes a thousand of these great eels found wrapt or interwoven together. He tells us there, that it appears that dolphins love music, and will come when called for, by some men or boys that know, and use to feed them; and that they can swim as swift as an arrow can be shot out of a bow; and much of this is spoken concerning the dolphin, and other fish, as may be found also in the learned Dr. Casaubon's " Discourse of Credulity and Incredulity," printed by him about the year 1670.*

I know, we islanders are averse to the belief of these wonders; but there be so many strange creatures to be now seen, many collected by John 'Tradescant, $\uparrow$ and others added

* Nothing can testify more strongly the credulity of Walton, than the ridiculous statements made in this paragraph and that which precedes it, touching the character of rivers and the alleged Animalia they produce. The modern reader will not place the slighest "historical faith" in them.-ED.

+ There wcre, it seems, three of the Tradescants-grandfather, father, and son; the son is the person here meant; the two former were gardeners to Queen Elizabeth, and the latter to King Charles I. They were all great botanists, and collectors of natural and other curiosities, and dwelt at South Lambeth in Surrey; and, dying there, were buried in Iambeth churchyard. Mr. Ashmole contracted an acquaintance with the last of them, and together with his wife boarded at his house for a summer, during which Ashmole agreed for the purchase of 'Tradescant's collection, and the same was conveyed to him by a deed of gift from Tradescant and his wife. Tradescant soon after died, and Ashmole was obliged to file a bill in the Court of Chancery for the delivery of the curiosities, and succeeded in his suit. Mrs. Tradescant, shortly after the pronouncing the decree, was found drowned in her pond. This collection, with what additions he afterwards made to it, Mr. Ashmole gave to the University of Oxford, and so became the founder of the $\Lambda$ shmolean Museum. $\Lambda$ monument for all the three Tradescants, very curiously ornamented with sculptures, is to be seen in Lambeth churchyard. The Tradescants were tlie first collectors of natural curiosities in this kingdom, and Aslimole and Sir Hans Sloane were the second.-H. 
by my friend Elias Ashmole, Esq., who now keeps them carefully and methodically at his house near to Lambeth near London, as may get some belief of some of the other wonders I mentioned. I will tell you some of the wonders that you may now see, and not till then believe, unless you think fit.

You may see the hog-fish, the dog-fish, the dolphin, the coney-fish, the parrot-fish, the shark, the poison-fish, sword-fish, and not only other incredible fish, but you may there see the salamander, several sorts of barnacles, and Solan geese, the bird of Paradise, such sorts of snakes, and such birds'-nests, and of so various forms, and so wonderfully made, as may beget wonder and amusement in any beholder: and so many hundred of other rarities in that collection, as will make the other wonders I spake of the less incredible ; for you may note, that the waters are nature's store-house, in which she locks up her wonders.

But, sir, lest this discourse may seem tedious, I shall give it a sweet conclusion out of that holy poet Mr. George Herbert his divine "Contemplation on God's Providence."

Lord, who hath praise enough ; nay, who hath any?

None can express thy works but he that knows them

And none can know thy works, they are so many,

And so complete, but only he that owes them.

We all acknowledge both thy power and love

To be exact, transcendent, and divine ;

Who dost so strongly and so sweetly move,

Whilst all things have their end, yet none but thine.

Wherefore, most sacred Spirit, I here present,

For me, and all my fellows, praise to thee;

And just it is that I should pay the rent,

Because the benefit accrues to me.

And as concerning fish, in that psalm (Psalm civ.), wherein, for height of poetry and wonders, the prophet David seems even to exceed himself; how doth he there express himself in choice metaphors, even to the amazement of a contemplative reader, concerning the sea, the rivers, and the fish therein contained! And the great naturalist, Pliny, says, "that nature's great and wonderful power is more demonstrated in the sea than on the land." And this may appear by the numerous and various creatures inhabiting both in and about 
that element; as to the readers of Gesner,* Rondeletius, + Pliny, Ausonius, $\ddagger$ Aristotle, and others, may be demonstrated. But I will sweeten this discourse also out of a contemplation in divine Du Bartas, $\$$ (in the fifth day) who says :-

God quicken'd in the sea, and in the rivers, So many fishes of so many features,

That in the waters we may see all creatures, Even all that on the earth are to be found, As if the world were in deep waters drown'd. For seas-as well as skies-have sun, moon, stars ; As well as air-swallows, rooks, and stares ; As well as earth-vines, roses, nettles, melons, Mushrooms, pinks, gilliflowers, and many millions Of other plants, more rare, more strange than these, As very fishes, living in the seas ; As also rams, calves, horses, hares, and hogs, Wolves, urchins, lions, elephants, and dogs ; Yea, men and maids; and, which I most admire, The mitred bishop and the cowled friar ; Of which, examples, but a few years since,

Were shown the Norway and Polonian Prince.

These seem to be wonders, but have had so many confirmations from men of learning and credit, that you need not doubt them ; nor are the number, nor the various shapes of fishes, more strange or more fit for contemplation, than their different natures, inclinations, and actions; concerning which I shall beg your patient ear a little longer.

The cuttle-fish will cast a long gut out of her throat, which, like as an angler doth his line, she sendeth forth and pulleth in again at her pleasure, according as she sees some little fish come near to her ; and the cuttle-fish, being then hid in the gravel, lets the smaller tish nibble and bite the end

* Conrad Gesner, an eminent physician and naturalist, was born at Zurich, in 1516. His skill in botany and natural history was such as procured him the appellation of the Pliny of Germany; and Beza, who knew him, scruples not to assert, that he concentred in himself the learning of Pliny and Varro. He died in 1565 .

† Guillaume Rondelet, an eminent physician, born at Montpelier, in Languedoc, in 1507 . He wrote several books, and a treatise De P'iscibus MIarinis, where all that Walton has taken from him is to be found. He died very poor, of a surfeit occasioned by eating of figs to excess, in 1566 .

$\ddagger$ Decius Ausonius, a native of Bordeaux, was a Latin poet, consul of Rome, and preceptor to the Emperor Gratian. He died about 390.

$\$$ Guillaume de Saluste, Sieur de Bartas, was a poet of great reputation in Walton's time. He wrote, in French, a poem called "Divine Weeks and Works," from whence the passage in the text and many others cited in this work are extracted. This, with his other delightful works, was translated into English by Joshua Sylrester.-H. 
of it, at which time she by little and little draws the smaller fish so near to her, that she may leap upon her, and then catches and devours her: and for this reason some have called this fish the sea-angler.

And there is a fish called a hermit, that at a certain age gets into a dead fish's shell, and like a hermit dwells there alone, studying the wind and weather, and so turns her shell, that she makes it defend her from the injuries that they would bring upon her.

There is also a fish called, by Aslian, in his ninth book of Living Creatures, chap. 16, the Adonis, or darling of the sea; so called because it is a loving and innocent fish, a fish that hurts nothing that hath life, and is at peace with all the numerous inhabitants of that vast watery element: and truly I think most anglers are so disposed to most of mankind.

And there are also lustful and chaste fishes, of which I shall give you examples.

And first Du Bartas says of a fish called the sargus ; which because none can express it better than he does, I shall give you in his own words; supposing it shall not have the less credit for being in verse ; for he hath gathered this and other observations out of authors that have been great and industrious searchers into the secrets of natire.

The adulterous sargus doth not only change

Wives every day, in the deep streams, but, strange,

As if the honey of sea-love delight

Could not suffice his raging appetite,

Goes courting she-goats on the grassy shore,

Horning their husbands that had horns before.

And the same author writes concerning the cantharus that which you shall also hear in his own words !-

But, contrary, the constant cantharus

Is ever constant to his faithful spouse ;

In nuptial duties spending his chaste life;

Never loves any but his own dear wife.

Sir, but a little longer, and I have done.

VEN. Sir, take what liberty you think fit, for your discourse seems to be music, and charms me to an attention.

PISC. Why then, sir, I will take a liberty to tell, or rather to remember you what is said of turtle-doves : first, that they silently plight their troth, and marry; and that then the survivor scorns, as the Thracian women are said to do, to outlive his or her mate, and this is taken for a truth; and if 
the survivor shall ever couple with another, then not only the living but the dead, be it either the he or the she, is clenied the name and honour of a true turtle-dove.

And to parallel this land-rarity, and teach mankind moral faithfulness, and to condemn those that talk of religion, and yet come short of the moral faith of fish and fowl ; men that violate the law affirmed by St. Paul, Rom. ii. 14, 15, to be writ in their hearts, and which he says shall at the last day condemn and leave them without excuse; I pray hearken to what Du Bartas sings, for the hearing of such conjugal faithfulness will be music to all chaste ears, and therefore I pray hearken to what $\mathrm{Du}$ Bartas sings of the mullet.

But for chaste love the Nullet hath no peer;

For if the fisher hath surprised her pheer,

As mad with woe to shore she followeth,

Prest to consort him both in life and deatl..*

On the contrary, what shall I say of the house-cock, which treads any hen, aud then, contrary to the swan, the partridge, and pigeon, takes no care to hatch, to feed or to cherish his own brood, but is senseless, though they perish.

And it is considerable that the hen, which, because she also takes any cock, expects it not, who is sure the chickens be her own, hath by a moral impression her care and affection to her own brood more than doubled, even to such a height that our Saviour, in expressing his love to Jerusalem, Matt. xxiii. 37, qrotes her for an example of tender affection; as his Father had done Job for a pattern of patience.

And to parallel this cock, there be divers fishes that cast their spawn on flags or stones, and then leave it uncovered and exposed to become a prey and be devoured by vermin, or other fishes; but other fishes, as namely the barbel, take such care for the preservation of their seed, that unlike to the cock or the cuckov, they mutually labour, both the spawner and the melter, to cover the spawn with sand or watch it, + or hide

* All that Walton writes about the habits of fish, from the paragraph beginning, "The cuttle-tish," down to this point. has no foundation in fact. It deserves, however, the compliment paid to it by Venator-" Your discourse seems to be music, and charms me to an attention."-ED.

$\dagger$ No river-fish ever watches its spawn or ova after deposition. When the ova are deposited by the female, and impregnated by the male fish, and eovered in by a superstructure of any substance, they are abandoned by the parents, and left to be vivified by the chemical action of water, sun, and atmosphere. -Ev. 
it in some secret place, unfrequented by vermin or any fish but themselves.

Sir, these examples may to you and others seem strange, but they are testified, some by Aristotle, some by Pliny, some by Gesner, and by many others of credit; and are believed and known by divers both of wisdom and experience, to be a truth ; and indeed are, as I said at the beginning, fit for the contemplation of a most serious and a most pious man. And doubtless this made the prophet David say, "They that occupy themselves in deep waters see the wonderful works of God :" indeed such wonders and pleasures too, as the land affords not.

And that they be fit for the contemplation of the most prudent and pious and peaceable men, seems to be testified by the practice of so many devout and contemplative men, as the patriarchs and prophets of old; and of the apostles of our Saviour in our latter times, of which twelve, we are sure he chose four that were simple fishermen, whom he inspired and sent to publish his blessed will to the Gentiles ; and inspired them also with a power to speak all languages, and by their powerful eloquence to beget faith in the unbelieving Jews; and themselves to suffer for that Saviour whom their forefathers and they had crucified; and, in their sufferings, to preach freedom from the encumbrances of the law, and a new way to everlasting life: this was the employment of these happy fishermen. Concerning which choice some have made these observations.

First, That he never reproved these for their employment or calling as he did scribes and the money-changers. And secondly, he found that the hearts of such men by nature were fitted for contemplation and quietness; men of mild, and sweet, and peaceable spirits, as indeed most anglers are : these men our blessed Saviour, who is observed to love to plant grace in good natures, though indeed nothing be too hard for him; yet these men he chose to call from their irreprovable employment of fishing, and gave them grace to be his disciples, and to follow him and do wonders. I say four of twelve.

And it is observable, that it was our Saviour's will, that these our four fishermen should have a priority of nomination in the catalogue of his twelve apostles, Matt. x. 2. Acts i. 13; as namely, first, St. Peter, St. Andrew, St. James, and St. John, and then the rest in their order. 
And it is yet more observable, that when our blessed Saviour went up into the mount, when he left the rest of his disciples and chose only three to bear him company at his transfiguration, that those three were all fishermen. And it is to be believed, that all the other apostles, after they betook themselves to follow Christ, betook themselves to be fishermen too ; for it is certain, that the greater number of them were found together fishing by Jesus after his Resurrection, as it is recorded in the 21st chapter of St. John's Gospel, ver. 3 and 4.

And since I have your promise to hear me with patience, I will take the liberty to look back upon an observation that hath been made by an ingenious and learned man, who observes, that God hath been pleased to allow those, whom he himself hath appointed to write his holy will in holy writ, yet, to express his will in such metaphors as their former affections or practice had inclined them to; and he brings Solomon for an example, who before his conversion was remarkably carnally amorous ; and after, by God's appointment, wrote that spiritual dialogue, or holy amorous love-song, the Canticles, betwixt God and his church; in which he says, his beloved had eyes like the fish-pools of Heshbon.

And if this hold in reason, as I see none to the contrary, then it may be probably concluded, that Moses, who I told you before writ the book of Job, and the prophet Amos, who was a shepherd, were both anglers ; for you shall, in all the Old Testament find fish-hooks, I think, but twice mentioned : namely, by meek Moses, the friend of God, and by the humble prophet Amos. Concerning which last, namely, the prophet Amos, I shall make but this observation; that he that shall read the humble, lowly, plain style of that prophet, and compare it with the high, glorious, eloquent style of the prophet Isaiah (though they both be equally true), may easily believe Amos to be, not only a shepherd, but a good-natured, plain fisherman. Which I do the rather believe, by comparing the affectionate, loving, lowly, humble, epistles of St. Peter, St, James, and St. John, whom we know were all fishers, with the glorious language and high metaphors of St. Paul, whom we may believe was not.

And for the lawfulness of fishing: it may very well be maintained by our Saviour's bidding St. Peter cast his hook into the water and catch a fish, for money to pay tribute to Cæsar. 
And let me tell you that angling is of high esteem and much use in other nations. He that reads the voyages of Ferdinand Mendez Pinto," shall find that there he declares to have found a king and several priests a-fishing.

And he that reads Plutarch shall find that angling was not contemptible in the days of Mark Anthony and Cleopatra, and that they, in the midst of their wonderful glory, used angling as a principal recreation.t And let me tell you, that in the Scripture angling is always taken in the best sense, and that

* A traveller so noted for his mendacity, that to call any narrator of travels a " Mendez I'into," is an insult.-Ev.

+ I must here so far differ from my author, as to say, that if angling was not contemptible in the days of Mark Antony and Cleopatra, that illustrious prostitute endearoured to make it so. The fact related by Plutarch is the following :-

"It would be very tedious and trifling to recount all his follies; but his fishing must not be forgot. He went out one day to angle with Cleopatra; and being so unfortunate as to catch nothing in the presence of his mistress, he was very much vexed, and gave seeret orders to the fishermen to dive under water, and put fishes that had been fresh taken upon his hook. After he had drawn up two or three, Cleopatra perceived the trick; she pretended, however, to be surprised at his good fortune and dexterity, told it to all her friends, and invited them to come and see him fish the next day. Accordingly, a very large company went out in the fishing vessels; and as soon as Antony had let down his line, she commanded one of her servants to be beforehand with Antony's, and, diving into the water, to fix upon his hook a salted fish, one of those which were brought from the Euxine Sea."

The story here told affords matter of serious reflection. Behold here two persons of the highest rank, who had exhausted all the sources of sensual delight-their appetites palled, and every gratification rendered tastelessstooping to partake of the recreations of the meaner sort; and of tyrants and persecutors of their fellow-ereatures, to become the deceivers of silly fish and of each other. Doubtless we may suppose, that long before the tragical end which they severally made of a profligate and wieked life, they were grown tired and sick of the world, and had frequent oceasion to exclaim-and that with greater reason than their predecessor in worldly glory-that all the pomp and splendour of dominion, all the power and authority resulting from regal grandeur, all ambitious enterprises, all merely human projects, pursuits, and pleasures, without a tranquil and composed mind, such as God vouchsafes only to the meek and humble, are vanity and vexation of spirit.- $\mathrm{H}$.

[Shakspeare, no doubt, read the above passage from Plutarch ; for in his play of Anthony and Cleopatra we find the following verses:-

"Cleopatra.-Give me mine angle. We'll to the river; there,

Iy music playing far off, I will betray

Tawny-finned fishes; my bended hook shall pierce

Their slimy jaws; and as I clraw them up,

I'll think them every one an Antony,

And say, ' $\mathbf{A h}$, ha ! you're caught.'

Charmian.- 'Twas merry, when

You wager'd on your angling; when your diver

Did hang a salt-fish on his hook, which he

With fervency drew up."

Act II., Scene 5.] 
though hunting may be sometimes so taken, yet it is but seldom to be so understood. And let me add this more, he that views the ancient ecclesiastical canons, shall find hunting to be forbidden to churchmen, as being a turbulent, toilsome, perplexing recreation; and shall find angling allowed to clergymen, as being a harmless recreation-a recreation that invites them to contemplation and quietness.

I might here enlarge myself by telling you what commendations our learned Perkins bestows on angling: and how dear a lover, and great a practiser of it our learned Doctor Whittaker was, as indeed many others of great learning have been. But I will content myself with two memorable men, that lived near to our own time, whom I also take to have been ornaments to the art of angling.

The first, is Doctor Nowel, sometime Dean of the Cathedral Church of St. Paul's in London, where his monument stands yet undefaced : a man that in the reformation of Queen Elizabeth, not that of Henry VIII., was so noted for his meek spirit, deep learning, prudence, and piety, that the then Parliament and Convocation both, chose, enjoined, and trusted him to be the man to make a catechism for public use, such a one as should stand as a rule for faith and manners to their posterity. And the good old man, though he was very learned, yet knowing that God leads us not to Heaven by many nor by hard questions, like an honest angler, made that good, plain, unperplexed catechism, which is printed with our good old service-book.* I say, this good old man was a dear lover and constant practiser of angling, as any age can produce: and his custom was to spend, besides his fixed hours of prayer (those hours which, by command of the church, were enjoined. the clergy, and voluntarily dedicated to devotion by many primitive Christians); I say, beside those hours, this good man was observed to spend a tenth part of his time in angling; and also, for I have conversed with those which have conversed with him, to bestow a tenth part of his revenue, and usually all his fish, amongst the poor that inhabited near to those rivers in which it was caught ; saying often, "that charity gave life to religion :" and, at his return to his house, would praise God he had spent that day free from worldly trouble;

* The Catechism bound up with the Book of Common Prayer, is not that compiled by Dr. Nowel. He drew up at the request of Mr. Secretary Cecil. (temp. Eliz.), a larger Catechism, which was sanctioned by Convocation, and. not by Parliament, in 1562 . 
both harmlessly, and in recreation that became a churchman. And this good man was well content, if not desirous, that posterity should know he was an angler; as may appear by his picture, now to be seen, and carefully kept, in Brazen-nose College; to which he was a liberal benefactor. In which picture he was drawn, leaning on a desk, with his Bible before him, and on one hand of him his lines, hooks, and other tackling lying in a round ; and on his other hand are his anglerods of several sorts: and by them this is written, "'That he died 13 Feb. 1601, being aged $9 \tilde{5}$ years, 44 of which he had been Dean of St. Paul's Church ; and that his age had neither impaired his hearing, nor dimmed his eyes, nor weakened his memory, nor made any of the faculties of his mind weak or useless." "Tis said, that angling and temperance* were great causes of these blessings, and I wish the like to all that imitate him, and love the memory of so good a man.

My next and last example, shall be that under-valuer of money; the late provost of Eton College, Sir Henry Wotton ta man with whom I have often fished and conversed, a man whose foreign employments in the service of this nation, and whose experience, learning, wit, and cheerfulness, made his company to be esteemed one of the delights of mankind: this man, whose very approbation of angling were sufficient to convince any modest censurer of it, this man was also a most dear lover, and a frequent practiser of the art of augling ; of which he would say, "'Twas an employment for his idle time, which was then not idly spent:" for angling was, "after tedious study, a rest to his mind, a cheerer of his spirits, a diverter of sadness, a calmer of unquiet thoughts, a moderator of passions, a procurer of contentedness :" and "that it begat habits of peace and patience in those that professed and practised it." Indeed, my friend, you will find angling to be like the virtue of humility, which has a calmness of spirit, and a world of

* It would appear, that though reputed temperate, he was by no means a teetotaller; for Sir J. I Iawkins says, "that Fuller, in his 'Worthies,' Lancashire, p. 115 , has thought it worth recording of this pious and learned divine, and that in language so very quaint as to be but just intelligible, that he was accustomed to fish in the Thames; and having one day left his bottle of ale in the grass, on the bank of the river, he found it some days after, no bottle, but a gun, such the sound at the opening thereof. And hence, with what degree of sagacity, let the reader determine, he secms to derive the original of bottled ale in England."

† See his Life by Walton, in First Part of "Universal Library," section "Biography," published by Messrs. Ingram, Cooke, and Co., 227, Strand, 1853. 
other blessings attending upon it. Sir, this was the saying of that learned man.

And I do easily believe, that peace and patience, and a calm content, did cohabit in the cheerful heart of Sir Henry Wotton; because I know that when he was beyond seventy years of age, he made this description of a part of the present pleasure that possessed him, as he sat quietly in a summer's evening, on a bank a-fishing. It is a description of the spring; which because it glided as soft and sweetly from his pen, as that river does at this time, by which it was then made, I shall repeat it unto you :-

\footnotetext{
This day dame Nature seem'd in love;

The lusty sup began to move ;

Fresh juice did stir th' embracing vines;

And birds had drawn their valentines.

The jealous trout, that low did lie,

Rose at a well-dissembled fly ;

There stood my friend, with patient skill,

Attending of his trembling quill ;

Already were the eaves possess'd

With the swift pilgrim's daubèd nest ;

The groves already did rejoice

In Philomel's triumphing voice,

The showers were short, the weather mild,

The morning fresh, the evening smiled.

Joan takes her neat-rubbed pail, and now

She trips to milk the sand-red cow ;

Where, for some sturdy foot-ball swain,

Joan strokes a syllabub or twain.

The fields and gardens were beset

With tulip, crocus, violet;

$\Lambda$ nd now, though late, the modest rose

Did more than half a blush disclose.

Thus all looks gay and full of cheer,

To welcome the new-liveried year.
}

These were the thoughts that then possessed the undisturbed mind of Sir Henry Wotton. Will you hear the wish of another angler, and the commendation of his happy life, which he also sings in verse ;-viz., Jo. Davors, Esq.:-

Let me live harmlessly ; and near the brink Of Trent or Avon have a dwelling-place,

Where I may see my quill or cork down sink

With eager bite of perch, or bleak, or dace ;

And on the world and my Creator think :

Whilst some men strive ill-gotten goods t' embrace,

And others spend their time in base excess

Of wine, or worse, in war and wantonness. 
Let them that list, these pastimes still pursue, And on such pleasing fancies feed their fill;

So $I$ the fields and ineadows green may view, And daiiy by fresh rivers walk at will,

Among the daisies and the violets blue, Red hyacinth and yellow daffodil,

Purple narcissus like the morning rays, Pale gander-grass, and azure culverkeys.

I count it higher pleasure to behold The stately compass of the lofty sky ;

And in the midst thereof, like burning gold, T'he flaming chariot of the world's great eye ;

The watery clouds that, in the air up-roll'd, With sundry kinds of painted colours fly;

And fair Aurora, lifting up her head,

Still blushing, rise from old Tithonus' bed.

The hills and mountains raised from the plains, The plains extended level with the ground;

The grounds divided into sundry veins, 'The veins enclos'd with rivers running round; These rivers making way through nature's chains

With headlong course into the sea profound;

The raging sea, beneath the valleys low,

Where lakes and rills and rivulets do flow.

The lofty woods, the forests wide and long,

Adorn'd with leaves and branches fresh and green,

In whose cool bowers the birds, with many a song, Do welcome with their choir the summer's queen ;

The meadows fair, where Flora's gifts among

Are intermix'd, with verdant grass between;

The silver-scaléd fish that softly swim

Within the sweet brook's crystal watery stream.

All these, and many more of His creation

That made the heavens, the angler oft doth see ;

Taking therein no little delectation,

To think how strange, how wonderful they be!

Framing thereof an inward contemplation

To set his heart from other fancies free ;

And whilst he looks on these with joyful eye,

His mind is wrapt above the starry sky.

Sir, I am glad my memory has not lost these last verses, because they are somewhat more pleasant and more suitable to May-day than my harsh discourse. And I am glad your patience hath held out so long, as to hear them and me; for both together liave brought uswithin the sight of the Thatched House. And I must be your debtor, if you think it worth your attention, for the rest of my promised discourse, till some other opportunity; and a like time of leisure. 
VEN. Sir, you have angled me on with much pleasure to the Thatched House ; and I now find your words true, "that good company makes the way seem short;" for trust me, sir, I thought we had wanted three miles of this house, till you shewed it me. But now we are at it, we'll turn into it, and refresh ourselves with a cup of drink, and a little rest.

Pisc. Most gladly, sir, and we'll drink a civil cup to all the otter-hunters that are to meet you to-morrow.

VEx. That we will, sir, and to all the lovers of angling, of which number I am now willing to be one myself : for, by the help of your good discourse and company, I have put on new thoughts both of the art of angling, and of all that profess it : and if you will but meet me to-morrow, at the time and place appointed, and bestow one day with me and my friends in hunting the otter, I will dedicate the next two days to wait upon you, and we two will for that time do nothing but angle, and talk of fish and fishing.

PIsc. 'Tis a match, sir ; I'll not fail you, God willing, to be at Amwell-hill to-morrow morning before sun-rising.

[NOTE.-With the first chapter, the first day, passed in peripatetic conversation, ends. It contains nothing practical, but is chiefly occupied in the praise of hawking by Auceps, of hunting by Venator, and of angling by Piscator- "Old Izaak" himself. Of course he has the best of the dissertations, and makes of Venator a steady pupil. Auceps the falconer, seems too wild a fellow to settle down to the quiet amusement of angling.-ED.]

\section{CHAPTER II. \\ OBSERVATIONS OF THE OTTER AND CHUB.}

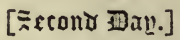

VEN. My friend Piscator, you have kept time with my thoughts, for the sun is just rising, and I myself just now. come to this place, and the dogs have just now put down an otter. Look down at the bottom of the hill there in that meadow, checquered with water-lilies and lady-smocks; there you may see what work they make: look! look! you may see all busy, men and dogs, dogs and men all busy. 
PIsc. Sir, I am right glad to meet you, and glad to have so fair an entrance into this day's sport, and glad to see so many dogs and more men all in pursuit of the otter. Let us compliment no longer, but join unto them. Come, honest Venator, let us be gone, let us make haste; I long to be doing; no reasonable lhedge or ditch shall hold me.

VEN. Gentleman-huntsman, where found you this otter?

Hunt. Marry, sir, we found her a mile from this place, a-fishing. She has this morning eaten the greatest part of this trout; she has only left this much of it as you see, and was fishing for more; when we came we found her just at it; but we were here very early, we were here an hour before sunrise, and have given her no rest since we came ; sure, she will hardly escape all these dogs and men. I am to have the skin, if we kill her.

VEN. Why, sir, what is the skin worth?

Hunt. It is worth ten shillings to make gloves; the gloves of an otter are the best fortification for your hands that can be thought on against wet weather.

PIsc. I pray, honest huntsman, let me ask you a pleasant question; do you hunt a beast or a fish ?

Hunt. Sir, it is not in my power to resolve you ; I leave it to be resolved by the college of Carthusians, who have made vows never to eat flesh. But I have heard the question hath been debated among many great clerks, and they seem to differ about it ; yet most agree that her tail is fish ; and if her body be fish too, then I may say that a fish will walk upon land ; for an otter does so, sometimes, five or six or ten miles in a night, to catch for her young ones, or to glut herself with fish. And I can tell you that pigeons will fly forty miles for a breakfast; but, sir, I am sure the otter devours much fish, and kills and spoils much more than he eats. And I can tell you that this dog-fisher, for so the Latins call him, can smell a fish in the water a hundred yards from him: Gesner says much farther; and that his stones are good against the falling sickness; and that there is an herb, benione, which being hung in a linen cloth, near a fish pond, or any haunt that he uses, makes him to avoid the place; which proves he smells both by water and land ; and I can tell you there is brave hunting this water-dog in Cornwall, where there have been so many, that our learned Camden says, there is a river called Ottersey, which was so 
named, by reason of the abundance of otters that bred and fed in it.*

And thus much for my knowledge of the otter, which you may now see above water at vent, and the dogs close with him; I now see he will not last long, follow therefore my masters, follow, for Sweetlips was like to have him at this last vent. $\uparrow$

Ven. Oh me! all the horse are got over the river, what shall we do now? Shall we follow them over the water?

Hunt. No, sir, no, be not so eager ; stay a little and follow me, for both they and the dogs will be suddenly on this side again I warrant you ; and the otter too, it may be : now have at him with Kilbuck, for he vents again.

VEN. Marry so he does, for look he vents in that corner. Now, now Ringwood has him : now he's gone again, and has bit the poor dog. Now Sweetlips has her; hold her, Sweetlips! now all the dogs have her, some above and some under water ; but now, now she's tired, and past losing : come bring her to me, Sweetlips. Look, 'tis a bitch otter, and she has lately whelped, let's go to the place where she was put down, and not far from it you will find all her young ones, I dare warrant you, and kill them all too.

Hunt. Come, gentlemen, come all, let's go to the place where we put down the otter. Look you, hereabout it was that she kennelled; look you, bere it was indeed, for here's her young ones, no less than five; come, let's kill them all.

PIsc. No, I pray, sir, save me one, and I'll try if I can make her tame, as I know an ingenious gentleman in Leicestershire, Mr. Nicholas Seagrave, has done; who hath not only

* The reader need hardly be told, that neither the tail nor any other part of the otter is "fish." The otter will live upon land, and can be trained to hunt and catch fish for its master. Fish is not its only food; and it has been guilty of nocturnal attacks on hen-roosts, rabbit-hutches, \&c. It seldom or never eats the whole of a fish. What is called the "otter's bite," or bonne bouclse, is that part of the fish between the poll or neck and dorsal fin. The tail part of a fish is not succulent enough for the palate of this gourmet. There is no animal of its size that has stronger jaws and teeth than the otter; and in its contests with dogs, it seldom fails to fracture, by biting through one or two of their fore-legs. No dog can bite through the body-skin (so thickly covered is it with impenetrable fur) of the otter. The otter-hound that knows his business, seizes his quarry by the head, and by crushing it comes off victorious.- - ED.

$+i$. e. view. The otter "vents" whien he shows his head above water for the purpose of respiration (venting, "taking in wind") after having been swimming under water to escape his pursucrs.- - KiD. 
made her tame, but to catch fish, and do many other things of much pleasure.

Hunt. Take one with all my heart, but let us kill the rest. And now let's go to an honest ale-house, where we may hav a cup of good barley-wine, and sing "Old Rose," and all of us rejoice together.

VEN. Come, my friend Piscator, let me invite you along with us ; I'll bear your charges this night, and you shall bear mine to-morrow ; for my intention is to accompany you a day or two in fishing.

PIsc. Sir, your request is granted, and I shall be right glad both to exchange such a courtesy, and also to enjoy your company.

VEN. Well, now let's go to your sport of angling.

Pisc. Let's be going with all my heart. God keep you all, gentlemen, and send you meet this day with another bitchotter, and kill her merrily, and all her young ones too.

Ven. Now, Piscator, where will you begin to fish ?

PIsc. We are not yet come to a likely place, I must walk a mile further yet before $I$ begin.

VEN. Well then, I pray, as we walk tell me freely, how do you like your lodging, and mine host, and the company? Is not mine host a witty man?

Pisc. Sir, I will tell you presently what I think of your host : but first, I will tell you, I am glad these otters were killed; but I am sorry there are no more otter-killers; for I know that the want of otter-killers, and the not keeping the fence-months for the preservation of fish, will, in time, prove the destruction of all rivers. And those very few that are left, that make conscience of the laws of the nation, and of keeping days of abstinence, will be forced to eat flesh, or suffer more inconveniences than are yet foreseen.

VEN. Why, sir, what be those that you call the fencemonths?

Pisc. Sir, they be principally three, namely, March, April, and May; for these be the usual months that salmon come out of the sea to spawn in most fresh rivers." And their fry

* Walton is again wrong in his natural history. No salmon spawn in April and May; a very small number of late fish spawn in Marcl. Early salmon spawn in September; but the general spawning season is from the middle of 
would, about a certain time, return back to the salt water, if they were not hindered by weirs and unlawful gins, which the greedy fishermen set, and so destroy them by thousands ; as they would, being so taught by nature, change the fresh for salt water. He that shall view the wise statutes, made in the 13th of Edward I., and the like in Richard II., may see several provisions made against the destruction of fish; and though I profess no knowledge of the law, yet I am sure the regulation of these defects might be easily mended. But I remember that a wise friend of mine did usually say, "that which is everybody's business is nobody's business." If it were otherwise, there could not be so many nets and fish, that are under the statute size, sold daily amongst us; and of which the conservators of the waters should be ashamed.

But, above all, the taking fish in spawning-time may be said to be against nature; it is like the taking the dam on the nest when she hatches her young: a sin so against nature that Almighty God hath in the Levitical law made a law against it (Deut. xii. 6, 7 ).

But the poor fish have enemies enough besides such unnatural fishermen, as namely, the otters that I spake of, the cormorant, the bittern, the osprey, the sea-gull, the heron, the king-fisher, the gorara, the puet, the swan, goose, ducks, and the craber, which some call the water-rat: against all which any honest man might make a just quarrel, but I will not, I will leave them to be quarrelled with, and killed by others ; for I am not of a cruel nature, I love to kill nothing but fish.

And now to your question concerning your host ; to speak truly, he is not to me a good companion; for most of his conceits were either Scripture-jests, or lascivious jests, for

November to the middle of December. The fry, when a year old, go to sea in April and May, and no doubt are destroyed now, as well as in Walton's time, by " unlawful gins" and "greedy fishermen." The fence-months for salmon in Scotland and Ireland are September, October, November, December, January, with exceptions in some of the Irish rivers. The fence-months in England and Wales are regulated by magisterial decrees, rather than by parliamentary edicts. They differ, therefore, in different rivers. In some rivers in Wales, salmon are allowed to be caught until the third week in December. March, April, and May ought to be made fence-months for several of our river-fish, yarticularly for pike and grayling, which spawn in March and April, and are not in condition until the following autumn months. For the liabits, \&c., of the salmon, sce my remarks at the end of chap. vii.-ED. 
which I count no man witty, for the devil will help a man that way inclined, to the first; and his own corrupt nature, which he always carries with him, to the latter ; but a companion that feasts the company with wit and mirth, and leaves out the sin which is usually mixed with them, he is the man; and indeed such a man should have his charges borne, and to such company I hope to bring you this night; for at Trout-hall, not far from this place, where I purpose to lodge to-night, there is usually an angler that proves good company : and let me tell you, good company and good discourse are the very sinews of virtue : but for such discourse as we heard last night, it infects others ; the very boys will learn to talk and swear, as they heard mine host," and another of the company that shall be nameless; - I am sorry the other is a gentleman; for less religion will not save their souls than a beggar's : I think more will be required at the last great day. Well! you know what example is able to do ; and I know what the poet says in the like case,which is worthy to be noted by all parents and people of civility :

\section{many a one}

Owes to his country his religion ;

And in another would as strongly grow,

Had but his nurse or mother taught him so.

This is reason put into verse, and worthy the consideration of a wise man. But of this no more; for though I love civility, yet I hate severe censures. I'll to my own art ; and I doubt not but at yonder tree I shall catch a chub : and then we'll turn to an honest cleanly hostess, that I know right well ; rest ourselves there ; and dress it for our dinner.

VEN. Oh, sir! a chub is the worst fish that swims; I hoped for a trout to my dinner.

PISc. Trust me, sir, there is not a likely place for a trout hereabout : and we staid so long to take leave of your huntsmen this morning, that the sun is got so high, and shines so clear, that I will not undertake the catching of a trout till evening. And though a chub be, by you and many others, reckoned the worst of fish ; yet you shall see I'll make it a good fish by dressing it.

VEN. Why, how will you dress him?

* Of the Thatched House, at Hoddesden, where Piscator passed the first night. 


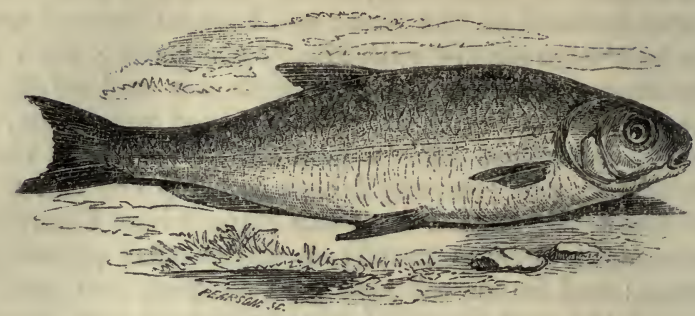

Pisc. I'll tell you by and by, when I have caught him. Look you here, sir, do you see? (but you must stand very close), there lie upon the top of the water, in this very hole, twenty chubs. I'll catch only one, and that shall be the biggest of them all; and that I will do so, I'll hold you twenty to one, and you shall see it done.

VEN. Ay, marry, sir, now you talk like an artist, and I'll say you are one, when I shall see you perform what you say you can do ; but I yet doubt it.

PJsc. You shall not doubt it long, for you shall see me do it presently: loak, the biggest of these chubs has had some bruise upon his tail by a pike, or some other accident, and that looks like a white spot; that very chub I mean to put into your hands presently; sit you but down in the shade, and stay but a little while, and I'll warrant you I'll bring him to you.

Vex. I'll sit down, and hope well, because you seem to be so confident.

PIsc. Look you, sir, there is a trial of my skill,* there he is, that very chub that I showed you with the white spot on his tail : and I'll be as certain to make him a good dish of meat, as I was to catch him. I'll now lead you to an honest ale-house where we shall find a cleanly room, lavender in the windows, and twenty ballads stuck about the wall ; there my hostess, which, I may tell you, is both cleanly and handsome, and civil, hath dressed many a one for me, and shall now dress it after my fashion, and I warrant it good meat.

* Walton does not explain the particulars of his trial of skill. Evidently, the chub was caught by dibbing or daping with a natural insect. See the seventh paragraph of chap. iii,, beginning, "Go to the same hole," etc. See also my remarks at the end of chap. iii.-ED. 
VEx. Come, sir, with all my heart, for I begin to be hungry, and long to be at it, and indeed to rest myself too; for though $I$ have walked but four miles this morning, yet $I$ begin to be weary; yesterday's hunting hangs still upon me.

PIsc. Well, sir, you shall quickly be at rest, for yonder is the house I mean to bring you to.

Come, Hostess, how do you do? Will you first give me a cup of your best drink, and then dress this chub as you dressed my last, when I and my friend were here about eight or ten days ago? But you must do me one courtesy, it must be done instantly.

Hostess. I will do it, Mr. Piscator, and with all the speed I can.

Pisc. Now, sir, has not my hostess made haste? and does not the fish look lovely?

VeN. Both, upon my word, sir, and therefore let's say grace, and fall to eating of it.

PIsc. Well, sir, how do you like it?

Ven. Trust me, 'tis as good meat as I ever tasted: now let me thank you for it, drink to you, and beg a courtesy of you ; but it must not be denied me.

PIsc. What is it, I pray, sir? You are so modest, that methinks I may promise to grant it before it is asked.

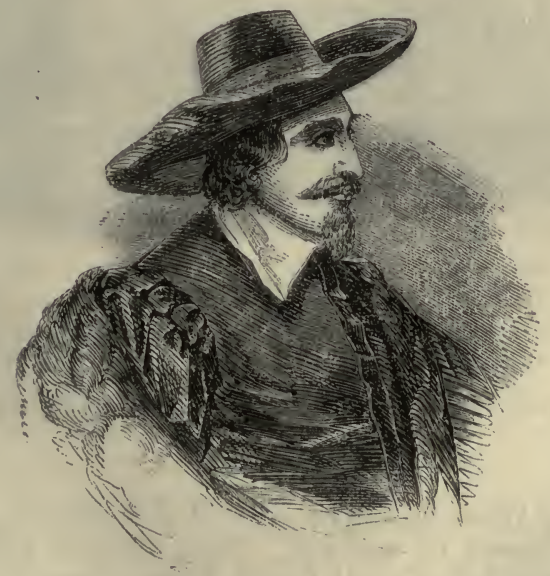


VEN. Why, sir, it is, that from henceforth you would allow me to call you Master, and that really I may be your scholar; for you are such a companion, and have so quickly caught, and so excellently cooked this fish, as makes me ambitious to be your scholar.

Pisc. Give me your hand; from this time forward I will be your master, and teach you as much of this art as I am able; and will, as you desire me, tell you somewhat of the nature of most of the fish that we are to angle for ; and I am sure I both can and will tell you more than any common Angler yet knows.

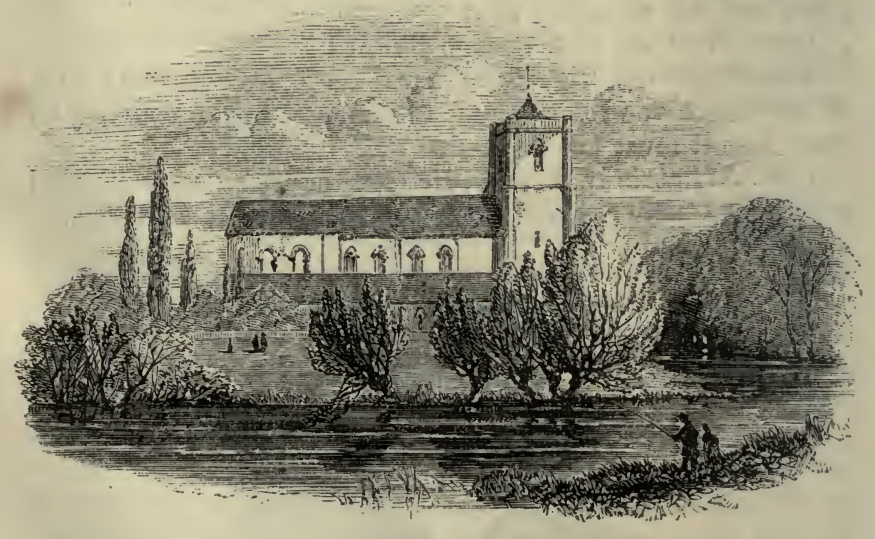

WALTEAII ABBET.

CHAPTER III.

HOW tO FISH FOR, AND TO DRESS, THE CHAVRNDER, OR CHUB.

[Chír 国an.]

Prsc. The Chub, though he eat well thus dressed, yet as he is usually dressed he does not. He is objected against, not only for being full of small forked bones, dispersed through all his body, but that he eats waterish and that the flesh of 
him is not firm, but short and tasteless. The French esteem him so mean as to call him un vilain; nevertheless, he may be so dressed as to make him very good meat; as, namely, if he be a large chub, then dress him thus :-

First, scale him, and then wash him clean, and then take out his guts; and to that end make the hole as little and near to his gills, as you may conveniently, and especially make clean his throat from the grass and weeds that are usually in it ; for if that be not very clean, it will make him to taste very sour. Having so clone, put some sweet herbs into his belly; and then tie him with two or three splinters to a spit, and roast him, basted often with vinegar, or rather verjuice and butter, with good store of salt mixed with it. Being thus dressed, you will find him a much better dish of meat than you, or most folk, even than anglers themselves, do imagine: for this dries up the fluid watery humour with which all chubs do abound.

But take this rule with you, that a chub newly taken and newly dressed is so much better than a chub of a day's keeping after he is dead, that I can compare him to nothing so fitly as to cherries newly gathered from a tree, and others that have been bruised and lain a day or two in water. But the chub being thus used, and dressed presently, and not washed after he is gutted (for note, that lying long in water, and washing the blood out of any fish after they be gutted, abates much of their sweetuess), you will find the chub (being dressed in the blood, and quickly) to be such meat as will recompense your labour, and disabuse your opinion.

Or you may dress the chavender or chub thus :-

When you have scaled him, and cut off his tail and fins, and washed him very clean, then chine or slit him through the middle, as a salt fish is usually cut; then give him three or four cuts or scotches on the back with your knife, and broil him on charcoal, or wood-coal that is free from smoke, and all the time he is a-broiling baste him with the best sweet butter, and goorl store of salt mixed with it ; and to this add a little thyme cut exceeding small, or bruised into the butter. The cheven thus dressed hath the watery taste taken away, for which so many except against him. Thus was the cheven dressed that you now liked so well, and commended so much. But note again, that if this chub that you ate of, had been kept till to-morrow, he had not been worth a rush. And remember that his throat be washed very clean, 
I say very clean, and his body not washed after he is gutted, as indeed no fish should be.

Well, scholar, you see what pains I have taken to recover the lost credit of the poor despised chub.* And now I will give you some rules how to catch him; and I am glad to enter you into the art of fishing by catching a chub, for there is no fish better to enter a young angler, he is so easily caught, but then it must be this particular way.

Go to the same hole in which I caught my chub, where in most hot days you will find a dozen or twenty chevens floating near the top of the water : get two or three grasshoppers as you go over the meadow, and get secretly behind the tree, and stand as free from motion as is possible ; then put a grasshopper on your hook, and let your hook hang a quarter of a yard short of the water, to which end you must rest your rod on some bough of the tree. But it is likely the chubs will sink down towards the bottom of the water, at the first shadow of your rod (for chub is the fearfulest of fishes), and will do so if but a bird flies over him and makes the least shadow on the water. But they will presently rise up to the top again, and there lie soaring till some shadow affrights them again. I say, when they lie upon the top of the water, look out the best chub (which you, setting yourself in a fit place, may very easily see), and move your rod as softly as a

* The edible properties of the chub are very lightly prized. That celebrated cuisinier, Alexis Soyer, says, in his "Modern Housewife," p. 160- "Chub I do not think much of, but it no doubt depends on the river where taken; those caught in the winter are best. They may be cooked like carp." M. Soyer gives an excellent recipe for cooking the latter fish. "Baked Carp.-Procure a good-sized carp, stuff it like the pike (with veal stuffing, adding a few fillets of anchovies and chopped lemon-peel), then put it into a baking-dish, with two onions, one carrot, one turnip, one head of celery, and a good bouquet of parsley, thyme, and bay-leaf; moisten with two glasses of port wine, half a pint of water, salt, pepper, and oil, and put it in a moderate oven about two hours to bake; try if done with a knife, which is the case if the flesh leave the bone easily; dress upon a dish without a napkin; then have ready the following sauce: mince a large Spanish onion with two common ones, and put them into a stew-pan with three spoonfuls of salad oil, sauté rather a yellow colour, add two glasses of port wine and one spoonful of flour, mix all well together, add a pint of broth (reserved from some soup), or water, with half an ounce of glaze, or half a gill of brown gravy; boil it up, drain the stock the carp was cooked in from the vegetables, which also add to the sauce: boil well at the corner of the stove, skim, and when rather thick, add a teaspoonful of Harvey sauce, one of essence of anchovies, and a little Cayenne pepper, pour all the liquor drained from the fish out of your dish, sauce over, and serve." The above is a capital way of cooking coarse river-fish, chub, bream, tench, and barbel, and even very large roach.-ED. 
snail moves, to that chub you intend to catch; let your bait fall gently upon the water three or four inches before him, and he will infallibly take the bait. And you will be as sure to catch him ; for he is one of the leather-mouthed fishes,* of which a hook does scarce ever lose its hold; and therefore give him play enough before you offer to take him out of the water. Go your way presently; take my rod and do as I bid you ; and I will sit down and mend my tackling till you return back.

VEN. Truly, my loving master, you have offered me as fair as I could wish. I'll go, and observe your directions.

Look you, master, what I have done, that which joys my heart, - caught just such another chub as yours was.

Prsc. Marry, and I am glad of it: I am like to have a towardly scholar of you. I now see that with advice and practice, you will make an angler in a short time. Have but a love to it ; and I'll warrant you.

VEN. But, master, what if I could not have found a grasshopper?

PISc. Then I may tell you, that a black snail, with his belly slit to show his white, or a piece of soft cheese, $\uparrow$ will usually do as well. Nay, sometimes a worm, or any kind of fly, as the ant-fly, the flesh-fly, or wall-fly; or the dor or beetle, which you may find under cow-dung, or a bob, which you will find in the same place, and in time will be a beetle; it is a short white worm, like to and bigger than a gentle, or a cod-worm, or a case-worm, any of these will do very well to fish in such a manner. And after this manner you may catch a trout in a hot evening: when as you walk by a brook, and shall see or hear him leap at flies, then if you get a grasshopper, put it on your hook, with your line about two yards long, standing behind a bush or tree where his hole is, and make your bait stir up and down on the top of the water, you may, if you stand close, be sure of a bite, but not sure to catch him, for he is not a leather-mouthed fish : and after

* Leather-mouthed fish are those possessing tough palates; they are generally of the carp tribe. The barbel is a good example. Tender-mouthed fish are mostly of the salmon tribe, with crisp and tender palates. The latter fish when hooked, must be played with a delicate hand, lest the hook-hold tear away; the former may be played roughly without any such danger.-ED.

+ In fishing with cheese, snails, or worms, you must not angle at the top or surface of the water, but at the bottom, with leaded line and middle-sized float. -ED. 
this manner you may fish for him with almost any kind of live fly, but especially with a grasshopper.

VEN. But before you go further, I pray, good master, what mean you by a leather-mouthed fish?

PIsc. By a leather-mouthed fish I mean such as have their teeth in their throat, as the chub or cheven, and so the barbel, the gudgeon, and carp, and divers others have; and the hook being stuck into the leather or skin, or the mouth of such fish, does very seldom or never lose its hold: but, on the contrary, a pike, a perch, or trout, and so some other fish, which have not their teeth in their throats, but in their mouths, which you shall observe to be very full of bones, and the skin very thin, and little of it; I say, of these fish the hook never takes so sure hold, but you often lose your fish, unless he have gorged it.

VEN. I thank you, good master, for this observation; but now, what shall be done with my chub or cheven that I have caught?

Prsc. Marry, sir, it shall be given away to some poor body, for I'll warrant you I'll give you a trout for your supper: and it is a good beginning of your art to offer your first-fruits to the poor, who will both thank you and God for it, which I see by your silence you seem to consent to. And for your willingness to part with it so charitably, I will also teach more concerning chub-fishing: you are to note that in March and April he is usually taken with worms; in May, June, and July, he will bite at any fly, or at cherries, or at beetles with their legs and wings cut off, or at any kind of snail, or at the black bee that breeds in clay walls. And he never refuses a grasshopper, on the top of a swift stream, * nor, at the bottom, the young humble-bee that breeds in long grass, and is ordinarily found by the mower of it. In August, and in the cooler months, a yellow paste made of the strongest cheese, and pounded in a mortar, with a little butter and saffron, so much of it, as being beaten small, will turn it to a lemon colour. And some make a paste, for the winter months, at which time the chub is accounted best (for then it is observed that the forked bones are lost, or turned into a kind of gristle,

* In the Thames, above Richmond, the best way of using the grasshopper for chub, is to fish with it as with an artificial fly; the first joints of the legs must be pinched off; and in this way, when the weed is rotten, which is seldom till September, the largest dace are taken.-H. 
especially if he be baked), of cheese and turpentine. He will bite also at a minnow, or penk, as a trout will : of which I shall tell you more hereafter, and of divers other baits. But take this for a rule, that, in hot weather, he is to be fished for to wards the mid-water, or near the top; and in colder weather nearer the bottom. And if you fish for him on the top, with a beetle, or any fly, then be sure to let your line be very long and to keep out of sight. And having told you that his spawn is excellent meat, and that the head of a large cheven, the throat being well washed, is the best part of him, I will say no more of this fish at the present, but wish you may catch the next you fish for.*

But, lest you may judge me too nice in urging to have the chub dressed so presently after he is taken, I will commend to your consideration how curious former times have been in the like kind.

You shall read in Seneca, his "Natural Questions," Lib. 3, Cap. 17, that the ancients were so curious in the newness of their fish, that that seemed not new enough that was not put alive into the guest's hand; and he says that to that end they did usually keep them living in glass bottles in their dining-rooms : and they did glory much in their entertaining of friends, to have that fish taken from under their table alive that was instantly to be fed upon. And he says, they took great pleasure to see their Mullets change to several colours, when they were dying. But enough of this, for I doubt I have stayed too long from giving you some observations of the trout, and how to fish for him, which shall take up the next of my spare time.

[Note ox Chub-Fishing.-The scientific name of this well-known fish is Cyprinus cephalus, which means, the big-headed carp. Although Blaine, in his celebrated "Encyclopædia of Rural Sports," describes its colour thus, - " silvery bluish carp, with olivaceous back,"-I should rather call it the golden olive carp. The scales on its sides have certainly more of a yellow or golden hue, than of a bright or silvery one. The following description from the author just cited, is on the whole good:- " It much resembles the carp, but is of a longer form; the body

* Piscator gives in this paragraph some very good advice touching angling for chub. Walton understood the matter well, and was no doubt a great adept in the art of fishing for chub and barbel. However, chub very rarely indeed take the minnow, or any other sort of fish-bait. Lob-worms, gentles, prepared cheese, honey-paste, insects, natural and artificial, are the best baits for them. Study my directions at the end of this chapter.-ED. 
is oblong, rather round, and of a pretty equal thickness in the greater part of the slope; the scales are large, the irides silvery; the cheeks of the same colour; the head and back of a deep duslry green; the sides silvery, but in the summer yellow; the belly white; the pectoral fins of a pale yellow; the ventral and anal fins red; the tail forked, of a brownish hue, but tinged with blue at the end; and the chub is altogether a handsome fish." So it is, a very handsome fish when in full season and fresh eaught. Authors differ as to the period of the year at which this fish is in best condition. It spawns in April, and Blaine says it soon recovers its condition. Daniel says it is not in prime condition until December. I am inclined to agree with the latter authority. I have found chub in tolerable condition in the Thames in July, but in the very same month I have caught the fish miserably emaciated in the Trent. There is no general rule for the colour or condition of fresh-water fish. Each depends on the river in which fish are bred, and on the atmospheric influence of particular seasons. Chub generally prefer still waters, weedy, and over-hung with bushes. In truth, the fish is a pond one, and in ponds fed with a slight dash of running water, provided they are weedy, and so give a harbour for the breed of insects, they thrive well. To bring them to a large size, they should be fed with worms, larvæ, grubs, horse-gentles, grains, pieces of soft cheese, prepared greaves, and even raw beef cut into threads the size of dew-worms. I have frequently caught chub in streams; for instance, in the Trent at Sawley bridge, and in the Thames at Sunbury. Daniel says-"The haunts of the Chub are in rivers whose bottoms are of sand or clay, or which are bounded by clayey banks; particularly in deep holes, shaded by trees, weeds, etc." The late Mr. Blaine writes, "They are sometimes to be met with in rocky rivers, but such are always found to have some deeps with soft bottoms of their own, or are found to communicate with waters which have. In fact, chub thrive only in such rivers as present a diversity of rocky and strong gravelly currents, widening occasionally into large and deep pools, where sand and ooze accumulate. It is here they flourish; and such situations they choose as their winter hiding-places. In chub rivers, such pools are never without them at any season, which has given rise to the angler's adage, 'Once a chub-hole always a chub-hole.' In summer, river chub shelter themselves from the heat, more particularly in such deeps and pools as are overhung with foliage or trees. In stagnant or open waters they hide themselves under aquatic plants." The reader knows, I hope, now the most likely spots wherein to find chub. I must now tell him the best modern ways to angle for this fish. At the bottom it takes gentles, well-scoured large worms, prepared cheese, and bullock's pith or brains. The two latter baits are generally used in winter. At the middle and surface of the water, the chub takes grasshoppers, cockchafers, and flies, artificial and natural. In my opinion chub are best caught by fishing for them at the top of the water, either with artificial or living flies. To be successful with the former in deep water, it should be ruffled by the wind of a gloomy day; but in the swift streams of rivers, wind is not necessary. The best flies are large red, brown, and (in bright days) 
black palmers. Winging them is sometimes an improvement. In using natural flies, moths, small butterflies, brown beetles, cockchafers, the May-fly, or housefly, it is necessary to have recourse to that branch of the angling art, called dibbing, dipping, or daping, which is practised thus:- If you (I write as if I were speaking to my reader) are about to angle in a river, the banks of which are wooded, a shortish (ten feet or so) rod must be used. A winch, a winch-line, and a gut casting line, will be required. Having baited the hook, viz., pat on it the live insect as delicately as may be, by inserting delicately the point of the hook in its back, you must twirl all that part of the line beyond the rod around it just as coachmen do their whips before hanging them up. This done, pass the point of the rod through any bushes, or beneath any trees, that may grow on the river's bank, and then tuntwirling the line, the bait, with proper management, will fall gently and naturally on the surface of the water, and be taken not only by any chnb, but by any trout, roach, or dace, that may happen to see it. When trees do not intervene, this method of dibbing is not necessary; but where they do, it is absolutely necessary, and is a most killing, or rather captivating practice. No obstructions being in the way, the line on the winch must be of stout floss silk, and will form then what is technically called the "blow-line." To this, add about a yard and a half of fine gut, to the end of which attach the hook link. Now put on your insect, and standing with the wind to your back, let out as much of the "blow-line" as is required, and letting go the insect-bait, which you must hold delicately between the fore finger and thumb of the left hand, it will be carried the requisite distance on to the water. The principles of dibbing are involved in the two processes I have briefly explained. In bush dibbing I said a short rod was required; in dibbing with the floss-silk line a rod of twelve feet in length must be used. Wherever there are wide leaves on the surface of the water, it would be well to direct the bait on to each one of them in suecession, and then to roll it off on to the water. As chub, at midday, in warm weather, lie concealed under such leaves, they will in nine cases out of ten take any insect that drops off them. Walton mentions, and with good reason, the extreme shyness of this fish. If it see the angler, it will never take his bait, be it ever so tempting. He must, therefore, keep as far away from the river as possible, and never fish with the sun to his back. It is a general rule in angling, that the angler whilst at his recreation, must look the sun in the face. There will then be no shadow of rod or fisherman in the water.-ED.]

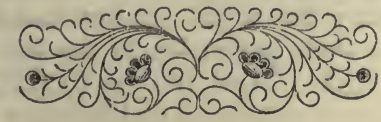




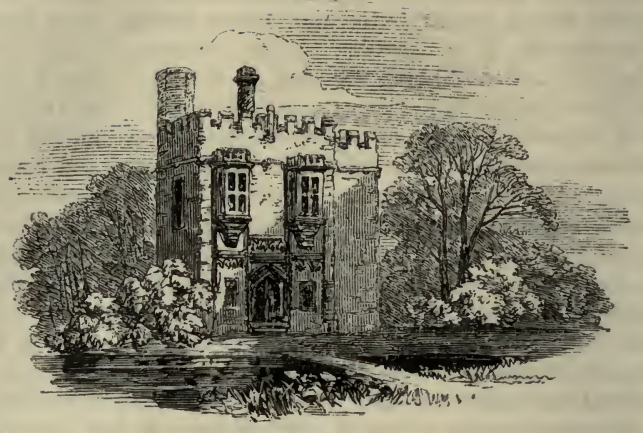

OLD RIE HOTSS

\section{CHAPTER IV.}

OBSERVATIONS OF THE NATURE AND BREEDING OF THE TROUT, AND HOW TO FISH FOR HIM; AND THE MILKMAID'S SONG.

[Cfir子 田an.]

The Trout is a fish highly valued both in this and foreign nations : he may be justly said, as the old poet said of wine, and we English say of venison, to be a generous fish : a fish that is so like the buck that he also has his seasons; for it is observed, that he comes in and goes out of season with the stag and buck; Gesner says, his name is of a German offspring, and says he is a fish that feeds clean and purely, in the swiftest streams, and on the hardest gravel ; and that he may justly contend with all fresh-water fish, as the Mullet may with all sea-fish, for precedency and daintiness of taste, and that being in right season, the most dainty palates have allowed precedency to him.

And before I go further in my discourse, let me tell you, that you are to observe, that as there bo some barren does, that are good in summer, so there be some barren trouts that are good in winter; but there are not many that are so, for usually they be in their perfection in the month of May, and decline with the buck. Now you are to take notice, that in several countries, as in Germany and in other parts, compared to ours. fish differ much in their bigness and shape, and other ways, and so do trouts; it is well known that in the Lake 
Leman, the Lake of Geneva, there are trouts taken of three cubits long, as is affirmed by Gesner, a writer of good credit; and Mercator* says, the trouts that are taken in the Lake of Geneva, are a great part of the merchandize of that famous city. And you are further to know, that there be certain waters, that breed trouts remarkable both for their number and smallness. I know a little brook in Kent, that breeds them to a number incredible, and you may take them twenty or forty in an hour, but none greater than about the size of a gudgeon : there are also in divers rivers, especially that relate to, or be near to the sea, as Winchester, or the Thames about Windsor, a little trout called samlet, or skegger trout (in both which places I have caught twenty or forty at a standing), that will bite as fast and as freely as minnows: these be by some taken to be young salmon; but in those waters they never grow to be bigger than a herring. $t$

There is also in Kent, near to Canterbury, a trout called there a Fordidge trout, a trout that bears the name of the town where it is usually caught, that is accounted the rarest of fish; many of them near the bigness of a salmon, but known by their different colour; and in their best season they cut very white; and none of these have been known to be caught with an angle, unless it were one that was caught by Sir George Hastings, an excellent augler, and now with God; and he hath told me, he thought that trout bit not for hunger

* Gerard Mercator, of Ruremond in Flanders, a man of so intense application to mathematical studies, that he neglected the necessary refreshments of uature. He engraved with his own hand, and coloured the maps to his geographical writings. He wrote several books of theology; and died 1594.- H.

+ 'The skegger here alluded to is no doubt the young salmon in its first year before it has paid its first visit to the sea. As salmon has disappeared from the Thames, so have skeggers, or salmon fry. The Lake of Geneva still produces very large trout, which are frequently cooked on the spot, and sent express to Paris. Still, I do not think that any of them now grow to the length of " three cubits." They are not unfrequently caught weighing twentyfour or thirty pounds. Trout every bit as large are caught in some of the loughs and lochs of Ireland and Scotland. The smallest species of trout is now called. "the parr," and very likely that is the fish to which Walton alludes in this passage,- "I know a little brook in fient, that breerls them to a number incredible, and you may take them twenty or forty in the hour, but none greater than about the size of a gudgeon." When Walton mentions "barren trouts. that are good in winter," he falls into a common error. The barren trout are really male trout, which have shed their milt over the ova of the female fish in the early spawning months, August and September. The male fish very rapirly recovers from the exhausting process of procreation. Not so the female, which. if a large fish, is not fully convalescent until the May next following her accouchement.-ED. 
but wantonness; and it is rather to be believed, because both he, then, and many others before him, have been curious to search into their bellies, what the food was by which they lived; and have found out nothing by which they might satisfy their curiosity.

Concerning which you are to take notice, that it is reported by good authors, that grasshoppers, and some fish, have no mouths, but are nourished and take breath by the porousness of their gills, man knows not how : and this may be believed, if we consider that when the raven hath hatched her eggs, she takes no further care, but leaves her young ones to the care of the God of nature, who is said, in the Psalms, "to feed the young ravens that call upon him." And they be kept alive, and fed by dew, or worms that breed in their nests, or some other ways that we mortals know not; and this may be believed of the Fordidge trout, which, as it is said of the Stork (Jerem. viii. T), that, "he knows his season," so he knows his times, I think almost his day of coming into that river out of the sea, where he lives, and, it is like, feeds nine months of the year, and fasts three in the river of Fordidge. And you are to note that those townsmen are very punctual in observing the time of beginning to fish for them; and boast much that their river affords a trout, that exceeds all others. And just so does Sussex boast of several fish; as namely, a Shelsey cockle, a Chichester lobster, an Arundel mullet, and an Amerly trout.

And now for some confirmation of the Fordidge trout: you are to know that this trout is thought to eat nothing in the fresh water, ${ }^{*}$ and it may be better believed, because it is well known that swallows, and bats, and wagtails, which are called half-year birds, and not seen to fly in England for six months in the year, but about Michaelmas leave us for a better climate than this; yet some of them that have been left behind their fellows, have been found many thousands at a time, in hollow trees, or clay caves; where they have been

* There is no species of trout whatsoever that does not feed in fresh water. The sea-trout (salmo trutta) and the bull-trout (salmo ferox), though they migrate to sea, like the salmon, and for a time thrive and fatten therein, return to their native rivers, and feed on small fish and insects; indeed, they are the greatest destroyers of salmon-fry. There is no fish that has its mouth sewn up as it were; and what Walton says about grasshoppers and frogs having no mouths is simply laughable. All that Walton says of the Fordidge, a river near Canterbury, and of ravens, etc., is perfectly fabulous.-ED. 
observed to live and sleep out the whole winter without meat; and so Albertus observes, that there is one kind of frog that hath her mouth naturally shut up about the end of August, and that she lives so all the winter : and though it be strange to some, yet it is known to too many among us to be doubted.

And so much for these Fordidge trouts, which never afford an angler sport, but either live their time of being in the fresh water, by their meat formerly got in the sea (not unlike the swallow or frog), or by the virtue of the fresh water only; or, as the birds of Paradise and the chamelion are said to live, by the sun and the air.

There is also in Northumberland a trout called a bull-trout, of a much greater length and bigness than any in the southern parts. And there are, in many rivers that relate to the sea, salmon-trouts, as much different from others, both in shape and in their spots, as we see sheep in some countries differ one from another in their shape and bigness, and in the fineness of their wool. And, certainly, as some pastures breed larger sheep, so do some rivers, by reason of the ground over which they run, breed larger trouts.

Now the next thing that I will commend to your consideration is, that the trout is of a more sudden growth than other fish. Concerning which, you are also to take notice, that he lives not so long as the perch, and divers other fishes do, as Sir Francis Bacon hath observed in his "History of Life and Death."

And now you are to take notice, that he is not like the crocodile, which if he lives never so long, yet always thrives till his death. And you are to know, that he will about, especially before, the time of his spawning, get almost miraculously through weirs and flood-gates against the streams; even through such high and swift places as is almost incredible. Next, that the trout usually spawns about October or November, but in some rivers a little sooner or later: which is the more observable, because most other fish spawn in the spring or summer, when the sun hath warmed both the earth and the water, and made it fit for generation. And you are to note that he continues many months out of season; for it may be observed of the trout, that he is like the buck or the ox, that he will not be fat in many months, though he go in the very same pasture that horses do, which will be fat in one month: and so you may observe that most 
other fishes recover strength, and grow sooner fat and in season than the trout doth.

And next you are to note, that till the sun gets to such a height as to warm the earth and the water, the trout is sick, and lean, and lousy, and unwholesome: for you shall in winter find him to have a big head, and then to be lank, and thin, and lean: at which time many of them have sticking on them: sugs, or trout-lice, which is a kind of worm, in shape like a clove or pin, with a big head, and sticks close to him and sucks his moisture ; those, I think, the trout breeds himself, and never thrives till he free himself from them, which is when warm weather comes; and then, as he grows stronger, he gets from the dead, still water, into the sharp streams, and the gravel, and there rubs off these worms or lice; and then, as he grows stronger, so he gets him into swifter and swifter streams, and there lies at the watch for any fly or minnow that comes near to him; and he especially loves the May-fly, which is bred of the cod-worm or cadis; and these make the trout bold and lusty, and he is usually fatter and better meat at that end of that month [May] than at any time of the year.

Now you are to know that it is observed, that usually the best trouts are either red or yellow; though some (as the Fordidge trout) be white and yet good; but that is not usual: and it is a note observable, that the female trout hath usually a less head, and a deeper body than the male trout, and is usually the better meat. And note, that a hog-back and a little head to either trout, salmon, or any other fish, is a sign that that fish is in season.

But yet you are to note, that as you see some willows or palm-trees bud and blossom sooner than others do, so some trouts be, in rivers, sooner in season : and as some hollies or oaks are longer before they cast their leaves, so are some trouts in rivers longer before they go out of season.

And you are to note, that there are several kinds of trouts: but these several kinds are not considered but by very few men; for they go under the general name of trouts : just as pigeons do, in most places; though, it is certain, there are tame and wild pigeons; and of the tame, there be helmets and runts, and carriers and cropers, and indeed too many to name. Nay, the Royal Society have found and published lately, that there be thirty and three kinds of spiders; and yet all, for aught I. know, go under that one general name of spider. And it is so with many kinds of fish, and of trouts 
especially; which differ in their bigness and shape and spots and colour. The great Kentish hens may be an instance, compared to other hens. And, doubtless, there is a kind of small trout, which will never thrive to be big; that breeds very many more than others do, that be of a larger size: which you may rather believe, if you consider that the little wren and titmouse will have twenty young ones at a time,* when usually the noble hawk, or the musical thrassel or blackbird, exceed not four or five.

And now you shall see me try my skill to catch a trout ; and at my next walking, either this evening or to-morrow morning, I will give you direction how you yourself shall fish for him.

VEN. Trust me, master, I see now it is a harder matter to catch a trout than a chub : for I have put on patience, and followed you these two hours, and not seen a fish stir, neither at your minnow nor your worm.

PIsc. Well, scholar, you must endure worse luck sometime, or you will never make a good angler. But what say you now? There is a trout now, and a good one too, if I can but hold him, and two or three more turns will tire him. Now you see he lies still, and the sleight is, to land him; reach me that landing net; so, sir, now he is mine own, what say you now? Is not this worth all my labour and your patience?

VEN. On my word, master, this is a gallant trout; what shall we do with him?

PIsc. Marry, e'en eat him to supper; we'll go to my hostess, from whence we came ; she told me, as I was going out of door, that my brother Peter, a good angler and a cheerful companion, had sent word that he would lodge there tonight, and bring a friend with him. My hostess has two beds, and I know you and I may have the best; we'll rejoice with my brother Peter and his friend, tell tales, or sing ballads, or make a catch, or find some harmless sport to content us and pass away a little time; without offence to God or man.)

VEN. A match, good master, let's go to that house; for the linen looks white, and smells of lavender, and I love to lie in a pair of sheets that smell so. Let's be going, good master, for I am hungry again with fishing.

Prsc. Nay, stay a little, good scholar; I caught my last

* If Walton had said half the number, he would have been right. The wren will sometimes lay a dozen eggs, but cannot hatch the whole of them,-ED. 
trout with a worm ; now I will put on a minnow, and try a quarter of an hour about yonder trees for another; and so walk towards our lodging. Look you, scholar, thereabout we shall have a bite presently or not at all. Have with you, sir! o' my word I have hold of him. Oh ! it is a great loggerheaded chub; come hang him upon that willow twig, and let's be going. But turn out of the way a little, good scholar! towards yonder high honey-suckle hedge; there we'll sit and sing, whilst this shower falls so gently upon the teeming earth, and gives yet a sweeter smell to the lovely flowers that adorn these verdant meadows.

Look! under that broad beech tree I sat down, when I was last this way a-fishing. And the birds in the adjoining greve seemed to have a friendly contention with an echo, whose dead voice seemed to live in a hollow tree, near to the brow of that primrose hill. There I sat viewing the silver streams glide silently towards their centre, the tempestuous sea; yet sometimes opposed by rugged roots and pebble-stones, which broke their waves and turned them into foam. And sometimes I beguiled time by viewing the harmless lambs; some leaping securely in the cool shade, whilst others sported themselves in the cheerful sun; and saw others craving comfort from the swollen udders of their bleating dams. As I thus sat, these and other sights had so fully possessed my soul with content, that I thought, as the poet hath happily expressed it,

"I was for that time lifted abore earth, And possess'd joys not promised in my birth."

As I left this place, and entered into the next field, a second pleasure entertained me: 'twas a handsome milkmaid, that had not yet attained so much age and wisdom as to load her mind with any fears of many things that will never be, as too inany men too often do: but she cast away all care, and sung like a nightingale: her voice was good, and the ditty fitted for it: it was that smooth song which was made by Kit Marlow, now at least fifty years ago: and the milkmaid's mother sung an answer to it, which was made by Sir Walter Raleigh in his younger days.

They were old-fashioned poetry, but choicely good, I think much better than the strong lines that are now in fashion in this critical age. Look yonder! on my word, yonder they both be a-milking again. I will give her the chub, and persuade them to sing those two songs to us. 
God speed you, good woman! I have been a-fishing, and am going to Bleak Hall to my bed, and having caught more fish than will sup myself and my friend, I will bestow this upon you and your daughter, for I use to sell none.

MrLx-W. Marry, God requite you, sir, and we'll eat it cheerfully; and if you come this way a-fishing two months ence, a grace of God, I'll give you a syllabub of new verjuicein a new-made haycock for it, and my Maudlin shall sing you one of her best ballads; for she and I both love all anglers, they be such honest, civil, quiet men; in the mean time will you drink a draught of red cow's milk ? you shall have it freely

Pisc. No, I thank you; but, I pray, do us a courtesy that shall stand you and your daughter in nothing, and yet we will think ourselves still something in your debt; it is but to sing us a song that was sung by your daughter when I last passed over this meadow about eight or nine days since.

Milk-W. What song was it, I pray? Was it "Come Shepherds, deck your heads ?" or, "As at noon Dulcina rested ?" or, "Philida flouts me?" or, "Chevy Chace?" or, "Johnny Armstrong?" or, "Troy Town ?"

Pisc. No, it is none of those; it is a song that your daughter sung the first part, and you sung the answer to it.

Mrnk-W. O, I know it now. I learned the first part in my golden age, when I was about the age of my poor daughter; and the latter part, which indeed fits me best now, but two or three years ago, when the cares of the world began to take hold of me: but you shall, God willing, hear them both, and sung as well as we can, for we both love anglers. Come, Maudlin, sing the first part to the gentleman with a merry heart, and I'll sing the second, when you have done.

\section{The Jtilkmaio's Song.}

Come live with me, and be my love, And we will all the pleasures prove That valleys, groves, or hills, or field, Or woods and steepy mountains yield;

Where we will sit upon the rocks, And see the shepherds feed our flocks By shallow rivers, to whose falls Melodious birds sing madrigals.

And I will make thee beds of roses, And then a thousand fragrant posies, A cap of flowers, and a kirtle

Embroider'd all with leaves of myrtle ; 
A gown made of the finest wool

Which from our pretty lambs we pull ;

Slippers lined choicely for the cold,

With buckles of the purest gold ;

A belt of straw and ivy buds,

With coral clasps and amber studs :

And if these pleasures mar thee move,

Come live with me, and be my love.

Thy silver dishes for my meat,

As precious as the gods do eat,

Shall, on an ivory table, be

Prepared each day for thee and me.

The shepherd swains shall dance and sing,

For thy delight, each May morning.

If these delights thy mind may move,

Then live with me, and be my love.*

VEN. Trust me, master, it is a choice song, and sweetly sung by honest Maudlin. I now see it was not without cause, that our good Queen Elizabeth did so often wish herself a milkmaid all the month of May, because they are not troubled with fears and cares, and sing sweetly all the day, and sleep securely all the night : and without doubt, honest, innocent, pretty Maudlin does so. I'll bestow Sir Thomas Overbury's milkmaid's wish upon her, "That she may die in the spring, and being dead, may have good store of flowers stuck round about her winding sheet." +

\section{Th: fetilkmaið's fatotyer's Answer.}

If all the world and love were young,

And truth in every shepherd's tongue,

These pretty pleasures might me move

To live with thee, and be thy love.

But Time drives flocks from field to fold,

When rivers rage and rocks grow cold;

Then Philomel becometh dumb,

And age complains of care to come.

* Dr. Warburton, in his Notes on "The Merry Wives of Windsor," ascribes this song to Shakspere. It is true, Sir Hugh Evans, in the third act of that play, sings four lines of it; and it occurs in a collection of poems said to be Shakspere's, printed by 'Tho. Cotes for John Benson, 12mo, 1640, with some variations. On the contrary, it is to be found, with the name of Christopher Marlow to it, in "England's Helicon ;" and Walton has just said it was made by Kit Marlow : the reader will judge of these evidences as he pleases.

As to the song itself, though a beautiful one, it is not so purely pastoral as it s generally thouglit to be; buckles of gold, coral clasps, and amber studssilver dishes and ivory tables - are luxuries, and consist not with the parsimony and simplicity of rural life and manners.

\& Sir Thomas Overbury's "Character of a fair and happy Milk-maid," grinied with his poem entitled "The Wife," in $12 \mathrm{mo}, 16 \mathrm{C5}$. 
The fiowers do fade, and wanton fields

To wayward winter reckoning yields.

A honey tongue, a heart of gall,

Is fancy's spring, but sorrow's fall.

Thy gowns, thy shoes, thy beds of roses,

Thy cap, thy kirtle, and thy posies,

Soon break, soon wither, soon forgotten ;

In folly ripe, in reason rotten.

Thy belt of straw and ivy buds,

Thy coral clasps and amber studs,

All these in me no means can move

To come to thee and be thy love.

What should we talk of dainties, then,

Of better meat than's fit for men?

These are but vain; that's only good

Which God hath bless'd, and sent for food.

But could youth last and love still breed-

Had joys no date, or age no need-

Then those delights my mind might move

To live with thee, and be thy love.

Mother. Well ! I have done my song. But stay, honest anglers; for I will make Maudlin to sing you one short song more. Maudlin! sing that song that you sung last night, when young Coridon the shepherd played so purely on his oaten pipe to you and your cousin Betty.

MAUd. I will, mother.

I married a wife of late,

The more's my unhappy fate ;

I married her for love,

As my fancy did me move,

And not for a worldly estate ;

But, Oh ! the green sickness

Soon changed her likeness,

And all her beauty did fail.

But 'tis not so

With those that go

Through frost and snow,

As all men know,

And carry the milking-pail.

Prsc. Well sung, good woman; I thank you. I'll give you another dish of fish one of these days, and then beg another song of you. Come, scholar, let Maudlin alone; do not you offer to spoil her voice. Look, yonder comes mine hostess, to call us to supper. How now? Is my brother Peter come?

Host. Yes, and a friend with him; they are both glad to hear that you are in these parts, and long to see you, and long to be at supper, for they be very hungry. 


\section{CHAPTER V.}

MORE DIRECTIONS HOW TO FISH FOR, AND HOW TO MAKE FOR THE TROUT AN ARTIFICIAL MINNOW AND FLIES; WITH SOME MERRIMENT.

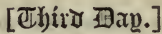

PIsc. Well met, brother Peter: I heard you and a friend would lodge here, to-night, and that hath made me to bring my friend to lodge here too. My friend is one that would fain be a brother of the angle; he hath been an angler but this day, and I have taught him how to catch a chub by daping with a grasshopper, and the chub that he caught was a lusty one of nineteen inches long. But pray, brother Peter, who is your companion?

Peter. Brother Piscator, my friend is an honest countryman, and his name is Coridon, and he is a downright witty companion, that met me here purposely to be pleasant and eat a trout, and I have not yet wetted my line since we met togethèr; but I hope to fit him with a trout for his breakfast, for I'll be early up.

Prsc. Nay, brother, you shall not stay so long: for, look you, here is a trout will fill six reasonable bellies.

Come, hostess, dress it presently, and get us what other meat the house will afford, and give us some of your best barley-wine, the good liquor that our honest forefathers did use to drink of ; the drink which preserved their health, and made them live so long, and do so many good deeds.

Peter. O' my word, this trout is perfect in season. Come I thank you, and here is a hearty draught to you, and to all the brothers of the angle wheresoever they be, and to my young brother's good fortune to-morrow. I will furnish him with a rod if you will furnish him with the rest of the tackling; we will set him up and make him a fisher. And I will tell him one thing for his encouragement, that his fortune hath made him happy to be scholar to such a master; a master that knows as much, both of the nature and breeding of fish, as any man ; and can also tell him as well how to catch and cook them, from the minnow to the salmon, as any that I ever met withal. 


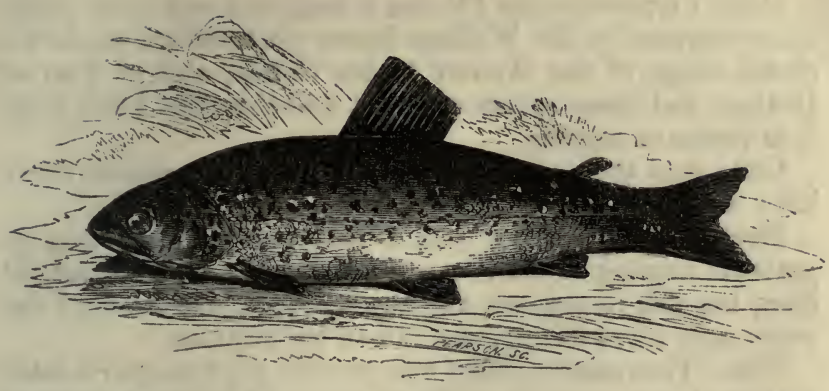

Pisc. Trust me, brother Peter, I find my scholar to be so suitable to my own humour, which is, to be free and pleasant and civilly merry, that my resolution is to hide nothing that I know from him. Believe me, scholar, this is my resolution; and so here's to you a hearty draught, and to all that love us and the honest art of angling.

VEN. Trust me, good master, you shall not sow your seed in barren ground ; for I hope to return you an increase answerable to your hopes: but, however, you shall find me obedient and thankful and serviceable to my best ability.

PISC. 'Tis enough, honest scholar! come, let's to supper. Come, my friend Coridon, this trout looks lovely; it was twenty-two inches when it was taken! and the belly of it looked, some part of it, as yellow as a marigold, and part of it as white as a lily; and yet, methinks, it looks better in this good sauce.

CoRIDon. Indeed, honest friend, it looks well, and tastes well : I thank you for it, and so doth my friend Peter, or else he is to blame.

Peter. Yes, and so do I, we all thank you ; and when we have supped, I will get my friend Coridon to sing you a song for requital.

Cor. I will sing a song, if any body will sing another; else, to be plain with you, I will sing none: I am none of those that sing for meat, but for company: I say, "'Tis merry in hall, when men sing all."*

* Parody on the adage-

"It's merry in the hall

When beards wag all";

i.e. when all are eating. $-H$. 
PIsc. I'll promise you I'll sing a song that was lately made at my request by Mr. William Basse, one that hath made the choice songs of the Hunter in his Career, and of Tom of Bedlam, and many others of note; and this that I will sing, is in praise of angling.

CoR. And then mine shall be, the praise of a countryman's life : what will the rest sing of ?

Peter. I will promise you, I will sing another song in praise of angling to-morrow night ; for we will not part till then, but fish to-morrow, and sup together, and the next day every man leave fishing, and fall to his business.

Vex. 'Tis a match ; and I will provide you a song or a catch against then too, which shall give some addition of mirth to the company ; for we will be civil, and as merry as beggars.

PIsc. 'Tis a match, my masters ; let's e'en say grace, and turn to the fire, drink the other cup to wet our whistles, and so sing away all sad thoughts.

Come on, my masters, who begins? I think it is best to draw cuts, and avoid contention.

Peter. It is a match. Look, the shortest cut falls to Coridon. Cor. Well, then, I will begin, for I hate contention.

\section{Coriøon's Song.}

$\mathrm{Oh}$, the sweet contentment

The countryman doth find!

Heigh trolollie lollie loe,

Heigh trolollie lollie lee.

That quiet contemplation

Possesseth all my mind;

Then care a way,

And wend along with me.

For courts are full of flattery,

As hath too oft been tried;

Heigh trolollie lollie loe, etc.

The city full of wantonness,

And both are full of pride:

Then care away, etc.

But, $\mathrm{Oh}$ ! the honest country man

Speaks truly from his heart;

Heigh trolollie lollie loe, etc.

His pride is in his tillage,

His horses and his cart :

Then care away, etc.

Our clothing is good sheepsk ins,

Gray russet for our wives ;

Heigh trolollie lollie, loe, et . 
'Tis warmth, and not gay clothing,

That doth prolong our lives:

Then care away, etc.

The ploughman, though he labour hard,

Yet on the holiday,

Heigh trolollie lollie loe, etc.

No emperor so merrily

Doth pass his time away.

Then care away, etc.

To recompense our tillage,

The heavens afford us showers ;

Heigh trolollie lollie loe, etc.

And for our sweet refreshments

The earth affords us bowers:

Then care away, etc.

The cuckoo and the nightingale

Full merrily do sing,

Heigh trolollie lollie loe, etc.

And with their pleasant roundelays

Bid welcome to the spring:

Then care away, etc.

This is not half the happiness

The countryman enjoys;

Heigh trolollie lollie loe, etc.

Though others think they have as much,

Yet he that says so lies :

Then come away, turn

Countryman with me.-Jo. Chatrmill.*

Prsc. Well sung, Coridon; this song was sung with mettle, and it was choicely fitted to the occasion; I shall love you for it as long as I know you; I would you were a brother of the angle ; for a companion that is cheerful, and free from swearing and scurrilous discourse, is worth gold. I love such mirth as does not make friends ashamed to look upon one another next morning; nor men that cannot well bear it, to repent the money they spent when they be warmed with drink: and take this for a rule, you may pick out such times, and such companions, that you may make yourselves merrier for a little than a great deal of money; for, "Tis the company and not the charge, that makes the feast;" and such a companion you prove, I thank you for it.

But I will not compliment you out of the debt that I owe you; and therefore I will begin my song, and wish it may be so well liked.

* This poet's works Walton edited in his 90th year-that of his death.-ED. 


\section{The Angler's song.}

As inward lowe breeds outward taik,

The hound some praise, and some the hawk;

Some, better pleased with private sport,

Use tennis; some a mistress court : But these delights I neither wish Nor envy, while I freely fish.

Who hunts, doth oft in danger ride ;

Who hawks, lures oft both far and wide;

Who uses games, shall often prove

A loser ; but who falls in love Is fetter'd in fond Cupid's snare : My angle breeds me no such care.

Of recreation there is none

So free as fishing is alone ;

All other pastimes do no less

Than mind and body both possess;

$\mathrm{My}$ hand alone my work can do

So I can fish and study too.

I care not, I, to fish in seas-

Fresh rivers best my inind do please, Whose sweet calm course I contemplate,

And seek in life to imitate :

In civil bounds I fain would keep,

And for my past offences weep.

And when the timorous trout I wait To take, and he devours my bait, How poor a thing, sometimes I find, Will captivate a greedy mind ;

And when none bite, I praise the wise, Whom vain allurements ne'er surprise.

But yet, though while I fish I fast, I make good fortune my repast; And thereunto my friend invite, In whom I more than that delight :

Who is more welcome to my dish

Than to my angle was my fish.

As well content no prize to take, As use of taken prize to make : For so our Lord was pleased, when He fishers made fishèrs of men ;

Where (which is in no other game)

A man may fish aud praise His name. 
The first men that our Saviour dear

Did choose to wait upon Him here,

Bless'd fishers were, and fish the last

Food was that $\mathrm{He}$ on earth did taste :

I therefore strive to follow those

Whom $\mathrm{He}$ to follow Him hath chose.

Cor. Well sung, brother, you have paid your debt in good coin. We anglers are all beholden to the good man that made this song: come, hostess, give us more ale, and let's drink to him.

And now let's every one go to bed, that we may rise early : but first let's pay our reckoning, for I will have nothing to hinder me in the morning, for my purpose is to prevent the sun-rising.

Peter. A match. Come, Coridon, you are to be my bedfellow. I know, brother, you and your scholar will lie together. But where shall we meet to-morrow night? for my friend Coridon and I will go up the water towards Ware.

Pisc. And my scholar and I will go down towards Waltham.

Cor. Then let's meet here, for here are fresh sheets that smell of lavender; and I am sure we cannot expect better meat or better usage in any place.

Peter. 'Tis a match. Good night to everybody.

Pisc. And so say I.

VEN. And so say I.

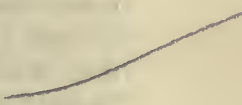

[fourth) 㫜av.]

Pisc. Good morrow, good hostess; I see my brother Peter is still in bed: come, give my scholar and me a morning drink, and a bit of meat to breakfast; and be sure to get a good dish of meat or two against supper, for we shall come home as hungry as hawks. Come; scholar, let's be going.

VEN. Well now, good master, as we walk towards the river give me direction, according to your promise, how I shall fish for a trout.

Pisc. My honest scholar, I will take this very convenient opportunity to do it.

The trout is usually caught with a worm or a minnow, which some call a penk, or with a fly, viz., either a natural or an artificial fly : concerning which three I will give you some observations and directions.

And, first, for worms : of these there be very many sorts : 
some breed only in the earth, as the earth-worm ; others of or amongst plants, as the dung-worm ; and others breed either out of excrements, or in the bodies of living creatures, as in the horns of sheep or deer; or some of dead flesh, as the maggot or gentle, and others.

Now these be most of them particularly good for particular fishes : but for the trout, the dew-worm, which some also call the lob-worm, and the brandling, are the chief; and especially the first for a great trout, and the latter for a less. There be also of lob-worms some called squirrel-tails, a worm that has a red head, a streak down the back, and a broad tail, which are noted to be the best, because they are the toughest and most lively, and live longest in the water: for you are to know that a dead worm is but a dead bait, and like to catch nothing, compared to a lively, quick, stirring worm : and for a brandling, he is usually found in an old dunghill, or some very rotten place near to it : but most usually in cow-dung, or hog's dung, rather than horse-dung, which is somewhat too hot and dry for that worm. But the best of them are to be found in the bark of the tanners, which they cast up in heaps after they have used it about their leather.

There are also divers other kinds of worms, which for colour and shape alter even as the ground out of which they are got; as the marsh-worm, the tag-tail, the flag-worm, the dock-worm, the oak-worm, the gilt-tail, the twachel, or lobworm," which of all others is the nost excellent bait for a salmon; and too many to name, even as many sorts as some think there be of several herbs or shrubs, or of several kinds of birds in the air ; of which I shall say no more, but tell you

* To avoid confusion, it may be necessary to remark, that the same kind of worm is, in different places, known by different names; thus the marsh and the meadow-worm are the same; and the lob-worm or twachel is also called the dew-worm, and the garden-worm; and the dock-worm is, in some places, called the flag-worm.

The tag-tail is found in March and April, in marled lands or meadows, after a shower of rain; or in the morning, when the weather is calm, and not cold.

To find the oak-worm, beat on an oak-tree that grows orer a high-way or bare place, and they will fall for you to gather,

To find the dock-worm, go to an old pond or pit, and pull up some of the flags; shake the roots in the water; and amongst the fibres that grow from the roots you will find little husks, or cases, of a reddish or yellowish colour; open these carefully with a pin, and take from them a little worm, pale yellow, or white, like a gentle, but longer and slenderer, with rows of feet down his belly, and a red head: this is the dock or flag-worm. An excellent bait for grayling, tench, bream, carp, roach, and dace.-H. 
that what worms soever you fish with are the better for being well scoured, that is, long kept before they be used : and in case you have not been so provident, then the way to cleanse and scour them quickly is to put them all night in water, if they be lob-worms, and then put them into your bag with fennel. But you must not put your brandlings above an hour in water, and then put them into fennel, for sudden use : but if you have time, and purpose to keep them long, then they be best preserved in an earthen pot, with good store of moss, which is to be fresh every three or four days in summer, and every week or eight days in winter; or, at least, the moss taken from them and clean washed, and wrung betwixt your hands till it be dry, and then put it to them again. And when your worms, especially the brandling, begins to be sick and lose of his bigness, then you may recover him by putting a little milk or cream, about a spoonful in a day, into them, by drops on the moss; and if there be added to the cream an egg beaten and boiled in it, then it will both fatten and preserve them long.* And note, that when the knot, which is near to the midclle of the brandling, begins to swell, then he is sick; and, if he be not well looked to, is near dying. And for moss, you are to note, that there be divers kinds of it, which I could name to you, but I will only tell you that that wlich is likest a buck's-horn is the best, except it be soft white moss, which grows on some heaths, and is hard to be found. And note, that in a very dry time, when you are put to an extremity for worms, walnut-tree leaves squeezed into water, or salt in water, to make it bitter or salt, and then that water poured on the ground, where you shall see worms are used to rise in the night, will make them to appear above ground presently. And you may take notice, some say that camphor, put into your bag with your moss and worms, gives them a strong and so tempting a smell, that the fish fare the worse and you the better for it.

* The following is also an excellent way: viz., Take a piece of hop-sack, or other very coarse cloth, and wash it clean, and let it dry; then wet in the liquor wherein beef has been boiled; but be careful that the beef is fresh, for salt will kill the worms, and wring it, but not quite dry; put the worms into this cloth, and lay them in an earthen pot, and let them stand from morning till night; then take the worms from the cloth, and wash it, and wet it again in some of the liquor: do thus once a day, and you may keep worms in perfect health, and fit for use, for near a month.

Observe that the lob-worm, marsh-worm, and red-worm, will bear more scouring than any others, and are better for long keeping.-H. 
And now I shall show you how to bait your hook with a worm, so as shall prevent you from much trouble, and tha loss of many a hook too, when you fish for a trout with a running-line, * that is to say, when you fish for him by hand at the ground : I will direct you in this as plainly as I can, that you may not mistake.

Suppose it be a big lob-worm, put your hook into him somewhat above the middle, and out again a little below the middle ; having so done, draw your worm above the arming of your hook : but note that at the entering of your hook it must not be at the head-end of the worm, but at the tail-end of him, that the point of your hook may come out toward the head-end, and having drawn him above the arming of your hook, then put the point of your hook again into the very head of the worm, till it come near to the place where the point of the hook first came out : and then draw back that part of the worm that was above the shank or arming of your hook, and so fish with it. And if you mean to fish with two worms, then put the second on before you turn back the hook's-head of the first worm : you cannot lose above two or three worms before you attain to what ] direct you; and having attained it, you will find it very useful, and thank me for it, for you will run on the ground without tangling.

Now for the Minnow or Penk : he is not easily found and caught till March, or in April, for then he appears first in the river; nature having taught him to shelter and hide himself, in the winter, in ditches that be near to the river; and there both to hide, and keep himself warm, in the mud, or in the weeds, which rot not so soon as in a running river, in which place if he were in winter, the distempered floods that are usually in that season would suffer him to take no rest, but carry him headlong to mills and weirs, to his confusion.

* The running-line, so called because it runs along the ground, is made of strong silk, which you may buy at the fishing-tackle shops (but I prefer hair, as being less apt to tangle), and is thus fitted up. About ten inches from the end, fasten a small cleft shot: then make a hole through a pistol or musket bullet, according to the swiftness of the stream you fish in; and put the line through it, and draw the bullet down to the shot: to the end of your line fasten an Indian grass, or silkworm-gut, with a large hook. Or you may, instead of a bullet, fix four large shot, at the distance of eight inches from the hook. The running-line is used for trout, grayling, and salmon-smelts; and is proper only for streams and rapid waters. See Cotton on Bottom-fishing, part ii. chap. xi. $-\mathrm{H}$. 
And of these minnows; first you are to know that the biggest size is not the best; and next, that the middle size and the whitest are the best; and then you are to know, that your minnow must be so put on your hook, that it must turn round when it is drawn against the stream; and, that it may turn nimbly, you must put it on a big-sized hook, as I shall now direct you, which is thus : put your hook in at his mouth, and out at his gill ; then, having drawn your hook two or three inches beyond or through his gill, put it again into his mouth, and the point and beard out at his tail; and then tie the hook and his tail about, very neatly, with a white thread, which will make it the apter to turn quick in the water: that done, pull back that part of your line which was slack when you did put your hook into the minnow the second time; I say, pull that part of your line back, so that it shall fasten the head, so that the body of the minnow shall be almost straight on your hook: this done, try how it will turn, by drawing it across the water or against the stream ; and if it do not turn nimbly, then turn the tail a little to the right or left hand, and try again, till it turn quick; for if not, you are in danger to catch nothing: for know that it is impossible that it should turn too quick; and you are yet to know, that in case you want a minnow, then a small loach or a stickle-hag, or any other small fish that will turn quick, will serve as well : and you are yet to know, that you may salt them, and by that means keep them ready and fit for use three or four days or longer ; and that of salt, bay-salt is the best.

And here let me tell you, what many old anglers know right well, that at some times, and in some waters, a minnow is not to be got; and therefore let me tell you, I have,which I will show you, - an artificial minnow," that will catch a trout as well as an artificial $\mathrm{fly}$, and it was made by a handsome woman that had a fine hand, and a live minnow lying by her: the mould or body of the minnow, was cloth, and wrought upon or over it thus with a needle: the back of it with very sad French green silk, and paler green silk towards the belly, shadowed as perfectly as you can imagine,

* Walton's method of making an artificial minnow is curious. How surprised he would be to see the artificial minnows, and other artificial fish baits of these days. No amateur need make them now, as they are to be had cheaply at all the tackle shops, well made, and in infinite variety. The best are those called "flexible," mate by William Flinn, of Worcester.-ED. 
just as you see a minnow ; the belly was wrought also with a needle, and it was a part of it white silk, and another part of it with silver thread; the tail and fins were of a quill which was shaven thin; the eyes were of two little black beads, and the head was so shadowed, and all of it so curiously wrought, and so exactly dissembled that it would beguile any sharpsighted trout in a swift stream. And this minnow I will now show you ; look, here it is, and, if you like it, lend it you, to have two or three made by it; for they be easily carried about an angler, and be of excellent use; for note, that a large trout will come as fiercely at a minnow as the highest mettled hawk doth seize on a partridge, or a greyhound on a hare. I have been told that a hundred and sixty minnows have been found in a trout's belly; either the trout had devoured so many, or the miller that gave it a friend of mine had forced them down his throat after he had taken him.

Now for flies, * which is the third bait wherewith trouts are usually taken. You are to know that there are so many sorts of flies as there be of fruits: I will name you but some of them; as the dun-fly, the stone-fly, the red-fly, the moorfly, the tawny-fly, the shell-fly, the cloudy or blackish-fly, the flag-fly, the vine-fly ; there be of flies, caterpillars, and cankerflies, and bear-flies; and indeed too many either for me to name, or for you to remember. And their breeding is so various and wonderful, that I might easily amaze myself, and tire you in a relation of them.

And, yet, I will exercise your promised patience by saying a little of the caterpillar, or the palmer-fly or worm; that by them you may guess what a work it were, in a discourse, but to run over those very many flies, worms and little living creatures with which the sun and summer adorn and beautify the river-banks and meadows, both for the recreation and contemplation of us anglers; pleasures which, I think, I myself enjoy more than any other man that is not of my profession.

Pliny holds an opinion, that many have their birth or being from a dew that in the spring falls from the leaves of trees; and that some kinds of them are from a dew left upon herbs

* The student must not pay any attention to what Walton says about artificial flies. He was not a fly-fisher; but he was a good bottom-fisher, and dibbed or daped well. Cotton was the fly-fisher, and when I come to the second part of this book, written by him, all that is necessary to be known about artificial flies shall be stated.-ED. 
or fiowers ; and others, from a dew left upon coleworts or cabbages : all which kinds of dews being thickened and condensed, are by the sun's generative heat most of them hatched, and in three days made living creatures: and these of several shapes and colours; some being hard and tough, some smooth and soft; some are horned in their head, some in their tail, some have none; some have hair, some none; some have sixteen feet, some less, and some have none; but as our Topsel* hath with great diligence observed, those which have none move upon the earth, or upon broad leaves, their motion being not unlike to the waves of the sea. Some of them, he also observes, to be bred of the eggs of other caterpillars, and that those in their time, turn to be butterflies; and again, that their eggs turn the following year to be caterpillars. And some affirm that every plant has his particular fly or caterpillar, which it breeds and feeds. I have seen, and may therefore affirm it, a green caterpillar or worm, as big as a small peascod, which had fourteen legs, eight on the belly, four under the neck, and two near the tail. It was found on a hedge of privet, and was taken thence and put into a large box, and a little branch or two of privet put to it, on which I saw it feed as sharply as a dog gnaws a bone; it lived thus five or six days, and thrived and changed the colour two or three times; but, by some neglect in the keeper of it, it then died, and did not turn to a fly: but if it had lived, it had doubtless turned to one of those flies that some call flies of prey, which those that walk by the rivers. may, in summer, see fasten on smaller flies, and, I think, make them their food. And 'tis observable, that as there be these flies of prey, which be very large, so there be others, very little, created, I think, only to feed them, and breed out of I know not what; whose life, they say, nature intended not to exceed an hour: and yet that life is thus made shorter by other flies, or by accident.

It is needless to tell you what the curious searchers into nature's productions have observed of these worms and flies: but yet I shall tell you what Aldrovandus, $\uparrow$ our Topsel, and others, say of the palmer-worm, or caterpillar, that whereas others content themselves to feed on particular herbs or leaves,

* In his " History of Serpents."

+ Ulysses Aldrovandus, a great physician and naturalist of Bologna; he wrote a hundred and twenty books on several subjects, and a treatise De I'iscibus, published at Frankfort, 1640.- $\mathrm{H}$. 
-for most think those very leaves that gave them life and shape, give them a particular feeding and nourishment, and that upon them they usually abide; yet he observes that this is called a pilgrim, or palmer-worm, for his very wandering life, and various food: not contenting himself, as others do, with any one certain place for his abode, nor any certain kind of herb or flower for his feeding, but will boldly and disorderly wander up and down, and not endure to be kept to a diet, or fixed to a particular place.

Nay, thevery colours of caterpillars are, as one has observed, very elegant and beautiful. I shall, for a taste of the rest, describe one of them; which I will, some time the next month, show you feeding on a willow-tree; and you shall find him punctually to answer this very description : his lips and mouth somewhat yellow; his eyes black as jet; his forehead purple ; his feet and hinder parts green ; his tail two-forked and black; the whole body stained with a kind of red spots, which run along the neck and shoulder-blade, not unlike the form of St. Andrew's cross, or the letter $\mathbf{X}$, made thus crosswise, and a white line drawn down his back to his tail ; all which add much beauty to his whole body. And it is to me observable, that at a fixed age this caterpillar gives over to eat, and towards winter comes to be covered over with a strange shell or crust, called an aurelia : and so lives a kind of dead life, without eating, all the winter $;^{*}$ and, as others of several kinds turn to be several kinds of flies and vermin the spring following, so this caterpillar then turns to be a painted butterfly.

Come, come, my scholar, you see the river stops our morning walk, and I will also here stop my discourse; only as we sit down under this honeysuckle hedge, whilst I look a line to fit the rod that our brother Peter hath lent you, I shall for a little confirmation of what I have said, repeat the observation of Du Bartas.

God, not contented to each kind to give, And to infuse the virtue generative,

By His wise power made many creatures breed Of lifeless bodies, without Venus' deed.

So the cold humour breeds the salamander, Who, in effect like to her birth's commander, With child with hundred winters, with her touch Quencheth the fire, though glowing ne'er so much.

* See Sir Francis Bacon's Exper., 728 and 90, in his Natural History.-H. 
So in the fire, in burning furnace springs

The fly Perausta, with the flaming wings ;

Without the fire it dies, in it it joys,

Living in that which all things else destroys.

So slow Boötos underneath him sees,

In th' icy islands, goslings hatch'd of trees,

Whose fruitful leaves, falling into the water,

Are turn'd, 'tis known, to living fowls soon after.

So rotten planks of broken ships do change

To barnacles. 0 transformation strange !

'Twas first a green tree, then a broken hull,

Lately a mushroom, now a flying gull.

VEN. O my good master, this morning-walk has been spent to my great pleasure and wonder : but I pray, when shall I have your direction how to make artificial flies, like to those that the trout loves best, and also how to use them?

Prsc. My honest scholar, it is now past five of the clock, we will fish till nine, and then go to breakfast. Go you to yon sycamore-tree and hide your bottle of drink under the hollow root of it; for about that time, and in that place, we will make a brave breakfast with a piece of powdered beef, and a radish or two that $I$ have in my fish-bag ; we shall, I warrant you, make a good, honest, wholesome, hungry breakfast, and I will then give you direction for the making and using of your flies; and in the mean time there is your rod, and line, and my advice is, that you fish as you see me do, and let's try which can catch the first fish.

VEN. I thank you, master, I will observe and practise your direction as far as I am able.

Pisc. Look you, scholar, you see I have hold of a good fish : I now see it is a trout, I pray put that net under him, and touch not my line, for if you do, then we break all.* Well done, scholar, I thank you.

Now for another. 'Trust me, I have another bite: come, scholar, come lay down your rod, and help me to land this as you did the other. So now we shall be sure to have a good dish for supper.

VEN. I am glad of that: but I have no fortune: sure, master, yours is a better rod and better tackling.

Pisc. Nay, then, take mine, and I will fish with yours.

* Nothing can be sounder than this advice. In playing a fish, the line must never be seized by the hand, but it must be shortened more or less according to circumstances, by winding it up by means of the winch or reel.-ED. 
Look you, scholar, I have another. Come, do as you did before. And now I have a bite at another. Oh me! he has broke all : there's half a line and a good hook lost.

VEN. Ay, and a good trout too.

PISc. Nay, the trout is not lost ; for pray take notice, no man can lose what he never had.

Ven. Master, I can neither catch with the first nor second angle: I have no fortume.

PIsc. Look you, scholar, T have yet another. And now, having caught three [two] brace of trouts, I will tell you a short tale as we walk towards our breakfast. A scholar, a preacher I should say, that was to preach to procure the approbation of a parish, that he might be their lecturer, had got from his fellow pupil the copy of a sermon that was first preached with great commendation by him that composed it: and though the borrower of it preached it, word for word, as it was at first, yet it was utterly disliked as it was preached by the second to his congregation: which the sermon-borrower complained of to the lender of it: and thus was answered: "I lent you, indeed, my fiddle, but not my fiddlestick; for you are to know that every one cannot make music with my words, which are fitted to my own mouth." And so, my scholar, you are to know, that as the ill-pronunciation or ill accenting of words in a sermon spoils it, so the ill carriage of your line, or not fishing even to a foot in a right place, makes you lose your labour : and you are to know, that though you have my fiddle, that is, my very rod and tacklings with which you see I catch fish, yet you have not my fiddlestick, that is, you yet have not skill to know how to carry your hand and line, or how to guide it to a right place : and this must be tar-ght you : for you are to remember, I told you angling is an art, either by practice or a long observation, or both. But take this for a rule, When you fish for a trout with a worm, let your line have so much, and not more lead than will fit the stream in which you fish; that is to say, more in a great troublesome stream than in a smaller that is quieter; as near as may be, so much as will sink the bait to the bottom, and keep it still in motion, and not more.

But now let's say grace and fall to breakfast: what say you, scholar, to the providence of an old angler? Does not this meat taste well? and was not this place well chosen to eat it? for this sycamore-tree will shade us from the sun's heat. 
VEx. All excellent good, and my stoinach excellent good too. And now I remember and find that true which devout Lessius" says: "That poor men, and those that fast often, have much more pleasure in eating than rich men and gluttons, that always feed before their stomachs are empty of their last meat, and call for more : for by that means they rob themselves of that pleasure that hunger brings to poor men." And I do seriously approve of that saying of yours, "that you would rather be a civil, well-governed, well-grounded, temperate, poor angler, than a drunken lord." But I hope there is none such ; however, I am certain of this, that I have been at very many costly dinuers that have not afforded me half the content that this has done, for which I thank God and you.

And now, good master, proceed to your promised direction for making and ordering my artificial fly.

Prsc. My honest scholar, I will do it; for it is a debt due unto you by my promise. And because you shall not think yourself more engagerl to me than indeed you. really are, I will freely give you such directions as were lately given to me by an ingenious brother of the angle, an honest man and a most excellent fly-fisher. $†$

You are to note, that there are twelve kinds of artificial made. flies to angle with on the top of the water. Note, by the way, that the fittest season of using these, is a bluster.ing windy day, when the waters are so troubled, that the natural fly cannot be seen, or rest upon them. The first is the dun-fly, in March : the body is made of dun wool; the wings, of the partridge's feathers. The second, is another dun-fly; the body of black wool : and the wings made of the black drake's feathers, and of the feathers under his tail. The third, is the stone-fly, in April : the body is made of black wool ; made yellow under the wings and under the tail

* Leonard Lessius, a very learned Jesuit, professor of divinity in the College of Jesuits at Louvain. He was born at Antwerp, 1554, and became very famous for his skill in divinity, civil law, matliematics, physic, and history: he wrote several theological tracts, and a book entitled, Hygiasticon, seu vera ratio valctudinis bonae, et vitac ad extremam senectutem conservandae. From this work of Lessius, it is probable the passage in the text is cited. He died in 1623.

$+W$ alton knew very little about fly-fishing. In this passage he admits his ignorance, by stating that the instructions he gives the scholar are derived from "an ingenious brother of the angle." The instructions are curious, but by no means useful. When we come to the second part of this work, written by Cotton, who was an excellent fly-fisher in his day, we shall treat of artificial flies, as now made, and show the modern method of using them.-ED. 
and so made with the wings of the drake. The fourth, is the ruddy-fly, in the beginning of May : the body made of red wool, wrapt about with black silk; and the feathers are the wings of the drake: with the feathers of a red capon also, which hangs dangling on his sides next to the tail. The fifth, is the yellow or greenish fly, in May likewise: the body made of vellow wool; and the wings made of the red cock's hackle or tail. The sixth is the black-fly, in May also: the body made of black wool, and lapped about with the herle of a peacock's tail : the wings are made of the wings of a brown capon, with his blue feathers in his head. The seventh, is the sad yellow-fly, in June: the body is made of black wool, with a yellow list on either side; and the wings taken off the wings of a buzzard, bound with black braked hemp. The eighth, is the moorish-fly; made with the body of duskish wool ; and the wings made of the blackish mail of the drake. The ninth, is the tawny-fly, good until the middle of June: the body made of tawny wool, the wings made contrary, one against the other, made of the whitish mail of the wild drake. 'The tenth, is the wasp-fly, in July; the body made of black wool, lapped about with yellow silk, the wings made of the feathers of the drake, or of the buzzard. The eleventh is the shell-fly, good: in mid-July; the body made of greenish wool, lapped about with the herle of a peacock's tail, and the wings made of the wings of the buzzard. The twelfth, is the dark drake-fly, good in August; the body made with black wool, lapped: about with black silk; his wings are made with the mail of the black drake, with a black head. Thus have you a jury of flies, likely to betray and condemn all the trouts in the river.*

I shall next give you some other directions for fly-fishing, such as are given by $\mathrm{Mr}$. Thomas Barker, $\uparrow$ a geutleman that

* The reader is not to adopt for his use any of these flies. By the word " mail," we must understand " mottled." The mottled featliers of the mallard of several hues are still used for the wings, legs, and tails of flies. There are few feathers more useful.-ED.

† I slaall also furnish you with " some other directions for fly-fishing, such as are given by Mr. Thomas Barker," who wrote before Walton a short treatise on Angling; and, as far as it goes, it is clever. He was no doubt a practical angler, almost a poacher, because he cares little how he catches fish, provided he does catch them. His patron was Edward Lord Montague, "a general" of the navy. Addressing himself to the noble lord, he thus begins :-

"Under favour, I will compliment, and put a case to your honour. I met with a man, and upon our discourse lie fell out with me, having a good weapon, but neither stomach nor skill; I say this man may come lome by Weepingcross; I will cause the clerk to toll his knell. It is the very like case to the 
hath spent much time in fishing; but I shall do it with a little variation.

First, let your rod be light, and very gentle; I take the best to be of two pieces: and let not your line exceed,especially for three or four links next to the hook,-I say, not exceed three or four hairs at the most, though you may fish a little stronger above, in the upper part of your line; but if you can attain to angle with one hair, you shall have more rises, and catch more fish. Now you must be sure not to cumber yourself with too long a line, as most do. And before. you begin to angle, cast to have the wind on your back; and the sun, if it shines; to be before you; and to fish down the stream; and carry the point or top of your rod downward, by which means, the shadow of yourself and rod too, will be least offensive to the fish ; for the sight of any shade amazes the fish, and spoils your sport-of which you must take a great care.

gentleman angler, that goeth to the river for his pleasure: this angler hath neither, judgment nor experience: he may come home lightly laden at his leisure.

"A man that goeth to the river for his pleasure, must understand, when he cometh there, to set forth his tackle. The first thing he must do, is to observe the wind and sun for day, the moon, the stars, and the wanes of the air for night, to set forth his tackles for day or night; and accordingly to go for his pleasure and some profit.

"Now I am determined to angle with the ground-baits, and set my tackles to my rod, and go to my pleasure. I begin at the uppermost part of the stream, carrying my line with an upright hand, feeling my plummet running truly on the ground some ten inches from the hook, plumming my line according to the swiftness of the stream I angle in ; for one plummet will not serve for all streams: for the true angling is, that the plummet run truly on the ground.

"My lord sent to me, at sun going down, to provide lim a good dish of trouts against the next morning, by six o'clock. I went to the door to see how the wanes of the air were like to prove. I returned answer, that I doubted not, God willing, but to be provided at the time appointed. I went presently to the river, and it proved very dark: I threw out a line of three silks and three hairs twisted, for the uppermost part; and a line of two hairs and two silks twisted, for the lower part-with a good large hook. I baited my hook with two lob-worms, the four ends hanging as meet as I: could guess them in the dark. I fell to angle. It. proved very dark, so that I had good sport; angling with the lob-worms the same as $I$ do with the flies, on the top of the water:-You will hear the fish rise at the top of the water; then, you must loose a slack line down to the bottom, as nigh as you can guess; then hold your line straight, feeling the fish bite; give time, there is no doubt of losing the fish, for there is not one amongst twenty but doth gorge the bait: the least stroke you can strike fastens the hook, and makes the fish sure. letting the fish. take a turn or two; you may take him up with your hands. The night began to alter and grow somewhat lighter; I took off the lob-worms, and set to my rod a white palmer fly made of a large hook; I had good sport for the time, until it grew lighter; so I took off the white palmer, and set to a red palmer, made of a large hook; I had good sport until it grew very light: then I took 
In the middle of March, till which time, a man should not, in honesty, catch a trout-or in April, if the weather be dark, or a little windy or cloudy, the best fishing is with the palmer-worm, of which I last spoke to you ; but of these there be divers kinds, or at least of divers colours; these and the May-fly are the ground of all fly-angling, which are to be thus made :

First, you must arm your hook with the line in the inside of it, then take your scissors, and cut so much of a brown mallard's feather, as in your own reason will make the wings of it, you having withal regard to the bigness or littleness of your hook; then lay the outmost part of your feather next to your hook, then the point of your feather next the shank of your hook; and having so done, whip it three or four times about the hook with the same silk with which your hook was armed; and, having made the silk fast, take the hackle of a cock or capon's neck, or a plover's top, which is usually

off the red palmer and set to a black palmer; I had good sport, and made up the dish of fish. So I put up my tackles, and was with my lord at his time appointed for the service.

"These three flies, with the help of the lob-worms, serve to angle all the year for the night; observing the times-as I have showed you-in this niglitwork; the white lly for darkness, the red fly in medio, and the black fly for lightness. This is the true experience for angling in the night; which is the surest angling of all, and killeth the greatest trouts. Your lines may be strong, but must not be longer than your rod.

"Now, having taken a good dish of trouts, I presented them to my lord. He having provided good company, commanded me to turn cook, and dress them for dinner-

"There comes an honest gentleman, a familiar friend, to me-he was an angler-begins to compliment with me, and asked me how $I$ did? when $I$ had been angling? and demanded, in discourse, what was the reason I did not relate in my book the dressing of his dish of fisll, which he loved? I pray you, sir, what dish of trouts was that? He said it was a dish of close-boiled trouts, buttered with eggs. MIy answer was to him, that every scullion dresseth that dish against his will, because he cannot calvor them. I will tell you, in short: Put your trouts into the kettle when the kettle is set to the fire, and let them boil gently, as many cooks do; and they shall boil close enough; which is a good dish, buttered with eggs, good for plouglimen, but not for the palate. Sir, I hope I have given satisfaction,"

['This Mr. Thomas Barker was no doubt an excellent angler. He was the first known inventor of what are called night-flies or moths. And he used them on the right principle, riz. : in darkness, a very light bodied and lightwinged fly; when only moderately dark, a yellow fly; and when becoming to get dark, a brown-bodied fly. Hence we moderns have the flies called the brown, the yellow, and the white moth. If I mistake not, Barker was the first to make use of trout or salmon roe as a bait for fish, but he used it in a raw state. It is now a very common and a very deadly bait ; but it is used in a preserved state, and very properly, as being, when so, more killing and far more convenient than when raw.]-Ev. 
better; take off the one side of the feather, and then take the hackle, silk, or crewel, gold or silver thread, make these fast at the bent of the hook, that is to say, below your arming; then you must take the hackle, the silver or gold thread, and work it up to the wings, shifting or still removing your finger, as you turn the silk about the hook; and still looking at every stop or turn, that your gold, or what materials soever you make your fly of do lie right and neatly; and if you find they do so, then, when you have made the head, make all fast and then work your hackle up to the head, and make that fast : and then with a needle or pin divide the wing into two, and then with the arming silk whip it about crossways betwixt the wings, and then with your thumb you must turn the point of the feather towards the bent of the hook, and then work three or four times about the shank of the hook, and then view the proportion, and if all be neat and to your liking, fasten.

I confess, no direction can be given to make a man of a dull capacity able to make a fly well : and yet I know, this, with a little practice, will help an ingenious angler in a good degree; but to see a fly made by an artist in that kind, is the best teaching to make it. And then an ingenious angler may walk by the river and mark what flies fall on the water that day, and catch one of them, if he sees the trouts leap at a fly of that kind; and then having always hooks ready hung, with him, and having a bag always with him, with bear's hair, or the hair of a brown or sad-coloured heifer, hackles of a cock or capon, several coloured silk and crewel to make the body of the fly, the feathers of a drake's head, black or brown sheep's wool, or hog's wool or hair, thread of gold and of silver; silk of several colours (especially sad-coloured), to make the fly's head: and there be also other coloured feathers, both of little birds and of speckled fowl:" I say, having those

* Sir John Hawkins, at this point of his edition of Walton, gives, in a note, a list of the materials used in his time-nearly a hundred years ago-for flymaking. Some of the materials mentioned are proper, the others not so. The following list contains all that is necessary for dressing such flies as will capture trout, grayling, chub, dace, and roach. For plain, dully transparent wings, the fibres of the starling's wing-feather are the best, and therefore far more generally used; for small light transparent wings, fibres from the feathers of the lark's wings ; for reddish wings, the land-rail's and red-wing's feathers from the wing and from under the wing : for mottled wings, the wing-feathers of woodcock, partridge, and hen pheasant, and the brown and grey mottled feathers of the mallard, and tail-feathers of the hen and cock pheasant; for legs, all sorts 
with him in a bag, and trying to make a fly, though he miss at first, yet shall he at last hit it better, even to such a perfection as none can well teach him; and if he hit to make his fly right, and have the luck to hit also where there is store of trouts, a dark day, and a right wind, he will catch such store of them, as will encourage him to grow more and more in love with the art of fly-making.

VEN. But, my loving master, if any wind will not serve, then I wish I were in Lapland, to buy a good wind of one of the honest witches, that sell so many winds there, and so cheap.

PISc. Marry, scholar, but I would not be there, nor indeed from under this tree: for look how it begins to rain ; and by the clouds, if I mistake not, we shall presently have a smoking shower; and therefore sit close; this sycamore tree will shelter us : and I will tell you, as they shall come into my mind, more observations of fly-fishing for a trout.

But first, for the wind; you are to take notice, that of the winds, the south wind is said to be the best. One observes, that -when the wind is south, It blows your bait into a fish's mouth.

Next to that, the west wind is believed to be the best : and having told you that the east wind is the worst, I need not.

of cock's hackles, duns, reds, browns, whites, and blacks, naturally, and dyed yellow, green, olive, orange, purple ; for legs also, grouse's back-feathers, wren's tail, golden plover back-feathers, pewit's topping, peacock's harl of different hues, black ostrich harl (harl is the fibre of the long tail-feathers of the peacock, \&cc.), and a few others. These feathers, or at least a few of them, are often used to make the bodies of flies, and frequently to rib them.

The best materials for dubbing, that is for making the bodies and occasionally the legs, are mohair and pig's wool, dyed of many colours. They best suit the imitation of large-bodied flies, and resist the water better than any other substance used, except seal's fur, which dyed diversely, is an excellent dubbing. Floss silk of every hue is used for bodies, and various sorts of furs, bear's, monkey's, spaniel's, mole's, water-rat's, hare's pole and ear, martin's sellow fur, and a few other sorts. For tipping at the tails of flies, and for ribbing the bodies, you must use silver and gold twist and tinsel. All sorts, sizes, and colours, of tying silk are indispensable, and they must be well waxed when used. Varnish is necessary for the whipping of the hook and gut, and for the finishing of the heads of flies. All slip-knots should be touched with varnish to prevent them undoing. Some flies have two whisks or tails, some three. To imitate them, the fibre of the mallard's mottled feather is much used, and so are hairs, particularly the dark ones found on bear skins, and on the faces of rabbits, cats, \&c. The whisks or tails of flies should generally be the colour either of the bodies or wings. The fibres of the feathers used for the wings will frequently suit for the tails.-ED. 
tell you which wind is the best in the third degree : and yet (as Solomon observes), that "he that considers the wind shall never sow," so he that busies his head too much about them, if the weather be not made extreme cold by an east wind, shall be a little superstitious : for as it is observed by some, that "there is no good horse of a bad colour," so I have observed, that if it be a cloudy day, and not extreme cold, let the wind set in what corner it will and do its worst, I heed it not. And yet take this for a rule, that I would willingly fish standing on the lee-shore : and you are to take notice, that the fish lies or swims nearer the bottom, and in deeper water, in winter than in summer; and also nearer the bottom in any cold day, and then gets nearest the lee side of the water.

But I promised to tell you more of the fly-fishing for a trout, which I may have time eqnough to do, for you see it rains May-butter. First, for a May-fly, you may make his body with greenish-coloured crewel or willowish colour; darkening it in most places with waxed silk, or ribbed with black hair, or some of them ribbed with silver thread; and such wings for the colour, as you see the fly to have at that season, nay, at that very day, on the water. Or you may make the oak-fly, with an orange tawny, and black ground, and the brown of a mallard's feather for the wings ; ; and you are to know; that these two are most excellent flies, that is, the May-fly and the oak-fly. And let me again tell you that you keep as far from the water as you can possibly, whether you fish with a fly or worm, and fish down the stream : and when you fish with a fly, if it be possible, let no part of your line touch the water, + but your fly only ; and be still moving your fly upon the water, or casting it into the water, you yourself being also always moving down the stream.

Mr. Barker commends several sorts of the palmer-flies, not only those ribbed with silver and gold, but others that have their bodies all made of black, or some with red, and a red

* The best way to imitate this excellent fly is thus shown in my " Handbook of Angling." Wings,-Partridge's wing-feather dressed of a full size, and to lie flat. Body, bright yellow molıair, ribbed with dark brown silk, and tipped with gold twist. Legs, a honey-dun hackle wound twice under the wings. Hook, No. 9 and 10.-LD.

$\dagger$ This is impossible, unless you dib with the artificial as with the natural fly, which is never practised. The method of throwing or casting is more particularly treated of in the notes on part 2, cliap. v.-FD. 
hackle; you may also make the hawthorn-fly, which is all black, and not big, but very small, the smaller the better ; or the oak-fly, the body of which is orange colour and black crewel, with a brown wing; or a fly made with a peacock's feather is excellent in a bright day. You must be sure you want not in your magazine-bag, the peacock's feather, and grounds of such wool and crewel as will make the grasshopper ; and note, that usually the smallest flies are the best ; and note also, that the light fly does usually make most sport in a dark day, and the darkest and least fly in a bright or clear day; and lastly, note, that you are to repair upon any occasion to your magazine-bag, and upon any occasion, vary and make them lighter or sadder, according to your fancy, or the day.

And now I-shall tell you, that the fishing with a natural fly is excellent, and affords much pleasure. They may be found thus : the May-fly, usually in and about that month, near to the river side, especially against rain : the oak-fly, on the butt or body of an oak or ash, from the beginning of May to the end of August ; it is a brownish fly and easy to be found, and stands usually with his head downward, that is to say, towards the root of the tree : the small black-fly, or hawthorn$\mathrm{fly}$, is to be had on any hawthorn bush after the leaves be come forth. With these and a short line (as I showed, to angle for a chub), you may dape or dop, and also with a grasshopper, behind a tree, or in any deep hole ; still making it to move on the top of the water, as if it were alive, and still keeping yourself out of sight, you shall certainly have sport if there be trouts; yea, in a hot day, but especially in the evening of a hot day, you will have sport.

And now, scholar, my direction for fly-fishing is ended with this shower, for it has done raining; and now look about you, and see how pleasantly that meadow looks; nay, and the earth smells as sweetly too. Come, let me tell you what holy Mr. Herbert says of such days and flowers as these; and then we will thank God that we enjoy them, and walk to the river and sit down quietly, and try to catch the other brace of trouts.

Sweet day, so cool, so calm, so bright, The bridal of the earth and sky,

Sweet dews shall weep thy fall to-night-

For thou must die. 
Sweet rose, whose hue, angry and brave,

Bids the rash gazer wipe his eye,

Thy root is ever in its grave-

And thou must die.

Sweet spring, full of sweet days and roses,

A box where sweets compacted lie ;

My music shows you have your closes-

And all must die.

Only a sweet and virtuous soul,

Like season'd timber, never gives ;

But when the whole world turns to coal,

Then chiefly lives.

VEN. I thank you, good master, for your good direction for fly-fishing, and for the sweet enjoyment of the pleasant day, which is so far spent without offence to God or man : and I thank you for the sweet close of your discourse with Mr. Herbert's verses, who, I have heard, loved angling; and I do the rather believe it, because he had a spirit suitable to anglers, and to those primitive Christians that you love, and have so much commended.

Pisc. Well, my loving scholar, and I am pleased to know that you are so well pleased with my direction and discourse.

And since you like these verses of Mr. Herbert's so well, let me tell you what a reverend and learned divine that professes to imitate him (and has iudeed done so most excellently) hath writ of our book of Common Prayer; which I know you will like the better, because he is a friend of mine, and I am sure no enemy to angling.

What! Prayer by the Book? and Common? Yes! why not?

The spirit of grace

And supplication

Is not left free alone

For time and place,

But manner too: to read, or speak, by rote,

Is all alike to him that prays

In's heart, what with his mouth he says.

They that in private, by themselves alone,

Do pray, may take

What liberty they please,

In choosing of the ways

Wherein to make

Their soul's most intimate affections known

To him that sees in secret, when

They're inost conceal'd from other men. 
But he that unto others leads the way

In public prayer,

Should do it so

As all that hear may know

They need not fear

To tune their hearts unto his tongue, and say,

Amen; not doubt they were betrayed

To blaspheme, when they meant to have pray'd.

Devotion will add life unto the letter : And why should not

That which authority

Prescribes, esteemed be

Advantage got?

If the prayer be good, the commoner the better ;

Prayer in the Church's words as well

As sense, of all prayers bears the bell.-Crr. Harvie.

And now, scholar, I think it will be time to repair to our angle-rods, which we left in the water to fish for themselves: and you shall choose which shall be yours; and it is an even lay, one of them catches.

And, let me tell you, this kind of fishing with a dead rod, and laying night-hooks, are like putting money to use; for they both work for the owners, when they do nothing but sleep, or eat, or rejoice; as you know we have done this last hour, and sat as quietly and as free from cares under this sycamore, as Virgil's Tityrus and his Melibœus did under. their broad beech-tree. No life, my honest scholar, no life so happy and so pleasant, as the life of a well-governed angler, for when the lawyer is swallowed up with business, and the statesman is preventing or contriving plots, then we sit on cowslip-banks, hear the birds sing, and possess ourselves in as much quietness as these silent silver streams, which we now see glide so quietly by us. Indeed, my good scholar, we may say of angling, as Dr. Boteler said of strawberries, " Doubtless God could have made a better berry, but doubtless God never did ;" and so, if I might be judge, "God never did make a more calm, quiet, innocent recreation, than angling."

I'll tell you, scholar, when I sat last on this primrose bank, and looked down these meadows, I thought of them, as Charles the emperor did of the city of Florence, "That they were too pleasant to be looked on, but only on holidays." As I then sat on this very grass, I turned my present thoughts into verse : 'twas a wish, which I'll repeat to you.*

* We have here little less than Walton's own word for it, that the following 


\section{The Angler's carist;.}

I in these flowery meads would be :

These crystal streams should solace me ;

To whose harmonious bubbling noise

I with my angle would rejoice,

Sit here, and see the turtle dove

Court his chaste mate to acts of love :

Or, on that bank, feel the west wind

Breathe health and plenty : please my mind,

To see sweet dewtrops kiss these flowers,

And then wash'd off by April showers;

Here, hear ny Kenna* sing a song ; [" "Like Hermit Poor."]

There, see a blackbird feed her young,

Or a leverock build her nest :

Here, give my weary spirits rest,

And raise my low-pitch'd thoughts above

Earth, or what poor mortals love :

Thus, free from lawsuits and the noise

Of princes' courts, I would rejoice ;

Or, with my Bryant and a book,

Loiter long days near Shawford brook ; $\ddagger$

There sit by him, and eat my meat;

There see the sun both rise and set;

There bid good morning to next day;

There meditate my time away;

And angle on, and beg to have

A quiet passage to a welcome grave.

beautiful stanzas are of his writing. That he had in his mind a vein of poetry is noted in our.life of him; to which let me add, that the name of his supposed mistress, "lienna," seems clearly to be formed from the maiden-name of his. wife, which was Ken.-H.

* We see, by the author's reference to the margin, that he wishes to hear Kenna, his mistress, sing the song, "Like Hermit Poor." This song was set to. music by Nich. Laneare, an eminent master of Walton's time.

There is no doubt that this song was (and probably with Mrs. Walton) a favourite one; for, some years after the Restoration, the three first words of it were become a phrase. The affected writer of the "Life of the Lord Keeper Guildford," page 212 of that book, speaking of Sir Job Charleton, then chiefjustice of Chester, says, he wanted to speak with the king; and went to Whitehall; where, returning from his walk in St. James's-park, he must pass; and there he sat him down "like hermit poor."-H.

$\dagger \mathrm{A}$ friend conjectures this to be the name of his favourite dog. $-\mathrm{H}$.

¥ Shawford-brook, part of the river Sow, running through the very land which Walton bequeathed in his will to the corporation of Stafford to find coals for the poor; the right of fishery in which attaches to this little estate. The louse, described by Walton in his will, is now divided. The brook is a beautiful winding stream, and the situation such as would be likely to create admiration in a mind like Walton's.-H. 
When I had ended this composure, I left this place, and saw a brother of the angle sit under that honeysuckle hedge, one that will prove worth your acquaintance: I sat down by him, and presently we met with an accidental piece of merriment, which I will relate to you ; for it rains still.

On the other side of this very hedge sat a gang of gipsies, and near to them sat a gang of beggars. The gipsies were then to divide all the money that had been got that week, either by stealing linen or poultry, or by fortune-telling, or legerdemain, or indeed by any other sleights and secrets belonging to their mysterious government. And the sum that was got that week proved to be but twenty and some odd shillings. The odd money was agreed to be distributed amongst the poor of their own corporation; and for the remaining twenty shillings, that was to be divided unto four gentlemeu gipsies, according to their several degrees in their commonwealth.

And the first or chiefest gipsy was, hy consent, to have a third part of the $20 s$., which all men know is $6 s .8 d$.

The second was to have a fourth part of the $20 s$., which all men know to be $5 s$.

The third was to have a fifth part of the 20 s., which all men know to be $4 s$.

The fourth and last gipsy was to have a sixth part of the $20 s$., which all men know to be $3 s$. $4 d$.

As for example,

3 times $6 s .8 d$. is $20 s$.

And so is 4 times $5 s$. . 20 s.

And so is 5 times $4 s$. . 20s.

And so is 6 times $3 s .4 d$. . 20s.

And yet he that divided the money was so very a gipsy, that though he gave to every one these said sums, yet he kept 1s. of it for himself.

$\begin{array}{ccc}\text { As for example, } & s . & d . \\ & 6 & 8 \\ & 5 & 0 \\ 4 & 0 \\ & 3 & 4 \\ \text { make but } & 19 & 0\end{array}$

But now you shall know, that when the four gipsies saw that he had got $1 s$. by dividing the money, though not one of them knew any reascn to demand more, yet, like lords and 
courtiers, every gipsy envied him that was the gainer, and wrangled with him, and every one said the remaining shilling belonged to him : and so they fell to so high a contest about it, as none that knows the faithfulness of one gipsy to another will easily believe; only we that have lived these last twenty years, are certain that money has been able to do much mischief. However, the gipsies were too wise to go to law, and did therefore choose their choice friends Rook and Shark, and our late English Gusman," to be their arbitrators and umpires; and so they left this honeysuckle hedge, and went to tell fortunes, and cheat, and get more money and lodging in the next village.

When these were gone, we heard a high contention amongst the beggars, whether it was easiest to rip a cloak, or to unrip a cloak. One beggar affirmed it was all one. But that was denied by asking her if doing and undoing were all one. Then another said 'twas easiest to unrip a cloak, for that was to let it alone. But she was answered by asking her, how she unripped it, if she let it alone: and she confessed herself mistaken. These and twenty such like questions were proposed, and answered with as much beggarly logic and earnestness, as was ever heard. to proceed from the mouth of the most pertinacious schismatic: and sometimes all the beggars, whose number was neither more nor less than the poet's nine muses, talked altogether about this ripping and unripping, and so loud that not one heard what the other said: but at last one beggar craved audience, and told them that old father Clause, whom Ben Jonson in his "Beggar's Bush," † created king of their corporation, was to lodge at an alehouse called "Catch-her-by-the-way," not far from Waltham Cross, and in the high road towards London; and he therefore clesired them to spend no more time about that and such like questions, but refer all to father Clause at night, for he was an upright judge, and in the meantime draw cuts, what song should be next sung, and who should sing it. They all agreed to the motion; and the lot fell to her that was the youngest

* Alluding to a work that appeared a few years before, entitled "The English Gusman ; or, The History of that Unparalleled 'I'hief, James Hind," written by George Fidge. 4to. London, 1652. Hind made a considerable figure at the time of the great rebellion, and fought, both at Worcester and Warrington, on the king's side. He was arrested by order of the Parliament in 1651 . Rook and Shark, imaginary associates of the English Gusman.-H.

+ This comedy was not written by Jonson, but by Beaumont and Fletcher. 
and veriest virgin of the company. And she sung Frank Davison's song, which he made forty years ago ; and all the others of the company joined to sing the burthen with her. The ditty was this: but first the burthen :

Bright shines the sun; play, beggars play!

Here's scraps enough to serve to-day.

What noise of viols is so sweet

As when our merry clappers ring?

What mirth doth want when beggars meet?

A beggar's life is for a king,

Eat, drink, and play, sleep when we list,

Go where we will-so stocks be miss'd.

Bright shines the sun; play, beggars, play !

Here's scraps enough to serve to-day.

The world is ours, and ours alone ;

For we alone have world at will.

We purchase not-all is our own ;

Both fields and streets we beggars fill.

Bright shines the sun ; play, beggars, play !

Here's scraps enough to serve to-day.

A hundred herds of black and white

Upon our gowns securely feed;

And yet if any dare us bite,

He dies, therefore, as sure as creed.

Thus beggars lord it as they please,

And only beggars live at ease.

Bright shines the sun ; play, beggars, play!

Here's scraps enough to serve to-day.

VeN. I thank you, good master, for this piece of merriment, and this song, which was well humoured by the maker, and well remembered by you.

PIsc. But, I pray, forget not the catch which you promised to make against night; for our countryman, honest Coridon, will expect your catch, and my song, which I must be forced to patch up, for it is so long since I learnt it, that I have forgotten a part of it. But, come, now it hath done raining, let's stretch our legs a little in a gentle walk to the river, and try what interest our angles will pay us for lending them so long to be used by the trouts; lent them, indeed, like usurers, for our profit and their destruction.

VEN. Oh me! look you, master, a fish ! a fish ! Oh, alas, master, I have lost her !

PIsc. Ay, marry, sir, that was a good fish indeed: if I had had the luck to have taken up that rod, then 'tis twenty to 
one he should not have broke my line by running to the rod's end, as you suffered him. I would have held him within the bent of my rod (unless he had been fellow to the great trout that is near an ell long, which was of such a length and depth that he had his picture drawn, and now is to be seen at mine host Rickabie's, at the George, in Ware), and it may be by giving that very great trout the rod, that is, by casting it to him into the water, I might have caught him at the long run; for so I use always to do when I meet with an overgrown fish; and you will learn to do so too hereafter: for I tell you, scholar, fishing is an art; or, at least, it is an art to catch fish.

VEN. But, master, I have heard that the great trout you speak of is a salmon.

PISc. Trust me, scholar, I know not what to say to it. There are many country people that believe hares change sexes every year : and there be very many learned men think so too, for in their dissecting them they find many reasons to incline them to that belief. And to make the wonder seem yet less, that hares change sexes, note, that Doctor Mer. Casaubon affirms in his book of credible and incredible things, that Gaspar Peucerus, a learned physician, tells us of a people that once a year turn wolves, partly in shape and partly in conditions. And so, whether this were a salmon when he came into the fresh water, and his not returning into the sea hath altered him to another colour or kind, I am not able to say : but I am certain he hath all the signs of being a trout both for his shape, colour, and spots; and yet many think he is not.

VEN. But, master, will this trout which I had hold of die? for it is like he hath the hook in his belly.

PIsc. I will tell you, scholar, that unless the hook be fast in his very gorge, 'tis more than probable he will live; and a little time, with the help of the water, will rust the hook, and it will in time wear away; as the gravel doth in the horsehoof, which only leaves a false quarter.

And now, scholar, let's go to my rod. Look you, scholar, I have a fish too, but it. proves a logger-headed chub; and this is not much amiss, for this will pleasure some poor body, as we go to our lodging to meet our brother Peter, and honest Coridon. Come, now bait your hook again, and lay it into the water, for it rains again: and we will even retire to the sycamore tree, and there I will give you more directions concerning fishing; for I would fain make you an artist. 
Ven. Yes, good master, I pray let it be so.

Pisc. Well, scholar, now we are sat down and are at ease, I shall tell you a little more of trout-fishing, before I speak of salmon, which I purpose shall be next, and then of the pike or luce.

You are to know there is night as well as day-fishing for a trout, and that in the night the best trouts come out of their holes: and the manner of taking them is, on the top of the water, with a great lob or garden-worm, or rather two, which you are to fish within a place where the waters run somewhat quietly, for in a stream the bait will not be so well discerned. I say, in a quiet or dead place, near to some swift: there draw your bait over the top of the water, to and fro; and if there be a good trout in the hole, he will take it, especially if the night be dark; for then he is bold, and lies near the top of the water, watching the motion of any frog, or waterrat, or mouse that swims between him and the sky: these he hunts after if he sees the water but wrinkle or move in one of these dead holes, where these great old trouts usually lie near to their holds; for you are to note, that the great old trout is both subtle and fearful, and lies close all day, and does not usually stir out of his hold, but lies in it as close in the day as the timorous hare does in her form, for the chief feeding of either is seldom in the day, but usually in the night, and then the great trout feeds very boldly.

And you must fish for him with a strong line, and not a little hook ; and let him have time to gorge your hook, for he does not usually forsake it, as he oft will in the day-fishing. And if the night be not dark, then fish so with an artificial fly of a light colour, and at the snap : nay, he will sometimes rise at a dead mouse, or a piece of cloth, or anything that seems to swim across the water, or to be in motion. This is a choice way, but I have not often used it, because it is void of the pleasures that such days as these, that we two now enjoy, afford an angler.

And you are to know, that in Hampshire, which I think exceeds all England for swift, shallow, clear, pleasant brooks, and store of trouts, they used to catch trouts in the night, by the light of a torch or straw, which, when they have discovered, they strike with a trout-spear, or other ways. This kind of way they catch very many; but I would not believe it till I was an eye-witness of it, nor do I like it now I have seen it. 
VEN. But, master, do not trouts see us in the night?

Pisc. Yes, and hear and smell too, both then and in the day-time : for Gesner observes, the otter smells a fish forty furlongs off him in the water: and that it may be true, seems to be affirmed by Sir Francis Bacon, in the eighth century of his "Natural History," who there proves that water may be the medium of sounds, by demonstrating it thus: "that if you knock two stones together very deep under the water, those that stand on a bank near to that place may hear the noise without any diminution of it by the water." He also offers the like experiment concerning the letting an anchor fall, by a very long cable or rope, on a rock, or the sand within the sea. And this being so well observed and demonstrated as it is by that learned man, has made me to believe that eels unbed themselves and stir at the noise of thunder; and not only, as some think, by the motion or stirring of the earth, which is occasioned by that thunder.

And this reason of Sir Francis Bacon, Exper. 792, has made me crave pardon of one that I laughed at, for affirming that he knew carps come to a certain place in a pond, to be fed, at the ringing of a bell, or the beating of a drum ; and however, it shall be a rule for me to make as little noise as I can when I am fishing, until Sir Francis Bacon be confuted, which I shall give any man leave to do.*

* That fish hear, is confirmed by the authority of late writers. Swammerdam asserts it, and adds, that "they have a wonderful labyrinth of the ear for that purpose." See Swammerdam on Insects, edit. London, 1758, p. 50. A clergyman, a friend of mine, assures me, that at the Abbey of St. Bernard, near Antwerp, he saw carp come at the whistling of the feeder.-H.

[With respect to the organs of hearing, and the power of hearing in fish, I consulted Mr. Erasmus Wilson, one of the most eminent anatomists and physiologists now alive, and the following is his opinion:- "There is nothing in the exterior head of the fish to indicate that it is provided with an ear. In the higher animals, the mechanical apparatus of hearing consists of an internal and an external portion: in fishes, the internal portion alone exists, and is hardly inferior in perfection of form and structure, to that of creatures placed. higher in the animal scale. The nerves distributed to the organs of hearing are of large size, and the vital apparatus, or portion of brain, from which the former proceed, is considerable. There exists, however, this important difference between the organ of hearing of terrestrial animals and fishes, viz., that the ear in the former is organized for the reception of the more delicate vibrations of the atmosphere, while in the latter it is adapted to the rude oscillations of a denser element. We may make this difference apparent by the following simple illustration. The impulse occasioned to the air by the ticking of a watch is so weak, as to be indistinctly heard when the watch is brought close to the ear; but if we convey the watch to a greater distance from the ear and press. it against the teeth, we hear the ticking with remarkable distinctness. In the language of science, solid and dense bodies vibrate with greater intensity than: 
And, lest you may think him singular in his opinion, I will tell you, this seems to be believed by our learned Dr. Hakewill, who, in his "Apology of God's Power and Providence," fol. 360, quotes Pliny to report that one of the emperors had particular fish-ponds, and in them several fish that appeared and came when they were called by their particular names: and St. James tells us, chap. iii. 7, that all things in the sea have been tamed by mankind. And Pliny tells us, lib. ix. 35, that Antonia, the wife of Darsus, had a lamprey, at whose gills she hung jewels or ear-rings; and that others have been so tender-hearted as to shed tears at the death of fishes which they have kept and loved. And these observations, which will to most hearers seem wonderful, seem to have a further confirmation from Martial, lib. iv. Epigr. 30, who writes thus :

Piscator, fuge ; ne nocens, etc.

Angler! wouldst thou be guiltless ? then forbear ;

For these are sacred fishes that swim here,

Who know their sovereign, and will lick his hand ;

Than which none's greater in the world's command :

Nay more, they've names, and, when they called are,

Do to their several owners' call repair.

All the further use that I shall make of this shall be, to advise anglers to be patient and forbear swearing, lest they be heard, and catch no fish.

And so I shall proceed next to tell you, it is certain, that certain fields near Leominster, a town in Herefordshire, are observed to make the sheep that graze upon them more fat than the next, and also to bear finer wool; that is to say that that year in which they feed in such a particular pasture, they

lighter media, such as the atmosphere. When the watch is held nigh to the ear, the atmosphere is the conductor; when the watch is connected with the ear by the intervention of a rod of wood, or the solid parts of the head, these are the conductors. Now the apparatus of hearing of the fish presents conductors of the latter kind; water, a denser body than air, is the conducting medium; and the solid mass of the head, and, in fact, of the entire body, complete the conduction to the vital apparatus. Hence, in fishes, an humble contrivance is capable of effecting the same end as the higher-toned instruments of terrestrial animals. As fishes thus evidently possess the organ of hearing in a moderate degree of perfection, they must therefore hear with moderate acuteness, particularly such sounds as occasion a vibration of the element in which they reside; for example, an approcahing footstep; while the sounds which proceed from musical instruments, being less easily conveyed, are probably unknown to them : certainly this is the case with regard to toue." We constantly hear of fish coming to be fed at the sound of the bell. They rather come to the sound of the bell-ringer's feet, that is to the vibration caused by his foot-fall, and so indicating his presence.-ED. 
shall yield finer wool than they did that year before they came to feed in it, and coarser again if they shall return to their former pasture; and again return to a finer wool, being fed in the fine-wool ground. Which I tell you, that you may the better believe that I am certain, if I eatch a trout in one meadow he shall be white and faint, and very like to be lousy; and as certainly, if I catch a trout in the next meadow, he shall be strong, and red, and lusty, and much better meat. Trust me, scholar, I have caught many a trout in a particular meadow, that the very shape and the enamelled colour of him hath been such, as have joyed me to look on him: and I have then with much pleasure concluded with Solomon, "Everything is beautiful in his season."

I should by promise speak next of the salmon; but I will by your favour say a little of the umber or grayling, which is so like a trout for his shape and feeding, that I desire I may exercise your patience with a short discourse of him, and then the next shall be of the salmon.

[REMaRKs, ETc., TOUCHING THE TROUT.-Walton has dedicated portions of the Third and Fourth Day's fishing and dialogue, embracing: two very long chapters, to that interesting fish the Trout. To be sure the chapters are interspersed with songs, conviviality, and conversation on many subjects besides fish. This good father of us anglers knew well how to catch a trout with a worm, or with a live May-fly; but certainly he was not an adept at taking that fish with the artificial fly or by spinning the minnow. Nor do I at all think that his knowledge of the natural history of the trout, of its habits, and of the methods of breeding it, was either accurate or profound.

I shall begin with the natural history of the fish, and most probably state that which will appear heterodox to thousands. We know the history of salmon, but certainly not of trout, because there are so many varieties of that fish differing in appearance, size, colour, shape, and habits. As Walton and Cotton treat only of the common trout, perhaps I ought to have confined myself to that fish, and avoided the other species. My love for the art I have so long possessed prevents me. To begin :-

The common trout is the salmo fario of Linnæus. On its lateral line it has red spots, its tail is much forked when out of condition, and hardly forked at all when the fish is in full season, at the end of June. It is yellowish about the belly, darkish on the back, and in the upper part of the sides has deep purple and pink spots. The head of the female is blunter than that of the male, which, if he is an old fish, has the lower jaw more elongated than the upper. The rays of the dorsal fin are thirteen, pectoral thirteen, ventral nine, anal nine, and caudal or tail twenty-five. Guided by this description, no one can fail to recognise the trout. Let me utter one caution. He is not always of the colour 
described, and the best signalement must be sought for in the rays of his fins. I have seen trout of the very same species, nay, probably, of the same brood, differing much in colour; some dark, some bright, and some yellow. Colour depends on depth of water. In deep and shaded waters, yellow and dark-coloured trout will be found; in shallow waters, bright ones. The chemical properties of light are the cause. The sun's rays can penetrate and oxygenate the shallow exposed streams, and hence the brightness of the fish resident there. Light is wanting in the deep and shaded rvaters, and hence the darkness in the colour of its denizens. The general habits of the common trout are well enough known. Its food are worms, small fish, larvæ, grubs, caterpillars, flies, etc. On flies it thrives best, next on fish, and worst of all on worms. Very large fish thrive best on fish-food. It breeds in September, October, and November, rarely earlier, but sometimes later. What is called the "throng" breeding season depends upon temperature-upon season and locality. 'The trout of England breed earlier' than those of the North of Scotland. They breed in the shallows at the heads of rivers, and in the smallest rivulets. Male and female assist each other in excavating in the sand and gravel a bed, or nest for their spawn. The female first deposits her ova, or eggs, and then the male sheds his milt over them, and to impregnates them. The fish then covers over with sand and gravel the deposited and impregnated ova. In about fifty days, on an average, they are hatched, but perfect incubation may, in a cold climate, or in a very severe winter, require thirty days longer. The growth of trout is not precisely ascertained. It is not possible to do so. They differ so much in size, though of the same species, in different rivers, that it is extremely difficult to strike an average. Guessing, I should say that the common river trout averages about one pound in two years. I think (many will think me mad for doing so) that the sea-trout, the bulltrout, and many other varieties, are crosses of ancient date between the common trout and the pure salmon. I think also, that these crosses inter-generate, if I may use the word, and hence a vast variety of rivertrout. Of lake-trout, bred in lakes not connected with salmon rivers, I have little to say. Every such lake has its particular trout; some small, some large, some handsome, some ugly, some well-flavoured, some ill-flavoured, all which conditions are the results of the volume and depth of water, its temperature, and the quantity and quality of the food it affords. It is only in very large lakes that the immense grey laketrout, or salmoferox, is found. In my remarks on the salmon, at the end of the seventh chapter, I'll show how trout and that fish are bred artificially.

If I fished for trout with the worm, I should never use a float, but put a few shot on my line, increasing or diminishing the number according. to the strength or weakness of the current. I should have a swivel on the gut foot-line, about two feet from the hook, and I should fish close to the bottom, allowing the worm to move on with the current-more slowly. than the stream where it is rapid. Two middle-sized worms on the hook at the same time are better than one, and the best worms are brandlings and blue-heads. The most deadly way of fishing for trout is by 
spinning the minnow for moderately sized fish, and the gudgeon, dace, and even a small trout for large trout. A very large fish of that species, such as the great grey lake trout, will take a common trout, weighing half or three-quarters of a pound. A Thames trout, of the weight of twelve pounds, will take as a bait the largest gudgeon, or even a dace, four inches in length. It is a general rule, that large baits are the best for large fish; they will not trouble themselves about small ones. The best minnow-flight consists of eleven hooks [see cut at end of these remarks] : one lip hook, two treble hooks, a single hook to curb the fish bait, a little below the vent, a treble hook to pass "fly" or free beyond the tail. In the London fishing-tackle shops every sort of spinning tackle is sold, but I conscientiously believe the above "flight" is the best. It must be firmly tied on gut for small fish, on gimp for large ones. There must be a swivel close to the lip-hook, and another on the gut, or gimp-trace, two feet higher up. The trace should be shotted at about twelve inches from the lip-hook. The spinning rod need never to be more than twelve feet in length, and it should be rather stiff than pliant. Its rings should be large and stand upright. It should be made of the following woods, and be of four joints, butt, ash, or willow, second joint hickory, small piece ditto, and top lancewood and bamboo-cane. The line should be stout, and of platted silk, and it should be oiled or varnished. The winch should be large, and of free action. The tyro must cast the spinning-bait and work it through the water thus : uncoil from the winch as much line as is wanted, allowing the coils to rest at your feet. Let the bait hang not more than a yard from the top of the rod, then, poising and bringing back the rod either to the left or right, propel the bait somewhat upwards and forwards; and its weight, and the momentum given to it, will carry out all the coiled line. As soon as the bait falls in the water, commence drawing it towards you by short pulls of the line either with the right or left hand, making the bait spin straightly towards you with moderate speed. When the bait is drawn in close to the fisher, he must lift it out of the water, and repeat the cast. When there is what is called a "run," the angler must strike sharply, and play the hooked fish boldly. Repeat casting until the stream or pool is fished all over, and then move to another spot. All looks used in spinning should be made of hright wire. There is a spinning flight called Colonel Hawker's, sold in all the shops, which I consider very good; but it is not very easy to bait with it. Artificial minnows are to be bought, ready mounted, and they must be used just in the way I have described. Spinning answers best in water that has been recently discoloured by rain, and is useless in clear shallow water. The Thames punt-men are the best masters and teachers of the art of spinning in the world.-ED.]

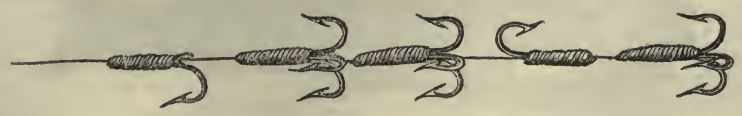




\section{CHAPTER VI.}

OBSERVATIONS ON THE UMBER OR GRAYLING, AND DIRECTIONS HOW TO FISH FOR HIM.

\section{[fourth 迎an.]}

PIsc. The umberand grayling are thought by some to differ, as the herring and pilchard do. But though they may do so in other nations, I think those in England differ in nothing but their names. Aldrovandus says they be of a trout kind; and Gesner says, that in his country, which is in Switzerland, he is accounted the choicest of all fish. And in Italy, he is in the month of May so highly valued, that he is sold at a much higher rate than any other fish. The French, which call the chub un vilain, call the umber of the lake Leman un umble chevalier: and they value the umber or grayling so highly, that they say he feeds on gold, and say that many have been caught out of their famous river Loire, out of whose bellies grains of gold have been often taken. And some think that he feeds on water-thyme, and smells of it at his first taking out of the water; and they may think so with as good reason as we do that our smelts smell like violets at their first being caught, which I think is a truth. 7 Aldrovandus says, the salmon, the grayling, and trout, and all fish that live in clear and sharp streams, are made by their mother nature of such exact shape and pleasant colours purposely to invite us to a joy and contentedness in feasting with her. Whether this is a truth or not it is not my purpose to dispute: but't is certain, all that write of the umber declare him to be very medicinable. And Gesner says, that the fat of an umber or GraxLING, being set, with a little honey, a day or two in the sun,

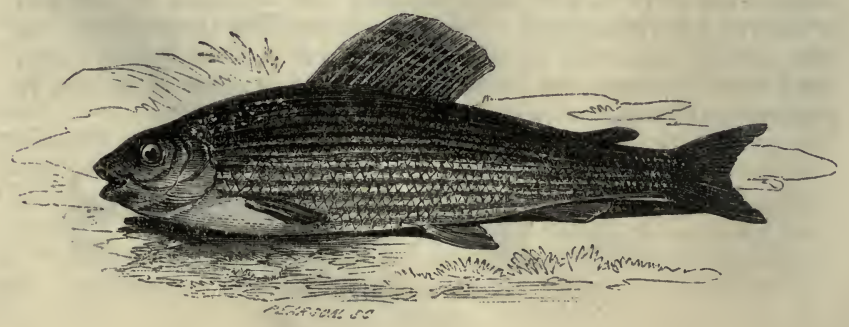


in a little glass, is very excellent against redness; or swarthiness, or anything that breeds in the eyes. Salvian takes him to be called umber from his swift swimming, or gliding out of sight more like a shadow or a ghost than a fish. Much more might be said both of his smell and taste : but I shall only tell you, that St. Ambrose, the glorious bishop of Milan, who lived when the church kept fasting days, calls him the flower-fish, or flower of fishes: and that he was so far in love with him that he would not let him pass without the honour of a long discourse ; but I must, and pass on to tell you how to take this dainty fish.

First, note, that he grows not to the bigness of a trout; for the biggest of them do not usually exceed eighteen inches. He lives in such rivers as the trout does, and is usually taken with the same baits as the trout is, and after the same manner; for he will bite both at the minnow, or worm, or fly; though he bites not often at the minnow, and is very gamesome at the fly, and much simpler, and therefore bolder than a trout; for he will rise twenty times at a fly, if you miss him, and yet rise again. He has been taken with a fly made of the red feathers of a parakita, a strange outlandish bird; and he will rise at a fly not unlike a gnat or a small moth, or indeed at most flies that are not too big. He is a fish that lurks close all winter, but is very pleasant and jolly after mid-April, and in May, and in the hot months : he is of a very fine shape, his flesh is white; his teeth, those little ones that he has, are in his throat, yet he has so tender a mouth, that he is oftener lost after an angler has hooked him, than any other fish. Though there be many of these fishes in the delicate river Dove and Trent, and some other small rivers, as that which runs by Salisbury, * yet he is not so general a fish as the trout, nor to me so good to eat or to angle for. And so I shall take my leave of him; and now come to some observations of the salmon, and how to catch him.

* Not one of these rivers is small. The Trent is a large navigable one. It now produces very few grayling. The Dove is the classic river of fly-fishers, rendered so by its abounding in trout and grayling, and by the extraordinary beauty of its scenery; and by the fact, that Charles Cotton, author of the second part of the "Complete Angler," resided on its banks, described it, and taught how grayling and trout are to be caught in it. In truth, Cotton's fly-fishing experience hardly went beyond the Dove and the neighbouring streams of Derbyshire. Such experience was amply sufficient, for he who could successfully fly-fish in the limpid waters of those rivers, need not hesitate to wet a fly anywhere. The Lathkil, a little brook of Derbyshire, is famous for its trout and no less so for the difficulty of catching them with a fly.-ED. 
[Remarks todching the Grayltig.-In my opinion this is one of the most gracefully shaped of our river ish. The trout is handsomer, but the grayling is prettier. The former is of Herculean beauty; the latter possesses that of Apollo, delieate, light, gracefully active. The trout is rather of golden hue, studded with bright pink ornaments ; the grayling is spangled with silver and purple. "It is a favourite fish of mine," I say (in a Handbook of Angling) - "takes a fly boldly, but does not show much resisting courage after having taken it and been hooked: it is a gamesome fish but not a game one. The grayling very rarely exceeds three pounds in weight, and a far greater number are caught under twelve ounces weight than above it. They are not like the trout, indigenous to this country; and very probably, on account of their being in season in the winter, when trout are not, and being an excellent gastronomic substitute for that fish; they were brought from the continent to this country by the monks, that those Sybarites might not be without a fresh water delicacy during the most festive period of the year." It has been remarked, in pronf of this, that they are found in rivers on whose banks monasteries and convents once abounded. The rule is exceedingly exceptional, for the fish is not found in any of the rivers of Ireland and Scotland, and in very few of those of England. Though monasteries once flourished in great numbers on the banks and lakes of Scotland and Ireland, still grayling have never been found in those waters. The truth is, as Mr. Blaine remarks, "grayling require other peculiarities of location besides those of temperature, such as a general character of the water they inhabit, and certain circumstances in the nature of its composition derived from its sources: with one or two exceptions, they are only found in rivers which belong to the southern and western parts of our island. It is probably owing to the abstraction of some of these requisites, that the multiplication of these fish in several rivers where they have been attempted to be naturalized has not been attended with suecess. (I recollect Mr. Warburton, formerly member for Bridport, attempting to introduce grayling into the upper parts of the Thames. Though he carried a large number of store fish of that species to be placed in the river, they never bred, and have long since totally disappeared.) In some they soon disappeared; in others, they remained, but never thrived; while in some waters, though they lived and at first increased, yet they were afterwards observed to shift their quarters to different parts of the same river, in most of which cases it proved, as in that which occurred in the Test in Hampshire, that they migrated from above downwards, probably in search of deep and tranquil waters; for the angler cannot fail to observe that grayling do not, like trout, affect very rapid shallows, and the boldest torrents : on the contrary, they seem to thrive best where milder currents alternate with deep and extensive pools; neither do they do well where strong gravel or pure rock characterise the bottoms; for it appears necessary to them, that the ground over which they swim, should be compounded of sand, gravel, and loam ; which mixture is, as we know, very favourable to the production of the insect food on which they principally subsist." I have frequently found small grayling on rapid shallows, but never large ones, 
except in the spawning season. The haunts of large grayling are the somewhat deep and slowly running tails of streams or pools, a few yards before the formation of the rapid heads of other pools.

The grayling is scientifically termed salmo thymallus, from a general belief that it emits a smell similar to that of thyme. In my opinion, as well as in that of others, it faintly smells of cucumber. Dr. Fleming (Brit. Animal.) calls this fish the grey salmon, and describes it as having longitudinal dusky blue lines (some consider them grey, and hence its name "gray-lines" abbreviated into "grayling") and violet-coloured dorsal fin barred with brown; length from ten to eighteen inches; head obtuse, and the upper jaw longest. The rays of its dorsal fin are eighteen, pectoral twelve, ventral eleven, and caudal nineteen. Its dorsal fin is remarkably large, enabling it to rise to the surface of the water and sink again with very great rapidity. It never jumps out of the water like the trout; and is incapable of surmounting either natural or artificial obstructions in the water, such as cascades or weirs. By striking its immense dorsal fin downwards against the water, it raises itself rapidly to the surface, and by striking the same fin upwards against the superincumbent element, it causes itself to descend with stone-like velocity. The grayling rivers are the Dove, Teme, Lug, Test (these are the best rivers), Wye, both in Herefordshire and Derbyshire, Severn, Trent, Irvon, Hidder, Wharf and Avon in Hampshire. Mr. Henry George, of Worcester, says of the Teme, that it produces the finest grayling in England. He states, "a Teme grayling, in the height of condition, in October or November, when first taken out of the water, is one of the handsomest and most symmetrical fish that rise at the fly in our beautiful streams; and if laid upon the hand, and looked at horizontally, presents the most beautiful purple or violet hue from snout to tail. The snout is sharp, and the eyes lozenge-shaped; this fish is hog-backed, and the back is of a dark purple colour, with small dark square spots on the sides. The under part of the lower jaw and belly touch the ground together; the latter is brilliantly white, with a narrow ledge or lacing of gold, extending along each side, from the pectoral towards the ventral fin; and the tail, and pectoral and ventral fins are of a beautiful purple. The dorsal fin is very large, and a beautiful picture, covered with scarlet waves and spots intermingled with purple. The little velvet [adipose] fin on the back near the tail, is also dark purple, and the fish smells like a cucumber."

The grayling is a native of the north-eastern rivers of France, of Switzerland, Bavaria, the Tyrol, the northern rivers of Italy, and of many of the smaller rivers of the German states. It spawns in April and early in May, and is in season in July, but not fully so until September. The finest grayling are caught in the winter and early spring months. In the winter months, in clear frosty weather, when the water is low, they will take small dark dun fiies from eleven to two o'clock, particularly if the sun be gently shining. . In deep water at this season they will take gentles. In the autumn months they will take small artificial ant-flies, small brown and furnace hackles, the soldier palmer, and the coch-y-bondhu; also wasp-grubs, and the green grubs that are 
found on cabbage-leaves. The artificial grasshopper is an excellent bait for them : it must be sunk to the bottom and drawn up and down continually. When gentles or grubs are used, the sinking and drawing system must be resorted to. Sir Humphry Davy (vide Salmonia) understood grayling fishing well, and practised it with great ardour in this country and in Germany. I will quote some of his remarks on the subject: "The grayling lies deeper, and is not so shy a fish as the trout; and, provided your link [gut casting line] is fine, is not apt to be scared by the cast of flies on the water, The fineness of the link, and of the gut to which your flies are attached, is a most essential point, and the clearer the stream the finer should be the tackle. I have known good fishermen foiled by using gut of ordinary thickness, though their flies were of the right size and colour. Very slender transparent gut, of the colour of the water, is one of the most important causes of success in grayling fishing. He is to be fished for at all times, for he is rarely so much out of season as to be a bad fish; and when there are flies on the water he will generally take them : but as the trout may be considered as a spring and summer fish, so the grayling may be considered as a winter and autumnal fish. Grayling do not refuse large flies. [In March and April I use these flies, the March-brown, the oak-fly, the silver palmer, and honey dun-fly, the sand and cow-dung-fly dressed on No. 9 hooks]; and in the Avon and Test in Hampshire, May-flies and even moths, are greedily taken in the summer by large grayling. There is no method more killing for large grayling than applying a grasshopper to the point of a leaded hook, the lead and shank of which are covered with green and yellow silk, to imitate the body of the insect : this mode of fishing is called sinking and drawing. I have seen it practised in this river with as much success as maggot fishing, and the fish taken were all of the largest size; the method being most successful in deep holes, where the bottom was not visible, which are the natural haunts of such fish. In the winter grayling rise for an hour or two in bright and tolerably warm weather; and at this time, the smallest imitations of black or pale gnats that can be made, on the smallest sized hook, succeed best in taking them. In July, imitations of the black and red palmer worms, which I believe are taken for black or brown or red beetles or cockchafers, kill well; and in dark weather there are usually very light duns near the water. In August, imitations of the house fly and bluebottle, and the red and black ant-fly, are taken, and are particularly killing after fioods in autumn, when great quantities of the fly are destroyed and washed down the river. In this month, on cloudy days, pale blue duns often appear, and they are still more common in September. Throughout the summer and autumn, in fine calm evenings, a large dun fly with a pale yellow body, is greedily taken by grayling after sunset, and the imitation of it is very killing. In the end of October, and through November, there is no fly-fishing but in the middle of the day, when imitations of the smaller duns may be used with great success; and I have often seen the fish sport most, and fly-fishing pursued with great success in bright sunshine, from twelve till half-past two o'clock, after severe frosts in the morning; and I even caught, under these circum- 
stances, a very fine dish of fish on the 7th November, 1816." The winter of 1838 was a very severe one: in February of that year, with snow upon the ground, but with the weather frosty and clear, and the water low and bright, I eaught grayling in the Dove with very small dun hackles. The best summer fly for grayling, on dark days, and morning and evenings, is the fern-fly (described in note to p. 91), which $I$ have used in the Dove with very great success. In a list of flies to be given hereafter in chapters vii. and viii. of part ii. of this work, I shall point out some eagerly taken by grayling.-ED.]

\section{CHAPTER VII.}

OBSERVATIONS ON THE SALMON ; WITH DIRECTIONS HOW TO FISH FOR HIM.

\section{[ffourth 政an.]}

Pisc. The salmon is accounted the king of fresh-water fish; and is ever bred in rivers relating to the sea, yet so high or far from it, as admits of no tincture of salt or brackishness. He is said to breed, or cast his spawn, in most rivers, in the month of August: some say, that then they dig a hole or grave in a safe place in the gravel, and there place their eggs or spawn, after the melter has done his natural office, and then hide it most cunningly, and cover it over with gravel and stones, ${ }^{*}$ and then leave it to that Creator's protection, who, by a gentle heat which He infuses into that cold element, makes it brood and beget life in the spawn, and to become samlets early in the spring next following:t

The salmons having spent their appointed time, and done

* See observations at the end of the chapter on the formation of the salmonbed.-ED.

$\dagger$ If salmon spawned in August, which not one in many thousand does, there would be young salmon (salmon-fry) in December, nay in November. Salmon ova are incubated in about 120 days on the average-in the winter months in 140 days; in those of autumn and winter in about 100 days. The duration of the incubating time depends on the temperature of atmosphere and water. Salmon spawn deposited and impregnated on the 1st of August, would be hatched very probably by the 1st of November, whereas spawn deposited in November would not be incubated before March. The temperature at the two periods would make the difference. I entreat the reader to study carefully the remarks on the natural history and habits of the salmon, which $I$ shall append to this chapter.-ED. 
this natural duty in the fresh waters, they then haste to the sea before winter, both the melter and spawner : but if they be stopped by flood-gates or weirs or lost in the fresh waters, then those so left behind by degrees grow sick, and lean, and unseasonable, and kipper ; that is to say, have bony gristles grow out of their lower chaps, not unlike a hawk's beak, which hinders their feeding; and in time, such fish, so left behind, pine away and die. It is observed, that he may live thus one year from the sea; but he then grows insipid and tasteless, and loses both his blood and strength, and pines and dies the second year. And it is noted, that those little salmons called skeggers, which abound in many rivers relating to the sea, are bred by such sick salmons that might not go to the sea; and that though they abound, yet they never thrive to any considerable bigness.

But if the old salmon gets to the sea, then that gristle, which shows him to be kipper, wears away, or is cast off, as the eagle is said to cast his bill ; and he recovers his strength, and comes next summer to the same river, if it be possible, to enjoy the former pleasures that there possessed him ; for, as one has wittily observed, he has, like some persons of honour and riches, which have both their winter and summer houses, the fresh rivers for summer, and the salt water for winter, to spend his life in; which is not, as Sir Francis Bacon hath observed in his "History of Life and Death," above ten years. And it is to be observed, that though the salmon does grow big in the sea, yet he grows not fat but in fresh rivers; and it is observed, that the farther they get from the sea, they be both the fatter and better.*

* This paragraph, with the one that precedes it, teems with palpable ignorance. Salmon, having spawned, proceed to sea immediately they have recovered from the exhaustion consequent on spawning. It is, therefore, in the spring, before summer, and not as Walton says, "before winter," that they generally migrate sea-ward. Their remaining for a year, under any circumstances, in fresh water, after they have become adult, never occurs. The gristle, or crook-shaped excrescence, is only found in male salmon, generally about spawning time, and some weeks afterwards, and disappears as the fish gets into condition, to re-appear again the following breeding season. The use of this excrescence is not accurately known. Skeggers are smolts, the one-year-old produce of healthy, and not of " sick salmons." Salmon cannot be called sick, except between the periods of spawning and going to sea. They are then called "kelts," and not " kippers." A "kipper" now means a salmon cured by salt, sugar, and drying. It is in the sea, and not in fresh water, that salmon grow "big and fat." After the first year, they do not increase in size in fresh water, but, on the contrary, diminish in bulk. When we say a "clear freshrun" salmon, we mean one in good condition, bright and fat, and caught just 
Next I shall tell you, that though they make very hard shift to get out of the fresh rivers into the sea, yet they will make a harder shift to get out of the salt into the fresh rivers, to spawn, or possess the pleasures that they have formerly found in them : to which end they will force themselves through flood-gates, or over weirs or hedges, or stops in the water, even to a height beyond common belief. Gesner speaks of such plices as are known to be above eight feet high above water. And our Camden mentions, in his "Britannia," the like wonder to be in Pembrokeshire, where the river Tivy falls into the sea ; and that the fall is so downright, and so high, that the people stand and wonder at the strength and sleight by which they see the salmon use to get out of the sea into the said river; and the manner and height of the place is so notable, that it is known, far, by the name of the "Salmon-leap." Concerning which, take this also out of Michael Drayton,* my honest old friend, as he tells it you, in his "Polyolbion :"

And when the salmon seeks a fresher stream to find, Which hither from the sea comes yearly by his kind; As he tow'rds season grows, and stems the wat'ry tract Where Tivy falling down, makes a high cataract, Forced by the rising rocks that there her course oppose, As though within her bounds they meant her to inclose ; Here, when the labouring fish does at the foot arrive, And finds that by his strength he does but vainly strive, His tail takes in his mouth, $\uparrow$ and, bending like a bow, That's to full compass drawn, aloft himself doth throw ;

on its return from the sea to its native river. In a few days afterwards, it is no longer clear and fresh-run, and in two or three weeks loses its fat or curd, becomes comparatively lean, and almost black on the head, gill-covers and back. This is the result of its sojourn in fresh water, in which it no longer finds that food on which it thrived in its salt-water feeding-grounds.-ED.

* An excellent poet, born in Warwickshire, 1563. Among his works is the "Polyolbion," a chorographical description of the rivers, mountains, forests, castles, etc., in this island. . Though this poem has great merit, it is rendered much more valuable by the learned notes of Mr. Selden. The author died in 1631 , and lies buried among the poets in Westminster Abbey.-H.

+ This error prevails to the present day. The salmon never curves itself, or puts its tail in its mouth for the purpose of jumping from the water. It is by means of its fins, as explained in the observations at the end of this chapter, that it throws itself from the water. It cannot jump perpendicularly to the height of eight feet, but may, probably, if there be sufficient depth of water, jump six fect. In shallow water not half that distance. Its spring to surmount cascades or weirs is not perpendicular-not an upright standing leap-but, as it were, a running jump forwards, gradually attaining, in extreme instances; a height of six feet. In subsequent remarks, the saltatory progress of the salmon is explained from actual observation.-ED. 
Then springing at his height, as doth a little wand

That, bended end to end, and started from man's hand,

Far oft itself doth cast; so does the salmon vault :

And if at first he fail, his second summersault

He instantly essays; and from his nimble ring,

Still yerking, never leaves until himself he fling

Above the opposing stream

This Michael Drayton tells you of this leap or summersault of the salmon.

And next I shall tell you, that it is observed by Geswer and others, that there is no better salmon than in England; and that though some of our northern counties have as fat and as large as the river Thames, yet none are of so excellent a taste.*

And as I have told you that Sir Francis Bacon observes, the age of a salmon exceeds not ten years; so let me next tell you, that his growth is yery sudden : it is said, that after he is got into the sea, he becomes from a samlet not so big as a gudgeon, to be a salmon, in as short a time as a gosling becomes to be a goose. Much of this has been observed by tying a ribbon, or some known tape or thread, in the tail of some young salmons, which have been taken in weirs as they have swimmed towards the salt water, and then by talking a part of them again with the known mark at the same place at their return from the sea, which is usually about six months after $; \dagger$ and the like experiment hath been tried upon

* Salmon have long since disappeared from the Thames. Those formerly caught in it, the very old Thames fishermen tell us, were of such fine flavour as to fetch from six shillings to ten shillings a pound. We fancy that the price was enhanced by the rarity and freshness of the fish. If Scotch or Irish Salmon could be brought into the London market on the day they were captured, their flavour would equal those of Thames or Severn salmon. The great mass of salmon brought to Billingsgate are a week out of the water. Ice keeps them still fresh, but their curd and high flavour are gone. It is difficult to decide which countries or rivers produce the best salmon : some prefer Dutch, others Scotch or Irish salmon. They judge of it as it appears in the London market. In our opinion, Irish salmon would turn out the best, if it were as carefully packed and forwarded to London as the salmon from other countries. The few salmon that come from the Tyne, Severn, and Hampshire, reach London soon after they are captured; and their condition, not having been deteriorated by several days keeping in ice, their silvery coat and bright deep vermilion-coloured flesh, attract the connoisseur, and secure the best prices. In our opinion, there are several small-sized salmon-rivers in Ireland and Scotland, from which, on account of the small number captured, or the expense of carriage, no salmon are sent to London, that produce fish of the finest quality.-ED.

+ On an average, salmon return from sea to their native rivers in three months, rarely in a month, but very frequently in two. A sea-sojourn of four months is rare; one of six quite abnormal.-ED. 
young swallows, who have, after six months' absence, been observed to return to the same chimney, there to make their nests and habitations for the summer following: which has inclined many to think, that every salmon usually* returns to the same river in which it was bred, as young pigeons taken out of the same dove-cote have also been observed to do.

And you are yet to observe farther, that the he-salmon is usually bigger than the spawner; and that he is more kipper, and less able to endure a winter in the fresh water than she is : yet she is, at that time of looking less kipper and better; as watery, and as bad meat. $\uparrow$

And yet you are to observe, that as there is no general rule without an exception, so there are some few rivers in this nation that have trouts and salmons in season in winter, as it is certain there be in the river Wye, in Monmouthshire, where they be in season, as Camden observes, from September till April. $\$$ But, my scholar, the observation of this and many other things, I must in manners omit, because they will prove too large for our narrow compass of time, and therefore I shall next fall upon my directions how to fish for this salmon.

And for that, first you shall observe; that usually he stays not long in a place, as trouts will, but, as I said, covets still to go nearer the spring head; and that he does not, as the trout and many other fish, lie near the water-side, or bank, or roots of trees, but swims in the deep and broad parts of the water, $\oint$ and usually in the middle, and near the ground, and

* Not only " usually," but always, if not disabled or killed.-ED.

+ This short paragraph is sadly erroneous. A female salmon may be twice as large, or twice as small, as the male with which she consorts on the spawning bed. She is frequently obliged to mate with male fish of all sizes and ages, nay, with small male trout. If a male and female salmon, the produce of the same brood, were to consort, after having been the same time on the same feeding-ground at sea, the female would be the larger fish. She suffers more from the effects of spawning than the male, and he is better, not "less, able to endure a winter in the fresh water than she is." He more promptly recovers from the " kelt" state, and is sooner fitted for his sea voyage.-ED.

₹. I do not think there are any rivers in the empire which have the common, non-migratory trout "in season in winter." But there are a few rivers, the majority of which are Welch, in which salmon are in season, or at least clean and fresh-run in winter-in Novernber and December. These fish are late spawners. Very early spawners may be taken, in very small numbers in January, in what are considered the "early" salmon rivers of Ireland and Scotland.-ED.

\$ The salmon, in coming up the estuaries, seldom swims in the middle, but by the sides, and for that reason he is caught in the stake-nets that project, some hundred yards, or more, into the tidal waters. In rivers his haunts are 
that there you are to fish for him, and that he is to be caught. as the trout is, with a worm, a minnow, which some call a penk, or with a fly.

And you are to observe, that he is very seldom observed to bite at a minnow, yet sometimes he will, and not usually at a fly; but more usually at a worm, and then most usually at a lob or garden-worm, which should be well scoured, that is to say, kept seven or eight days in moss before you fish with them : and if you double your time of eight into sixteen, twenty, or more days, it is still the better; for the worms will still be clearer, tougher, and more lively, and continue so longer upon your hook; and they may be kept longer by keeping them cool and in fresh moss, and some advise to put camphor into it.

Note also, that many used to fish for a salmon with a ring of wire on the top of their rod, through which the line may run to as great a length as is needful when he is hooked. And to that end, some use a wheel about the middle of their rod, or near their hand; which is to be observed better by seeing one of them, than by a large demonstration of words.

And now I shall tell you that which may be called a secret : I have been a-fishing with old Oliver Henley, now with God, a noted fisher both for trout and salmon, and have observed, that he would usually take three or four worms out

various; sometimes cloze by the banks, in an eddy or little current, formed by rocks or roots; sometimes a little further out; sometimes in the middle, or at the sides, of the rapidly running tails of pools; sometimes at their head; sometimes in the middle of deep or shallow currents. In fine, in any spot to which the current or the chicf strength of it, tends or diverges, thereby bringing some sort of food to the salmon on the look out for it. Two rocks, a yard or two apart, will form an angular current, or a wedge-like one. At the point of the wedge, no matter whether in the middle of the river, or by its sides, salmon surely lie, because to that point insects, larvæ, worms, and other food are washed, sucked in at the head of the triangular rapid formed by the two rocks. If a sharp-run is caused by a rock placed at a short distance from the bank, the salmon will lie close by the inside of the rock, or near the bank, or at the tail of the sharp-run. The precise lairs of salnıon in different rivers, can only be known by experience. No general rule respecting them will hold good. On first fishing a river, you must have a guide-a fisherman, born, as it were, on its banks-and he will show you what are called the best "salmon-casts." Without such a guide, you will waste much time, by fishing likely-looking spots, but which, from some cause or other unknown to you, are not frequented by salmon; and you will pass over, without fishing them, unfavourable spots apparently, but where salmon lie, from some cause also unknown to you. In the pools immediately above waterfalls, or any difficult "salmon-leap," salmon very rarely take the fly, or any other bait. They stop in these pools for the sake of repose, and are disinclined to disturb it even for the sake of food. To the non-local salmon-fisher a local guide is indispensable.-ED. 
of his bag, and put them into a little box in his pocket, where he would usually let them continue half an hour or more, before he would bait his hook with them. I have asked him his reason, and he has replied: "He did but pick the best out to be in readiness against he baited his hook the next time :" but he has been observed, both by others and myself, to catch more fish than I or any other body that has ever gone a-fishing with him could do, and especially salmons; and I have been told lately by one of his most intimate and secret friends, that the box in which he put those worms, was anointed with a drop, or two or three, of the oil of ivyberries, made by expression or infusion; and told, that by the worms remaining in that box an hour, or a like time, they had incorporated a kind of smell that was irresistibly attractive, enough to force any fish within the smell of them, to bite. This I heard not long since from a friend, but have not tried it; yet I grant it probable, and refer my reader to Sir Francis Bacon's "Natural History," where he proves fishes may hear, and doubtless can more probably smell : and I am certain Gesner says the otter can smell in the water, and 1. know not but that fish may do so too; it is left for a lover of angling, or any that desires to improve that art, to try this conclusion.*

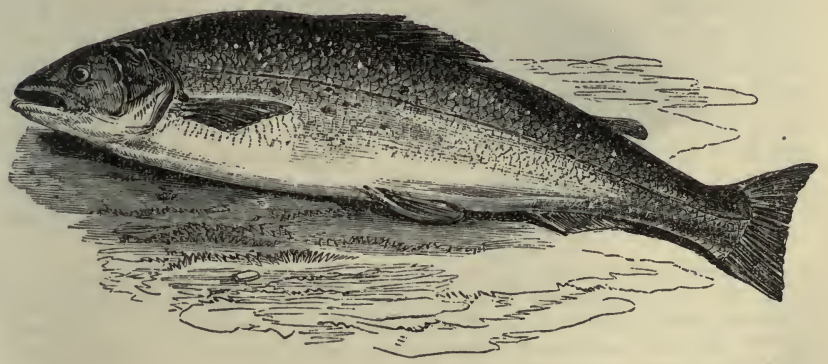

I shall also impart two other experiments (but not tried by myself), which I will deliver in the same words that they

* By the word "conclusion," Walton means "experiment." He was too practical a bottom-fisher to have faith in scented baits. Respecting them, he only writes what he had heard from others. Although many old angling authors recommend perfumed baits, the use of them is lidiculed and exploded by modern artists. Very justly in our opinion.-ED. 
were given me, by an excellent angler, and a very friend, in writing: he told me the latter was too good to be told, but in a learned language, lest it should be made common.

"Take the stinking oil drawn out of the polybody of the oak by a retort, mixed with turpentine and hive-honey, and anoint your bait therewith, and it will doubtless draw the fish to it."

The other is this: "Vulnerc hederce grandissimce inflicta sudant balsanum oleo gelato, albicantique persimile, odoris vero longè suavissimi."

It is supremely sweet to any fish, and yet assafotida may do the like.

But in these things I have no great faith, yet grant it probable, and have had from some chemical men, namely, from Sir George Hastings and others, an affirmation of them to be very advantageous; but no more of these, especially not in this place.

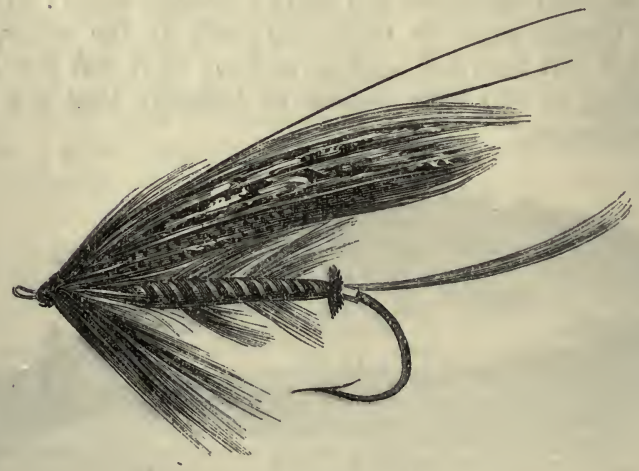

THE BALMON FLY,

I might here, before I take my leave of the salmon, tell you, that there is more than one sort of them; as, namely, a tecon, and another called in some places a samlet, or by some a skegger : but these and others, which $I$ forbear to name, may be fish of another kind, and differ as we know a herring and a pilchard do, which, I think, are as different as the rivers in which they breed, and must by me be left to the 
disquisitions of men of more leisure, and of greater abilities, than I profess myself to have.*

And lastly, I am to borrow so much of your promised patience as to tell you, that the trout or salmon, being in season, have, at their first taking out of the water, which continues during life, their bodies adorned, the one with such red spots, and the other with such black or blackish spots, as give them such an addition of natural beauty, as I think was never given to any woman by the artificial paint or patches in which they so much pride themselves in this age. And so I shall leave them both, and proceed to some observations on the pike.

[Remaris on the Natural History, Habits, artifictal BREEDING OF, AND FISHING FOR, SALMON.-It is not at all surprising that the venerable and venerated father of our art should have been but imperfectly acquainted with the history and the habits of the salmo salar, the progenitor of nearly every variety of salmonida (descendants of the salmon), chiefly by means of fortuitous alliances with the salmo fario, or pure river trout-it is not, I say, surprising, since even at the present day, not one in many thousand consumers of salmon, and not one in many hundred captors of it are acquainted with the extraordinary phases in the life of this valuable and splendid fish. Of its general habits I think I am accurately cognisant, although my opinions are disputed by many clever people, but I am happy to know that all careful observers agree with me. I shall give a rapid résumé of all I know of the fluvial monarch of the British Isles. The salmon-salmo salar-is called by Shaw the "silvery grey spotted salmon," with the jaws of the male fish incurvated; by Linnæus it is described with " rostro ultra inferiorem maxillam prominente" (snout projecting beyond the lower jaws), and by Dr. Fleming it is described with upper jaw longest, teeth on the lower; dorsal fin fourteen rays, pectoral fourteen, ventral ten, anal thirteen, and caudal (or tail) twenty-one rays. The salmon is a freshwater fish, for in fresh-water it breeds, passes the whole of the first year

* There is a fish in many rivers, of the salmon kind, which, though very small, is thought by some curious persons to be of the same species; and this, I take it, is the fish known by the different names of salmon-pink, shedders, skeggers, and last-springs. But there is another small fish, very much resem. bling these in shape and colour, called the gravel-last-spring, found only in the river Wye and Severn; which is, undoubtedly, a distinct species. These spawn about the beginning of September: and in the Wye $I$ have taken them with an ant-fly as fast as I could throw. Perhaps this is what Walton calls the tecon.-H.

[NorE.-All the fish named, except the gravel-last-spring, are salmon-fry of different ages, from three or four months to twelve. The gravel-last-spring is, in all probability, the little trout called a "parr." It is found in many rivers besides the Wye and Severn. Walton's "tecon" may be the parr. Samlet, skegger, etc., are local names for young salmon, before their first migration to sea.-ED.] 
of its existence in it, and two-thirds, at least, of its after-life, or eight months out of every twelve. It migrates to sea annually, making its first voyage at the age of twelve months or thereabouts, never before, but sometimes a little later, and repeating it every year, and in some rare instances, twice a-year, as long as it lives. It invariably returns-life permitting-to breed in the rivers in which it has been bred. Take a salmon bred in the Shin, in Sutherlandshire, and set it at liberty in the Tweed, at Berwick, and it will not ascend the Tweed, but will, if not slain in transitu, return to its native river, the Shin, traversing hundreds of miles of ocean to do so. Is this wonderful? Not more wonderful than,-

"The swallow twittering from its straw-built shed,"

migrating, on the first appearance of winter on these shores, to the warm atmosphere, yielding insect food, of Africa, and returning to its natal locality in the spring, to live and give life in the temperate summer of a temperate zone. The annual emigrations of fish and fowl are caused by natural wants, but the instinct, "true as the needle to the pole," that guides them, undeviatingly, in their long out and return voyages, through the stormy air and through the tempest-tossed seas, is wonderful unto adoration of the Providence that hath implanted it in these animals of its creation. I will here give a happy illustration of the invariable habit of salmon returning to the rivers in which they first saw life. It is taken from my "Book of the Salmon," p. 172 :- "Loch-shin, a piece of water about 20 miles by 14 , situate in the heart of the Sutherlandshire mountains, is the immediate feeder of the river Shin, noted for the abundance of its salmon. The Loch itself has four feeders, middlingsized rivers, viz., the Terry, Fiack, Garvy, and Curvy, in which, previously to the year 1836, not a salmon was ever seen, though many were in the habit of entering the loch or lake. In the year mentioned, at the request of his Grace of Sutherland, and Mr. Loch, M.P., salmon were caught in the river Shin, shortly before the spawning season, and conveyed to the four rivers above named, amongst which they were distributed in due proportion. Mr. Andrew Young, the Duke's salmon-factor, and our best natural historian of salmon, was the managing director on the occasion. In the winter season all the fish spawned, each in the river into which it was put. Now, mark one of the consequences : salmon at present, and ever since, come regularly to spawn, traversing the lake, \&c., to do so, in all those heretofore salmonless rivers. Nay, more, the fish hatched in the Terry, at least those that survive long enough, return to the Terry; and the young of the other three rivers return from the sea to them, each grilse or salmon entering never-failingly the actual stream that gave it birth. What wonderful and unerring instinct! One might think that they would remain in the river Shin, and spawn where their first ancestors had spawned; but no, they leave their own natal shallows, pass down the lake, through the river Shin, along the Kyle of Sutherland, to the sea; and there having become adolescent, in three months or so, they retrace their route, and, after necessary rests on their long voyage, very frequently in the spots of 
their parents' nativity, they revisit, for the first time, but not for the last if they survive, the scenes of their birth and infancy. Revisit them -for what? Being nubile, to perform the nuptial rites, which they do where their forefathers begat them, and so they go on increasing and multiplying in colonies, heretofore tenantless of salmon, ever since volcanic action called from the 'vasty deep' the mountains and rivers of northern Caledonia!"”

Salmon never deposit their spawn in deep or still water. If they did, it would not be vivified. To vivify salmon ova impregnated by the milt, the combined influence of running water, and of atmospheric and solar action is necessary. Hence nature directs the salmon to spawn in shallows, or the fords as they are called, and even to run up narrow, shallow, rapid brooks, tributaries to the large salmon rivers, to do so. The female chooses a mate, who must make good her selection, by fighting for it, and in these salmon onslaughts the trite saying, "None but the brave deserve the fair," is fully verified. The male fish that remains in victorious possession of his aquatic bride proceeds with her to make choice of the marital bed, having driven from it all intruders. This bed is placed in a shallow part of the river, and consists of gravel and sand. Having chosen it, 'tis necessary to make it. I cannot tell whether it is the gentleman or lady that commences the operation first, which is done by one or the other darting its head into the gravel and burrowing upwards and downwards in it, the tail being used as a propelling power, and the snout as an excavating one. As soon as one fish gets tired the other takes its place. When one link or nest of the bed is deep and large enough the female enters it and deposits the mature portion of her ova, or part of it, and then retires. Forthwith the male takes her place and exudes some of his milt upon the ova, thereby impregnating them. This done, they proceed to dig another nest, the gravel and sand excavated from which cover the ova in the first nest made. This process is continued, nest above nest being dug, until the female has deposited all her ova. This is not the work of one day; it may extend from two or three to eight or ten according to the size and age of the fish, that is, according to the quantity of ova to be deposited. The younger and smaller the female fish the fewer ova she has, the sooner they will be all mature, and the more rapidly they will be deposited, and the whole process of digging the different nests of the narrow, longitudinal bed, and covering them in finished. Once covered in, the fish have no further care for the spawn. They drop down into the next deep pool and there remain until they become partly convalescent from the exhausting effects of spawning. Soon after this-they are now "kelts" or "spent" fish-they commence their voyage to the sea to recruit thoroughly their health, to grow and fatten in submarine feeding fields. In from 100 to 140 days (see note $\dagger$ to page 111) the ova are hatched. The foetus at first is like a large larva with a little sack of nutritious vitelline matter attached to its neck. On this it lives for about a month. When the sack disappears, the fotus assumes a fish shape, and is able to seek for food for itself amongst the gravel. At two months the fry is perfectly shaped, and 
strongly marked with transverse bars and pink spots along the lateral line. The transverse bars are erroneously called "parr" marks, some naturalists confounding the salmon fry with the diminutive trout called the "parr." At two months the fry eagerly feeds upon flies on the surface of the water, and small worms or larvæ at the bottom. It goes on slowly increasing in size until it is a year old, when the transverse bar-marks disappear, and it assumes a silvery exterior covering of small scales, called its "migratory" coat. It is now a smolt, and with the first moderate flood it takes its maiden trip to the sea. It feeds therein from two to four months on an average, and then immigrates to its natal river as a "grilse." In the ensuing autumn or winter it breeds for the first time, and returns again to the sea. Having sojourned there the requisite time, it immigrates for the second time and is now an adult, though not an aged salmon.

It would be impossible for me to write anything more correctly on the growth of salmon than that which $\mathrm{I}$ have already written in the "Book of the Salmon," p. 197 to 201, as follows:- "At the end of a year, the whole of it passed in fresh water, the young fish, on an average, weigh little more than three ounces. At that weight, being a smolt, it descends to the sea; and, if it should remain therein, say for eight or nine weeks, and then return to its natural element, fresh water, it will, in all probability, and no specific circumstances preventing, have increased by the end of that time, to the weight of five pounds or more. This rapidity of increase is most wonderful; and, though an adult salmon has been known to double its weight by sea-food in thirty-eight days, nothing like the increase that takes place between the smolt and grilse states ever after occurs. So, if the growth of salmon during the first year of its existence, is extremely slow in fresh water, it is, after that age, by far more than proportionately rapid in salt water. It will be well to bear in mind, that the growth of salmon is not always pro. portioned to the length of time they sojourn at sea. Several circumstances affect their rate of physical development. Amongst othersindeed they are the chief ones-quality and quantity of food found on the salt water feeding-grounds, and hereditary capacity for growth. By 'hereditary capacity,' I mean that the offspring of large fish have the inherent power of growing, and do grow, faster, and to a larger size than the young of salmon of small race. When I speak of large and small salmon, I refer to fish which eventually become very large, and to fish which, no matter what their age, will always be small,-in fact, to giant and dwarf breeds. The growth of salmon fry is pretty equal in all rivers; and, therefore, smolts, no matter whether they are the produce of large or small salmon, will be found in different rivers, not differing much in size. Such is not the case, however, after the smolt stage of existence. After that, the growth of the offspring of large-growing salmon is more rapid than that of the produce of salmon of more diminutive race. The smolts of rivers which produce salmon weighing forty pounds, grow faster to the grilse and in the salmon state, than the smolts of rivers whose largest fish do not exceed twenty pounds; and faster still than the smolts of rivers, the salmon of which 
do not average more than ten pounds in weight each. I will suppose three rivers running at short distances, the one from the other, into the same arm of the sea, as do the Shin, the Oikel, and the Carsely, and that smolts from each descend simultaneously, and take up their quarters on the same feeding-grounds. Again, I will suppose them entering, in the grilse state, simultaneously to their respective natal rivers. It will be found that the grilse of the Shin will be larger, and much longer than the grilse of the Oikel, and that the grilse of the Oikel will be larger than the grilse of the Carsely. The reason of this disparity is, the full-grown fish of the Shin are much larger than those of the Oikel, and the adult fish of the latter are somewhat larger than those of the Carsely. The growth of salmon at sea, and at sea only, for after having attained in fresh water the small size of smolts, they make no further increase in the non-saline element, depends on three things: duration of time they remain on their sea-feeding grounds, quality and quantity of food they obtain thereon, and hereditary capacity for growth, with apportioned powers of digestion. The grilse of small salmon, that is, of salmon which never grow beyond a small size, are handsomer, in every way better shaped, and generally of a brighter hue than the. grilse, the produce of larger-growing salmon. The grilse of the rivers Carron and Laxford, in Ross-shire and Sutherlandshire, are handsome, small-headed, thick and deep, and short in the body; the scales of which are small, smooth, and bright, because they are the offspring of small parent salmon; whereas, the grilse of the river Shin, in which salmon grow to a very large size, are ill-shapen fish, having large heads, long thin bodies, large, long fins, and large, rough, and by no means brilliant scales. It requires experience to distinguish a large and well-shaped grilse from a small salmon; indeed, grilse are sometimes larger than salmon, for the same reason that a young Dorking fowl is larger than an aged bantam. Frequently, the only distinguishing marks between grilse and salmon, are the smaller scales of the former, and the longer and larger fins in proportion to size. The fins of a grilse of eight pounds in weight, are longer and larger than those of a salmon of the same size. The tail of the grilse is deeply forked; that of the salmon less so, and very slightly indeed when in prime condition."

I have now stated the prominent habits of the salmon. Minor matters concerning it, I will narrate rapidly. First, of its powers of jumping from the water, and passing through it. The salmon throws itself straight, rising perpendicularly forward, from the water. Putting its tail in its mouth, and bounding like a skip-jack from the water, is an unaccountable nonsensical notion. Its body is quite straight when it makes its leap, and it does so, no doubt, chiefly by means of striking its fins against the body of water underneath it, and profiting by the resistance to the fins, it presses on them as if they were jumping spring. boards, and then darts forwards and upwards with great strength and agility. 'It rises, I should say, after a run or rush, and jumps in a slanting, uprising direction, like that of a man jumping over a gate. If the water be shallow, a salmon can only jump a very small height. It is only from deep water that a full bound can be made. The point 
d'appui for the fins can only be found in deep water, therefore in shallow water the leap is feeble and low. Six feet is the average distance in height a salmon can leap. I have read writers, who state that the salmon can swim at the rate of forty miles an hour. No; nor twenty, nor fifteen. Perhaps, at the top of its speed, it might do ten miles an hour, but only for a short "spurt" when passing through rapids, or when hooked by the angler. In still water, when the salmon is ascending rivers, its progress is very slow-a mere walking pace. It has been considered a singular fact, to find salmon with sea-lice adhering to it fifty miles up a river, but as these parasites stick to the fish for, at least, twenty-four hours after it has quitted salt water, the fact only proves an ascending progress of a small fraction more than two miles an hour. I have never hooked a fish that I could not keep up with at a sling trot. A fresh-run salmon, that is, a fish that has just entered the fresh water, is in its best condition, which it loses bit by bit every day it remains in the river. A fresh-run fish is fatter, and stronger, but its strength does not last, than a fish that has been in fresh water a fortnight or a month. The latter fish is, however, much more active, and more difficult to tire out. The reason is, that fresh water indurates its fins, diminishes obesity, and increases muscular endurance. A freshrun fish of large size makes a powerful rush or two, and then is, to use a racing phrase, "blown;" a fish not fresh-run will not make a tremendous rush at first on being hooked, but he will make a long-continued series of short, rapid runs, jump out of the water, and fight for his life longer, and with more "pluck," than the fat fresh-run salmon. In my opinion, it is more difficult to slay a ten-pound salmon that has been in fresh water a month, than it is to capture with rod and line an eighteen pounder just fresh and full-fed from the sea.

The subject is a curious one, and specially interesting to anglers. I will further explain it by an illustrative citation from my "Book of the Salmon," p. 201, et infra:- "Although a grilse or salmon, fresh run from the sea, is larger and in better condition than it will be after a few weeks' sojourn in fresh water, it is neither so strong nor so active-at all events, its strength and activity are not so enduring. One evident cause of this is, that fresh water hardens, and renders tough and stiffly elastic the fins, which are soft and feebly pliant in fish fresh from the sea ; and the natural consequence is, that, aided by those whalebone fin-rays (for to the consistency, or very nearly so, of that substance, fresh water reduces them), they are more capable of putting forth enduring effort, and strong and rapid motion, than the obese fresh-run fish, with its limber fins. A man rowing a heavy boat, with short pliant sculls, will make but slow progress through the water, and will be speedily fatigued; whereas, if he have long stout oars, they yield little to the water, and, by resistance but slightly elastic to it, the boat is propelled rapidly onwards, and the labour of the rower is considerably lightened. The pliant, almost powerless sculls of the rower, are the soft fins of the fresh-run fish-the stout oars, are the fins of the fish that has been a lengthy sojourner in fresh water: besides, fresh-run fish that have been recently feeding in rich sub-marine pastures, may not be unaptly compared to 
horses just taken up from luxurious grass or clover-fields, and submitted to dry feeding. The dry-feeding of salmon, are the insects, and larvæ, and small fish afforded to them in rivers. The consequence of dryfeeding on good food in moderate quantity, is the same with quadrupeds as with fish: they severally become less bulky, lose superfluous adipose matter, which is replaced by increase of muscular fibre, and therefore, though smaller in size, their strength and power of endurance are greater. This will explain why the angler finds it frequently more difficult to tire out a small fish than a larger one. For myself, I have had over and over again an easier task in capturing with rod and line a fresh-run salmon of fifteen pounds in weight, than a grilse half the size, which has been a few weeks training, as it were, in short, but strengthening commons in fresh water. At all times a grilse will be found more powerful than a salmon of the same weight, because the fins of grilse are larger in proportion to the size of their bodies, than the fins of adult salmon-grilse possess, consequently, easier and greater powers of locomotion than salmon. I cannot help fancying that the aldermanic salmon, when put to the speed by the spur of the hook, soon gets 'blown,' or, as a turfite wonld say, exhibits symptoms of ' distress,' whilst its child or brother, limited to spare, wholesome, freshwater diet, has its air-passages and muscular tissues unclogged by obesity; and, therefore, when compelled to make abnormal exertions, as it does when hooked by the fly-fisher, it evinees greater power of endurance, or 'bottom,' as it is termed."

Breeding fish artificially, is a nice but by no means difficult series of operations. Fish must be bred artificially in the same water from which the spawn is taken. The first operation consists of making the spawning bed. Build a stout wall about six feet or more, in a moderately deep and rapid stream, from the bank : the wall must be so high, as to dam off the highest floods, and its length must be regulated according to the number of beds you mean to make. If only one, a length of fifteen feet will do-if three, the wall must be fifty feet in length. There must be an iron and wired grating at the top and bottom of the wall, between them and the bank, to prevent the exit of the small salmon fry, and the entrance of small trout and other piscine pirates. The bed, that is, all the space between the wall and the bank, must consist of gravel and sand, and it must be at its extreme depth five feet below the level of the stream in which it is made: each bed of about three yards in length, must be formed on a gradient of one inch to a foot or eighteen inches. Towards the upper part of the inclined plane, the salmon spawn impregnated, must be deposited and well covered in under the gravel and sand. The inclined plane is necessary to give rapidity to the current of water, and that is necessary to the vivification of the ova. A sort of sluice should be placed outside the upper grating of the beds to regulate the flow of water, to dam it off when there are floods, and to let it run freely when there are none. The depth of water in the deepest parts of the beds should not exceed three feet. Each bed should have its separate top and bottom grating. The beds should be formed by banks not so much shaded by trees, or over-hanging rocks or cliffs as to prevent the 
rays of the sun from oxygenating the water flowing over the deposited ova. The ova are to be taken from fish whilst in the act of naturally spawning on shallows not far distant from the artificial beds. I have written elsewhere on this most interesting subject,-"We must avoid capturing at random (a large casting net should be used) any pair of fish we may see on the spawning bed, because many consorted males and females are to be seen hovering about the spawning grounds several days before they begin depositing their spawn. If from such fish ova be expressed by manipulation, they will be found in an immature state, their pores not as yet open for the reception or absorption of the milt, and expressing it over them then will not produce impregnation. On the contrary, when a pair, of course male and female, that have commenced spawning are captured, their ova and milt will be found in the mature state required, or at least a portion of them. A vessel, can, pail, or small tub, must be ready, containing a small portion of clean gravel from the river, and. as much river water as will cover the gravel and the spawn about to be placed in it. The female salmon just captured, must be held up by the head over the vessel with one hand, whilst with the other hand gentle pressure is made down the belly of the fish. This pressure will cause the expulsion of all the ova that are mature, which will be received in the vessel. The male fish is then to be held and pressed in the same way, which will cause the emission of mature milt into the vessel. The fish are then to be restored to their native element, in which, if the manipulator be not a rough one, they will speedily recover, and when the remaining spawn, not artificially forced from them, becomes mature, they will deposit it as if nothing had happened. Having expressed ova and milt into the vessel, it must be shaken so that gravel, water, milt and ova, be properly mixed, and that no ova escape from coming into contact with portions of the milt. If any do, they will not be impregnated. On the contrary, the ova that are touched by the milt are impregnated, and if properly cared for, will in due time produce young salmon."

The ova, impregnated after the manner stated, must be placed in a little longitudinal trench, five inches deep, made in the artificial bed at the shoulder of the inclined plane. It must be spread at the bottom of the trench and covered over loosely with gravel. The gravel must not be pressed down on the ova, but it must be left in just such a loose state as will allow the running water to percolate through it and constantly pass over the ova. If they be deposited in September, and October, November, and December be mild, they will be hatched in the latter month, but if the weather be cold and frosty, they will not be incubated before the latter end of January, or the beginning of February. The young fish should be fed with insects, grubs, and very small worms, and they may be set free at the age of six or eight months. They should not be left in confinement longer than eleven months. Some of them should be marked, with fry of the same age naturally bred in the river, the marking being different, in order to determine whether there has been any difference in growth when they return from the sea in a grilse state. Ova artificially impregnated may be conveyed to rivers hundreds 
of miles apart, but during the transit the water in the vessel should be renewed every morning. In constructing the walls of salmon beds no lime must be used. They must be "dry-built," and strongly, with a proper admixture of large and small stones.

I have now done with the natural history of salmon, and must show how it is to be angled for. The only pleasant and surely successful way of angling for salmon is with the artificial fly. The young fly-fisher for salmon has four principal parts to learn-to throw the fly and line, to work the fly against the water, to hook a fish, and finally, to play him within reach of landing-net or gaff. I advise the aspirant to salmon proficiency to commence by fishing for salmon-trout and grilse. The former he will find in abundance in the County Kerry rivers in spring; the latter plentifully in the rivers of Sutherland, Ross-shire, and Caithness, and in the rivers of the north-west of Ireland in July, August, and September. Why I advise thus, I'll tell. To capture those fish it requires far lighter gear than to slay the adult salmon. A rod of 16, nay, of 15 feet, will suffice, whilst a joust on fair terms with a mature fish-foe cannot be carried on without a lance 18 or 20 feet in length. The young hand can more easily wield the lighter weapon, and when he shall have mastered that, then let him handle the heavier one. Sea-trout and grilse are fished for in the same way as salmon, but with smaller flies and a lighter and shorter line, the throwing of which is to be done as follows :-The straight right shoulder cast, which is the most natural one, and should be practised when fishing from the left bank of a river, is done thus : the right hand holds the rod above the winch, the left below it; the right side is next to the river, and the right foot foremost. You bring your rod and line boldly and freely in a fine, easy, wide, semicircular sweep over your right shoulder, until your right arm is extended fully and vertically over the right side of your head, and then you send rod and line strongly forward, by communicating to the right arm sharp action, just as if you were going to strike at something elevated before you with the soft or little-finger side of your clenched hand. If all this compound action-bringing back the rod and line over the right shoulder, and then sharply sending them forward-be performed dashingly and energetically, without nervousness, stint of sweep, and strength, your fly will be driven to its destination, which should not be at first efforts much more than twenty yards distant. If you can cast that space, or say from one cricket wicket to another, well, you need not much fear but you will be able to catch sea-trout and grilse, and ultimately succeed in throwing ten yards farther, which I think far enough, all matters considered, for the great majority of useful purposes. Believe me that the best salmon-fisher is not he who throws the farthest line, but he who throws it neatly a moderate distance, and when his fly is in the water makes the best use of the pretty lure. I have seen long-limbed louts hurl or roll their fly an immense distance, three or four yards further than I could, and yet I would stake my last florin to a farthing that I would kill three fish or more for their one. The straight casts, whether from the left or right shoulder, are, generally speaking, the best. At any rate, executed by a proficient, they are always the neatest, and should, by 
beginners, be thefirstlearnt, and then practised unto perfection. They can be performed with great accuracy, so as to enable the angler to determine, almost to an inch, the precise spot on which his fly is to fall. They cause the fly and casting-line to touch the water first, and enable the fisher to commence working the fly, or showingit to the fish, sooner and better than he could do if much of the winch-line came in contact with the water simultaneously with the casting-line, or a moment before.

The effect of the straight cast is less disturbance to the water than that of any other species of cast. In fishing down a river from its right bank, you hold your rod with the left hand above the winch, and the right one beneath it; left leg foremost, and left side towards the water. You bring your rod round, by, over, and beyond the point of your left shoulder, which motion will carry the line to its full extent upwards over the bed of the river, and feeling that the line is so extended, you bring back a little, in the direction you are going to cast, the point of the rod, and making use cliefly of the action of the left arm, you propel the line forward by a motion which you make with the rod, as if you were going to strike at something hovering over the river in the direction you wish your fly to go. The forward motion of the rod will be checked at a short distance, unless you bend forward with it, and the line will be sent straight out, the fly and gut-line, to which it is attached, coming first in contact with the water. Yielding down the arms and bending the body too much with the descending rod and line, in making the cast, is a very bad habit, as it brings the point of the rod too close to the surface of the water, deadens its elastic and propelling action, and causes the line to fall in a loose and slovenly manner on the water. This left-shoulder cast is only absolutely necessary when you are fishing from beneath the right bank of a river, and have behind you impediments to a right-hand sweep of your rod and line. If the right bank be flat or shelving-if it be clear of obstructions-I can see no objection to right-shoulder casting from it. I counsel the learner to practise both ways, alternately, under all circumstances, for if he does he will become ambidexterous in the use of the rod, a great advantage and preventive of fatigue. There are other methods of throwing the line and fly, but they are difficult and should be learnt last. I do not wish to harass my pupils with difficulties at the outset. When they know how to cast well from the right and left shoulders they have then thoroughly learnt the prose of their art. The understanding of the poetry of it will steal on them unawares.

The salmon-line and fly must be thrown as straightly down the stream as possible. Casting down the current, and completely in line with it, can only be done by standing in the water at the head of the stream, or on some projecting rock, bridge, or weir. When you cast from the bank, throw slantingly down and across the stream, bringing the fly round into a line with the current without delay. The salmon-fly is worked, or " humoured" against the current, and never with it, or down it, like the trout-fly. If it were worked downwards it would roll over, on account of the general heaviness of its wings, and frighten rather than lure salmon. When worked against the current, it seems like some 
nondescript, beautiful, large insect, swimming by fits and starts a little beneath the surface of the water, and up stream. The salmon-fly must be worked towards you, up and down, and through the water, by moving the rod up and down, not very rapidly, or very high or low. The hands, grasping the rod, move up and down, just as if you were pumping leisurely with a light free-handled pump. In previous writings, I have made the following analytical remarls on humouring the salmon-fly:"When the rod and line are lifted up, so will be the fly, and the resistance it meets with from the superincumbent water against which, in an upward direction, it is forced, will press down its wings on the body, compressing, of course, the fibres of the feathery or fur material of which wings, body, and legs are made; when by the next motion, a sinking one of the rod and line, the fly goes downwards against the water, the resistance it meets with from beneath opens all the fibres of the wing-feathers and hackles, displays the different colours of each, and discloses the body and the tinsel with which it is ribbed. When by the motion that occurs between the two others, the fly is drawn towards the angler, the water presses it above and below-indeed on all sidesand all the materials of which it is male are more compressed than they are by any other motion. The motion I have ealled the sinking one, is the most attractive of the three, because its effect is fuller development of the colours of the fly, and fuller action-I may say almost separate action-of each of the fly's component parts. Now, if the up-and-down and drawing-in motions are performed roughly or rapidly, the effect, or rather one of the effects, will be, constant compression of the fibres of the wing and hackle feathers, and of the hairs, be they mohair, or pig's wool, or fur, of which the body is made. By this compression shades of colour are hidden, and nearly all the beauties of the most seductively tinted wing are obscured. The full wing and the full body are injuriously attenuated by water pressure. Certainly, no matter how rapid the upward and downward motion of the fly may be, its fibres must open as they descend against the water; but their colours are displayed for so brief a period, that the fish has not had sufficient time to distinguish them. The too rapid motion between the heaving and the setting of the fly, draws it so swiftly towards you, that few fish are fleet enough to overtake it; and if they are, they will be, I fancy, disinclined to make use of extraordinary effort to do so." It is a less fault to work the fly too slowly and gently, than too rapidly and roughly. I have seen salmon follow with open mouth a rapidly worked fly, and not being able to overtake it, turn back and descend to their lair. Whenever you see a salmon following your fly, lower your rod a little, which will cause the fly to rest, or move gently towards the fish, who, seeing it with all its fibres temptingly displayed, will, in the majority of such instances, take it eagerly.

There is no greater defect in salmon-fishing, than striking too quickly and too strongly at a rising fish. You should never strike at a fish unless you feel him, which you will not do unless you have the fly between his lips, or withinside them. The instant a salmon has taken the fly, he turns his head downwards with it, ostensibly to swallow it 
quietly in his lair. When you feel this, lift up the point of your rod, and strike with very moderate force. The salmon-rise at the fly causes a large circle about it in the water, and this circle diminishes as he descends. The majority of writers say then is the time to strike with the narrowing circle; but I tell you not to strike even then, unless at the same time you feel your fish. If you strike rapidly and roughly at a rising fish, and you miss him, he will hardly rise again. But if you do not strike at a mere rise, but take no notice, and keep working your fly on, the fish in all probability will rise and take the fly at a second or third cast, provided they be not made in too rapid succession. When a salmon rises and is not hooked, allow from seven to ten minutes to expire before you throw over him again.

Having hooked a salmon, do not press too much upon him at the outset. Hold up your rod perpendicularly and let him run away, with a taut, but not a strongly strained line, whithersoever he likes. You must only lean upon him and stop him when he makes for rocks or dangerous places. You must then present the butt of the rod towards him, throwing upon that part of it the pressure of his struggles, and when you have turned him, ease him, letting him run again with a taut line and uplifted rod. Whenever he makes for what are called "foul" spots, roots of trees, narrow rushing rapids, you must butt him severely, so as to prevent his getting into a favourite position for prolonging his struggle with you. As soon as you see him flag and show his sides, wind up your line, and moving backwards from the water your weight will bring him towards you, or rather within reach of the gaff or landing-net of your guide and assistant. I prefer, generally spealing; a large, very large landing-net to the gaff, but the latter is good for rapid work, in the hands of a clever attendant. Be in no hurry to land your fish. Young anglers, in their excitement, think they have been playing a fish for half an hour, when in reality their tussle with him has hardly been of ten minutes' duration. Take things easily, pleasantly, with good and cheery temper-no nervousness or fear, and you cannot fail to play and land your fish artistically.

Every stream and pool should be fished over slowly, and at least three different flies should be tried before any promising part of a salmon river be abandoned. When a fish rises and refuses one fly, try him with several others. There is a great chance that you will force him to fancy one at last. Fish every inch of a generally esteemed good "salmoncast." One pool fished perseveringly and artistically will afford more sport than half a dozen fished hastily and unartistically. Salmon rise best from break of day-particularly if the morning be clear and there have been no heavy dews or thick fogs - to 11 A.M., and from 6 P.M. until quite dark. Stop : there is frequently good mid-day fishing, especially when the rivers are clearing after a flood, and the day is rather sombre than sunny. When the mereury in your barometer is sinkingwhen your weather-glass has its hand shifty, pointing to rainy, foul, and so forth, angling for salmon or any other river fish is next to useless. On the contrary, mercury mounting-weather-glass hand pointing steadily to fair-you will catch fish if you are a patient angler, plying your craft 
from sunrise to sunset, allowing fair intervals for relaxation and for the refreshing of the whole physical powers by muscle-making aliments and temperate potations.-ED.」

\section{CHAPTER VIII.}

OBSERVATTONS OF THE LUCE, OR PIKE; WITH DIRECTIONS HOW TO

FISH FOR HIM.

[fourth) 迎a. ]

Pisc. The mighty Luce, or Pike is taken to be the tyrant, as the salmon is the king of the fresh waters. It is not to be doubted, but that they are bred, some by generation, and some not," as namely, of a weed called pickerel weed, unless learned Gesner be much mistaken, for he says, this weed and other glutinous matter, with the help of the sun's heat, in some particular months, and some ponds apted for it by nature, do become pikes. But, doubtless, divers pikes are bred after this manner, or are brought into some ponds some such other ways as is past mran's finding out, of which we have daily testimonies.

Sir Francis Bacon, in his " History of Life and Death," observes the pike to be the longest lived of any fresh water fish; and yet he computes it to be not usually above forty

* The simplicity of Walton, or his clildish ignorance, is here manifest. To fancy " pickerel-wee" or any other plant producing fish by means of the sun's heat, is exceedingly ridiculous, but not more so than the modern belief of many persons, that horse-hair thrown into ponds will become eels. Reader, all river fish have productive spawn. All female fish have ova or eggs, commonly called the "hard-roe;" all male river fish have milts, usually named the soft roe. Unless the former be impregnated by the latter, there will be no reproduction. The salmon tribe deposit their spawn beneath gravel-beds; the carp tribe on and amongst the subaqueous portions of aquatic plants to which the spawn adheres by its inherent viscous properties. Mr. Blaine (Encyclopedia of Rural Sports, p. 1102), accurately states:- "Jack and pike spawn either in March or April, according to the forwardness of the spring, or temperature of the atmosphere, as well as the situation of the water. 'They retire for the reproductive purpose in pairs, quitting the rivers for the creeks and ditches. When confined in still waters they seek the stillest parts of them, and frequently occupy a mudbed, or remain towards the edges or shallows, depositing their spawn among aquatic plants, of which the reed and rush varieties are favourites. The male may be seen during this time accompanying the female with much attention, and when the fecundating milt has been deposited over the ova, the pair retire into deep water, and seem to feel no further solicitude for the result of the process." See the end of this chapter for other observations on the pike.-ED. 
years; and others think it to be not above ten years; and yet Gesner mentions a pike taken in Swedeland, in the year 1449, with a ring about his neck, declaring he was put into that pond by Frederick the Second, more than two hundred years before he was last taken, as by the inscription in that ring, being Greek, was interpreted by the then Bishop of Worms.* But of this no more but that it is observed, that the old or very great pikes have in them more of state than goodness; the smaller or middle-sized pikes being, by the most and choicest palates, observed to be the best meat : and, contrary, the eel is observed to be the better for age and bigness.

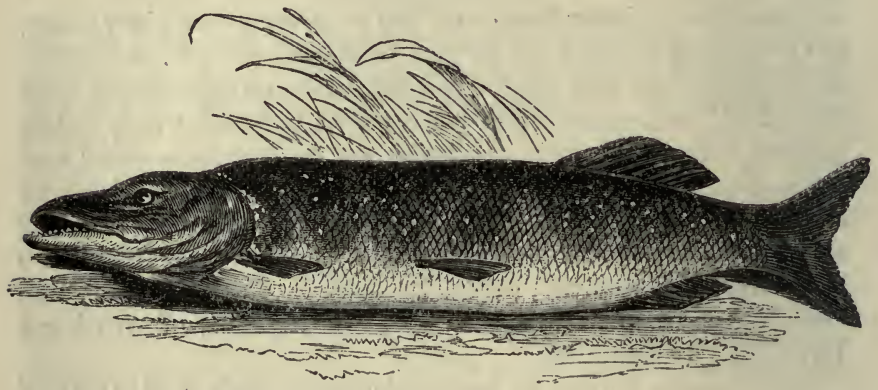

All pikes that live long prove chargeable to their keepers, because their life is maintained by the death of so many other fish, even those of their own kind; which has made him by some writers to be called the tyrant of the rivers, or the freshwater wolf, by reason of his bold, greedy, devouring disposition; which is so keen, as Gesner relates a man going to a pond, where it seems a pike had devoured all the fish, to water his mule, had a pike bit his mule by the lips; to which

* The story is told (more correctly) by Hakewill, who, in his " Apologie of the Power and Providence of God," fol. Oxf. 1635, part i. p. 145, says, " I will close up this chapter with a relation of Gesner's in his epistle to the Emperor Ferdinand, prefixed before his booke De Piscibus, touching the long life of a pike which was cast into a pond or poole near Hailebrune in Suabia, with this inscription engraven upon a collar of brass fastened about his necke, "Ego sum ille piscis huic stagno omnium primus impositus per mundi rectoris Frederici Secundi manus, 5 Octobris, anno 1230' I am that fish which was first of all cast into this poole by the hand of Fredericke the Second, governor of the world, the fifth of October, in the year 1230.-He was again taken up in the year 1497 ; and by the inscription, it appeared he had then lived there 267 yeares." $-\mathrm{H}$. 
the pike hung so fast, that the mule drew him out of the water, and by that accident the owner of the mule angled out the pike. And the same Gesner observes, that a maid in Poland had a pike bit her by the foot, as she was washing clothes in a pond. And I have heard the like of a woman in Killingworth pond, not far from Coventry. But I have been assured by my friend Mr. Seagrave, of whom I spake to you formerly, that keeps tame otters, that he hath known a pike in extreme hunger fight with one of his otters for a carp that the otter had caught, and was then bringing out of the water. I have told you who relate these things, and tell you they are persons of credit; and shall conclude this observation, by telling you what a wise man has observed, "It is a hard thing to persuade the belly, because it has no ears."*

* Bowlker, in his Art of Angling, gives the following instance of the exceeding voracity of this fish: "My father catched a pike in Barn-Meer, (a large standing water in Cheshire) was an ell long and weighed thirty-five pounds, which he brought to the Lord Kholmondely: his lordship ordered it to be turned into a canal in the garden, wherein were abundance of several sorts of fish. About twelve months after, his lordship draw'd the canal, and found that this overgrown pike had devoured all the fish, except one large carp, that weighed between nine and ten pounds, and that was bitten in several places. The pike was then put into the canal again, together with abundance of fish for him to feed upon, all which he devoured in less than a year's time; and was observed by the gardener and workmen tliere, to take the ducks and other water-fowl under water: whereupon they shot magpies and crows, and threw them into the caual, which the pike took before their eyes: of this they acquainted their lord, who thereupon ordered the slaughtermen to fling in calves' bellies, chickens' guts, and such like garbage to him, to prey upon; but being soon after neglected, he died as supposed for want of food." The following relation was inserted as an article of news in one of the London papers, 2nd Jan. 1765. Extract of a letter from Littleport, Dec. 17.- "About ten days ago, a large Pike was cauglit in the river Ouse, which weighed upwards of twenty-eight pounds, and was sold to a gentleman in the neighbourhood for a guinea. As the cook-maid was gutting the fish, she found, to her great astonishment, a watch with a black ribbon, and two steel seals annexed, in the body of the pike; the gentleman's butler, upon opening the watch, found the maker's name, Thomas Cranefield, Burnham, Norfolk. Upon a strict enquiry, it appears that the said watch was sold to a gentleman's servant, who was unfortunately drowned about six weeks ago, in his way to Cambridge, between this place and South-Ferry. The watch is still in the possession of Mr. John Roberts, at the Cross Keys, in Littleport, for the inspection of the public." And this is in the same paper, the 25 th of the same month and year. "On Tuesday last, at Lillishall lime-works, near Newport, a pool about nine yards deep, which has not yet been fished for ages, was let off by means of a level brought up to drain the works, when an enormous pike was found; he was drawn out by a rope fastened round his head and gills, amidst hundreds of spectators, in which service a great many men were employed : he weighed upwards of 170 pounds, and is thought to be the largest ever seen. Some time ago, the clerk of the parish was trolling in the above pool, when his bait was seized by this furious creature, which, by a sudden jerk, pulled him in, and doubtless would have devoured him also, had he not by wonderful agility and dexterous 
But if these relations be disbelieved, it is too evident to bo doubted, that a pike will devour a fish of his own kind that shall be bigger than his belly or throat will receive, and swallow a part of him, and let the other part remain in his mouth till the swallowed part be digested, and then swallow that other part, that was in his mouth, and so put it over by degrees ; which is not unlike the ox, and some other beasts, taking their meat, not out of their mouth immediately into their belly, but first into some place betwixt, and then chew it, or digest it by degrees after, which is called chewing the cud. And, doubtless, pikes will bite when they are not hungry; but, as some think, even for very anger, when a tempting bait comes near to them.

And it is observed that the pike will eat venomous things, as some kind of frogs are, and yet live without being harmed by them ; for, as some say, he has in him a natural balsam, or antidote against all poison. And he has a strange heat, that though it appears to us to be cold, can yet digest or put over any fish-flesh, by degrees, without being sick. And others observe that he never eats the venomous frog till he have first killed her, and then, as ducks are observed to do to frogs in spawning time, at which time some frogs are observed to be venomous, - so thoroughly washed her, by tumbling her up and down in the water, that he may devour her without. danger. And Gesner affirms that a Polonian gentleman did faithfully assure him, he had seen two young geese at one time in the belly of a pike. And doubtless a pike, in his height of hunger, will bite at and devour a dog that swims in a pond; and there have been examples of it, or the like : for,

swimming, escaped the dreadful jaws of this voracious animal." In Dr. Plot's History of Staffordshire, 246, are sundry relations of pike of great magnitude, one in particular caught in the Thame, an ell and two inches long. The following story, containing further evidence of the voracity of this fish, with the addition of a pleasant cireumstance, I met with in Fuller's Worthies, Lincolnshire, page 144. "A cub fox, drinking out of the river Arnus, in Italy, had his head seized on by a mighty pike, so that neither could free themselves, but were ingrappled together. In this contest a young man runs into the water, takes them out both alive, and carrieth them to the Duke of Florence, whose palace was hard by. The porter would not admit him without promising of sharing his full half in what the duke should give him; to which he (hopeless otherwise of entrance) condescended; the duke, highly affected with the rarity, was about giving him a good reward, which the other refused, desiring his highness would appoint one of his guard to give him a hundred lashes, that so his porter might have fifty, according to his composition. And here my intelligence leaveth me, how much farther the jest was followed."-H. 
as I told you, "The belly has no ears when hunger comes upon it."

The pike is also observed to be a solitary, melancholy, and a bold fish: melancholy because he always swims or rests himself alone, and never swims in shoals or with company, as roach and dace and most other fish do ; and bold, because he fears not a shadow, or to see or be seen of anybody, as. the trout and chub and all other fish do.

And it is observed by Gesner, that the jaw-bones and hearts and galls of pikes are very medicinable for several diseases; or to stop blood, to abate fevers, to cure agues, to oppose or expel the infection of the plague, and to be many ways medicinable and useful for the good of mankind: but he observes, that the biting of a pike is venomous, and hard to be cured. And it is observed, that the pike is a fish that breeds but once a year ; and that other fish, as namely loaches, do breed, oftener, as we are certain tame pigeons do almost every month ; and yet the hawk, a bird of prey, as the pike is of fish, breeds but once in twelve months. * And you are to note, that his time of breeding, or spawning, is usually about the end of February, or somewhat later, in March, as the weather proves colder or warmer; and to note, that his manner of breeding is thus: a he and a she pike will usually go together out of a river into some ditch or creek, and that there the spawner casts her eggs, and the melter hovers over her all that time that she is casting her spawn, but touches her not. $\uparrow$

* Walton here hints at a dispensation of Providence, by which animals of prey are rendered less productive of their species than others, particularly than those living things that furnish food for man. There are numerous exceptions. Animals, that come under the denomination of "vermin," are in many instances exceedingly prolific; far more so than the useful cow and sheep. The salmon, so valuable as an edible, does not spawn more frequently than the pike; nor does the pheasant breed oftener than the hawk, though it does more productively. Animals of prey abound in the uninhabited forest and desert, and if some are very rare, and others extinct, in populous countries, we must impute the fact to the destructive devices of man, rather than to limited natural powers of productiveness.-ED.

+ Very late discoveries of naturalists contradict this hypothesis concerning the generation of fishes, and prove that they are produced by the conjunction of the male and female, as other animals are. See the "Philosophical Transactions," Vol. XLVIII. Part II., for the year 1754, p. 870.-H.

[Discoveries later still, in the shape of repeated experiments, have proved that Walton was more correct than the "Philosophic Transactions" for the year 1754. The hypothesis that fish-we specifically refer to river fish- "are produced by the conjunction of the male and female, as other animals are," is. rejected by all eminent modern naturalists. No sexual conjunction takes place. The female fish deposits her spawn or ova, which the male fish fecundates by 
I might say more of this, but it might be thought curiosity or worse, and shall therefore forbear it ; and take up so much of your attention as to tell you, that the best of pikes are noted to be in rivers; next, those in great ponds or meres ; and the worst, in small ponds.

But before I proceed farther, I am to tell you, that there is a great antipathy betwixt the pike and some frogs : and this may appear to the reader of Dubravius, a bishop in Bohemia, who, in his book "Of Fish and Fish-ponds,"* relates what he says he saw with his own eyes, and could not forbear to tell the reader, which was :-

"As he and the Bishop Thurzo were walking by a large pond in Bohemia, they saw a frog, when the pike lay very sleepily and quiet by the shore side, leap upon his head; and the frog having expressed malice or anger by his swollen cheeks and staring eyes, did stretch out his legs and embraced the pike's head, and presently reached them to his eyes, tearing with them and his teeth, those tender parts : the pike moved with anguish, moves up and down the water, and rubs himself against weeds and whatever he thought might quit him of his enemy; but all in vain, for the frog did continue to ride triumphantly, and to bite and torment the pike, till his strength failed, and then the frog sunk with the pike to the bottom of the water; then presently the frog appeared again at the top and croaked, and seemed to rejoice like a conqueror; after which he presently retired to his secret hole. The bishop, that had beheld the battle, called his

emitting upon it his spawn or milt. The reader will remark, that Walton has already said, at the beginning of this chapter, of pike, "Tis not to be doubted but that they are bred, some by generation, and some not." In the present passage :- "A he and she-pike will usually go together out of a river into some ditch or creek, and there the spawner casts her eggs, and the milter hovers over her all that time she is casting her spawn, but touches her not"- he sets. himself right, and gives the real process of pike re-production. One of Walton's greatest errors is, that he places such confidence in what were in his day called learned writers, particularly German ones. They were as bad naturalists in his time as they are now, and for the excellent reason that they indulge in day-dreams about the abnormal habits and singular instincts of animalia, instead of trying to account for them by facts derived from actual. observation. The Tudesque theories about river-fish are the vaguest imaginable; and if Walton had relied more on his own experience and good sense, than on the dreaminess of Gesner, and similar gobe-mouche naturalists, the "Complete Angler" would not have been the medium of conveying to credulous readers statements concerning the habits of fish, birds, and quadrupeds, as silly as they are opposed to all the recognised laws of nature.-ED.]

* 'Translated into English in 1599, by George Churchey, of Lyon's Inn. 
fishermen to fetch his nets, and by all means to get the pike that they might declare what had happened : and the pike was drawn forth, and both his eyes eaten out; at which when they began to wonder, the tisherman wished them to forbear, and assured them he was certain that pikes were often so served."

I told this, which is to be read in the sixth chapter of the first book of Dubravius, unto a friend, who replied, "It was as improbable as to have the mouse scratch out the cat's eyes." But he did not consider, that there be fishing frogs, which the Dalmatians call the water-devil, of which I might tell you as wonderful a story; but I shall tell you, that 'tis not to be doubted, but that there be some frogs so fearful of the watersuake, that, when they swim in a place in which they fear to meet with him, they then get a reed across into their mouths, which, if they two meet by accident, secures the frog from the strength and malice of the snake; and note, that the frog usually swims the fastest of the two.

And let me tell you, that as there be water and land-frogs, so there be land and water snakes. Concerning which, take this observation, that the land-snake breeds and hatches her eggs, which become young snakes, in some old dunghill, or a like hot place; but the water-snake, which is not venomous, and, as I have been assured by a great observer of such secrets, does not hatch, but breed her young alive, which she does not then forsake, but bides with them, and in case of danger will take them into her mouth and swim away from any apprehended danger, and then let them out again when she thinks all danger to be passed; these be accidents that we anglers sometimes see, and often talk of.

But whither am I going? I had almost lost myself, by remembering the discourse of Dubravius. I will therefore stop here, and tell you, according to my promise, how to catch the pike.

His feeding is usually of fish or frogs, and sometimes a weed of his own called pickerel-weed, of which I told you some think pikes are bred; for they have observed, that where none have been put into ponds, yet they have there found many, and that there has been plenty of that weed in those ponds, and [they think] that that weed both breeds and feeds them: but whether those pilkes so bred will ever breed by generation as the others do, I shall leave to the disquisitions of men of more curiosity and leisure than I 
profess myself to have : and shall proceed to tell you, that you may fish for a pike, either with a ledger or a walkingbait; and you are to note, that I call that a ledger-bait, which is fixed or made to rest in one certain place when you shall be absent from it ; and I call that a walking-bait which you take with you, and have ever in motion. Concerning which two, I shall give you this direction, that your ledgerbait is best to be a living bait (though a dead one may catch), whether it be a fish or a frog : and that you may make them live the longer, you may, or indeed you must, take this course :

First, for your live-bait. Of fish, a roach or dace is, I think, best and most tempting (and a perch is the longest lived on $a$ hook ;) and having cut off his fin on his back, which may be done without hurting him, you must take your knife, which cannot be too sharp, and between the head and the fin on the back, cut or make an incision, or such a scar, as you may put the arming-wire of your hook into it, with as little bruising or hurting the fish as art and diligence will enable you to do ; and so carrying your arming-wire along his back, unto or near the tail of your fish, between the skin and the body of it, draw out that wire or arming of your hook at another scar near to his tail : then tie him about it with thread, but no harder than of necessity to prevent hurting the fish ; and the better to avoid hurting the fish, some have a kind of probe to open the way, for the more easy entrance and passage of your wire or arming: but as for these, time and a little experience will teach you better than I can by words; therefore I will for the present say no more of this, but come next to give you some directions how to bait your hook with a frog.

VEN. But, good Master, did you not say even now, that some frogs are venomous, and is it not dangerous to touch them?

PIsc. Yes ; but I will give you some rules or eautions concerning them. And first, you are to note, that there are two kinds of frogs ; that is to say, if I may so express myself, a flesh and a fish-frog : by flesh-frogs, I mean frogs that breed and live on the land; and of these there be several sorts also, and of several colours, some being speckled, some greenish, some blackish or brown : the green frog, which is a small one, is by Topsell taken to be venomous, and so is the padock or frog padock, which usually keeps or breeds on the land, and is very large, and bony and big, especially the she- 
frog of that kind; yet these will sometimes come into the water, but it is not often; and the land-frogs are some of them observed by him to breed by laying eggs, and others to breed of the slime and dust of the earth, and that in winter they turn to slime again, and that the next summer that very slime returns to be a living creature; this is the opinion of Pliny, and Cardanus* (in his tenth book De Subtilitate) undertakes to give a reason for the raining of frogs : but if it were in my power, it should rain none but water-frogs, for those I think are not venomous, especially the right water-frog, which about February or March breeds in ditches by slime, and blackish eggs in that slime, about which time of breeding the he and she-frogs are observed to use divers summersaults, and to croak and make a noise, which the land-frog, or padockfrog, never does. Now of these water-frogs, if you intend to fish with a frog for a pilke, you are to choose the yellowest that you can get, for that the pike ever likes best. And thus use your frog, that he may continue long alive :

Put your hook into his mouth, which you may easily do from the middle of April till August; and then the frog's mouth grows up, and he continues so for at least six months without eating, but is sustained none but He whose name is Wonderful knows how: I say, put your hook, I mean the arming-wire, through his mouth and out at his gills; and then with a fine needle and silk sew the upper part of his leg, with only one stitch, to the arming-wire of your hook ; or tie the frog's leg, above the upper joint, to the arming-wire ; and, in so doing, use him as though you loved him, t that is, harm hin as little as you may possibly, that he may live the longer.

And now, having given you this direction for the baiting your ledger-hook with a live fish or frog, $\neq$ my next must be to

* Hieronymus Cardanus, an Italian physician, naturalist, and astrologer, well-known by the many works he has published : he died at Rome 1576. It is said that he had foretold the day of his death, and that, when it approached, he suffered himself to die of hunger to preserve his reputation.-H.

$\dagger$ It is this expression, with the instructions given in the paragraph, on which is mainly founded the charge of cruelty against Walton, and no doubt gave rise to the lines of Byron so frequently quoted:-

"That quaint, old, cruel coxcomb, in his gullet Should have a hook, and a small trout to pull it." "Don Juan," canto xiii.

$\ddagger$ Ledger-hook. The name is now applied to a certain sort of apparatusthe best-used for fishing for barbel. In my notes about the end of chapter the $14 \mathrm{th}$, which treats of the barbel, the ledger-hook or line is fully described. -ED. 
tell you how your hook thus baited must or may be used, and it is thus : Having fastened your hook to a line, which, if it be not fourteen yards long, should not be less than twelve, you are to fasten that line to any bough near to a hole where a pike is, or is likely to lie, or to have a haunt, and then wind your line on any forked stick, all your line, except half a yard of it, or rather more, and split that forked stick with such a nick or notch at one end of it as may keep the line from any more of it ravelling from about the stick than so much of it as you intend; and choose your forked stick to be of that bigness as may keep the fish or frog from pulling the forked stick under the water till the pike bites; and then the pike having pulled the line forth of the cleft or nick of that stick in which it was gently fastened, he will have line euough to go to his hold and pouch the bait; and if you would have this ledger-bait to keep at a fixed place, undisturbed by wind or other accidents, which may drive it to the shore-side, (for you are to note, that it is likeliest to catch a pike in the midst of the water,) then hang a small plummet of lead, a stone, or piece of tile, or a turf in a string, and cast it into the water with the forked stick, to hang upon the ground, to be a kind of anchor to keep the forked stick from moving out of your intended place till the pike come. This I take to be a very good way, to use so many ledger-baits as you intend to make trial of.

Or if you bait your hooks thus with live fish or frogs, and in a windy day, fasten them thus to a bough or bundle of straw, and by the help of that wind can get them to move across a pond or mere, you are like to stand still on the shore and see sport presently if there be any store of pikes : or these live baits may make sport, being tied about the body or wings of a goose or duck, and she chased over a pond : and the like may be done with turning three or four live baits thus fastened to bladders, or boughs, or bottles of hay or flags, to swim down a river, whilst you walk quietly alone on the shore, and are still in expectation of sport. The rest must be taught you by practice, for time will not allow me to say more of this kind of fishing with live baits.

And for your dead bait for a pike, for that you may be taught by one day's going a fishing with me, or any other body that fishes for him, for the baiting your hook with a dead gudgeon or a roach, and moving it up and down the water, is too easy a thing to take up any time to direct you 
to do it; and yet, because I cut you short in that, I will commute for it by telling you that that was told me for a secret : it is this :

Dissolve gum of ivy in oil of spike, and therewith anoint your dead bait for a pike, and then cast it into a likely place, and when it has lain a short time at the bottom, draw it towards the top of the water, and so up the stream, and it is more than likely that you have a pike follow with more than common eagerness.

And some affirm, that any bait anointed with the marrow of the thigh-bone of an hern, ${ }^{*}$ is a great temptation to any fish.

These have not been tried by me, but told me by a friend of note, that pretended to do me a courtesy; but if this direction to catch a pike thus do you no good, yet I am certain this direction how to roast him when he is caught is choicely good, for I have tried it, and it is somewhat the better for not being common; but with my direction you must take this caution, that your pike must not be a small one, that is, it must be more than half a yard, and should be bigger.

First, open your pike at the gills, and if need be, cut also a little slit towards the belly; out of these take his guts and keep his liver, which you are to shred very small with thyme, sweet-marjoram, and a little winter-savory : to these put some pickled oysters, and some anchovies, two or three, both these last whole ; for the anchovies will melt, and the oysters should not: to these you must add also a pound of sweet butter, which you are to mix with the herbs that are shred, and let them all be well salted : if the pike be more than a yard long, then you may put into these herbs more than a pound, or if he be less, then less butter will suffice : these being thus mixed with a blade or two of mace, must be put into the pike's belly, and then his belly so sewed up, as to keep all the butter in his belly, if it be possible : if not, then as much of it as you possibly can; but take not off the scales : then you are to thrust the spit through his mouth out at his tail ; and then take four, or five, or six split sticks or very thin laths, and a convenient quantity of tape or filleting : these laths are to be tied round about the pike's body from his head to his tail, and

* No doubt Walton means the well-known bird,the heron, a great destroyer of fish, and hence, apparently, the notion that its marrow had some odoriferous attraction. Anointing any fish dead-bait for pike or for perch, or any other fish, is more superfluous, if possible, than gilding the purest Australian gold nugget.-ED. 
the tape tied somewhat thick to prevent his breaking or falling off from the spit: let him be roasted very leisurely, and often basted with claret wine and anchovies and butter mixed together, and also with what moisture falls from him into the pan : when you have roasted him sufficiently, you are to hold under him, when you unwind or cut the tape that ties him, such a dish as you purpose to eat him out of ; and let him fall into it with the sauce that is roasted in his belly; and by this means the pike will be kept unbroken and complete : then, to the sauce which was within, and also that sauce in the pan, you are to add a fit quantity of the best butter, and to squeeze the juice of three or four oranges : lastly, you may either put into the pike with the oysters two cloves of garlick, and take it whole out, when the pike is cut off the spit; or to give the sance a haut-gout let the dish into which you let the pike fall be rubbed with it: the using or not using of this garlick is left to your discretion.-M. B.

This dish of meat is too good for any but anglers, or very honest men; and I trust you will prove both, and therefore I have trusted you with this secret.

Let me next tell you, that Gesner tells us there are no pikes in Spain ; and that the largest are in the lake Thrasymene in Italy; and the next, if not equal to them, are the pikes of England; and that in England, Lincolnshire boasteth to have the biggest. Just so doth Sussex boast of four sorts of fish; namely, an Arundel Mullet, a Chichester Lobster, a Shelsey Cockle, and an Amerley Trout.

But I will take up no more of your time with this relation; but proceed to give you some observations of the Carp, and how to angle for him, and to dress him, but not till he is caught.

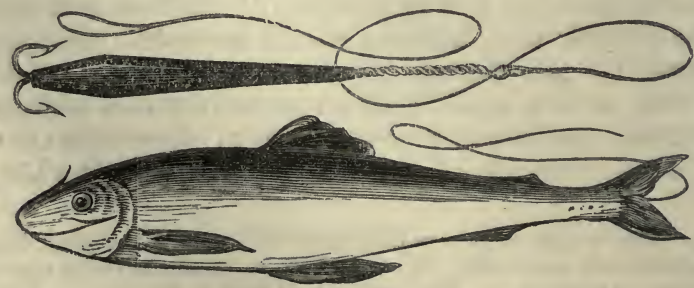

GORGA-EOOK 
[There is no fish better known to London anglers than the jack and pike. When the pike weighs less than 4lbs. it is technically called in England a jack; above that weight a pike. Its right vernacular name, however, at all ages and sizes is pike. Scientifically it is called Esox Lucius, and Dr..Fleming describes it thus:--body, olive above, with yellow spots; beneath white, with black spots; body of nearly an equal thickness, suddenly decreasing behind the dorsal and anal fins. Of this notorious fish I painted some years ago a fancy miniature, which has been extensively admired and copied. Here it is. "The pike, commonly called jack, when under 3lbs. or 4lbs. in weight, is a well-known fish; like many of ns, better known than trusted or treated. He is a greedy, unsociable, tyrannising savage, and is hated like a Blue Beard. Every body girds at him with spear, gaff, hook, net, snare, and even with powder and shot. He has not a friend in the world. The horrible gorge hook is specially invented for the torment of his maw. Notwithstanding, he fights his way vigorously, grows into immense strength, despite his many enemies, and lives longer than his greatest foe, man. His voracity is unbounded; and, like the most accomplished corporate officers, he is nearly omnivorous, his palate giving the preference however, to fish, flesh, and fowl. Dyspepsia never interferes with his digestion; and he possesses a qrality that would have been valuable at La Trappe-lie can fast without inconvenience for a se'nnight. He can gorge himself then to beyond the gills without the slightest derangement of the stomach. He is shark and ostrich combined. His body is comely to look at; and if he would hide his head-by no means a diminished one-his green and silver vesture would attract many admirers. His intemperate habits, however, render him an object of disgust and dread. He devours his own children; but, strange to say, likes better (for eating) the children of his neighbours. Heat spoils his appetite; cold sharpens it. I envy the pike constitution." There are more anecdotes in written and oral circulation, about this furious fish than about any other denizen of our fresh waters. Those relative to his ferocity I believe for the most part. No wonder that he should be always a-hungered. He will digest a small roach, dace, or trout in half an hour. It requires a large fish to be pouched to render torpid his muscular action, or arrest the action of his most strongly and rapidly dissolving gastric juices. The rascal's stomach is rarely empty, and therefore there occurs continually a large absorption of nutritious matter into the system. Hence the rapid growth and large size of pike. In my opinion the salmon is a greater eater than the pike. But he feeds with a prettier mouth, silently and unobserved, and does not gobble with avid eyes and crunching jaws like the pike, so nobody notices the large quantity of food he "puts away" in a gentlemanlike manner. The salmon is a gourmet, the pilse is a gourmand; which, being interpreted, means that the former is a nice, though a large feeder; the latter a gluttonous muncher, even of garbage. The one would be a Beau Brummel at table, the other a Dr. Samuel Johnson. I do not believe the story of Frederick the Second's pike mentioned in the second page of the prececling chapter, nor do I believe Mr. Seagrave's story following 
the other, "that he hath known a pike, in extreme hunger, fight with one of his (tame) otters for a carp, that the otter had canght, and was then bringing out of the water." If a pike were so fool-hardy as to make any such assault, the otter would have dropped the lesser carp, and speedily captured and with the greatest ease the bigger and best prizethe pike. I believe that the largest pike ever caught in the British Isles was that caught many years ago, and the weight of which was about 92lbs., in the river Shannon, by some visitors at Portumna Castle, the family seat of the Marquis of Clanricarde. I never saw a pike that weighed more than 33lbs. ; but Mr. Christopher Grove, of Bond-st., his cousin, Mr. T. Grove, of Charing-cross, and Mr. Sweeting; of Cheapside, all celebrated fishmongers, tell me they have frequently Dutch pike weighing upwards of $40 \mathrm{lbs}$, and sometimes reaching $50 \mathrm{lbs}$.

There are many methods of angling for pike. I shall describe the best. The easiest, simplest, and in many instances the best, is called " sinking and roving." It is practised with a live fish-bait-a gudgeon, dace, roach, or trout. For large pike, a dace, roach, or trout, weighing 6oz. is not too big a bait. As a general rule, large fish will not trouble themselves with small baits. In sinking and roving you pass your hook through the skin, taking in a little of the flesh, by the side and at the root of the dorsal fin of your live bait. The hook is to be attached to one yard and a half of stout gimp, which is to be heavily leaded to keep down the bait to within a foot or two of the bottom of the water. On your line is to be a large cork float, to prevent the bait from sinking to the very bottom, or swimming about too freely, and to tell you when you have a bite, or technically speaking a "run." Your rod must be stout and strong, and your winch line must consist of 80 yards of strong, platted silk line, prepared with oil and varnish. Such a line will answer for spinning or trolling for pike. The more lively your bait the better. Let it swim about here and there, by aquatic plants and roots of trees, and when you have a "run" do not strike instantly. Let the pike run off with the bait, giving him line to enable him to do so without check. In from five to ten minutes he will swallow or "pouch" the bait, and then you must strike your fish smartly and play him vigorously. When the line is suddenly slackened a little, and has a quivering motion communicated to it, then you may be sure that the bait is pouched. On the contrary, as Capt. Williamson says :- "when you see a great number of very small bubbles rising from the spot where you know, by the direction of the line, the jack is lying, you should forbear from striking, it being a certain sign that he has not pouched your bait." A pike seizes its prey by the middle, then swims off with it, to its lair, turns it headforemost in his mouth and then swallows it, rapidly or slowly according to the state of his appetite. Pike seem sometimes to play in sheer wanton cruelty with the fish they have seized, as cats do with mice. Taylor in an old, and, as far as it goes good, treatise on angling, writes :- "The pike will, as soon as he has seized the bait, run to his hold to pouch or swallow it; allow him, therefore, five minutes to do so (unless the line slackens before that time, which is a signal that he has already done it), and then strike. But if after he has run off with the 
bait, he makes scarcely any stay with it at his hold, but goes off with it again, you should not strike until he has rested a second time, allowing him still about five minutes; but if he should run off a third time before the five minutes are expired, draw a tight line, and strike him instantly."

There is another method of pike-fishing, called "snap" fishing. You tie two large hooks, back to back, with their barbs pointing different ways. Near the top of their shanks you tie a small hook, which is to be inserted by the root of the dorsal fin of the live bait, and the two large hooks are to lie down by the side of the bait, their bends not extending below the belly of the dace or roach you fish with, but just even with it. When you have a run, allow no time for pouching, but strike immediately. There is another hook, called the "spring-snap," shaped like the latter, but the backs of the hooks are held together by means of a spring, which gives when a fish is struck, and then both hooks spring suddenly and strongly out, and fix themselves inside the mouth of the pike. The spring-snap is generally used with a dead bait, a roach being the best one for the purpose. The snap-hooks are put in requisition in the summer and early autumn months, when pike, finding plenty of fish food in the rivers, are not very pressing in pursuit of the angler's lures. If pike seize them then, they often reject them without pouching, so that it is necessary to strike immediately. Hence the invention of snap-hooks.

Trolling with the gorge-hook, or spinning for pike, are the two most artistical ways of angling for him. I have explained how spinning is to be practised in my remarks at the end of Chapter V., on trout-fishing. Spinning for trout, pike, perch, and salmon is done in precisely the same way. The spinning-flight of hooks for pike must be double the size of that used for the capture of tront. Trolling is practised with the gorgehook, for a representation of which see the end of this chapter. The gorge-hook, or hooks, are fashioned thus:-Take two eel-hooks, and whip them back to back, with their points outside : to their shanks attach a length of twisted wire, looped at the end. From three to four inches of wire will be sufficient, and over it for about two inches, beginning at the inside of the bends of the hooks, fix some lead, rounded and thick near the hook-bend, and tapering off gradually down the wire, until it becomes no thicker than it. There should not be more lead than is necessary to sink the bait. To the looped end of the wire a link of gimp a foot long should be attached, the end of which is to be placed in the eye of a baiting-needle, whose point is to be passed in at the mouth of the bait-fish, and out at the middle of the tail. Draw the link to, and the wire and lead on it will pass into the fish-bait, until their progress is arrested by the bends of the hooks stopped at the angles of the mouth of the bait. The barbs of the hooks must point upwards, never downwards. Your link, with its baited gorge-hook, is to be looped on to a gimp trace of. about a yard in length, with two swivels on it, eighteen inches apart, and the trace is to be looped on your prepared platted silk winch-line. The trolling-rod should be from ten to twelve feet in length, with a few. very large rings upon it-large enough to admit easily the top of the forefinger. The rod should be very stout, and slightly elastic; its butt 
made of well-seasoned ash, its two middle pieces of hickory, and its top of bamboo cane, tipped with about six inches of whalebone. The winch, capable of holding eighty yards of line, should be a London-made check one. Fairservice is the best maker. For salmon and trout fly-fishing, I always use one of his check winches, varying its size according to the size of the rod I use, and the fish I angle for. In a "Handbook of Angling," I have briefly described how the trolling-rod is to be handled. I say in it:- "To cast your gorge-bait, your must unroll off your winch as much line as you want to reach the distance you intend to cast to. The line must fall in free coils by your feet on the left side. Take the upper part of the coiled line in your left hand, drawing the bait within a yard or a little less of the point of your rod, which lifting with your right hand, the butt being propped against your right flank, throw upwards and forwards to your right or left if you are pond or lake fishing, and across and down stream if you are river fishing; and, simultaneously with the throw or cast, letting free the line in your left hand, the bait will be carried, if well and boldly projected, all the coiled portion of the line running through the rings freely, to that spot of the river you wish to reach, provided always that you have accurately calculated the length of line required, and uncoiled it off your winch, and coiled it at your feet accordingly. The bait having entered the water, keep it at about a distance of one-third the whole depth, if the water be deep, from the bottom, but generally speaking at mid-water in moderately deep places, and drawing in your line with the left hand by short and gentle pulls, and moving your rod's point in the same direction, try and give to the bait an attractive, if not natural motion. Do not, unless in case of emergency, lift your bait out of the water until you have worked it close to you. A pike very frequently follows the bait and seizes it almost at your feet. Repeat your cast, and go on casting, moving with each cast, until you have left no portion of the water untried. Your first cast should be into those parts of the water nearest to you, then further out, and lastly, as far to the other side of the water as you can throw. When you have a run, let the fish move off with your bait, giving time to gorge it, and strike, and act as directed in my remarks on "sinking and roving" for pike. There is one more fair and sportsman-like mode of capturing pike, viz., with a large artificial fly-a gigantic imitation of the dragon-fly. Mr. Blacker, of Dean-street, Soho, makes it to perfection. It is to be worked through the water like the salmon-fly, and should be used in pools, ponds and lakes, in mild, sombre windy weather. It answers better in Ireland and Scotland than in the waters of England.

The haunts of pike are the deep, still pools of rivers, bordered with willow trees, and having beds of bulrushes, flags, water-lilies, and other aquatic plants. In fine weather they lie just outside these beds, or a little within them, so the bait should be worked close by. In winter, they lie on these rotten plants, and in sheltered deeps. Nearly all the large lakes in Ireland abound with pike, as do the rivers that have their sources in bogs. Many of the lochs of Scotland teem with them, and they are plentiful in the meres of Norfolk and Suffolk. They are never absent from the sluggish rivers that run through our flat counties, such 
as Lincolnshire, Leicestershire, Northamptonshire, and Nottinghamshire. They do not fancy rapid rivers, and happily are absent from those mountainous streams, the habitats of the salmon and trout. There are many good pike-pools in the Thames, all the way up from Hampton to Sonning, but the best pike-water near London is the Tring reservoir, in Buckinghamshire.-ED.]

\section{CHAPTER IX.}

OBSERVATIONS ON THE CARP; WITH DIRECTIONS HOW TO FISH FOR HIM.

[fourth 国ap.]

Pisc. The Carp is the queen of rivers; a stately, a good, and a very subtle fish; that was not at first bred, nor hath been long in England, but is now naturalised. It is said, they were brought hither by one Mr. Mascal, a gentleman that then lived at Plumsted, in Sussex, a county that abounds more with fish than any in this nation.

You may remember that I told you Gesner says there are no pikes in Spain: and doubtless there was a time, about a hundred or a few more years ago, when there were no carps in England, as may seem to be affirmed by Sir Richard Baker, in whose "Chronicle" you may find these verses :

Hops and turkeys, carps and beer,

Came into England all in a year.

And doubtless, as of sea-fish the herring dies soonest out of the water, and of fresh-water fish, the trout, so, except the eel, the carp endures most hardness, and lives longest out of his own proper element. And, therefore, the report of the carp's being brought out of a foreign country into this nation is the more probable.

Carps and loaches are observed to breed several months in one year, which pikes and most other fish do not. And this is partly proved by tame and wild rabbits; and also by some ducks, which will lay eggs nine of the twelve months; and yet there be other ducks that lay not longer than about one month. And it is the rather to be believed, because you shall scarce or never take a male carp without a melt, and a female without a roe or spawn, and for the most part, very 
much, and especially all the summer season. And it is observed that they breed more naturally in ponds than in running waters, if they breed there at all; and that those that live in rivers are taken by men of the best palates to be much the better meat.

And it is observed, that in some ponds carps will not breed, especially in cold ponds; but where they will breed they breed innumerably : Aristotle and Pliny say six times in a year, if there be no pikes or pearch to devour their spawn, when it is cast upon grass, or flags, or weeds, where it lies ten or twelve days before it be enlivened.

The carp, if he have water room and good feed, will grow to a very great bigness and length; I have heard, to be much above a yard long." It is said by Jovius, who hath writ of fishes, that in the lake Iurian in Italy, carps have thriven to be more than fifty pounds weight; which is the more probable, for as the bear is conceived and born suddenly, and being born, is but short-lived, so, on the contrary, the elephant is said to be two years in his dam's belly, some think he is ten years in it, and being born, grows in bigness twenty years; and it is observed, too, that he lives to the age of a hundred years. And it is also observed that the crocodile is very long-lived, and more than that, that all that long life he thrives in bigness ; and so I think some carps do, especially in some places; though I never saw one above twenty-three inches, which was a great and a goodly fish; but have been assured there are of a far greater size, and in England too. $†$

Now, as the increase of carps is wonderful for their number, so there is not a reason found out, I think, by any, why they should breed in some ponds, and not in others of the same nature for soil and all other circumstances. And as their breeding, so are their decays also very mysterious : I have both read it, and been told by a gentleman of tried honesty, that he has known sixty or more large carps put into several ponds near to a house, where, by reason of the stakes in the ponds, and the owner's constant being near to

* The widow of the late MIr. David Garrick, of Drury-lane Theatre, once told me, that in her native country, Germany, she had seen the head of a carp served up at table, big enough to fill a large dish.-H.

† The author of the "Angler's Sure Guide" says, that he has taken carp above twenty-six inches long in rivers; and adds, that they are often seen in England above thirty inches long. 
them, it was impossible they should be stole away from him; and that when he has, after three or four years, emptied the pond, and expected an increase from them by breeding young ones (for that they might do so, he had, as the rule is, put in three melters for one spawner), he has, I say, after three or four years, found neither a young nor old carp remaining. And the like I have known of one that had almost watched the pond, and at a like distance of time, at the fishing of the pond, found, of seventy or eighty large carps, not above five or six ; and that he had forborne longer to fish the said pond, but that he saw, in a hot day in summer, a large carp swim near the top of the water with a frog upon his head; and that he, upon that occasion, caused his pond to be let diy : and I say, of seventy or eighty carps, only found five or six in the said pond, and those very sick and lean, and with every one a frog sticking so fast on the head of the said carps, that the frog would not be got off without extreme force or: kiliing. And the gentleman that did affirm this to me, told me he saw it; and did declare his belief to be, and I also believe the same, that he thought the other carps, that were so strangely lost, were so killed by the frogs, and then devoured.

And a person of honour, now living in Worcestershire, assured me he had seen a necklace or collar of tadpoles, hang like a chain or necklace of beads about a pike's neck, and to kill him; whether it be for meat or malice must be to me a question.

But $I$ am fallen into this discourse by accident, of which $I$ might say more, but it has proved longer than I intended, and possibly may not to you be considerable : I shall thercfore give you three or four more short observations of the carp, and then fall upon some directions how you shall fish for him.

The age of carps is by Sir Francis Bacon, in his "History of Life and Death," observed to be but ten years; yet others think they live longer. Gesner says, a carp has been known to live in the Palatinate above a hundred years:" but most conclude that, contrary to the pilke or luce, all carps are the better for age and bigness. The tongues of curps are noted

* Lately, viz., in one of the daily papers for the month of August, 1782, an article appeared, purporting that in the bason at Emanuel College, Camiridge, a carp was then living that had been in that water thirty-six years; which, though it had lost one eye, knew, and would constantly approach, its feeder. - H. 
to be choice and costly meat, especially to them that buy them : but Gesner says, carps have no tongue like other fish, but a piece of flesh-like fish in their mouth like to a tongue, and should be called a palate : but it is certain it is choicely good; and that the carp is to be reckoned amongst those leather-mouthed fish, which I told you have their teeth in their throat, and for that reason he is very seldom lost by breaking his hold, if your hook be once stuck into his chaps.

I told you that Sir Francis Bacon thinks that the carp lives but ten years: but Janus Dubravius has writ a book, "Of Fish and Fish-ponds," in which he says, that carps begin to spawn at the age of three years, and continue to do so till thirty : he says also, that in the time of their breeding, which is in summer, when the sun hath warmed both the earth and water, and so apted them also for generation, that then three or four male carps will follow a female : and that then, she putting on a seeming coyness, they force her through weeds and flags, where she lets fall her eggs or spawn, which sticks fast to the weeds; and then they let fall their melt upon it, and so it becomes in a short time to be a living fish : and, as I told you, it is thought that the carp does this several months in the year. And most believe that most fish breed after this manner, except the eel. And it has been observed, that when the spawner has weakened herself by doing that natural office, that two or three melters have helped her from off the weeds, by bearing her up on both sides, and guarding her into the deep. And you may note, that though this may seem a curiosity not worth observing, yet others have judged it worth their time and cost to make glass hives, and order them in such a manner as to see how bees have bred and made their honeycombs, and how they have obeyed their king, and governed their commonwealth. But it is thought that all carps are not bred by generation; but that some breed other ways, as some pikes do.

The physicians make the galls and stones in the heads of carps to be very medicinable. But it is not to be doubted but that in Italy they make great profit of the spawn of carps by selling it to the Jews, who make it into red caviare ; the Jews not being by their law admitted to eat of caviare made of the sturgeon, that being a fish that wants scales-and, as may appear in Lev. xi. 10,-by them reputed to be unclean.

Much more might be said out of him, and out of Aristotle, 
which Dubravius often quotes in his Discourse of Fishes ; but it might rather perplex than satisfy you : and therefore I shall rather choose to direct you how to catch, than spend more time in discoursing either of the nature or the breeding of this CARP, or of any more circumstances concerning him ; but

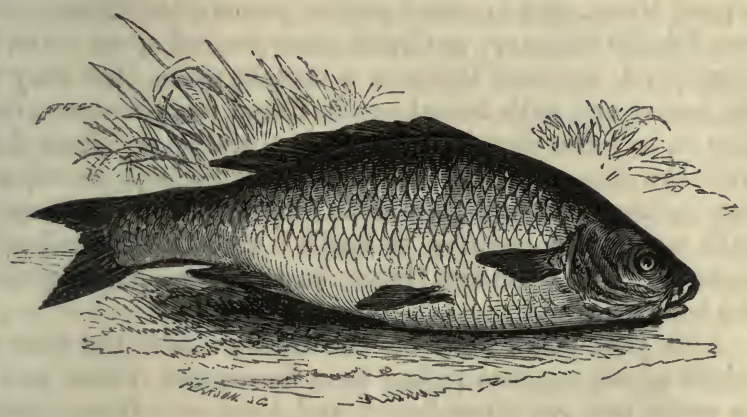

yet I shall remember you of what I told you before, that he is a very subtle fish, and hard to be caught.

And my first direction is, that if you will fish for a carp, you must put on a very large measure of patience ; especially to fish for a river-carp ; I have known a very good fisher angle diligently four or six hours in a day, for three or four days together, for a river carp, and not have a bite. And you are to note, that in some ponds it is as hard to catch a carp as in a river ; that is to say, where they have store of feed, and the water is of a clayish colour; but you are to remember I have told you there is no rule without an exception ; and therefore being possessed with that hope and patience which I wish to all fishers, especially to the carp-angler, I shall tell you with what bait to fish for him. But first, you are to know that it must be either early or late; and let me tell you, that in hot weather, for he will seldom bite in cold, you cannot be too early or too late at it. And some have been so curious as to say, the tenth of April is a fatal day for carps.

The carp bites either at worms or at paste ; and of worms I think the bluish marsh or meadow worm is best; but possibly another worm not too big may do as well, and so may a green gentle; and as for pastes, there are almost a many sorts as there are medicines for the toothachen; bu 
doubtless sweet pastes are best; I mean pastes made with honey or with sugar; which, that you may the better beguile this crafty fish, should be thrown in the pond or place in which you fish for him, some hours, or longer, before you undertake your trial of skill with the angle-rod; and doubtless if it be thrown into the water a day or two before, at several times, and in small pellets, you are the likelier, when you fish for the carp, to obtain your desired sport. Or, in a large pond, to draw them to a certain place, that they may the better and with more hope be fished for, you are to throw into it, in some certain place, either grains or blood mixed with cow-dung, or with bran; or any garbage, as chickens" guts or the like; and then some of your small sweet pellets with which you purpose to angle: and these small pellets being a few of them also thrown in as you are angling, will be the better.

And your paste must be thus made : take the flesh of a rabbit or cat cut small; and bean flour; and if that may not be easily got, get other flour; and then mix these together, and put to them either sugar, or honey (which I think better): and then beat these together in a mortar, or sometimes work them in your hands, your hands being very clean ; and then make it into a ball, or two, or three, as you like best, for your use ; but you must work or pound it so long in the mortar, as to make it so tough as to hang upon your hook, without washing from it, yet not too hard: or, that you may the better keep it on your hook, you may knead with your paste a little, and not much, white or yellowish wool.

And if you would have this paste keep all the year, for any other fish, then mix with it virgin wax, and clarified honey, and work them together with your hands before the fire; then make these into balls, and they will keep all the year.

And if you fish for a carp with gentles, then put upon your hook a little piece of scarlet about this bigness $\square$, it being soaked in or anointed with oil of peter, called by some oil of the rock; and if your gentles be put two or three days before into a box or horn anointed with honey, and so put upon your hook as to preserve them to be living, you are as like to kill this crafty fish this way as any other; but still, as you are fishing, chew a little white or brown bread in your mouth, and cast it into the pond about the place where your float swims. Other baits there be ; but these, with diligence and patient watchfulness, will do it better than any that I have ever 
practised or heard of; and yet I shall tell you, that the crumb of white bread and honey, made into a paste, is a good bait for a carp ; and you know it is more easily made. And having said thus much of a carp, * my next discourse shall be of the bream ; which shall not prove so tedious, and therefose I desire the continuance of your attention.

But, first, I will tell you how to make this carp, that is so curious to be caught, so curious a dish of meat, as shall make him worth all your labour and patience ; and though it is not without some trouble and charges, yet it will recompense both.

Take a carp, alive if possible, scour him, and rub him clean with water and salt, but scale him not; then open him, and put him, with his blood and his liver, which you must save when you open him, into a small pot or kettle; then take sweet marjoram, thyme, and parsley, of each half a handful, a sprig of rosemary, and another of savory, bind them into two or three small bundles, and put them to your carp, with four or five whole onions, twenty pickled oysters, and three anchovies. Then pour upon your carp as much claret wine as will only cover him, and season your claret well with salt, cloves, and mace, and the rinds of oranges and lemons : that done, cover your pot, and set it on a quick fire, till it be sufficiently boiled; then take out the carp, and lay it with the broth into the dish, and pour upon it a quarter of a pound of the best fresh butter, melted and beaten with half a dozen spoonfuls of the broth, the yolks of two or three eggs, and some of the herbs shred; garnish your dish with lemons, and so serve it up, and much good do you.-Dr. T.

* The haunts of river carp are, in the winter months, the broadest and most quiet parts of the river; but in summer they lie in deep loles, nooks, and reaches, near some scour, and under roots of trees, hollow banks, and, till they are near rotting, amongst or near great beds of weeds, flags, etc. Pond carp cannot, with propriety, be said to have any haunts; only it is to be noted, that they love a fat, rich soil, and never thrive in a cold, hungry water. They breed three or four times a year; but their first spawning-time is the beginning of May. Baits for the carp are all sorts of earth and dunghill worms, flag worms, grasshoppers (though not at top,) ox brains, the pith of an ox's backbone, green peas, and red or black cherries with the stones taken out. Fish with strong tackle, very near the bottom, and with a fine grass or gut next the hook, and use a goose-quill float. Never attempt to angle for a carp in a boat, for they will not come near it. It is said there are many carp in the Thames, westwarcl of Lundon, and that about February they retire to the creeks in that river; in some of which, many above two feet long have been taken with an angle. Carp live the longest out of the water of any fish. It is a common practice in Holland to keep them alive for three weeks or a month, by hanging them in a cool place, with wet moss, in a net, and feeding them with.bread and milk.-H. 
[REMARKS ON THE CARP.-Walton's natural history of the carp is marked by many singular errors, into which, as usual, he was led by such writers of naturalist romance as Gesner, Bacon, Dubravius, Aristotle, \&c. The old Angler's remarks on fishing for carp are very good, and may be followed without much deviation. I shall set his natural history right, and add to his instructions a few more on carp fishing. The Linnæan designation for this fine-looking fish is Cyprinus Carpis. Mr. Blaine, in his "Encyclopædia of Rural Sports," describes it very accurately thus:- "Yellowish olive carp, with wide dorsal fin, with the third ray serrated behind. It stands at the head of a numerous family, characterised by a small mouth, which is without teeth, their office being supplied by a bony apparatus within the throat, both above and below, which, acting against each other, comminate the food; the gill membrane is three-rayed, and there is one dorsal fin only. The common carp appears to be a native of the lakes, ponds, and some of the large rivers of the southern parts of Europe. The year 1514 is mentioned as the period when Leonard Mascal, a gentleman of Sussex, naturalized the tench amongst us; and although there is little reason to doubt that this gentleman did actually bring carp with him from the South, or import some, yet there is sufficient evidence from the 'Boke of St. Alban's' (the earliest work on angling"extant), published by Wynkyn de Worde, as early as 1496, that they were then known in England. The stately authoress, Juliana Barnes (Berners, or de Berners), calls it a 'daynteous fish,' although scarce. This being the case, the old distich (quoted by Walton in the first page of his chapter on the carp), 'Of carp, hops,' \&c., loses its metre and its point together." I think it is fairly proved that the carp is a fish exceedingly tenacious of life in water and out of it. In damp moss it can be kept many days alive. In its own element it may live to the age of one hundred years, but I do not think it often attains that age; and I am of opinion that it never exceeds it. Mr. Blaine, however, says,- "The age to which carp attain is very great, and several well-authenticated instances are adduced of its considerably exceeding a century, at least. Many of those which were introduced into the ponds at Versailles, etc., in the reign of Louis the Fourteenth (say 1690), are either still living, or at least were so a very short time before the French Revolution (of 1830). Dr. Smith, in his 'Tour to the Continent,' mentions them, and observes that they were grown white through age. Buffon assures us that he had seen, in the fosses of the Ponchartrain, carp which were known to be of the age of one hundred and fifty years." Carp in our rivers very rarely reach the weight of six pounds, and as seldom twelve pounds in our ponds. I have frequently seen at Mr. Grove's shop, in New Bond-street, carp of the weight of twenty pounds; and I think I once saw one that weighed twenty-eight pounds. But they were all Dutch fish. Mr. Blaine remarks, "The usual length of the carp in our country is from about twelve to fifteen or sixteen inches; but we have seen them here much longer, weighing twenty pounds. In warmer climates, they grow to twenty, thirty, or forty pounds." Walton says, the carp breeds several times in the year. I do not think so. Blaine sensibly explains the 
cause of the errors of those writers who assert that carp spawn half-adozen times during the warm months of the year. He says,- "The reproduction of earp has occasioned some dispute in later times: to our surprise, Mr. Daniel ('Rural Sports') says, 'they spawn several times in the year.' If at each time six hundred and twenty-one thousand are produced, which is the number of ova stated to have been counted in one roe, what then would be the annual produce?" Aristotle and Pliny, dealing in fable also, after the custom of their times, assert that they breed six times in the year, and the over-credulous Walton, influenced by their testimony, says, "carp and loaches are observed to breed several months in one year, which pikes and most other fish do not. And this is the rather to be believed, because you shall scarce, or never take a male carp without a melt, or a female without a roe, or spawn, and for the most part very much. We think it not improbable [It is not only probable, but the fact] that carp do not deposit the whole of their spawn at once; and, indeed, from some observations made by ourselves on a pond stored with carp only (where we could every day by a casting-net take as many as we pleased, and after subjecting them to examination, we could return them without injury), we have been led to suppose that these fish do not complete the spawning process at one time: on the contrary, we think it not improbable that they eject portions of ova only, at several distinct periods, and that some weeks even intervene between the first and last ejections." I assure the reader, that none of our river fish deposit their ova at a single sitting, no more than hens or other female birds do. The ova are not all mature at the same time. Those near the vent are the first matured and expelled. Examine the roe of any female fish, and you will find the ova of the lower part larger than those of the upper; more particularly so a short period before spawning time. The larger the collection of ova, the longer they require for ripening, and consequently, the longer the process of deposition lasts. A grilse or young salmon, in its second year, will deposit its ova in two or three days, because the quantity is small; whereas, a large, mature, female salmon, with several pounds of ova, cannot deposit the whole of it in less than a fortnight.

The carp is the wariest of all fresh-water fish, and none but the wariest angler can catch it of large size. A correspondent not long since wrote to me for advice. He said, he had a pond, in which were many large carp; and although he had angled for them in due season-from February to October-during seven years, he had not succeeded in capturing them. I advised him to line with hurdles the bank of the pond at the spots where he meant to fish-to ground-bait those spots with red worms, gentles, and especially with sweet paste, for three or four days - to then take his rod, and supporting it on a bifurcated prop (cut off the branch of a tree,) inserted in the bank behind the hurdles, to place on his line a hook broken off at the bend, that is, without barb or sharp point - to bait this harmless hook with sweet paste, and to sink it nearly to the bottom of the already ground-baited water. The carp will soon take this bait; and finding they can do so with impunity, they will become bolder hourly. Replacing the bait every time it is nibbled off, and continuing to do so for three or four days, commence then angling 
in earnest: with the same rod and line, but with a barbed hook, baited exactly as before, come behind the hurdle, and, with very light float, angle cautiously. My correspondent acted on my advice, and succeeded in catching as many of the large carp as he wanted. This method cannot be conveniently practised in rivers, unless in parts belonging to the angler. In river-fishing, red worms, gentles, grains, pastes, green peas, and cherries, are used as baits for carp. The foot-line should be of the best round fine gut, and the hook need not be larger than a No. 9 . Fish about a foot from the bottom. In fishing with paste, strike quickly but gently; in fishing with worms or gentles, do not strike until five or six seconds have elapsed after your perception of a bite. Prepared salmon-roe is an excellent bait for carp.

I shall here give a list of the best angling pastes, and show how they are made.

Simple paste for dace and roach is made by kneading torether, in clean hands, equal quantities of the pith of old and new bread. It must be kneaded until it is perfectly white and tcugh. To render it more adhesive round the hook in rough streams, work up with it a few fibres of raw cotton.

A coloured paste is made by washing flour in cold water, until the farinaceous particles disappear, and leave behind little more than simple gluten. Colour with vermilion to the hue of salmon-roe, and preserve it for use in balls immersed in water. When angling with it, keep it in a wet bag.

Sweet paste is an amalgamation of bread crumb and good white honey. Work it into an adhesive mass. Of this paste both Blaine and Salter say, "that it is a most killing bait for carp during the months of July and August, and indeed as long afterwards as the fishing-season lasts. As regards carp, this bait has a very peculiar claim on those anglers who cannot be at their posts early and late, where the carp-tisher ought to be in most cases: this paste obviates, in some measure, that necessity, as it is one of the few baits which carp will take in favourable weather, even at mid-day. Chub may be taken with it sometimes very well, and roach will seldom refuse it."

Prepared greaves is an excellent bait for barbel, and not a bad one for chub. It is prepared by saturating it in warm water, and working and washing it until it becomes tough and nearly white. A good paste may be made by moistening bread-crumb with the liquor in which the greaves have been softened, and then working the crumb into an adhesive mass. An admixture of a little raw cotton will be an improvement.

Cheese-paste, for chub and barbel, is made by working soft, palecoloured cheese and stale bread-crumb together. These last two pastes, with bullock's brains and spinal chord, are the best autumn and winter baits for barbel and chub.

Ground-baiting will greatly contribute to the success of the bottomfisher. When you fish with worms, ground-bait overnight with large clay balls, in the interior of which you have placed worms. Do not be sparing of them; and ever and anon, whilst you are fishing, clrop in one of these balls over your baited hook. When fishing with gentles, groundbait with clay balls filled with gentles. 
One of the best ground-baits for chub, carp, roach, and rlace, in still waters, is made by an admixture, kneaded to tolerable adhesiveness, of wet bread-pith, bran, and oatmeal. Small balls thrown in whilst you are angling for those fish, will attract them to the vicinity of your hook. You must angle with plain or sweet paste.

For rivers in which many sorts of coarse fish-barbel, chub, bream, \&c.-abound, the best general ground-bait is made by kneading together bran, meal, and clay, and dividing the mass into balls the size of the fist, and placing inside them-stuffing them as it were with-worms and gentles. They will make their way through the balls after the latter have been thrown into the water, and prove a great attraction to fish. Invariably place on your hooks better baits than those you ground-bait with.

Worms should be well seoured, cleansed, and rendered tough and lively, before they are used. To do this, put them in fiesh moss, freed from thorns and any hard substances, for a couple of days ; then examine them, and remove all sickly or dead ones. Place the others in a small depth of light pure mould, over which you must put a good portion of clean, fresh, moist moss. Add every third day a little cream or fresh milk, and you will keep the worms alive, healthy, wiry, and lively for several weeks ; examine them oceasionally, and eject invalids.

Gentles are best preserved, in summer, in moist sand; in winter, in layers of light mould, placed in a long, narrow wooden trough. The mould should be kept moist, or sunk about a foot beneath the earth.-ED.]

\section{CHAPTER $\mathrm{X}$.}

OBSERVATIONS ON THE BREAM; AND HOW TO CATCH HIM.

\section{[fourth 国aw.]}

Pisc. The Bream, being at a full growth, is a large and stately fish: he will breed both in rivers and ponds; but loves best to live in ponds, and where, if he likes the water, and air, he will grow not only to be very large, but as fat as a hog: he is by Gesner taken to be more pleasant or sweet than wholesome : this fish is long in growing, but breeds exceedingly in a water that pleases him; yea, in many ponds so fast as to overstore them, and starve the other fish.

He is very broad, with a forked tail, and his scales set in excellent order; he hath large eyes, and a narrow sucking mouth; he hath two sets of teeth, and a lozenge-like bone, a bone to help his grinding. The melter is observed to have two large melts; and the female, two large bags of eggs or spawn. 
Gesner reports, that in Poland a certain and a great number of large breams were put into a pond, which in the next following winter were frozen up into one entire ice, and not one drop of water remaining, nor one of these fish to be found, though they were diligently searched for; and yet the next spring, when the ice was thawed, and the weather warm, and fresh water got into the pond, he affirms they all appeared again. This Gesner affirms ; and I quote my author because it seems almost as incredible as the resurrection to an atheist : but it may win something, in point of believing it, to him that considers the breeding or renovation of the silk-worm, and of many insects. And that is considerable, which Sir Francis Bacon observes in his "History of Life and Death," fol. 20, that there be some herbs that die and spring every year, and some endure longer.

But though some do not, yet the French esteem this fish highly, and to that end have this proverb, " $\mathrm{He}$ that hath breams in his pond is able to bid his friend welcome." And it is noted, that the best part of a bream is his belly and head.*

Some say that breams and roaches will mix their eggs and melt together, and so there is in many places a bastard breed of breams, that never come to be either large or good, but very numerous.

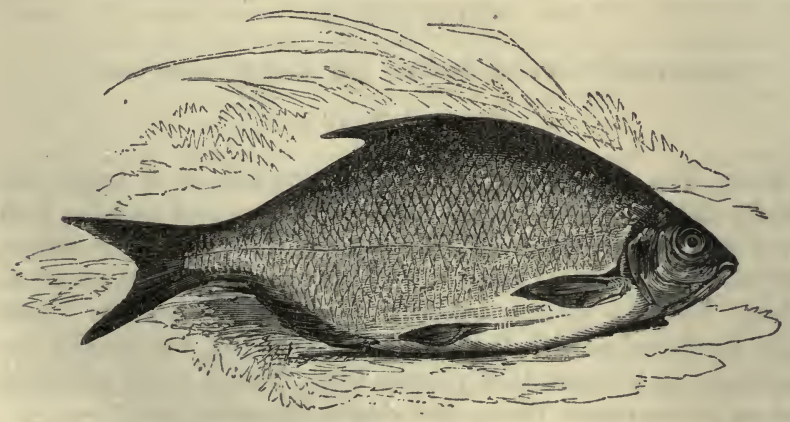

BREAM,

* The barbel and chub are bad edibles; but not so bad as the bream, which I consider the most tasteless of all river-fish. The largest bream are caught in the Oundle and the Ouse, in Huntingdonshire.-ED. 
The baits good to catch this Bream are many. 1. Paste made of brown bread and honey, gentles, or the brood of wasps that be young, and then not unlike gentles, and should be hardened in an oven, or dried on a tile before the fire, to make them tough; or there is at the root of docks or flags, or rushes in watery places, a worm not unlike a maggot, at which tench will bite freely. Or he will bite at a grasshopper with his legs nipped off, in June or July, or at several flies under water, which may be found on flags that grow near to the water-side. I doubt not but that there be many other baits that are good; but I will turn them all into this most excellent one, either for a carp or bream, in any river or mere : it was given to me by a most honest and excellent angler ; and hoping you will prove both, I will impart it to you.

1. Let your bait be as big a red worm as you can find, without a knot; get a pint or quart of them in an evening in garden walks, or chalky common, after a shower of rain, and put them with clean moss well washed and picked, and the water squeezed out of the moss as dry as you can, into an earthen pot or pipkin set dry, and change the moss fresh every three or four days, for three weeks or a month together ; then your bait will be at the best, for it will be clear and lively.

2. Having thus prepared your baits, get your tackling ready and fitted for this sport. Take three long angling rods, and as many and more silk, or silk and hair lines, and as many large swan or goose-quill floats. Then take a piece of lead, and fasten them to the low ends of your lines; then fasten your link-hook also to the lead, and let there be about a foot or ten inches between the lead and the hook; but be sure the lead be heavy enough to sink the float or quill a little under the water, and not the quill to bear up the lead, for the lead must lie on the ground. Note, that your link next the hook may be smaller than the rest of your line, if you dare adventure, for fear of taking the pike or pearch, who will assuredly visit your hooks, till they be taken out, as I will show you afterward, before either carp or bream will come near to bite. Note also, that when the worm is well baited, it will crawl up and down as far as the lead will give leave, which much enticeth the fish to bite without suspicion.

3. Having thus prepared your baits, and fitted your tack- 
ling, repair to the river, where you have seen them swim in skulls or shoals, in the summer time, in a hot afternoon, about three or four of the clock, and watch their going forth of their deep holes and returning, which you may well discern, for they return about four of the clock, most of them seeking food at the bottom, yet one or two will lie on the top of the water, rolling and tumbling themselves whilst the rest are under him at the bottom, and so you shall perceive him to keep sentinel; then mark where he plays most, and stays longest, which commonly is in the broadest and deepest place of the river, and there, or near thereabouts, at a clear bottom and a convenient landing-place, take one of your angles ready fitted as aforesaid, and scund the bottom, which should be about eight or ten feet deep, two yards from the bank is the best. Then consider with yourself whether that water will rise or fall by the next morning, by reason of any water-mills near, and according to your discretion take the depth of the place, where you mean after to cast your ground bait, and to fish, to half an inch, that the lead lying on near the groundbait, the top of the float may only appear upright half an inch above the water.

Thus you having found and fitted for the place and depth thereof, then go home and prepare your ground-bait, which is, next to the fruit of your labours, to be regarded.

\section{THE GROUND-BAIT.}

You shall take a peck, or a peck and a half, according to the greatness of the stream and deepness of the water where you mean to angle, of sweet gross-ground barley malt, and boil it in a kettle ; one or two warms is enough, then strain it through a bag into a tub, the liquor whereof hath often done my horse much good, and when the bag and malt is near cold, take it down to the water side about eight or nine of the clock in the evening, and not before ; cast in two parts of your ground-bait, squeezed hard between both your hands; it will sink presently to the bottom, and be sure it may rest in the very place where you mean to angle; if the stream run hard or move a little, cast your malt in handfuls a little the higher, upwards the stream. You may, between your hands, close the malt so fast in handfuls, that the water will hardly part it with the fall.

Your ground thus baited and tackling fitted, leave your bag 
with the rest of your tackling and ground-bait near the sporting-place all night, and in the morning about three or four of the clock, visit the water-side, but not too near, for they have a cunning watchman, and are watchful themselves too.

Then gently take one of your three rods, and bait your hook; casting it over your ground-bait, and gently and secretly draw it to you, till the lead rests about the middle of the ground-bait.

Then take a second rod, and cast in about a yard above, and your third a yard below the first rod; and stay the rods in the ground: but go yourself so far from the water-side, that you perceive nothing but the top of the floats, which you must watch most diligently. Then when you have a bite, you shall perceive the top of your float to sink suddenly into the water: yet, nevertheless, be not too hasty to run to your rods, until you see that the line goes clear away, then creep to the water-side, and give as much line as you possibly can : if it be a good carp or bream, they will go to the farther side of the river : then strike gently, and hold your rod at a bent, a little while; but if you both pull together, you are sure to lose your game, for either your line, or hook, or hold will break : and after you have overcome them, they will make noble sport, and are very shy to be landed. The carp is far stronger and more mettlesome than the bream.

Much more is to be observed in this kind of fish and fishing, but it is far better for experience and discourse than paper. Only, thus much is necessary for you to know, and to be mindful and careful of, that if the pike or pearch do breed in that river, they will be sure to bite first, and must first be taken. And for the most part they are very large ; and will repair to your ground-bait, not that they will eat of it, but will feed and sport themselves among the young fry that gather about and hover over the bait.

The way to discern the pike and to take him, if you mistrust your bream-hook,-for I have taken a pike a yard long several times at my bream-hooks, and sometimes he hath had the luck to share my line,-_may be thus :

Take a small bleak, or roach, or gudgeon, and bait it, and set it alive among your rods, two feet deep from the cork, with a little red worm on the point of the hook; then take a few crumbs of white bread, or some of the ground-bait, and sprinkle it gently amongst your rods. If Mr. Pike be there, 
then the little fish will skip out of the water at his appearance, but the live-set bait is sure to be taken.

Thus continue your sport from four in the morning till eight, and if it be a gloomy windy day, they will bite all day long. But this is too long to stand to your rods at one place, and it will spoil your evening sport that day, which is this :

About four of the clock in the afternoon, repair to your baited place ; and as soon as you come to the water-side, cast in one half of the rest of your ground-bait, and stand off : then whilst the fish are gathering together, for there they will most certainly come for their supper, you may take a pipe of tobacco ; and then in with your three rods, as in the inorning: you will find excellent sport that evening, till eight of the clock ; then cast in the residue of your ground-bait, and next morning by four of the clock visit them again for four hours, which is the best sport of all ; and after that, let them rest till you and your friends have a mind to more sport.

From St. James's-tide until Bartholomew-tide is the best; when they have had all the summer's food, they are the fattest.

Observelastly, that after three or four days' fishing together your game will be very shy and wary, and you shall hardly get above a bite or two at a baiting; then your only way is to desist from your sport about two or three days; and in the meantime, on the place you late baited, and again intend to bait, you shall take a tuft of green but short grass, as big or bigger than a round trencher ; to the top of this turf, on the green side, you shall with a needle and green thread, fasten one by one as many little red worms as will near cover all the turf; then take a round board or trencher, make a hole in the middle thereof, and through the turf, placed on the board or trencher, with a string or cord as long as is fitting, tied to a pole, let it down to the bottom of the water, for the fish to feed upon without disturbance about two or three days ; and after that you have drawn it away, you may fall to and enjoy your former recreation. $*$ B.A.

* The haunts of the bream, a fish which the angler seldom meets with, are the deepest and broadest parts of gentle, soft streams, with sandy, clayey bottoms : and the broadest and most quiet places of ponds, and where there are weeds. They spawn about the beginning of July; a little before which time they are best in season, though some think them best in September. The baits for the bream are red worms, small lob or marsh worms, gentles, and grasshoppers. In general they are to be fished for as carp.-H. 
[A Few Remarks ox the Breatr.-Walton has written more sensibly as a naturalist, and more artistically as an artist, on the bream, than on any other fish hitherto treated of by him. He seems to have a liking for this worthless fish ; thinks it not only handsome, but courageous and well-flavoured. It is neither; and very few modern anglers prize it either as an edible, or as a fish affording much sport. It is called by naturalists Cyprinus Brama. It is remarkable for the smallness of its dorsal fin, and the largeness of its anal one-there being no fewer than twenty-seven rays in the latter. Its tail is exceedingly forked, and it has a forked, rather large fin between the dorsal fin and tail. It is exceedingly hog-backed, and very deep and thin in the body. It has a rery small head, and very prominent eyes. It affects deep, still waters, with soft half muddy, half clayey bottoms. It is in good season in spring, and worms then are the best baits for it. Daniel points out two good modes of fishing with them. The first is, "after plumbing the depth, put one or more shot a foot below the float, to balance it, which is a way to take the shyest fish; the bait a large red worm, which must be laid in, and let sink very gradually to the ground-bait. When the fish bites, strike gently that very instant." 'The second method is, employing " the running line, with a bullet and hole through it, and a small shot to hinder the bullet falling on the hook; let this run on the bottom with the current into holes, and equally as for bream it will be found to answer for all other fish that bite at the bottom." The last species of tackle corresponds with the modern ledger-line, of which I shall have to speak fully when I come to Chap. XIV., which treats of the barbel. An extract from Blaine, accompanied by an original sentence or two, will complete the measure of information required to enable any one to angle successfully for the bream. That elaborate and able sporting writer says, "Bream will likewise take caddis-bobs and grubs, and all other usual larvæ. In the large rivers of the midland counties, as well as in the great pieces of water called broads, meres, fleets, \&c., the salmon-roe is an excellent summer bait, and will be seldom refused by bream : they will likewise take natural flies; as the house-fly, flesh-fly, stone-fly, during the day; and in the evening they seldom refuse the various moths. In dipping with these baits, the utmost possible caution must be observed by the angler to keep himself concealed; for the moment bream discover any one near, they sink to the bottom immediately; though, as they very soon appear again, the mischief may usually be repaired . . . . . The bream is not always a quick biter, and when it is, its small mouth sometimes produces a kind of suction, particularly if the bait be a full-sized one: it is, therefore, necessary to strike with some caution, and the proper degree of it will be taught by a few successful, and a few unsuccessful bites." I have frequently caught bream with the artificial fly. They will take brown palmers, the fly called " the governor," and in the evening yellow and white artificial moths.-ED.] 


\section{CHAPTER XI.}

\section{OBSERVATIONS ON THE TENCH; AND ADVICE HOW TO ANGLE} FOR HIM.

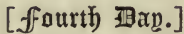

PIsc. The Tench, the physician of fishes, is observed to love ponds better than rivers, and to love pits better than either : yet Camden observes, there is a river in Dorsetshire that abounds with tenches, but doubtless they retire to the most deep and quiet places in it.

This fish hath very large fins, very small and smooth scales, a red circle about his eyes, which are big and of a gold colour, and from either angle of his mouth there hangs down a little barb. In every tench's head there are two little stones which foreign physicians make great use of, but he is not commended for wholesome meat, though there be very much use made of them for outwardapplications. Rondeletius says, that at his being at Rome, he saw a great cure done by applying a tench to the feet of a very sick man. This, he says, was done after an unusual manner, by certain Jews. And it is observed, that many of those people have many secrets yet unknown to Christians ; secrets that have never yet been written, but have been (since the days of their Solomon, who knew the nature of all things, even from the cedar to the shrub) delivered by tradition, from the father to the son, and so from generation to generation, without writing ; or (unless it were casually), without the least communicating them to any other nation or tribe; for to do that they account a profanation. And yet it is thought that they, or some spirit worse than they, first told us that lice swallowed alive, were a certain cure for the yellowjaundice. This, and many other medicines, were discovered by them, or by revelation ; for, doubtless, we attained them not by study.

Well, this fish, besides his eating, is very useful both dead and alive for the good of mankind. But I will meddle no more with that; my honest humble art teaches no such boldness ; there are too many foolish meddlers in physic and divinity, that think themselves fit to meddle with hidden secrets, and so bring destruction to their followers. But I'll 
not meddle with them, any farther than to wish them wiser; and shall tell you next, for I hope I may be so bold, that: the tench is the physician of fishes, for the pike especially ; and that the pike, being either sick or hurt, is cured by the touch of the Tench. And it is observed, that the tyrant pike will not be a wolf to his physician, but forbears to. devour him though he be never so hungry.

This fish, that carries a natural balsam in him to cure

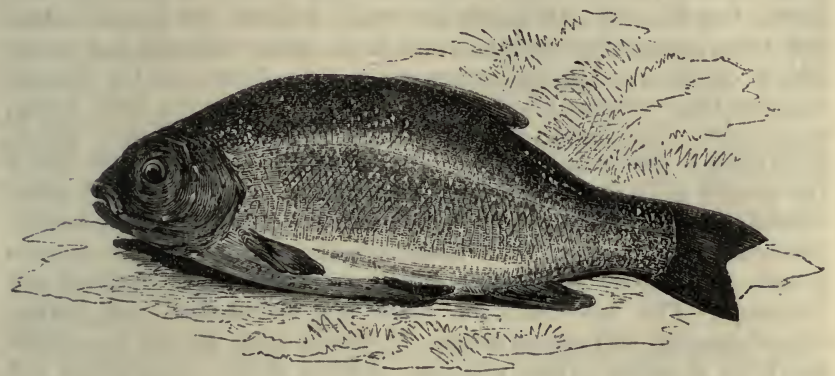

himself and others, loves yet to feed in very foul water, and amongst weeds. And yet I am sure he eats pleasantly, and doubtless, you will think so too, if you taste him. And I shall therefore proceed to give you some few, and but a few, directions how to catch this Tench, of which $I$ have given you these observations.

He will bite a paste made of brown bread and honey, or at a marsh-worm, or a lob-worm; he inclines very much to any paste with which tar is mixed : and he will bite also at a smaller worm, with his head nipped off, and a cod-worm put on the hook before that worm; and I doubt not but that he will also in the three hot months,-for in the nine colder he stirs not much,-bite at a flag worm, or at a green gentle; but I can positively say no more of the tench,* he being a

* The haunts of the tench are nearly the same with those of the carp. Theydelight more in ponds than in rivers; and lie under weeds, near sluices, and. at pond-heads. They spawn about the beginning of July; and are best in season from the beginuing of September to the end of May. They /will bite all the hot months; but are taken best in April and May. There are no better baits for this fish than a middle-sized lob-worm, or red-worm, well scoured; a gentle; a young wasp grub, boiled; or a green worm shook from 


\section{fish I.have not often angled for ; but I wish my honest scholar may, and be ever fortunate when he fishes.}

[Observations ox the Tench.-Waiton thinks unfavourably of this fish as a table delicacy. It makes, however, a far better dish than either chub, bream or barbel. Its medicinal properties I do not believe in, and I am convinced that application of its slimy exterior to either fish or flesh wounds will not heal them. If the voracious pike spares it, and I very much doubt whether he does, 'tis not out of gratitude for cures performed. Some instinct not to be accounted for prevents the pike from making of the tench a favourite prey. It is a pond-fish, and thrives best in water with muddy and weedy bottoms. It spawns in May and June, amongst the roots and subaqueous stems of plants, and is very soon in condition. Linnæus names it Cyprinus Tinca, and Dr. Fleming describes this "mucous bluish olive carp" as having "the back, dorsal, and ventral fins, dusky; the head, sides, and belly, yellowish green; body thick in proportion to its length; a minute beard on each side of the mouth; gape ascending; dorsal fin, eleven rays; pectoral, seventeen; ventral, nine; and anal, ten rays. The tail of the tench is not forked, but squared. It grows to a large size, frequently to eight or nine pounds, particularly in the sluggish rivers and ponds of Holland and Germany. The best baits for tench are middle-sized red worms, brandlings, flag, and marsh worms. I should never fish for them with any kind of paste. They will take gentles, caddies, wasp-grubs, and caterpillars. You must fish for them quite close to the bottom. They bite best after gentle warm rains, and in summer while the rain is actually falling. At this season, they are found among weed-beds, and by the sides of them. Captain Willianson, in his "Vade-Mecum," very properly remarks, "Tench do not swallow a bait very quickly, sometimes holding it in their mouths for a while; therefore give them good time, and let them either keep the float down, or, as is often the case, let them rise with the bait, so as to lay your float on the water. This is an excellent sign, and warrants your striking, but rather gently, lest the fish be only sucking the bait, for he will seldom return after it is drawn from his mouth. Your tench-rod should be strong, winch-line stout, and foot-line of the best, round, but fine gut. Use number eight and nine hooks; in deep running waters smallish cork floats, but in still deeps and ponds quill floats. If the bottom of the water be muddy, fish an inch or two from it; if it be sandy or gravelly, let your bait touch it.-ED.]

the boughs of trees. Use a strong grass, or gut ; and a goose-quill float without a cork, except in rivers, where the cork is always to be preferred. Fish very near the ground. And if you bait with gentles, throw in a few at the taking every fish, which will dray them to your hook, and keep them together. -H. 


\title{
CHAPTER XII.
}

\begin{abstract}
OBSERVATIONS ON THE PEARCH ; AND DIRECTIONS HOW TO FISH FOR HIM.
\end{abstract}

\section{[ffourtij 细an.]}

PIsc. The Pearch is a very good and a very bold biting fish. He is one of the fishes of prey that, like the pike and trout, carries his teeth in his mouth, which is very large; and he dare venture to kill and devour several other kinds of fish. He has a hooked or hog back, which is armed with sharp and stiff bristles, and all his skin armed or covered over with thick dry hard scales, and hath, which few other fish have, two fins on his back. He is so bold that he will invade one of his own kind, which the pike will not do willingly, and you may therefore easily believe him to be a bold biter.

The pearch is of great esteem in Italy, saith Aldrovandus, and especially the least are there esteemed a dainty dish. And Gesner prefers the pearch and pike above the trout, or any fresh-water fish : he says the Germans have this proverb, "More wholesome than a pearch of Rhine;" and he says the river pearch is so wholesome that physicians allow him to be eaten by wounded men, or by men in fevers, or by women in childbed.

He spawns but once a year, and is, by physicians, held very nutritive ; yet, by many, to be hard of digestion. They abound more in the river Po, and in England, says Rondeletius, than other parts, and have in their brain a stone which is in foreign parts sold by apothecaries, being there noted to be very medicinable against the stone in the reins. These be a part of the commendations which some philosophical brains have bestowed upon the fresh-water pearch ; yet they commend the sea-pearch, which is known by having but one fin on his back,-of which, they say, we English see but a few, - to be a much better fish.

The pearch grows slowly, yet will grow, as I have been credibly informed, to be almost two feet long ; for an honest informer told me such a one was not long since taken by Sir Abraham Williams, a gentleman of worth, and a brother 
of the angle, that yet lives, and I wish he may: this was a deep bodied fish, and doubtless durst have devoured a pike of half his own length ; for I have told you he is a bold fish, such a one as, but for extreme hunger, the pike will not devour ; for to affright the pike, and save himself, the pearch will set up his fins, much like as a turkey-cock will sometimes set up his tail.

But, my scholar, the pearch is not only valiant to defend himself, but he is, as I said, a bold-biting fish, yet he will not bite at all seasons of the year; he is very abstemious in winter, yet will bite then in the midst of the day, if it be warm : and note, that all fish bite best about the midst of a warm day in winter, and he hath been observed by some not usually to bite till the mulberry-tree buds, that is to say, till extreme frosts be past the spring, for when the mulberry-tree blossoms many gardeners observe their forward fruit to be past the danger of frosts, and some have made the like observation on the pearch's biting.

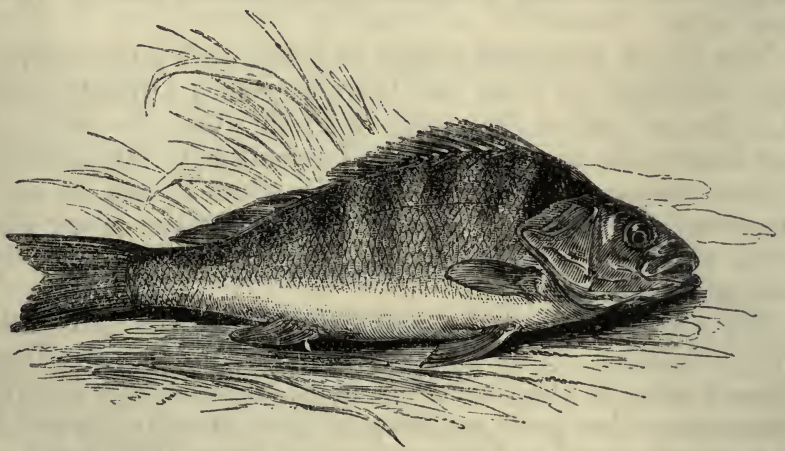

But bite the pearch will, and that very boldly : and as one has wittily observed, if there be twenty or forty in a hole, they may be at one standing all catched one after another, they being, as he says, like the wicked of the world, not afraid, though their fellows and companions perish in their sight. And you may observe, that they are not like the solitary pike, but love to accompany one another, and march together in troops.

And the baits for this bold fish are not many: I mean, he will bite as well at some or at any of these three, as at any 
or all others whatsoever, a worm, a minnow, or a little frog, of which you may find many in hay-time ; and of worms, the dunghill-worm, called a brandling, I take to be best, being well scoured in moss or fennel; or he will bite at a worm that lies under cow-dung, with a bluish head. And if you rove for a pearch with a minnow, then it is best to be alive, you sticking your hook through his back fin, or a minnow with the hook in his upper lip, and letting him swim up and down about mid-water, or a little lower, and you still keeping him to about that depth by a cork, which ought not to be a very little one; and the like way you are to fish for the pearch, with a small frog, your hook being fastened through the skin of his leg, towards the upper part of it; and lastly, I will give you but this advice, that you give the pearch time enough when he bites, for there was scarce ever any angler that has given him too much. And now I think best to rest myself, for I have almost spent my spirits with talking so long.

VEx. Nay, good master, one fish more, for you see it rains still, and you know our angles are like money put to usury, they may thrive, though we sit still, and do nothing but talk and enjoy one another. Come, come, the other fish, good master.

Prsc. But scholar, have you nothing to mix with this discourse, which now grows both tedious and tiresome? Shall I have nothing from you, that seem to have both a good memory, and a cheerful spirit?

Ver. Yes, master, I will speak you a copy of verses that were made by Doctor Donne, and made to show the world that he could make soft and smooth verses when he thought smoothness worth his labour; and I love them the better because they allude to rivers, and fish and fishing. They be these :-

Come live with me, and be my love, And we will some new pleasures prove, Of golden sands and crystal brooks, With silken lines and silver hooks.

There will the river whisp'ring run, Warm'd by thy eyes more than the sun; And there th' enamell'd fish will stay, Begging themselves they may luetray.

When thou wilt swim in that live bath, Each fish, which every channel hath, Most amorously to thee will swim, Gladder to catch thee, than thou him. 
If thou to be so seen be'st loath, By sun or moon, thou darkenest both; And if mine eyes have leave to see, I need not their light, having thee.

Let others freeze with angling-reeds, And cut their legs with shells and weeds, Or treacherously ponr fish beset, With strangling snares, or windowy net:

Let coarse bold hands, from slimy nest, The bedded fish in banks outwrest; Let curious traitors sleave silk flies, To witch poor wandering fishes' eyes :

For thee thou need'st no such deceit, For thou thyself art thine own bait : That fish that is not catch'd thereby Is wiser far, alas! than I.

Pisc. Well remembered, honest scholar; I thank you for these choice verses, which I have heard formerly, but had quite forgot, till they were recovered by your happy memory. Well, being I have now rested myself a little, I will make you some requital, by telling you some observations of the eel, for it rains still, and because, as you say, our angles are

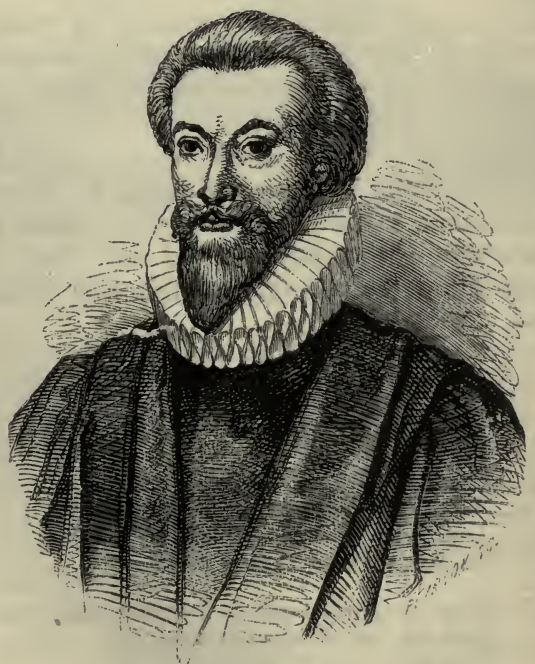

DR. DONNE. 
as money put to use, that thrives when we play, therefore we'll sit still and enjoy ourselves a little longer under this honeysuckłe hedge.*

[A few words about the Perch.-The good old father of us allIzaak of venerated memory - hath well and truly written in the preceding chapter of the perch. I wish he had left out the fourth paragraph about Sir Abraham Williams' perch, "almost two foot long." No perch ever attained that length in this country, and there is not one angler in five thousand that ever saw an English perch twelve inches long. Pennant speaks of one weighing nine pound caught in the Serpentine; and in an obscure angling book, mention is made of one eaught near Oxford, of the alleged length of twenty-nine inches. Such giants have disappeared from the depths of our waters long ago. I have seen pond-fed perch of four and five pounds in weight, but for one perch caught by me, or others of my acquaintance, of two pounds weight, I have seen hundreds of less than ten ounces. I like the fish much. He is a daring fellow, of burly beauty; no dainty epicure, though epicures consider him when dished a dainty, and is satisfied with a plentiful repast, in fresh water, of worms and small fish; and in tideways, or brackish water, with a meal of fresh shrimps. Give him three dishes, and he will not ask you for entremets or hors d'cuvres. His Latin name is Perca fluviatilis, and Fleming thus describes him:First dorsal fin longer than the second; length about a foot; back arched greenish black; sides with fine transverse black bands; belly reddish white; ventral, anal, and caudal fins red; irides golden. Each dorsal fin has fourteen rays; the pectoral twelve. I am a great admirer of Thames pereh. They are beautifully coloured, and they are less roundshouldered than those of other waters. The first dorsal-fin of the perch is very large, bristling with strong, pointed spines, which are to him a

* Although perch, like trout, delight in clear swift rivers, with pebbly, gravelly bottoms, they are often found in sandy, clayey soils; they love a moderately deep water, and frequent loles by the sides of or near little streams, and the hollows under banks. The perch spawns about the beginning of March : the best time of the year to angle for him is from the beginning of May till the end of June, yet you may continue to fish for him till the end of September; he is best taken in cloudy, windy weather, and, as some say, from seven to ten in the forenoon, and from two to seven in the afternoon. Other baits for the perch are loaches, miller's thumbs, stickle-backs, small-lob, and marsh, and red-worms, well scoured; horse-beans, boiled ; cad-bait, oak-worms, bobs, and gentles. Many of these fish are taken in the rivers about Oxford; and the author of the "Angler's Sure Guide," says, he once saw the figure of a perch, drawn with a pencil on the door of a house near that city, which was twenty-nine inches long; and was informed it was the true dimensions of a living perch ("Angler's Sure Guide," p. 155). The largest perch are taken with a minnow, hooked with a good hold through the upper lip; for the perch, by reason of the figure of his mouth, cannot take the bait crosswise, as the pike will. When you fish thus, use a large cork float, and lead your line about nine inches from the bottom, otherwise the minnow will come to the top of the water; but in the ordinary way of fishing, let your bait hang within about six inches of the ground.-H. 
good defensive armour. It saves him from the attacks of pike and other enemies. Fish of prey are generally solitary. The perch is a remarkable exception, for although fiercely predatory, he is very socially gregarious. The lion hunts alone, so does the pike; the wolf hunts in packs, the perch in shoals. The largest perch are caught by sinking and roving with a live minnow or gudgeon, or by spinning with a dead one. I have taken them well by spinning with Flinn's flexible fishbaits, and sometimes I have caught them with large, gaudy artificial flies. There is no better way of fishing for perch than with the paternoster line-a gear consisting of three hooks, whipped on strong threeinch lengths of gut, or hog's bristles, projecting twelve or fifteen inches apart from a very stout salmon-gut foot-line. On the hook nearest the bottom I would put a worm; on the one next to that a live minnow, or middle-sized gudgeon: and on the uppermost hook a fresh shrimp, small frog, a gentle, caddis, wasp-grub, or caterpillar. At the extreme end of the foot-line, a perforated bullet should be attached. By its means your bait will be kept down, and will move slowly, or otherwise, according to the flow of the water. Strike rather sharply as soon as you feel a bite. Fish for perch from February to November, in deep gravelly streams, by the sides of the buttresses of bridges, piles, eamp-sheds, in eddies, below weirs, and in back waters, in docks, near sluices, and in deep holes in the middle of strong currents. In a "Handbook of Angling," I write,- “ If you faney pereh-poaching, get a very large, wide-mouthed glass bottle, and half fill it with pure water, into which put a dozen of bright, lively minnows; give them air by inserting the barrel of a quill, open at each end, through the bung of the bottle, which sink in a pond, or the whereabouts of pereh in a river. The bottled minnows will attract perch to them. In about twenty-four hours or more after you have sunk your decoy, come with a paternoster-line, baited with lire minnows or small gudgeons, and you cannot but catch several of the assembled and prowling perch." In the spring months, fish for pereh from seven to ten, a.m., and from two o'clock, p.m., to dusk. In summer, from sunrise to nine a.m., and in the afternoon, from four to sunset.-ED.]

\section{CHAPTER XIII.}

OBSERVATIONS OF THE EEL, AND OTHER FISH THAT WANT SCALES;

AND HOW TO FISH FOR THEM.

\section{[.fFourth 进an.]}

Pisc. It is agreed by most men, that the eel is a most dainty fish; the Romans have esteemed her the Helena of their feasts, and some the queen of palate-pleasure. But 
most men differ about their breeding: some say they breed by generation as other fish do, and others, that they breed, as some worms do, of mud; as rats and mice, and many other living creatures are bred in Egypt, by the sun's heat, when it shines upon the overflowing of the river Nilus; or out of the putrefaction of the earth, and divers other ways. Those that deny them to breed by generation as other fish do, ask, if any man ever saw an eel to have a spawn or melt? and they are answered, that they may be as certain of their breeding as if they had seen spawn : for they say, that they are certain that eels have all parts, fit for generation, like other fish,* but so small as not to be easily discerned, by reason of their fatness ; but that discerned they may be ; and that the he and the she-eel may be distinguished by their fins. And Rondeletius says he has seen eels cling together like dew-worms.

And others say, that eels, growing old, breed other eels out of the corruption of their own age ; which, Sir Francis Bacon says, exceeds not ten years. And others say, that as worms are made of glutinous dew-drops, which are condensed by the sun's heat in those countries, so eels are bred of a particular dew, falling in the months of May or June on the banks of some particular ponds or rivers, apted by nature for that end ; which in a few days are, by the sun's heat, turned into eels ; and some of the ancients have called the eels that are thus bred the offspring of Jove. I have seen, in the beginning of July, in a river not far from Canterbury, some parts of it covered over with young eels, about the thickness of a straw ; and these eels did lie on the top of that water, as thick as motes are said to be in the sun; and I have heard the like of other rivers, as namely, in Severn, where they are

* That fishes are furnished with parts fit for generation cannot be doubted, since it is a common practice to castrate them. See the method of doing it in "Philos. Trans." vol. xlviii. part. ii., for the year 1754, page 870.-H.

[I am surprised at the anatomical ignorance of Sir J. Hawkins, and at that of the writer in the "Philosophical Transactions." No river-fish have external organs of generation, and cannot therefore be castrated. Eels have ova and milt like other fresh-water fish, but in minute portions. They are migratory in rivers running into the sea. They migrate to deposit their spawn in salt-water, and immigrate to fresh-water to grow in it. The salmon migrates to sea for a different purpose-to grow and fatten in salt-water; and immigrates to fresh to procreate its species in the shallows. I am of opinion that eels are oviparous, and I know, of my own knowledge, that Mr. Andrew Young, of Invershin, Sutherlandshire, has bred them artifically from impregnated spawn, procured from living male and female specimens.-ED.] 
called yelvers; and in a pond, or mere, near unto Staffordshire,' where, about a set time in summer, such small eels abound so much that many of the poorer sort of people that inhabit near to it, take such eels out of this mere with sieves or sheets; and make a kind of eel-cake of them, and eat it like as bread. And Gesner quotes venerable Bede,* to say, that in England there is an island called Ely, by reason of the innumerable number of eels that breed in it. But that eels may be bred as some worms, and some kind of bees and wasps are, either of dew, or out of the corruption of the earth, seems to be made probable by the barnacles and young goslings bred by the sun's heat and the rotten planks of an old ship, and hatched of trees; both which are related for truths by $\mathrm{Du}$ Bartas and Lobel, $\uparrow$ and also by our learned Camden, and laborious Gerard, $\ddagger$ in his Herbal.

It is said by Rondeletius, that those eels that are bred in rivers that relate to or be near to the sea, never return to the fresh waters (as the salmon does always desire to do), when they have once tasted the salt water; and I do the more easily believe this, because I am certain that powdered beef is a most excellent bait to catch an eel. And though Sir Francis Bacon will allow the eel's life to be but ten years, yet he, in his History of Life and Death, mentions a lamprey belonging to the Roman emperor, to be made tame, and so kept for almost threescore years ; and that such useful and pleasant observations were mäde of this lamprey, that Crassus the orator, who kept her, lamented her death. And we read in Dr. Hakewill, that Hortensius was seen to weep at the death of a lamprey that he had kept long and loved exceedingly.\$

* The most universal scholar of his time: he was born at Durham about 671, and bred under St. John of Beverley. He was a man of great virtue, and remarkable for a most sweet and engaging disposition: he died 734, and lies buried at Durham.

† Matthias de Lobel, or L'Obel, an eminent physician and botanist of the sixteenth century, was a native of Lisle, in Flanders. He was a disciple of Rondeletius, and, being invited to London by King James the First, published there his " Historia Plantarum," and died in the year 1616. He was the author of several books connected with medico-botany.

¥ The perzon here mentioned is John Gerard, the first of our English botanists: he was by profession a surgeon ; and published, in 1597, a "Herbal," in a large folio, dedicated to the lord treasurer Burleigh; and, two years after, a "Catalogue of Plants, Herbs," \&c., to the number of eleven hundred, raised and naturalised by himself in a large garden near his house in Holborn. The latter is dedicated to Sir Walter Raleigh.

\$ The author, vol. i. p. 212, has cited from Pliny an instance of the fondness 
It is granted by all, or most men, that eels, for about six months, that is to say, the six cold months of the year, stir not up and down, neither in the rivers, nor in the pools in which they usually are, but get into the soft earth or mud; and there many of them together bed themselves, and live without feeding upon anything, as I have told you some swallows have been observed to do in hollow trees, for those cold six months ; and this the eel and swallow. do, as not being able to endure winter weather: for Gesner quotes Albertus to say, that in the year 1125 , that year's winter being more cold than usually, eels did by nature's instinct get out of the water into is stack of hay in a meadow upon dry ground, and there bedded themselves, but yet at last a frost killed them. And our Camden relates, that in Lancashire fishes were digged out of the earth with spades, where no water was near to the place. I shall say little more of the eel, but that, as it is observed, he is impatient of cold ; so it hath been observed, that in warm weather an eel has been known to live five days out of the water.

And lastly, let me tell you that some curious searchers into the natures of fish observe, that there be several sorts or kinds of eels, as the silver eel, and green or greenish eel, with which the river of Thames abounds, and those are called grigs ; and a blackish eel, whose head is more flat and bigger than ordinary eels; and also an eel whose fins are reddish, and but seldom taken in this nation, and yet taken sometimes: these several kinds of eels are, say some, diversely bred; as namely, out of the corruption of the earth, and some by dew, and other ways, as I have said to you : and yet it is affirmed by some for certain, that the silver eel is bred by generation, but not by spawning as other fish do, but that her brood come alive from her, being then little live eels, no bigger nor longer than a pin : and I have had too many testimonies of this to doubt the truth of it myself; and if I thought it needful I might prove it, but I think it is needless.

And this eel, of which I have said so much to you, may

of Antonia, a woman, for a tame lamprey, which the tenderness of her sex might perhaps excuse; but the sagacity and docility of these creatures seem. less wonderful than the weakness of such men as Crassus and Hortensius, in becoming mourners for the death of an eel. The former of these two persons was, for this his pusillanimity, reproached in the senate of Rome by Domitius, in these words: "Foolish Crassus! you wept for your muræna" (or lamprey). "That is more," retorted Crassus, "than you did for your two wives." (Lord Bacon's " Apophthegms.")-H. 
be caught with divers kinds of baits; as namely, with powdered beef, with a lob or garden-worm, with a minnow, or gut of a hen, chicken, or the guts of any fish, or with almost anything, for he is a greedy fish :* but the eel may be caught especially with a little, a very little lamprey, which some call a pride, and may in the hot months be found many of them in the river Thames, and in many mud-heaps in other rivers, yea, almost as usually as one finds worms in a dunghill.

Next note, that the eel seldom stirs in the day, but then hides himself ; and therefore he is usually caught by night, with one of these baits of which I have spoken : and may be then caught by laying hooks, which you are to fasten to the bank, or twigs of a tree ; or by throwing a string across the stream with many hooks at it, and those baited with the aforesaid baits, and a clod, or plummet, or stone, thrown into the river with this line, that so you may in the morning find it near to some fixed place; and then take it up with a draghook, or otherwise. But these things are, indeed, too common to be spoken of ; and an hour's fishing with an angler will teach you better, both for these and many other common things in the practical part of angling, than a week's discourse. I shall therefore conclude this direction for taking the eel, by telling you, that in a warm day in summer I have taken many a good eel by sniggling, and have been much pleased with that sport.

And because you, that are but a young angler, know not what sniggling is, I will now teach it to you. You remember I told you, that eels do not usually stir in the day time; for then they hide themselves under some covert; or under boards or planks about flood-gates or weirs or mills ; or in holes on the river banks: so that you, observing your time in a warm day, when the water is lowest, may take a strong

* To this truth I myself can bear witness. When I dwelt at Twickenham, a large canal adjoined to my house, which I stocked with fish. I had from time to time broods of ducks, which, with their young ones, took to the water. One dry summer, when the canal was very low, we missed many young ducks, but could not find out how they went. Resolving to take advantage of the lowness of the water to clean the canal, a work which had not been done for thirty years before, $I$ drained and emptied it, and found in the mud a great number of large eels. Some of them I reserved for the use of my family ; which being opened by the cook surprised us all; for in the stomachs of several of them were found, undigested, the necks and heads of young ducks, which, doubtless, were those of the ducks we had missed.-H. 
small hook, tied to a strong line, or to a string about a yard long: and then into one of these holes or between any boards about a mill or under any great stone or plank or any place where you think an eel may hide or shelter herself, you may, with the help of a short stick, put in your bait, but leisurely, and as far as you may conveniently; and it is scarce to be doubted, but if there be an eel, within the sight of it, the eel will bite instantly, and as certainly gorge it ; and you need not doubt to have him if you pull him not out of the hole too quickly, but pull him out by degrees; for he, laying folded double in his hole, will, with the help of his tail, break all, unless you give him time to be wearied with pulling : and so get him out by degrees, not pulling too hard.

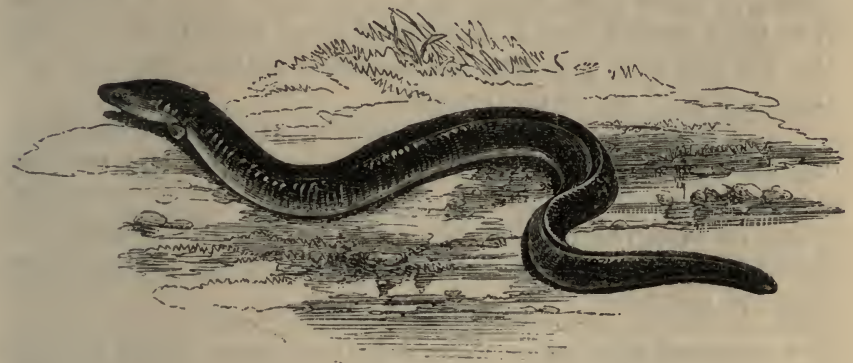

TEB ERL.

And to commute for your patient hearing this long direction, I shall next tell you how to make this EEL a most excellent dish of meat.

First, wash him in water and salt, then pull off his skin below his vent or navel, and not much further; having done that, take out his guts as clean as you can, but wash him not: then give him three or four scotches with a knife, and then put into his belly and those scotches, sweet herbs, and anchovy, and a little nutmeg grated, or cut very small; and your herbs and anchovies must also be cut very small, and mixed with good butter and salt : having done this, then pull his skin over him all but his head, which you are to cut off, to the end you may tie his skin about that part where his head grew; and it must be so tied as to keep all his moisture within his 
skin : and having done this, tie him with tape or packthread to a spit, and roast him leisurely, and baste him with water and salt till his skin breaks, and then with butter ; and having roasted him enough, let what was put into his belly and what he drips, be his sauce.-S. F.

When I go to dress an eel thus, I wish he were as long and big as that which was caught in Peterborough river in the year 1667, which was a yard and three-quarters long. If you will not believe me, then go and see at one of the coffeehouses in King-street, in Westminster.

But now let me tell you, that though the eel thus dressed be not only excellent good, but more harmless than any other way; yet it is certain, that physicians account the eel dangerous meat : I will advise you, therefore, as Solomon says of honey, "Hast thou found it, eat no more than is sufficient, lest thou surfeit; for it is not good to eat much honey." And let me add this, that the uncharitable Italian bids us "give eels and no wine to our enemies."

And I will beg a little more of your attention to tell you, Aldrovandus, and divers physicians, commend the eel very much for medicine, though not for meat. But let me tell you one observation, that the eel is never out of season; as trouts, and most other fish are at set times : at least most eels are not.*

* The haunts of the eel are, weeds, under roots, stumps of trees, holes, and clefts of the earth, both in the banks and at the bottom, and in the plain mud, where they lie with only their heads out, watching for prey. They are also found under great stones, old timber, about flood-gates, weirs, bridges, and old mills. They delight in still waters, and in those that are foul and muddy; though the smaller eels are to be met with in all sorts of rivers and soils. Although the manner in which eels, and indeed all fish, are generated, is sufficiently settled, as appears by the foregoing notes; there yet remains a question undecided by naturalists; and that is, Whether the eel be an oviparous or a viviparous fish? Walton inclines to the latter opinion. The following relation from Bowlker may go near to determine the question: "Being acquainted with an elderly woman, who had been wife to a miller near fifty years, and much employed in dressing of eels, I asked her if she had ever found any spawn. or eggs in those eels she opened? She said she had never observed any; but that she had sometimes found living eels in them, about the bigness of a small needle; and particularly, that she once took out ten or twelve, and put them upon the table, and found them to be alive; which was confirmed to me by the rest of the family. The time of the year when this happened was, as they informed me, about a fortnight or three weeks after Michaelmas; which makes me of opinion that they go down to the sea, or salt-water, to prepare themselves for the work of propagating and producing their young. To this I must add another observation of the same nature, that was made by a gentleman of fortune not far from Ludlow, and in the commission of the peace for the county of Salop; who going to visit a gentleman, his friend, was shown a very fine large eel that was going to be dressed, about whose sides and belly he observed 
I might here speak of many other fish, whose shape and nature are much like the eel, and frequent both the sea and fresh rivers; as namely, the lamprel, the lamprey, and the lamperne: as also of the mighty conger, taken often in Severn, about Gloucester : and might also tell in what high esteem many of them are for the curiosity of their taste. But these are not so proper to be talked of by me, because they make us anglers no sport; therefore I will let them alone, as the Jews do, to whom they are forbidden by their law.

And, scholar, there is also a Flounder, a sea-fish which will wander very far into fresh rivers, and there lose himself and dwell : and thrive to a hand's breadth, and almost twice so long: a fish without scales, and most excellent meat: and a fish that affords much sport to the angler, with any small worm, but especially a little bluish worm gotten out of marshground or meadows, which should be well scoured.* But

a parcel of little creeping things, which at first made him suspect it had been kept too long; but upon nearer inspection, they were found to be perfect little eels, or elvers. Upon this it was immediately opened in the sight of several other gentlemen, and, in the belly of it, they found a lump about as big as a nutmeg, consisting of an infinite number of those little creatures, closely wrapped. up together; which, being put into a bason of water, soon separated, and swam about the bason. This he has often told to several gentlemen of credit in his neighbourhood, from some of whom I first received this account : but I have lately had the satisfaction of having it from his own mouth, and therefore $I$ think this may serve to put the matter out of all doubt, and may be sufficient to prove that eels are of the viviparous kind." Taking it for granted then that eels do not spawn, all we have to say in this place is, that though, as our author tells us, they are never out of season, yet, as some say, they are best in winter, and worst in May: and it is noted to be of eels, that the longer they live the better they are ("Angler's Sure Guide," p. 164). Of baits for the eel, the best are lob-worms, loach, minnows, small pope or pearch with the fins cut off, pieces of any fish, especially bleak, as being very lucid, with which $I$ have taken very large ones. As the angling for eels is no very pleasant amusement, and is always attended with great trouble and the risk of tackle, many, while they angle for other fish, lay lines for the eel, which they tie to weeds, flags, \&c., with marks to find them by ; or you may take a long packthread-line, with a leaden weight at the end, and hooks looped on at a yard distance from each other: fasten one end to the flags, or on the shore, and throw the lead out, and let the line lie some time; and in this way you may probably take a pike.-II.

[Nоте.-I do not think angling for eels worthy of the accomplished Piscator. When a boy, I used to catch them with night-lines baited with large worms, or: better with loach, which is the best night-line bait for perch, trout, and eels. When the rivers were flooded, I used to "bob" for eels, with a large bunch of worms, transversely threaded through different parts on worsted, and attached to about a yard and a half of whipcord. The rod should be very stout-in fact, a small pole twelve feet in length. When the eels bite, their teeth get entangled in the worsted, and you must suddenly and strongly whip them up ashore.-ED.]

* The taking flounders with a rod and line is a thing so accidental, that it is 
this, though it be most excellent meat, yet it wants scales, and is, as I told you, therefore an abomination to the Jews.

But, scholar, there is a fish that they in Lancashire boast very much of, called a CHAR; taken there (and I think there only), in a mere called Winander Mere: a mere, says Camclen, that is the largest in this nation, being ten miles in length, and (some say) as smooth in the bottom as if it were paved with polished marble. This fish never exceeds fifteen or sixteen inches in length; and is spotted like a trout: and has scarce a bone, but on the back. But this, though I do not know whether it make the angler sport, yet I would have you take notice of it, because it is a rarity, and of so high esteem with persons of great note.

Nor would I have you ignorant of a rare fish called a GUINIAD; of which I shall tell you what Camden and others speak. The river Dee (which runs by Chester), springs in Merionethshire; and, as it runs toward Chester, it runs through Pemble-Mere, which is a large water : and it is observed, that though the river Dee abounds with salmon, and Pemble-Mere with the guiniad, yet there is never any salmon caught in the mere, nor a guiniad in the river. And now my next observation shall be of the Barbel.

\section{CHAPTER XIV. \\ OBSERVATIONS OF THE BAREEL; AND DIRECTIONS HOW TO FISH FOR HIM.}

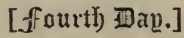

PIsc. The Barbel is so called, says Gesner, by reason of his barb or wattles at his mouth, which are under his nose or chaps. He is one of those leather-mouthed fishes, that I told you of, that does very seldom break his hold if he be once

hardly worth the mention. The same may be said of smelts, which, in the Thames, and other great rivers, are caught with a bit of any small fish, but chiefly of their own species. In the month of August, about the year 1720, such vast quantities of smelts came up the Thames, that women, and even children became anglers for them; and as I have been told by persons who well remembered it, in one day, between London-bridge and Greenwich, not fewer than two thousand persons were thus employed.-H. 
hooked: but he is so strong, that he will often break both rod and line, if he proves to be a big one.

But the barbel, though he be of a fine shape, and looks big, yet he is not accounted the best fish to eat, neither for his wholesomeness nor his taste: but the male is reputed much better than the female, whose spawn is very hurtful, as I will presently declare to you.

They flock together, like sheep, and are at the worst in April, about which time they spawn, but quickly grow to be in season. He is able to live in the strongest swifts of the water, and in summer they love the shallowest and sharpest streams ; and love to lurk under weeds, and to feed on gravel against a rising ground, and will root and dig in the sands with his nose like a hog, and there nest himself : yet sometimes he retires to deep and swift bridges, or flood-gates, or weirs, where he will nest himself amongst piles or in hollow places, and take such hold of moss or weeds, that be the water never so swift, it is not able to force him from the place that he contends for. This is his constant custom in summer, when he and most living creatures sport themselves in the sun : but at the approach of winter, then he forsakes the swift streams and shallow waters, and by degrees retires to those parts of the river that are quieter and deeper : in which places, and I think about that time, he spawns, and, as I have formerly told you, with the help of the melter, hides his spawn or eggs in holes, which they both dig in the gravel, and then they mutually labour to cover it with the same sand, to prevent it from being devoured by other fish.

There be such store of this fish in the river Danube, that Rondeletius says, they may in some places of it, and in some months of the year, be taken by those that dwell near to the river, with their hands, eight or ten load at a time : he says, they begin to be good in May, and that they cease to be so in August; but it is found to be otherwise in this nation : but thus far we agree with him, that the spawn of a barbel, if it be not poison, as he says, yet that it is dangerous meat, and especially in the month of May; which is so certain, that Gesner and Gasius declare it had an ill effect upon them, even to the endangering of their lives.*

* Though the spawn of the barbel is known to be of a poisonous nature, yet it is often taken by country people medicinally; who find it at once, a most powerful emetic and cathartic. And, notwithstanding what is said of the 
This fish is of a fine cast and handsome shape, with small scales, which are placed after a most exact and curious manner, and, as I told you, may be rather said not to be ill, than to be good meat : the chub and he have, I think, both lost part of their credit by ill cookery, they being reputed the worst or coarsest of fresh-water fish. But the BARBEL

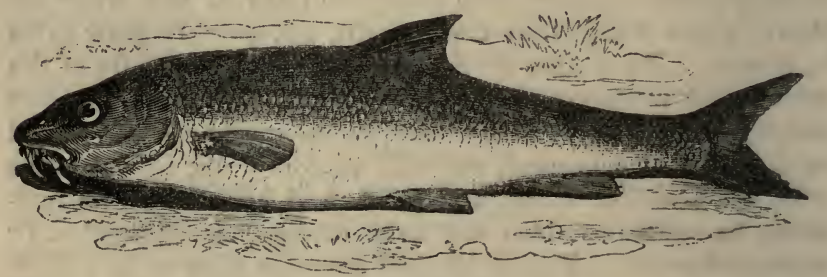

affords an angler choice sport, being a lusty and a cunning fish; so lusty and cunning as to endanger the breaking of the angler's line, by running his head forcibly towards any covert or hole or bank, and then striking at the line, to break it off, with his tail, as is observed by Plutarch in his book "De Industriâ Animalium ;" and also so cunning, to nibble and suck off your worm close to the hook, and yet avoid the letting the hook come into his mouth.

The barbel is also curious for his baits; that is to say, that they be clean and sweet; that is to say, to have your worms well scoured, and not kept in sour and musty moss, for he is a curious feeder; but at a well scoured lob-worm he will bite as boldly as at any bait, and especially if, the night or two before you fish for him, you shall bait the places where you

wholesomeness of the flesh, with some constitutions it produces the same effects as the spawn. About the month of September, in the year 1754, a servant of mine, who had eaten part of a barbel, though as I had cautioned him, he abstained from the spawn, was seized with such violent purging and vomiting, as had like to have cost him his life.-H.

[NoтE.-I doubt very much the truth of the alleged noxious properties either of the roe or the flesh of barbel when in condition, in the month of July, August, September, and October. Their edible qualities are bad-that is, tasteless. Dr. Bloch says, "the barbel, when not overgrown, is a sufficiently delicate fish;" and adds, that "himself, together with his whole family, had eaten the roe or spawn without any bad effect." I believe the latter part of the doctor's assertion, but I cannot subscribe to the former part of it. All the cooking in the world cannot render the flesh of barbel "sufficiently delicate." The Thames puntmen tell me, the only way of rendering barbel a passable relish is to fry slices of it with good rashers of fat bacon. I am inclined to agree with them.-ED.] 
intend to fish for him, with big worms cut into pieces ; $*$ and note, that none did ever overbait the place, nor fish too early or too late for a barbel. And the barbel will bite also at gentles, which not being too much scoured, but green, are a choice bait for him; and so is cheese, which is not to be too hard, but kept a day or two in a wet linen cloth to make it tough: with this you may also bait the water a day or two before you fish for the barbel, and be much the likelier to catch store; and if the cheese were laid in clarified honey a short time before, as namely, an hour or two, you are still the likelier to catch fish : some have directed to cut the cheese into thin pieces, and toast it, and then tie it on the hook with fine silk: and some advise to fish for the barbel with sheep's tallow and soft cheese beaten or worked into $a$ paste, and that it is choicely good in August, and I believe it ; but doubtless the lob-worm well scoured; and the gentle not too much scoured; and cheese ordered as I have directed, are baits enough, and I think will serve in any month, though I shall commend any angler that tries conclusions; and is industrious to improve the art. And now, my honest scholar, the long shower and my tedious discourse are both ended together ; and I shall give you but this observation, that when you fish for barbel, your rod and line be both long and of good strength, for, as I told you, you will find him a heavy and a dogged fish to be dealt withal, yet he seldom or never breaks his hold if he be once strucken. And if you would know more of fishing for the umber or barbel, get into favour with Doctor Sheldon, whose skill is above others ; and of that the poor that dwell about him have a comfortable experience.

And now let us go and see what interest the trouts will pay us for letting our angle-rods lie so long and so quietly in the water, for their use. Come, scholar, which will you take up?

VEN. Which you think fit, master.

Pisc. Why, you shall take up that, for I am certain, by viewing the line, it has a fish at it. Look you, scholar! well done! Come, now take up the other too: well! now you may tell my brother Peter, at night, that you have caught a leash of trouts this day. And now let's move towards our

* All this paragraph deserves the attention of the reader. The observations made in it prove that Walton was an expert barbel fisher.-ED. 
lodging, and drink a draught of red cow's milk as we go ; and give pretty Maudlin and her honest mother a brace of trouts for their supper.

VEN. Master, I like your motion very well; and I think it is now about milking-time; and yonder they be at it.

Prsc. God speed you, good woman! I thank you both for our songs last night: I and my companion have had such fortune a-fishing this day, that we resolve to give you and Maudlin a brace of trouts for supper; and we will now taste a draught of your red cow's milk.

MILK-W. Marry, and that you shall with all my heart; and I will still be your debtor when you come this way. If you will but speak the word, I will make you a good syllabub of new verjuice; and then you may sit down in a haycock, and eat it ; and Maudlin shall sit by and sing you the good old song of the "Hunting in Chevy Chase," or some other good ballad, for she hath store of them; Maudlin, my honest Maudlin, hath a notable memory, and she thinks nothing too good for you, because you be such honest men.

VEN. We thank you ; and intend once in a month, to call upon you again, and give you a little warning; and so, good night; good night, Maudlin. And now, good master, let's lose no time; but tell me somewhat more of fishing; and, if you please, first, something of fishing for a gudgeon.

PIsc. I will, honest scholar.

[REMARKS ON THE BARBEL.-Very little can be added to improve this excellent, and practically and prettily written chapter-practical for the greater part of it, and very pleasant towards its close. The river Lea, Walton's pet river, abounded in fine barbel in his day, and is not devoid of them now. So did the Thames, and it still does so. The best rivers in England for barbel, are the Thames and the Trent; and the best mode of fishing for the bearded, fluvial grenadier, is by means of the ledger-line. I'll tell you how it is made. On your foot-line of strong gut, about eighteen inches above the hook, fasten a number four shot, and twelve inches above that another shot of the same size. Between the shots the line should consist of gimp; and between them there must be a perforated bullet-freely so, to allow the gimp to run through easily. Instead of shots, double knots will answer. Your hook should be a number six, and your bait a large well-scoured lob-worm, or better, two middle-sized ones. Your winch line should run freely off the winch. Pull in your bullet to within a yard of the top of the rod, and then fling it to the spot which has been already ground-baited with lob-worms. When the bullet sinks, it will rock to and fro in the stream, and your worms will keep moving with it. When the bait is seized, the barbel will run with it until it is checked by the bullet coming 
in contact, and being arrested by the upper shot or bullet on the foot line. The angler immediately feels the check, and strikes smartly as he does so. Indeed, it often happens that the result of this check is the hooking of the fish, or at any rate the part hooking of him. The lower shot, or knot, prevents the bullet from running down on the bait. In fishing with the ledger-line, you cannot ground-bait too profusely for three or four nights before you begin to fish, and whilst you are doing so throw in, every half hour or so, a large ball of clay stuffed with worms, letting it drop by the spot at which your hook-bait lies. The worms for ground-bait should not be scoured, but those for hook-baits should be perfectly so. If you fish with one worm, put it on your hook thus : insert the point of the hook a little below the head into the throat of the worm, and then work it carefully up and beyond the shank, until not more than half an inch of the tail part projects at the point of the hook. You must take care in threading the worm, not to perforate it with the hook's point after the first perforation. When you use two worms on the hook at the same time-a practice I warmly advocate for perch and trout fishing, as well as for barbel-commence putting on the first worm as before, but bring the hook out at its middle, and then draw the worm above the shank of the hook: take then the second worm, and entering the hook about an inch, or half an inch, according to size, above the tail, work the worm up the hook until its head reaches within oneeighth of an inch of the point. Draw down the upper worm, until the tails of both come into close contact, and you will then have the best vermicular bait that can be used for large fish. If you angle with gentles, you must ground-bait with gentles, and you must fish with as many as you can put on a triangle of number six, seven or eight hooks. Barbel like a large bait, and in fishing for them with prepared cheese, greaves, salmon-roe, or bullock's pith, you must put on your hook of each the size of a large hazel nut. In worm fishing, the best hooks are those that are smoothly round in the bend; in fishing with gentles, pastes, \&c., the best are Kirby or Carlisle's "sneck-bend." The latter keep on fragile or fran-

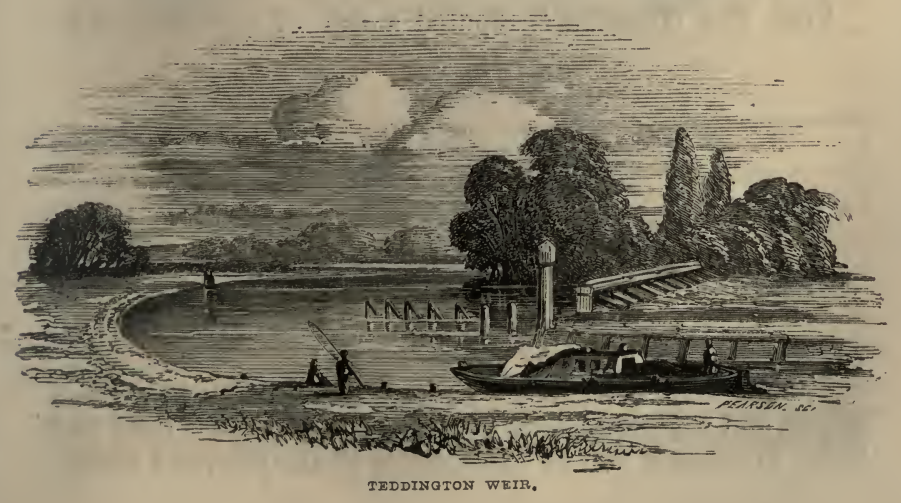


gible baits better than the former. Worms are early summer baits; pastes autumn and early winter ones.

The barbel is one of the largest of the carp tribe, and it is known to naturalists by the names, Cyprinus Barbus, and Barbus vulgaris; it has two beards, or wattles, at each side of the upper jaw, which is much longer than the lower one. It not unfrequently attains three feet in length, and is often caught in the Thames and Trent, weighing ten, twelve, and occasionally fourteen pounds. They are plentiful in all the deep running waters of those large rivers, from Twickenham to Sonning in the former, and several miles above and below Nottingham in the latter. It is a handsome and very powerful fish; olive-coloured on the back, and silver-hued on the belly. Its fins are large, especially the pectoral ones, and by their means it can stem the most rapid currents, and fight fiercely, when hooked, with the angler. In playing this fish, the line should always be kept taut, for if it be relaxed the fish will make for the bottom, or some stronghold, and seize between his leathern lips a root, or any substance he can with tenacity adhere to. Being a flatbellied fish, he feeds close to the bottom, and should be angled for with the bait lying upon it. In the summer months fish early and late for the barbel in deep streams. As soon as light frosts set in, barbel retire to still sheltered waters, and should be angled for only in the forenoon and afternoon. They do not bite well in long-continued dry weather, but do after heavy rains.-ED.]

\section{CHAPTER XV.}

OBSERVATIONS ON THE GUDGEON, THE RUFFE, AND THE BLEAK;

AND HOW TO FISH FOR THEM.

[frourth 政an.]

PIsc. The Gudgeon is reputed a fish of excellent taste,

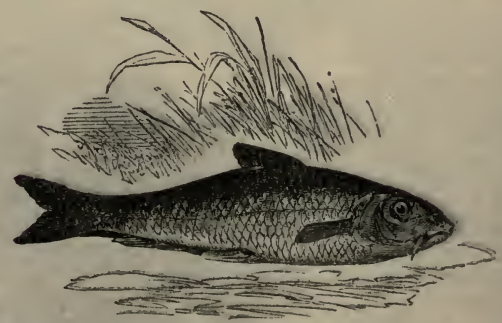

and to be very wholesome : he is of a fine shape, of a silver colour, and beautified with black spots both on his body and tail. He breeds two or three times in the year, and always 
in summer. He is commended for a fish of excellent nourishment: the Germans call him Groundling, by reason of his feeding on the ground; and he there feasts himself in sharp streams, and on the gravel. He and the barbel both feed so, and do not hunt for flies at any time, as most other fishes do : he is a most excellent fish to enter a young angler, being easy to be taken with a small red-worm, on or near to the ground. $\mathrm{He}$ is one of those leather-mouthed fish that has his teeth in his throat, and will hardly be lost off from the hook if he be once strucken.

They be usually scattered up and down every river in the shallows, in the heat of summer ; but in autumn, when the weeds begin to grow sour and rot, and the weather colder, they gather together, and get into the deep parts of the water, and are to be fished for there, with your hook always touching the ground, if you fish for him with a float, or with a cork; but many will fish for the Gudgeon by hand, with a running line upon the ground, without a cork, as a trout is fished for ; and it is an excellent way, if you have a gentle rod and as gentle a hand.*

There is also another fish called a POPE, and by some a

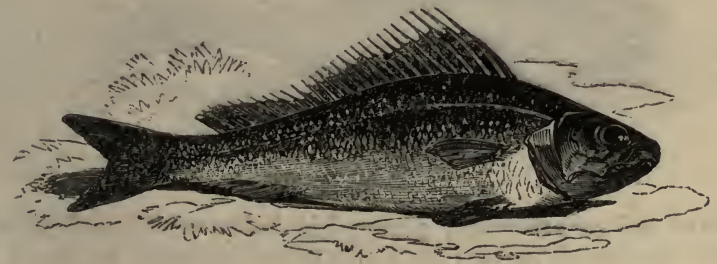

* In fishing for gudgeons, have a rake, and every quarter of an hour rake the bottom of the river, and the fish will flock thither in shoals. $-\mathrm{H}$.

[This note of Sir J. Hawkins is imperfect and obscure. In fi shing for gudgeon from a punt, it will not be necessary to rake the bottom of the river so long as you have bites. When they cease, the gravel must be raked up; in doing which, the water is muddied, and worms and larvæ very likely are stirred up. The gudgeon by instinct swim towards the spot, and as the water clears, take the angler's bait dropped thereon. As soon as nibbling ceases again, the punt is to be removed up or down stream a little, and the rake must once more be used. The process must be repeated, not "every guarter of an hour," but every time your bait ceases to be attacked. The cessation is caused by your having caught all the gudgeons on the spot, or by there not having been any there at all. Continual raking and continual change of ground are requisite to secure successful gudgeon-angling-a sort of pis-aller piscatorial pastime. $-\mathrm{ED}$. 
Rufre, a fish that is not known to be in some rivers: he is much like the pearch for his shape, and taken to be better than the pearch, but will not grow to be bigger than a gudgeon. He is an excellent fish, no fish that swims is of a pleasanter taste, and he is also excellent to enter a young angler, for he is a greedy biter ; and they will usually lie abundance of them together, in one reserved place, where the water is deep and runs quietly ; and an easy angler, if he has found where they lie, may catch forty or fifty, or sometimes twice as many, at a standing.

You must fish for him with a small red-worm; and if you bait the ground with earth, it is excellent.

There is also a bleak, or fresh-water sprat, a fish that is ever in motion, and therefore called by some the river-swallow; for just as you shall observe the swallow to be most evenings in summer ever in motion, making short and quick turns when he flies to catch flies in the air, by which he lives, so does the bleak at the top of the water. Ausonius would have him called BuEAK from his whitish colour : his back is of a

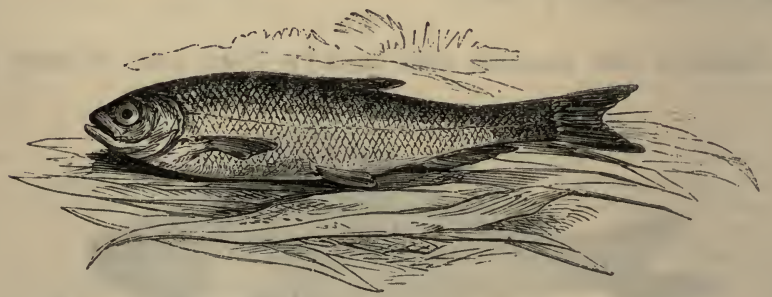

pleasant sad or sea-water green, his belly white and shining as the mountain snow; and doubtless, though he have the fortune, which virtue has in poor people, to be neglected, yet the bleak ought to be much valued, though we want Allamot salt, and the skill that the Italians have to turn them into anchovies. This fish may be caught with a Pater-noster line $; *$ that is, six or eight very small hooks tied along the

* A rosary, or string of beads, is used by the Roman-Catholic devotees to assist them in numbering their pater-nosters, or prayers; a line with many hooks at small distances from each other, though it little resembles a string of beads, is thence called a pater-noster line.-H.

[Every tenth bead on a rosary is larger than the others, so that when the devotee comes to it with his fingers, touching this large bead at the end of each tenth pater-noster, or Lord's prayer, he knows without the trouble of counting or looking, that he has repeated the prayers ten times. A rosary consists of 
line, one half a foot above the other: I have seen five caught thus at one time, and the bait has been gentles, than which none is better.

Or this fish may be caught with a fine small artificial fly, which is to be of a very sad brown colour, and very small, and the hook answerable. There is no better sport than whipping for bleaks in a boat, or on a bank, in the swift water, in a summer's evening, with a hazel top about five or six foot long, and a line twice the length of the rod. I have heard Sir Henry Wotton say, that there be many that in Italy will catch swallows so, or especially martins ; * this birdangler standing on the top of a steeple to do it, and with a line twice so long as I have spoken of. And let me tell you, scholar, that both martins and bleaks be most excellent meat.

And let me tell you, that I have known a hern that did constantly frequent one place, caught with a hook baited with a big minnow or small gudgeon. The line and hook must be strong, and tied to some loose staff, so big as she cannot fly away with it, a line not exceeding two yards.

several links of ten beads in each, between two larger beads. Rosaries are especially used by Roman Catholics when saying penitential prayers, enjoined by the confessor before he can grant absolution. For instance, so many paternosters and Are Marias, or I Iail Maries, for some particular sin confessed. Pater-noster lines are now generally used for perch-fishing. They seldom have more than three hooks, projecting, by means of being whipped on a pig's bristle, from the foot-line at least one foot apart. The hook nearest the bottom should be baited with a worm, the next with a live gudgeon or minnow, and that nearest the surface of the water with a gentle. Pike are frequently fished for with a very strong pater-noster, mounted with large hooks, each of which is to be baited with a live gudgeon, dace, roach, or small trout. This line is sunk by means of a bullet. See remarks at the end of Chapter XII.-ED.]

* Sir J. Hawkins says, this practice was common in England in his time. It is not so now. However, it frequently happens that when a fly-fisher is walking along the banks, or through the fields, with his rod held perpendicularly, and his artificial flies streaming behind in the air, that they are taken by swallows, swifts, martins, and several of the fly-catching tribe of birds. If artificial flies deceive fish, why should they not deceive birds?-ED.

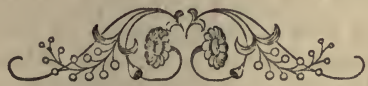




\section{CHAPTER XVI.}

IS OF NOTHING, OR THAT WHICH IS NOTHING WORTH.

\section{[fourth 进av.]}

PIsc. My purpose was to give you some directions concerning roach and dace, and some other inferior fish, which make the angler excellent sport, for you know there is more pleasure in hunting the hare than in eating her; but I will forbear at this time to say any more, because you see yonder comeour brother Peter and honest Coridon: but I will promise you, that as you and I fish, and walk to-morrow towards London, if I have now forgotten anything that I can then remember, I will not keep it from you.

Well met, gentlemen: this is lucky that we meet so just together at this very door. Come, hostess, where are you? Is supper ready? Come, first give us drink, and be as quick as you can, for I believe we are all very hungry. Well, brother Peter, and Coridon, to you both; come drink, and then tell me what luck of fish : we two have caught but ten trouts, ofwhich my scholar caught three; look, here's eight, and a brace we gave away: we have had a most pleasant day for fishing and talking, and are returned home both weary and hungry, and now meat and rest will be pleasant.

РЕт. And Coridon and I have had not an unpleasant day, and yet I have canght but five trouts : for indeed we went to a good honest ale-house, and there we played at shovel-board half the day; all the time that it rained we were there, and as merry as they that fished; and I am glad we are now with a dry house over our heads, for hark how it rains and blows. Come, hostess, give us more ale, and our supper with what haste you may: and when we have supped, let us have your song, Piscator, and the catch that your scholar promised us; or else Coridon will be dogged.

PIsc. Nay, I will not be worse than my word; you shall not want my song, and I hope I shall be perfect in it.

VEN. And I hope the like for my catch, which I have ready too: and therefore let's go merrily to supper, and then have a gentle touch at singing and drinking; but the last with moderation. 
Con. Come, now for your song; for we have fed heartily. Come, hostess, lay a few more sticks on the fire. And now sing when you will.

PIsc. Well then, here's to you, Coridon; and now for my song.

0 the gallant fisher's life,

It is the best of any !

'Tis full of pleasure, void of strife,

And 'tis beloved by many :

Other joys

Are but toys;

Only this

Lawful is ;

For our skill

Breeds no ill,

But content and pleasure.

In a morning up we rise

Ere Aurora's peeping;

Drink a cup to wash our eyes ;

Leave the sluggard sleeping.

Then we go

To and fro

With our knacks

At our backs

To such streams

As the Thames,

If we have the leisure.

When we please to walk abroad.

For our recreation,

In the fields is our abode,

Full of delectation:

Where in a brook,

With a hook,

Or a lake,

Fish we take;

There we sit

For a bit,

Till we fish entangle.

We have gentles in a horn,

We have paste and worms too;

We can watch both night and morn,

Suffer rain and storms too.

None do here

Use to swear ;

Oaths do fray

Fish away :

We sit still

And watch our quill ;

Fishers must not wrangle. 
If the sun's excessive heat

Make our bodies swelter,

To an osier-hedge we get

For a friendly shelter ;

Where in a dike,

Perch or pike,

Roach or dace,

We do chase ;

Bleak or gudgeon,

Without grudging :

We are still contented.

Or we sometimes pass an hour

Under a green willow, That defends us from a shower-

Making earth our pillow :

Where we may

Think and pray,

Before death,

Stops our breath :

Other joys

Are but toys,

And to be lamented.-Jo. Chalkhill.

VEN. Well sung, master : this day's fortune and pleasure, and this night's company and song, do all make me more and more in love with angling. Gentlemen, my master left me alone for an hour this day; and I verily believe he retired himself from talking with me, that he might be so perfect in this song: was it not, master?

Prsc. Yes, indeed ; for it is many years since I learned it, and having forgotten a part of it, I was forced to patch it up by the help of mine own invention, who am not excellent at poetry, as my part of the song may testify : but of that I will say no more, lest you should think I mean by discommending it to beg your commendations of it. And therefore, without replications, let us hear your catch, scholar, which I hope will be a good one; for you are both musical, and have a good fancy to boot.

Ven. Marry, and that you shall; and as freely as I would have my honest master tell me some more secrets of fish and fishing as we walk and fish towards London to-morrow. But, master, first let me tell you, that very hour which you were absent from me, I sat down under a willow tree by the waterside, and considered what you had told me of the owner of that pleasant meadow in which you had then left me; that he had a plentiful estate, and not a heart to think so; that he had at this time many law-suits depending, and that they 
both damped his mirth and took up so much of his time and thoughts, that he himself had not leisure to take the sweet content that I, who pretended no title to them, took in his fields:* for I could sit there quietly; and looking on the water, see some fishes sport themselves in the silver streams, others leaping at flies of several shapes and colours; looking on the hills, I could behold them spotted with woods and groves; looking down the meadows, could see, here a boy gathering lilies and lady-smocks, and there a girl cropping culverkeys and cowslips, all to make garlands suitable to this present month of May : these, and many other field-flowers, so perfumed the air, that I thought that very meadow like that field in Sicily of which Diodorus speaks, where the perfumes arising from the place make all dogs that hunt in it to fall off, and to lose their hottest scent. I say, as I thus sat, joying in my own happy condition, and pitying this poor rich man that owned this and many other pleasant groves and meadows about me, I did thankfully remember what my Saviour said, that the meek possess the earth; or rather, they enjoy what the others possess and enjoy not; for anglers and meek quiet-spirited men are free from those high, those restless thoughts, which corrode the sweets of life ; and they, and they only, can say, as the poet has happily expressed it:

Hail blest estate of lowliness !

Happy enjoyments of such minds

As, rich in self-contentedness,

Can, like the reeds in roughest winds,

By yielding make that blow but small,

At which proud oaks and cedars fall.

There came also into my mind, at that time, certain verses in praise of a mean estate and an humble mind; they were written by Phineas Fletcher, an excellent divine, and an excellent angler, and the author of excellent piscatory eclogues,

* There is so much fine and useful morality included in this sentiment, that to let it pass would be inexcusable in one who pretends to illustrate the author's meaning, or display his excellence. The precept which he evidently meant to inculcate, is a very comfortable one, viz., that some of the greatest pleasures human nature is capable of, lie open and in common to the poor as well as the rich. It is not necessary that a man should have the fee-simple of all the land in prospect from Windsor Terrace or Richmond Hill, to enjoy the beauty of those two delightful situations; nor can we imagine that no one but Lord Burlington was ever delighted in the view of his most elegant villa at Chiswick, now his grace the Duke of Devonshire's.-H. 
in which you shall see the picture of this good man's mind, and I wish mine to be like it.*

No empty hopes, no courtly fears him fright;

No begging wants his middle fortune bite :

But sweet content exiles both misery and spite.

His certain life, that never can deceive him,

Is full of thousand sweets and rich content;

The smooth-leaved beeches in the field receive him,

With coolest shade, till noontide's heat be spent.

His life is neither toss'd in boisterous seas

Or the vexatious world, or lost in slothful ease ;

Pleased and full bless'd he lives, when he his God can please.

His bed, more safe than soft, yields quiet sleeps,

While by his side his faithful spouse hath place ;

His little son into his bosom creeps,

The lively picture of his father's face ;

His humble house or poor state ne'er torment him-.

Less he could like, if less his God had lent him ;

And when he dies, green turfs do for a tomb content him.

Gentlemen, these were a part of the thoughts that then possessed me. And I here made a conversion of a piece of an old catch, and added more to it, fitting them to be sung by anglers. Come, master, you can sing well; you must sing a part of it as it is in this paper.

Peter. Ay marry, sir, this is music indeed; this has cheered my heart, and made me to remember six verses in praise of music, which I will speak to you instantly.

Music! miraculous rhetoric, that speakest sense

Without a tongue, excelling eloquence ;

With what ease might thy errors be excused,

Wert thou as truly loved as thou'rt abused!

But though dull souls neglect, and some reprove thee,

I cannot hate thee, 'cause the angels love thee.

VEN. And the repetition of these last verses of music has called to my memory what Mr. Ed. Waller, t a lover of the angle, says of love and music.

* It would be great injustice to the memory of this person, whose name is now hardly known, to pass him by without notice. He was the son of Giles Fletcher, doctor of laws, and ambassador from Queen Elizabeth to the Duke of Muscovy ; a fellow of King's College, Cambridge, and the author of a fine allegorical poem, intitled, "The Purple Island," printed at Cambridge, with other of his poems, in 4 to. 1633 ; from whence the passage in the text, with a little variation, is taken.-H.

$\dagger$ As the author's concern for the honour of angling induced him to enumerate such persons of note as were lovers of that recreation, the reader will allow me to add Mr. John Gay to the number. Any one who reads the first canto 
Whilst I listen to thy voice,

Chloris, I feel my heart decay :

That powerful noise

Calls my fleeting soul away :

0 suppress that magic sound,

Which destroys without a wound !

Peace, Cbloris, peace, or singing die,

That together you and I

To heaven may go ;

For all we know

Of what the blessed do above

Is-that they sing, and that they love.

Pisc. Well remembered, brother Peter : these verses came seasonably, and we thank you heartily. Come, we will all join together, my host and all, and sing my scholar's catch over again, and then each man drink the other cup, and to bed, and thank God we have a dry house over our heads.

PIsc. Well now, good night to everybody.

Peter. And so say I.

VEN. And so say I.

Cor. Good night to you all, and I thank you.

of his "Georgic," intitled " Rural sports," and observes how beautifully and accurately he treats the subject of fly-fishing, would conclude the author a proficient : but that it was his chief amusement, I have been assured, by an intimate friend of mine, who has frequently fished with him in the river Kennet, at Amesbury in Wilts, the seat of his grace the Duke of Queensberry.

The reader will excuse the following addition to this note, for the sake of a beautiful description of the material used in fly-making, which is quoted from the above-mentioned poem :-

"To frame the little animal, provide

All the gay hues that wait on female pride:

Let nature guide thee; sometimes golden wire

The shining bellies of the fly require;

The peacock's plumes thy tackle must not fail,

Nor the dear purchase of the sable's tail ;

Each gaudy bird some slender tribute brings,

And lends the growing insect proper wings;

Silks of all colours must their aid impart,

And every fur promote the fisher's art:

So the gay lady, with expensive care,

Borrows the pride of land, of sea, of air

Furs, pearls, and plumes, the glittering thing displays,

Dazzles our eyes, and easy hearts betrays."-H.

[Note.-Very few gaudy flies are necessary for artificial flies for the common trout. Sombre-hued are generally the best. All the materials, except silk, for making them are produced in this country, feathers and furs, except the yellow monkey's and bear's fur. It is only for salmon-fly materials that we are obliged to have recourse to the gaudy feathers of the birds of the New World, and of those of Africa and Asia. The common cock of different colours, the starling, the mallard, the partridge, the pheasant, the green and grey plover, the wren, grouse, tom-tit, red-wing, landrail, dotterel, furnish the usual feathers. The water-rat, squirrel, hedgehog, seal, spaniel, hare, cow, pig, furnish furs or woolly substances, which, together with mohair and floss-silk of different colours, are the general substances of which the bodies of trout-flies are fashioned.-ED.] 


\section{[ffifth) 田av.]}

Pisc. Good-morrow, brother Peter, and the like to you, honest Coridon : come, my hostess says there is seven shillings to pay : let us each man drink a pot for his morning's draught, and lay down his two shillings; that so my hostess may not have occasion to repent herself of being so diligent, and using us so kindly.

PETER. The motion is liked by everybody ; and so, hostess, here's your money: we anglers are all beholding to you, it will not be long ere I'll see you again. And now, brother Piscator, I wish you and my brother your scholar a fair day and good fortune. Come, Coridon, this is our way.

\section{CHAPTER XVII. \\ OF ROACH AND DACE, AND HOW TO FISH FOR THEM; \\ AND OF CADIS. \\ [ffifth 建av.]}

VEN. Good master, as we go now towards London, be still so courteous as to give me more instructions: for I have several boxes in my memory, in which I will keep them all very safe, there shall not one of them be lost.

Prsc. Well, scholar, that I will, and I will hide nothing from you that I can remember, and can think may help you forward towards a perfection in this art. And because we have so much time, and I have said so little of roach and dace, I will give you some directions concerning them.

Some say the Roach is so called from rutilus, which they say signifies red fins. He is a fish of no great reputation for his dainty taste; and his spawn is accounted much better than any part of him. And you may take notice, that as the carp is accounted the water-fox for his cunning; so the roach is accounted the water-sheep, for his simplicity or foolishness. It is noted, that the roach and dace recover strength, and grow in season, a fortnight after spawning; the barbel and ehub in a month : the trout in four months; and the salmon in the like time, if he gets into the sea, and after into fresh water. 
Roaches be accounted much better in the river than in a pond, though ponds usually breed the biggest. But there is a kind of bastard small roach, that breeds in ponds, with a very forked tail, and of a very small size; which some say is bred by the bream and right roach; and some ponds are stored with these beyond belief; and knowing-men, that know their difference, call them ruds; they differ from the true roach as much as a herring from a pilchard. And these bastard breed of roach are now scattered in many rivers ; but I think not in the Thames, which I believe afford the largest and fattest in this nation, especially below London Bridge.*

* I know not what roaches are caught below bridge, but above I am sure they are very large, for on the 15 th of September, 1754, at Hampton, I caught one that was fourteen inches and an eighth from eye to fork, and in weight wanted but an ounce of two pounds. The season for fishing for roach in the Thames begins about the latter end of August, and continues much longer than it is either pleasant or safe to fish. It requires some skill to hit the time of taking them exactly; for all the summer long they live on the weed, which they do not forsake for the deeps till it becomes putrid, and that is sooner or later, according as the season is wet or dry; for you are to know, that much rain hastens the rotting of the weed: I say it requires some skill to hit the. time; for the fishermen who live in all the towns along the river, from Chiswick. to Staines, are about this time nightly on the watch, as soon as the fish come out, to sweep them away with a drag-net; and our poor patient angler is left. baiting the ground, and adjusting his tackle, to eatch those very fish, which perhaps, the night before had been carried to Billingsgate. The Thames, as, well above as below London-bridge, was formerly much resorted to by the London anglers, and which is strange to think on, considering the unpleasantness of the station, they were used to fish near the starlings of the bridge. This will account for the many fishing-tackle shops that were formerly in Crookedlane, which leads to the bridge. In the memory of a person, not long since living, a waterman that plied at Essex-stairs, his name John Reeves, got a comfortable living by attending anglers with his boat; his method was, to watch when the shoals of roach came down from the country, and when he had found them, to go round to his customers and give them notice. Sometimes they settled opposite the Temple, at others, at Blackfriars or Queenhithe, but most frequently about the Chalk-hills, near London-bridge. His hire was two shillings a tide. A certain number of persons who were accustomed thus to employ him, raised a sum sufficient to buy him a waterman's coat and silver badge, the impress whereof was, himself with an angler in his boat, and he had annually a new coat to the time of his death.-H. Sir J. Hawkins adds as follows :- "Before I dismiss the subject of Thames fishing, I will let the reader know, that formerly the fishermen inhabiting the banks of the Thames, were used to inclose certain parts of the river with what they called stops, but which were in effect, weirs, or kidels, by stakes driven into the bed thereof, and to these they tied wheels, creating thereby a current, which drove the fish into those traps. This practice, though it may sound oddly to say so, is against Magna Charta, and is expressly prohibited by the twenty-third chapter of that statute : in the year 1757, the Lord Mayor Dickenson sent the water-bailiff up the Thames in a barge well manned and furnished with proper implements, who destroyed all those inclosures on this side of Staines, by pulling up the stakes and setting them adrift." - H.

[Roach has long disappeared from all parts of the Thames in the vicinity of 
The roach is a leather-mouthed fish, and has a kind of sawlike teeth in his throat. And lastly, let me tell you the roach makes an angler capital sport, especially the great roaches about London, where $I$ think there be the best roach anglers. And I think the best trout anglers be in Derbyshire : for the waters there are clear to an extremity.

Next, let me tell you, you shall fish for this RoACH

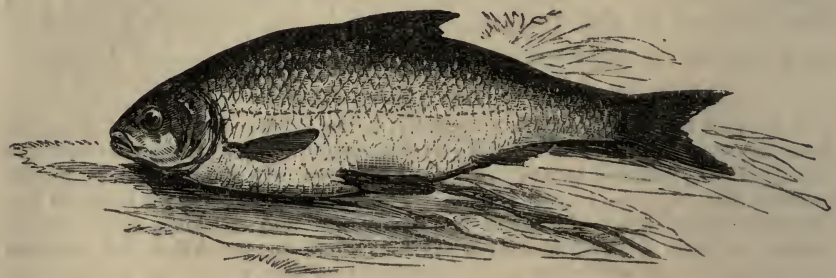

in winter with paste or gentles; in April, with worms or eadis ; in the very hot months with little white snails, or with flies under water, for he seldom takes them at the top, though the dace will. In many of the hot months, roaches may also be caught thus; take a May-fly or ant-fly, sink him with a little lead to the bottom, near to the piles or posts of a bridge, or near to any posts of a weir, I mean any deep place where roaches lie quietly, and then pull your fly up very leisurely, and usually a roach will follow your bait to the very top of the water, and gaze on it there, and run at it and take it, lest the fly should fly away from him.

I have seen this done at Windsor and Henley-bridge, and great store of roach taken, and sometimes a dace or chub; and in August you may fish for them with a paste made only

London. I would not advise any one to fish for roach nearer than at Richmond : a few may be taken at Kew or Isleworth, but Richmond is one of the best spots, just at the flow and ebb of the tide.

The river is now preserved from Isleworth to Staines by an excellent society, sanetioned by each successive Lord Mayor, who is ex-officio conservator of the Thames from the Medway to Staines, and called the "Thames Angling Preservation Society." The object of the Society, to the increase of whose funds all anglers should contribute, is to suppress poaching and illegal netting, and so augment the breed of fish. They have been hitherto successful to a great extent. The preservation of the River is taken up at Staines by the "Thames Trout Club," and continued to Maidenhead weir. This Ciub is also deserving of support, as is also one high up the river near Goring.-ED.] 
of the crumbs of bread, which should be of pure fine manchet; and that paste must be so tempered betwixt your hands, till it be both soft and tough too; a very little water, and time and labour, and clean hands, will make it a most excellent paste: but when you fish with it, you must have a small hook, a quick eye, and a nimble hand, or the bait is lost, and the fish too; if one may lose that which he never had. With this paste you may, as I said, take both the RoAcH and DACE or DARE, for they be much of a kind in matter of feeding,

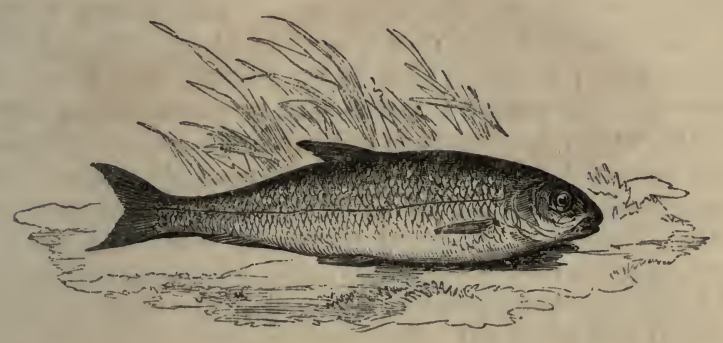

cunning, goodness, and usually in size. And therefore, take this general direction for some other baits which may concern you to take notice of. They will bite almost at any fly, but especially at ant-flies ; concerning which, take this direction, for it is very good:

Take the blackish ant-fly out of the mole-hill or ant-hill, in which place you shall find them in the month of June, or if that be too early in the year, then doubtless you may find them in July, August, and most of September ; gather them alive with both their wings, and then put them into a glass that will hold a quart or a pottle ; but first put into the glass a handful or more of the moist earth out of which you gather them, and as much of the roots of the grass of the said hillock, and then put in the flies gently, that they lose not their wings: lay a clod of earth over it, and then so many as are put into the glass without bruising, will live there a month or more, and be always in a readiness for you to fish with; but if you would have them keep longer, then get any great earthen pot, or barrel of three or four gallons, which is better, then wash your barrel with water and honey, and having put into it a quantity of earth and grass roots, then put in your flies, and 
cover it, and they will live a quarter of a year : these in any stream and clear water, are a deadly bait for roach or dace, or for a chub; and your rule is, to fish not less than a handful from the bottom.

I shall next tell you a winter bait for a roach, a dace, or chub, and it is choicely good. About All-hallowtide and so till frost comes, when you see men ploughing up heath ground, or sandy-ground or greenswards, then follow the plough, and you shall find a white worm as big as two maggots, and it hath a red head: you may observe in what ground most are, for there the crows will be very watchful and follow the plough very close; it is all soft, and full of whitish guts; a worm, that is, in Norfolk and some other counties, called a grub; and is bred of the spawn or eggs of a beetle, which she leaves in holes that she digs in the ground under cow or horse-dung, and there rests all winter, and in March or April comes to be first a red, and then a black beetle. Gather a thousand or two of these, and put them with a peck or two of their own earth, into some tub or firkin, and cover and keep them so warm that the frost or cold air or winds kill them not: these you may keep all winter, and kill fish with them at any time ; and if you put some of them into a little earth and honey, a day before you use them, you will find them an excellent bait for bream, carp, or indeed for almost any fish.

And after this manner you may also keep gentles all winter ; which are a good bait then, and much the better for being lively and tough. Or you may breed and keep gentles thus : take a piece of beast's liver, and with a cross stick, hang it in some corner, over a pot or barrel half full of dry clay: and as the gentles grow big, they will fall into the barrel and scour themselves, and be always ready for use whensoever you incline to fish; and these gentles may be thus created till after Michaelmas. But if you desire to keep gentles to fish with all the year, then get a dead cat or a kite, and let it be fly-blown; and when the gentles begin to be alive and to stir, then bury it and them in soft moist earth, but as free from frost as you can ; and these you may dig up at any time when you intend to use them : these will last till March, and about that time turn to be flies.

But if you will be nice to foul your fingers, which good anglers seldom are, then take this bait : get a handful of wellmade malt, and put into a dish of water ; and then wash and 
rub it betwixt your hands till you make it clean, and as free from husks as you can ; then put that water from it, and put a small quantity of fresh water to it, and set it in something that is fit for that purpose, over the fire, where it is not to boil apace, but leisurely and very softly, until it become somewhat soft, which you may try by feeling it betwixt your finger and thumb; and when it is soft, then put your water from it, and then take a sharp knife, and turning the sprout end of the corn upward, with the point of your knife take the back part of the husk off from it, and yet leaving a kind of inward husk on the corn, or else it is marred; and then cut off that sprouted end, I mean a little of it, that the white may appear, and so pull off the husk on the cloven side, as I directed you, and then cutting off a very little of the other end, that so your hook may enter; and if your hook be small and good, you will find this to be a very choice bait either for winter or summer, you sometimes casting a little of it into the place where your float swims.

And to take the roach and dace, a good bait is the young brood of wasps or bees, if you dip their heads in blood; especially good for bream, if they be baked or hardened in their husks in an oven, after the bread is taken out of it, or hardened on a fire shovel; and so also is the thick blood of sheep, being half dried on a trencher, that so you may cut it into such pieces as may best fit the size of your hook, and a little salt keeps it from growing black, and makes it not the worse but better : this is taken to be a choice bait if rightly ordered.

There be several oils of a strong smell that $I$ have been told of, and to be excellent to tempt fish to bite, of which I could say much; but I remember I once carried a small bottle from Sir George Hastings to Sir Henry Wotton, they were both chymical men, as a great present; it was sent and received, and used with great confidence; and yet upon inquiry, I found it did not answer the expectation of Sir Henry, which, with the help of this and other circumstances, makes me have little belief in such things as many men talk of : not but that I think fishes both smell and hear, as I have expressed in my former discourse ; but there is a mysterious knack, which, though it be much easier than the philosopher's stone, yet it is not attainable by common capacities, or else lies locked up in the brain or breast of some chymical man, that, like the Posicrucians, will not yet reveal it. But let me 
nevertheless tell you, that camphor, * put with moss into your worm-bag with your worms, makes them, if many anglers be not very much mistaken, a tempting bait, and the angler more fortunate. But I stepped by chance into this discourse of oils and fishes smelling; and though there might be more said, both of it and of baits for roach and dace and other float fish, yet I will forbear it at this time, $\uparrow$ and tell you in the

* All scented baits are now justly repudiated. Perfuming a worm or any other bait will do harm and not good.-ED.

$\dagger$ Roach delight in gravelly or sandy bottoms; their haunts, especially as winter approaches, are clear, deep, and still waters : at other times they lie in and near weeds, and under the shade of boughs. They spawn about the latter end of May, when they are scabby and unwholesome, but they are again in order in about three weeks : the largest are taken after Michaelmas, and their prime season is in February or March. The baits for roach, not already mentioned, are cad-bait and oak-worms for the spring; in May, ant's-eggs, and paste made of the crumbs of a new roll, both white and tinged with red, which is done by putting vermilion into the water wherewith you moisten it; this paste will do for the winter also. The largest roach in this kingdom are taken in the Thames, where many have been caught of two pounds and a half weight ; but roach of any size are hardly to be come at without a boat. The haunts of dace are gravelly, sandy, and clayey bottoms; deep holes that are shaded; water lily leaves, and under the foam caused by an eddy: in hot weather they are to be found on the shallows, and are then best taken with an artificial fly, grasshoppers, or gentles, as hereafter directed.

Dace spawn about the latter end of March, and are in season about three weeks after; they are not very good till about Michaelmas, and are best in February. Baits for dace, other than those mentioned by Walton, are the oakworm, red-worm, brandling, gilt-tail, and indeed any worm bred on trees or bushes, that is not too big for his mouth : almost all kinds of flies and caterpillars. Though dace are often caught with a float as roach, yet they are not so properly float-fish ; for they are to be taken with an artificial gnat, or antfly, or indeed, almost any other small fly in its season; but in the Thames, above Richmond, the largest are caught with a natural green or dun grasshopper, and sometimes with gentles; with both which you are to fish, as with an artificial fly; they are not to be come at till about September, when the weeds begin to rot; but when you have found where they lie, which in a warm day is generally on the shallows, 'tis incredible what havoc you may make: pinch off the first joint of the grasshopper's legs, put the point of the hook in at the head, and bring it out at the tail ; and in this way of fishing you will catch chub, especially if you throw under the boughs. It is true, there is less certainty of catching in this way than with a float or ground-bait: for which reason, I would recommend it only to those who live near the banks of that delightful river, between Windsor and Isleworth, who have or can command a boat for that purpose, and can take advantage of a still, warm, gloomy day; and to such it will afford much more diversion than the ordinary inartificial method of fishing in the deeps for roach and dace. In fishing at bottom for roach and dace, use for ground-bait, bread soaked about an hour in water, and an equal quantity of bran; knead them to a tough consistence, and make them up into balls, with a small pebble in the middle; and throw these balls in where you fish; but be sure you throw them up the stream, for otherwise they will draw the fish beyond the reach of your line. Fish for roach within six, and for dace, within three inches of the bottom.-H.

[The remarks contained in the above note, written upwards of sixty years, 
next place how you are to prepare your tackling; concerning which I will, for sport's sake, give you an old rhyme out of an old fish-book which will prove a part, and but a part, of what you are to provide.

My rod and my line, my float and my lead,

My hook and my plummet, my whetstone and knife, My basket, my baits both living and dead,

My net, and my meat (for that is the chief) :

Then I must have thread, and hairs green and small,

With mine angling-purse-and so you have all.

But you must have all these tackling, and twice so many more, with which, if you mean to be a fisher, you must store yourself; and to that purpose, I will go with you either to Mr. Margrave, who dwells amongst the booksellers in St. Paul's Churchyard, or to Mr. John Stubs, near to the Swan in Golden-lane; they be both honest men, and will fit an angler with what tackling he lacks.

VEN. Then, good master, let it be at —— for he is nearest to my dwelling; and I pray let us meet there the ninth of May next, about two of the clock, and I'll want nothing that a fisher should be furnished with.

PIsc. Well, and I'll not fail you (God willing) at the time and place appointed.

VEN. I thank you, good master, and I will not fail you: and, good master, tell me what baits more you remember, for it will not now be long ere we shall be at Tottenham Highcross, and when we come thither, I will make you some requital of your pains, by repeating as choice a copy of verses as any we have heard since we met together; and that is a proud word, for we have heard very good ones.

Pisc. Well, scholar, and I shall be then right glad to hear them; and I will, as we walk, tell you whatsoever comes in my mind, that I think may be worth your hearing. You may make another choice bait thus : take a handful or two of the best and biggest wheat you can get, boil it in a little milk, like as frumity is boiled; boil it so till it be soft, and then fry it very leisurely with honey, and a little beaten saffron dissolved in milk; and you will find this a choice bait, and good,

show that roach and dace fishing was well understood then. Much improvement has taken place since in the methods of taking these interesting little fish, and in the gear necessary for their successful capture. An explanation of them would be too long for a note, therefore I shall give it at the end of this chapter.-ED.] 
I think, for any fish, especially for roach, dace, chub, or grayling: I know not but that it may be as good for a river carp, and especially if the ground be a little baited with it. And you may also note that the spawn* of most fish is a

* Barker, who wrote very briefly but well about angling before Walton, seems to have been the first to discover that the ova of the salmon tribe were capital baits for several fresh-water fish. Indeed, they are a natural bait, because when salmon and salmonidæ are in the act of spawning, or depositing their ova for the purpose of procreation, they are watched, not only by varieties of their own genus and species, but by other fish, which devour the ova that are washed away from the spawning beds by the current, and frequently dart into the beds themselves to feed upon the spawn. It requires the united efiorts of the spawning fish to beat them off. Barker advises angling with the roe or spawn in its raw state, which is very inconvenient and defective. To remedy this it is now preserved, and the recipe for doing so is given underneath. Barker, writing to Lord Montague, his patron, says :-

"Noble Lord,-I have found an experience of late, which you may angle with, and take great store of this kind of fish. First, It is the best bait for a trout that I have seen in all my time; and will take great store, and not fail, if they be there. Secondly, It is a special bait for dace or dare, good for chub or bottlin, or grayling. The bait is the roe of a salmon or trout; if it be a large trout that the spawns be anything great, you may angle for the trout with the bait as you angle with the brandling, taking a pair of scissors, and cut so much as a large hazel nut, and bait your hook, so fall to your sport; there is no doubt of pleasure. If $I$ had known it but twenty years ago, I would have gained a hundred pounds only with that bait. I am bound in duty to divulge it to your honour, and not to carry it to my grave with me. I do desire that men of quality should have it that delight in that pleasure. The greedy angler will murmur at me, but for that $I$ care not.

"For the angling for the scale-fish, they must angle either with cork or quill, plumming their ground, and with feeding with the same bait, taking them asunder, that they may spread abroad, that the fish may feed and come to your place: there is no doubt of pleasure, angling with fine tackle; as single hair lines, at least five or six lengths long, a small hook, with two or three spawns. The bait will hold one week ; if you keep it on any longer, you must hang it up to dry a little: when you go to your pleasure again, put the bait in a little water, it will come in kind again."

Recipe for Preserving Salmon-Roe.-It should be taken from the female salmon a few days before she spawns, and the process of preservation should commence immediately. As soon as the roe is taken from the fish, it must be put in a capacious earthen pan, and cold water poured upon it. After a few minutes' immersion, pour off the cold water, and pour in tepid water. Wash the ova, and separate them delicately with your fingers, breaking none if you can help it. Remove from them all skin. Pour off the water, and add some more clean and warm. Continue to do so until the roe becomes quite clean, and freed from all film. The water must not be too hot-a little more than milk-warm. The last washing must be with cold water, which being drained off, place the roe in a hair sieve until it be dry. To every pound of completely cleansed roe put two ounces of ordinary salt, mixing well with the fingers, so that each ovum be salted. Drain off the brine afterwards by placing the roe in a sieve or cullender for a few hours. Place it, or rather spread it, on a shallow dish, set half horizontally at a moderate distance from the fire, and keep stirring with the handle of a wooden ladle, so that each pea of roe may dry separately, and that there be no adhesion between any. When dry set it to cool, and when quite cold pot it. Press it gently but closely down in 
very tempting bait, being a little hardened on a warm tile, and cut into fit pieces. Nay, mulberries, and those blackberries which grow upon briars, be good baits for chubs or carps: with these many have been taken in ponds, and in some rivers where such trees have grown near the water, and the fruits customarily dropped in it. And there be a hundred other baits, more than can be well named, which, by constant baiting the water, will become a tempting bait for any fish in it.

You are also to know, that there be divers kinds of cadis, or case-worms, that are to be found in this nation, in several distinct counties, and in several little brooks that relate to bigger rivers; as namely, one cadis called a piper, whose husk or case is a piece of reed about an inch long, or longer, and as big about as the compass of a two-pence. These worms being kept three or four days in a woollen bag, with sand at the bottom of it, and the bag wet once a day, will in three or four days turn to be yellow; and these be a choice bait for the chub or chavender, or indeed for any great fish, for it is a large bait.

There is also a lesser cadis-worm, called a cock-spur, being in fashion like the spur of a cock, sharp at one end; and the case or house, in which this dwells, is made of small husks and gravel and slime, most curiously made of these, even so as to be wondered at, but not to be made by man no more than a king-fisher's nest can, which is made of little fishes' bones, and have such a geometrical interweaving and connection, as the like is not to be done by the art of man : this kind of cadis is a choice bait for any float-fish; it is much less than the piper-cadis, and to be so ordered; and these may be so preserved, ten, fifteen, or twenty days, or it may be longer.

There is also another cadis, called by some a straw-worm, and by some a ruff-coat, whose house or case is made of little pieces of bents, and rushes, and straws, and water-weeds, and

earthen pots, over which tie a piece of linen or bladder, on to which you have melted a layer of lard. To bait with salmon-roe, take a fine needle, threaded with fine red silk, knotted at the end. Pass the needle and silk through as many roe as will cover your hook from the point to beyond the shank. Insert the roe at the knotted end of the silk, on the point of your hook, and then wind the others side by side in the bend and up the shank of the hook a little beyond the arming. There fasten your silk, and cut away the end of it. Two or three roe will be sufficient for small fish; from six to a dozen for the middle and large-sized ones.-ED. 
I know not what, which are so knit together with condensed slime, that they stick about her husk or case, not unlike the bristles of a hedgehog; these three cadises are commonly taken in the beginning of summer, and are good indeed to take any kind of fish, with float or otherwise. I might tell you of many more, which as these do early, so those have their time also of turning to be flies later in summer; but $I$ might lose myself and tire you by such a discourse: I shall therefore but remember you, that to know these and their several kinds, and to what flies every particular cadis turns, and then how to use them, first as they be cadis, and after as they be flies, is an art, and an art that every one that professes to be an angler has not leisure to search after, and, if he had, is not capable of learning.

I will tell you, scholar, several countries have several kinds of cadises, that indeed differ as much as dogs do ; that is to say, as much as a very cur and a greyhound do. These be usually bred in the very little rills, or ditches, that run into bigger rivers : and I think, a more proper bait for those very rivers than any other. I know not how or of what, this cadis receives life, or what coloured fly it turns to ; but doubtless they are the death of many trouts; and this is one killing way:

Take one, or more if need be, of these large yellow cadis: pull off his head, and with it pull out his black gut; put the body, as little bruised as is possible, on a very little hook, arned on with a red hair, which will show like the cadis head: and a very little thin lead, so put upon the shank of the hook that it may sink presently. Throw this bait, thus ordered, which will look very yellow, into any great still hole where a trout is, and he will presently venture his life for it, it is not to be doubted, if you be not espied; and that the bait first touch the water before the line. And this will do best in the deepest water.

Next let me tell you, I have been much pleased to walk quietly by a brook with a little stick in my hand, with which I might easily take these, and consider the curiosity of their composure : and if you shall ever like to do so, then note, that your stick must be'a little hazel or willow, cleft, or have a nick at one end of it; by which means you may with ease take many of them in that nick out of the water, before you have any occasion to use them. These, my honest scholar, are some observations told to you as they now come suddenly 
into my memory, of which you may make some use ; but for the practical part, it is that that makes an angler : it is diligence, and observation, and practice, and an ambition to be the best in the art, that must do it.* I will tell you, scholar, I once heard one say, "I envy not him that eats better meat than I do, nor him that is richer, or that wears better clothes than I do; I envy nobody but him, and him only, that catches more fish than I do." And such a man is like to prove an angler; and this noble emulation $I$ wish to you and all young anglers.

[ROACH AND DACE Fisming.-The text of the preceding chapter contains much useful information on angling for roach and dace, and on the procnring and preserving of gentles and other baits. I shall not have a great deal to add to it. There are no better elementary exercises for

* The author has now done describing the several kinds of fish, excepting the few little ones that follow, with the different methods of taking them, but has said little or nothing of float-fishing; it may not be amiss here to lay down some rules about it. Let the rod be light and stiff, and withal so smart in the spring, as to strike at the tip of the whalebone; from fourteen to fifteen feet is a good length. In places where you sometimes meet with barbel, as at Shepperton and Hampton, in Middlesex, the fittest line is one of six or seven hairs at top; and so diminishing for two yards, let the rest be strong Indian grass, to within about half a yard of the hook, which may be whipped to a fine grass or silk-worm cut; and this line will kill a fish of six pounds weight. But for mere roach and dace fishing, accustom yourself to a singlehair line, with which an artist may kill a fish a pound and a half weight. For your float, in slow streams, a neat round goose-quill is proper; but for deep or rapid rivers, or in an eddy, the cork, shaped like a pear, is indisputably the best; which should not, in general, exceed the size of a nutmeg; let not the quill, which you put through it, be more than half an inch above and below the cork; and this float, though some prefer a swan's quill, has great advantage over a bare quill; for the quill being defended from the water by the cork, does not soften, and the cork enables you to lead your line so heavily, as that the hook sinks almost as soon as you put it into the water; whereas, when you lead but lightly, it does not get to the bottom till it is near the end of your swim. In leading your lines, be careful to balance them so nicely, that a very small touch will sink them; some use for this purpose lead shaped like a barley-corn, but there is nothing better to lead with than shot, which you must have ready cleft always with you; remembering that when you fish fine, it is better to have on your line a great number of small than a few large shot. Whip the end of the quill round the plug with fine silk, well waxed; this will keep the water out of your float, and preserve it greatly. In fishing with a float, your line must be about a foot shorter than your rod; for if it is longer, you cannot so well command your hook when you come to disengage your fish.-H.

[I give the above note because it contains some instructions by which the angler may make a few necessary articles. Residents in towns need not make them, as they will find them at the fishing-tackle shops ready made, cheaper and better than they can be made by amateur hands. Nothing can exceed the excellence of the floats sold at the shops, and cork floats are sold cheaply of every size, shape and colour. Hair bottom lines are almost obsolete, for gut can be found finer and stronger than hair.-ED.] 
young anglers, than those that can be gone through in fishing for roach and dace. He that succeeds in bottom-fishing well for roach, and in flyfishing for dace, will soon, if he have ambition, be able to cope with the largest of the carp tribe, with the salmon, and his numerous family, from the sea-trout to the grayling. I cannot conceive why Walton should have written, "that the roach is accounted the water-sheep for his simplicity "and foolishness." In my opinion, the roach, next to the carp, is the "cutest" member of the race. Under water he is tormentingly shy, and unless you tempt him with the most delicate baits, and the very finest tackle, you will have no chance of alluring him. Roach fishing requires the smallest hooks, the thinnest foot-line, and a very long, very light, and moderately elastic rod. Your float of prepared quill should yield to a next to imperceptible nibble. See what the late Mr. Blaine says of this bashful and pretty fish.- "The best season for roach fishing is from autumn until the following spring. In May they usually spawn; occasionally it is both earlier and later: after they have spawned, they continue out of season for several weeks, hardly recovering until the latter end of July, which is not to be wondered at when we consider the debilitating effect of such a quantity of ova, the grains of which, in a single fish, have been reckoned, and were found to amount to fifty-four thousand, which must consequently require a very copious supply of milt from the male to fecundate. Roach angling offers much interest to the piscatory zealots, who are shut out from the higher pursuits of fly-fishing. The roach is an elegant fish when taken, and we have shown that it requires some skill to deceive it, while its game qualities are such that it contests the matter with the angler to the last, so as to yield no small triumph when landed. We have seen a roach of a pound weight in a strong current in the Thames, raise the blood to the face of an angler of fair fame. They also, when in condition, bite freely; but we consider the principal hold they have, or ought to have on the angler, is, their great plenty, the numerous methods that may be employed to take them, to which may be added, the time of the year that sport may be obtained with them, which is, when few other fish yield any. From the bottom of the water, every inch of the way up to the surface, they may be fished for in various manners; and when they are sunning themselves at the top, they will take a fly with the best. No fish whatever exerts the capabilities of the angler so much as this: even the grayling (whose versatility in yielding sport is great also) must nevertheless give place to the roach, a precedence which, we think, will always rank it as a distinguished member in the piscatory list; and this opinion, from one devotedly fond of fly-fishing, may be considered as something in favour of its tribe and qualities." The best baits for roach are, clean simple or sweet pastes, and good small gentles; and in the spring months, small well-scoured brandlings and little red worms. In summer and autumn they will take artificial flies, little red, brown, and black hackles, small duns, the black gnat, and red and brown artificial ant-flies. They will take these flies best, if they be sunk four or six inches under water. A thin strip of light yellow kid leather, wound from the tail of the artificial fly, nearly as far as the barb of the hook, will be an improvement. Foot-lines for roach are fre- 
quently made of single horse-hair of a light brown colour. Perhaps they are the best, but as gut can be had finer than horse-hair and much stronger, I think it preferable. Between the float and the top of the rod there should not be more than a yard of line, and it should descend from the rod's point perpendicularly. Prompt striking, with an oblique twist, of the wrist is necessary.

The dace is a merry little fellow, reckless and gamesome, and therefore I like him much. He bites at the bottom more freely than the roach, and takes an artificial fly on the surface far more eagerly. He is the very best fish to initiate the youthful Cotton into the art and mysteries of that by far the most pleasant of piscatory practices-fly-fishing. They fiequent shallows, rapids, and eddies, and in them they will take well the artificial flies recommended for roach. In the late summer and early autumn months they prefer deep, still, sheltered waters, and then must be angled for with paste and gentles. In spring and early summer they take small worms with avidity. There are plenty of them in the Lea, and the Colne is famous for them of large size. In the latter river they take the artificial fly as eagerly as trout or grayling. In the shallows at Isleworth, Twickenham, Richmond, Teddington, Thames Ditton, Hampton, Sunbury, Walton, Halliford, Weybridge, Shepperton, Laleham, Chertsey, Penton Hook, Staines, and indeed, in all the streams up to Henley and beyond it. With an exeellent extract from Blaine, and one from Captain Williamson, I shall conclude the subject of dace fishing. Blaine truly says, "Dace bottom-fishing is not very different from that for roach, and the one is frequently taken when trying for the other, particularly in the autunn, when both retire for a while into the deep currents of rivers. Thus it is that roach and dace fishing is at that time a common sport, as it were, but does not eontinue long so; for dace, during the dead winter months, retreat to still deeps, and are not so easily tempted to bite then as roach. Dace are also often taken, with barbel, in the autumn months, which shows that they are then beginning to feed low, and are very seldom tempted by the fly at the surface afterwards. The tackle for dace bottom-angling should be similar to that for roach, and the baits also should be the same. To roach fishing, therefore, we refer our reader for the necessary information; but it may be observed, that when dace are purposely fished for, witlout reference to the taking of roach, a larger hook and larger bait may be used; and if the water be strong, for instance, as a mill-race, ete. etc., employ a gut-line and cork float. During the spring season, worms of most kinds (but the red in particular), caddies, larvæ of beetles, or grubs and bobs of all sorts, as well as small eaterpillars, are proper baits; for they all form, at this period, the natural food of dace. In this way they will take small watersnails also. In the hot summer months, gentles take the lead; in autumn, greaves and pastes, particularly salmon-roe, are killing. Like roach, they are more frequently taken at the bottom than at mid-water; a tripping-bait is, therefore, the best for them in general cases, but during the summer months it is not always necessary to fish so deep. On the contrary, caddies, bobs, and worms, are often taken by them more readily in currents at nine or ten inches from the ground, or even a little 
below mid-water at great depths. In shallows of two or three feet deep only, particularly in such as lie in the angle of two sharp streams, or where a swift brook enters a river, or between the race-courses of millwheels, where there is a sort of still back-water, set the bait to within four inches of the ground. In these spots dace are usually found waiting for the worms and insects that may be brought down, and which, as the eddy whirls them into the still, by its circular impetus, present themselves to the fish in the most tempting form. To imitate this, use a light line with a very fine cork, or large quill float, drop it within the edge of the current, so as to gain from it the circular motion for the bait you offer, which may be worm, gentle, or caddis, etc. By this method dace after dace may be taken, as fast nearly as you drop in the line; and we have ourselves, in such situations, basketed two or three dozen at a time. In most other cases, however, they are not so stationary as roach, and it is necessary to shift the fishing ground often to meet with them. Dace bite sharp, and must be struck quickly; they also plunge violently at first, and should the tackle be very fine, they must be guardedly played, or they may endanger it." Ground-baiting for dace over-night is not absolutely necessary, but follow Captain Williamson's advice, viz.: "In dace-fishing throw in now and then some balls made of brown (by roasting) oatmeal and treacle, or some coarsely ground malt." The roach is called Cyprinus Rutilus, from the red colour of its fins; the dace Cyprinus Alburnus, from the bright hue of its scales and belly. I recommend the latter to the patient pursuit of the incipient fly-fisher; the former to the steady perseverance of the young bottomfisher.-ED.]

\section{CHAPTER XVIII.}

OF THE MINNOW OR PENK, OF THE LOACH, AND OF THE BULL-HEAD OR MILLER'S THUMB.

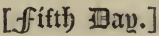

PIsc. There be also three or four other little fish that I had almost forgot, that are all without scales, and may for excellency of meat be compared to any fish of greatest value and largest size. They be usually full of eggs or spawn all the months of summer ; for they breed often, as it is observed mice, and many of the smaller four-footed creatures of the earth do ; and as those, so these, come quickly to their full growth and perfection. And it is needful that they breed both often and numerously, for they be, besides other accidents of ruin, both a prey and baits for other fish. And first, I shall tell you of the Minvow or PeNK. 
The minnow hath, when he is in perfect season, and not sick, which is only presently after spawning, a kind of dappled or waved colour, like to a panther, on his sides, inclining to a greenish and sky-colour, his belly being. milk white, and his back almost black or blackish. He is a sharp biter at a small worm, and in hot weather makes excellent sport for young anglers, or boys, or women that love that recreation, and in the spring they make of them excellent minnow-tansies; for being washed well in salt, and their heads and tails cut off, and their guts taken out, and not washed after, they prove excellent for that use ; that is, being fried with yolks of eggs, the flowers of cowslips, and of primroses, and a little tansy; thus used they make a dainty dish of meat.

The LoACH is, as I told you, a most dainty fish ; he breeds and feeds in little and clear swift brooks or rills, and lives there upon the gravel, and in the sharpest streams : he grows not to be above a finger long, and no thicker than is suitable to that length. This loach is not unlike the shape of the eel ; he has a beard or wattles like a barbel. He has two fins at his sides, four at his belly, and one at his tail ; he is dappled with many black or brown spots, his mouth is barbel-like under his nose. This fish is usually full of eggs or spawn; and is by Gesner, and other learned physicians, commended for great nourishment, and to be very grateful both to the palate and stomach of sick persons: he is to be fished for with a very small worm at the bottom, for he very seldom or

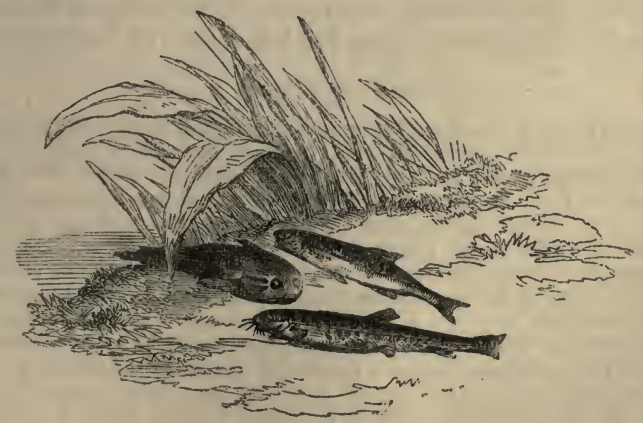


never rises above the gravel, on which I told you he usually gets his living.

The Miller's-Thumb, or Bull-head, is a fish of no pleasing shape.

$\mathrm{He}$ is by Gesner compared to the sea-toad-fish, for his similitude and shape. It has a liead big and flat, much greater than suitable to his body; a mouth very wide, and usually gaping; he is without teeth, but his lips are very rough, much like to a file. He hath two fins near to his gills, which be roundish or crested; two fins also under the belly; two on the back; one below the vent; and the fin of his tail is round. Nature hath painted the body of this fish with whitish, blackish, and brownish spots.* They be usually full of eggs or spawn all the summer, I mean the females; and those eggs swell their vents almost into the form of a dug. They begin to spawn about April, and, as I told you, spawn several months in the summer. And in the winter, the minnow, and loach, and bull-head, dwell in the mud, as the eel doth; or we know not where, no more than we know where the cuckoo and swallow, and other half-year birds, which first appear to us in April, spend their six cold, winter, melancholy months. This fish does usually dwell, and hide himself, in holes, or amongst stones in clear water ; and in very hot days will lie a long time very still, and sun himself, and will be easy to be seen upon any flat stone, or any gravel ; at which time he will suffer an angler to put a hook, baited with a small worm, very near unto his mouth; and he never refuses to bite, nor indeed to be caught with the worst of anglers. Matthiolust commends him much more for his taste and nourishment, than for his shape or beauty.

\footnotetext{
* Since Walton wrote, there has been brought into England, from Germany, a species of small fish, resembling carp in shape and colour, called "crusians," with which many ponds are now plentifully stocked. There have also been brought hither from China those beautiful creatures, gold and silver fish: the first are of an orange colour, with very shining scales, and finely variegated with black and dark brown; the silver fish are of the colour of silver tissue, with scarlet fins, with which colour they are curiously marked in several parts of the body. These fish are usually kept in ponds, basins, and small reservoirs of water, to which they are a delightful ornament. And it is now a very common practice to keep them in a large glass vessel like a punch-bowl, with fine gravel strewed at the bottom ; frequently changing the water, and feeding them with bread and gentles. Those who can take more pleasure in angling for than in beholding them (which I confess I could never do), may catch them with gentles; but though costly, they are but coarse food.-H.

$\dagger$ Petrus Andreas Matthiolus, of Sienna, an eminent physician of the
} 
There is also a fish called a Sticklebag, a fish without scales, but hath his body fenced with several prickles. I know not where he dwells in winter, nor what he is good for in summer, but only to make sport for boys and womenanglers, and to feed other fish that be fish of prey, as trout in particular, who will bite at him as at a penk, and better, if your hook be rightly baited with him; for he may be so baited as, his tail turning like the sail of a windmill, will make him turn more quick than any penk or minnow can. For note, that the nimble turning of that, or the minnow, is the perfection of minnow fishing. To which end, if you put your hook into his mouth, and out at his tail, and then, having first tied him with white thread a little above his tail, and placed him after such a manner on your hook, as he is like to turn, then sew up his mouth to your line, and he is like to turn quick, and tempt any trout; but if he do not turn quick, then turn his tail a little more or less towards the inner part, or towards the side of the hook, or put the minnow, or sticklebag, a little more crooked or more straight on your hook, until it will turn both true and fast, and then doubt not but to tempt any great trout that lies in a swift stream.* And the loach that I told you of will do the like : no bait is more tempting, provided the loach be not too big.

And now, scholar, with the help of this fine morning, and your patient attention, I have said all that my present memory will afford me, concerning most of the several fish that are usually fished for in fresh waters.

VEN. But, master, you have, by your former civility, made me hope that you will make good your promise, and say something of the several rivers that be of most note in this nation; and also of fish-ponds, and the ordering of them; and do it, I pray, good master, for I love any discourse of rivers, and fish and fishing; the time spent in such discourse passes away very pleasantly.

sixteenth century, famous for his commentaries on some of the writings of Dioscorides.

* See remarks on spinning for trout at the close of chap. 5.-ED. 
CHAPTER XIX.

OF SEVERAL RIVERS, AND SOME OBSERVATIONS OF FISH.

\section{[f(fth) 建an.]}

PISc. Well, scholar, since the ways and weather do both favour us, and that we yet see not Tottenham Cross, you shall see my willingness to satisfy your desire. And first, for the rivers of this nation, there be, as you may note out of Doctor Heylin's Geography, and others, in number 325, but those of chiefest note he reckons and describes as followeth :

1. The chief is Thamesis, compounded of two rivers, Thame and Isis, whereof the former, rising somewhat beyond Thame in Buckinghamshire, and the latter near Cirencester in Gloucestershire, meet together about Dorchester in Oxfordshire ; the issue of which happy conjunction is the Thamesis, or Thames; hence it flieth between Berks, Buckinghamshire, Middlesex, Surrey, Kent, and Essex : and so weddeth himself to the Kentish Medway, in the very jaws of the ocean. This glorious river, feeleth the violence and benefit of the sea more than any river in Europe, ebbing and flowing twice a day, more than sixty miles; about whose banks are so many fair towns and princely palaces that a German* poet thus truly spake :

$$
\text { "Tot campos," etc. }
$$

We saw so many woods and princely bowers, Sweet fields, brave palaces, and stately towers, So many gardens dress'd with curious care, That Thames with royal Tiber may compare.

2. The second river of note is Sabrina, or Severn; it hath its beginning in Plynlimmon-hill in Montgomeryshire, and his end seven miles from Bristol, washing, in the mean space, the walls of Shrewsbury, Worcester, and Gloucester, and divers other places and palaces of note.

* Who this German poet was I cannot find ; but the verses, in the original Latin, are in "Heylin's Cosmography," p. 240, and are as follow :-

Tot campos, sylvas, tot regia tecta, tot hortos, Artifici excultos dextra, tot vidimus arces;

Ut nune Ausonio, Thamesis, cum Tibride certet.-H. 
3. Trent, so called from thirty kind of fishes* that are found in it, or for that it receiveth thirty lesser rivers ; who, having its fountain in Staffordshire, and gliding through the counties of Nottingham, Lincoln, Leicester, and York, augmenteth the turbulent current of Humber, the most violent stream of all the isle. This Humber is not, to say truth, a distinct river, having a spring-head of his own, but it is rather the mouth or æstuarian of divers rivers here confluent, and meeting together, namely, your Derwent, and especially of Ouse and Trent; and (as the Danow, having received into its channel the river Dravus, Savus, Tibiscus, and divers others) changeth his name into this of Humberabus, as the old geographers call it.

4. Medway, a Kentish river, famous for harbouring the royal navy.

5. Tweed, the north-east bound of England; on whose northern banks is seated the strong and impregnable town of Berwick.

6. Tyne, famous for Newcastle, and her inexhaustible coalpits. These, and the rest of principal note, are thus comprehended in one of Mr. Drayton's sonnets.

Our floods' queen, Thames, for ships and swans is crown'd; And stately Severn for her shore is praised;

The crystal Trent, for fords and fish renown'd ; And Aron's fame to Albion's cliff's is raised.

Carlegion Chester vaunts her holy Dee ; York many wonders of her Ouse can tell ;

The Peak, her Dove, whose banks so fertile be; And Kent will say, her Medway doth excel.

Cotswold commends her Isis to the Thame ; Our northern borders boast of Tweed's fair flood;

Our western parts extol their Willy's fame; And the old Lea brags of the Danish blood. $†$

These observations are out of learned Dr. Heylin, and my old deceased friend, Michael Drayton; and because you say you love such discourses as these, of rivers and fish and fishing, I love you the better, and love the more to impart them to you ; nevertheless, scholar, if I should begin but to name

* Some say because it has thirty (trente) tributaries. It is more likely that the Trent had that number of streams, great and small, running into it, than that it ever produced thirty different varieties of fish.-ED.

$\dagger$ The Danes, in the time of King Alfred, entered the Lea; and ascending it in their small ships to a distance of twenty miles, built a castle on its banks near Hertford or Ware: hence the allusion, "Danish blood."-ED. 
the several sorts of strange fish that are usually taken in many of those rivers that run into the sea, I might beget wonder in you, or unbelief, or both; and yet I will venture to tell you a real truth concerning one lately dissected by Dr. Wharton, a man of great learning and experience, and of equal freedom to communicate it; one that loves me and my art; one to whom I have been beholden for many of the choicest observations that I have imparted to you. This good man, that dares to do anything rather than tell an untruth, did, I say, tell me he had lately dissected one strange fish, and he thus described it to me:

"The fish was almost a yard broad, and twice that lengtl ; his mouth wide enough to receive, or take into it, the head of a man; his stomach seven or eight inches broad. He is of a slow motion, and usually lies or lurks close in the mud, and has a moveable string on his head, ahout a span or near unto a quarter of a yard long, by the moving of which, with his natural bait, when he lies close and unseen in the mud, he draws other fish so close to him that he can suck them into his mouth, and so devours and digests them."

And, scholar, do not wonder at this, for besides the credit of the relator, you are to note, many of these, and fishes that are of the like and more unusual shapes, are very often taken on the mouths of our sea-rivers, and on the sea-shore. And this will be no wonder to any that have travelled Egypt; where 'tis known, the famous river Nilus does not only breed fishes that yet want names, but by the overflowing of that river, and the help of the sun's heat on the fat slime which that river leaves on the banks when it falls back into its natural channel, such strange fish and beasts are also bred, that no man can give a name to, as Grotius, in his "Sophom," and others, have observed.

But whither am I strayed in this discourse. I will end it by telling you, that at the mouth of some of these rivers of ours herrings are so plentiful, as namely, near to Yarmouth in Norfolk, and in the west country, pilchers so very plentiful, as you will wonder to read what our learned Camden relates of them in his "Britannia," p. 178, 186.

Well, scholar, I will stop here, and tell you what by reading and conference I have observed concerning fish-ponds. 


\section{CHAPTER XX.}

OF FISI-PONDS, AND HOW TO ORDER THEM.

\section{[fifth) 建av.]}

Prsc. Doctor Lebault, the learned Freuchman, in his large discourse of Maison Rustique, ${ }^{*}$ gives this direction for making of fish-ponds; I shall refer you to him to read at large, but I think I shall contract it, and yet make it as useful.

He adviseth, that when you have drained the ground, and made the earth firm where the head of the pond must be, that you must then, in that place, drive in two or three rows of oak or elm piles, which should be scorched in the fire, or half-burnt, before they be driven into the earth ; for being thus used, it preserves them much longer from rotting: and having done so, lay faggots or bavins of smaller wood betwixt them, and then earth betwixt and above them, and then having first very well rammed them and the earth, use another pile in like manner as the first were : and note, that the second pile is to be of or about the height that you intend. to make your sluice or flood-gate, or the vent that you intend shall convey the overflowings of your pond in any flood that shall endanger the breaking of the pond-dam.

Then he advises, that you plant willows or owlers aboutit, or both, and then cast in bavins in some places, not far from. the side, and in the most sandy places, for fish both to spawn upon, and to defend them and the young fry from the many fish, and also from vermin that lie at watch to destroy them, especially the spawn of the carp and tench, when 'tis left to the mercy of ducks or vermin.

$\mathrm{He}$ and Dubravius, and all others advise, that you make choice of such a place for your pond, that it may be refreshed with a little rill, or with rain-water, running or falling into it; by which, fish are more inclined both to breed, and are also refreshed and fed the better, and do prove to be of a much sweeter and more pleasant taste.

* This book, translated into English by Richard Surflet, and corrected by Gervase Markham, is extant, under the title of "The Country Farm." London, 1616 , folio. 
To which end it is observed, that such pools as be large, and have most gravel and shallows where fish may sport themselves, do afford fish of the purest taste. And note, that in all pools, it is best for fish to have some retiring place; as namely, hollow banks, or shelves, or roots of trees, to keep them from danger; and when they think fit, from the extreme heat of the summer; as also, from the extremity of cold in winter. And note, that if many trees be growing about your pond, the leaves thereof, falling into the water, make it nauseous to the fish, and the fish to be so to the eater of it.

'Tis noted that the tench and eel love mud : and the carp loves gravelly ground, and in the hot months to feed on grass. You are to cleanse your pond, if you intend either profit or pleasure, once every three or four years (especially some ponds), and then let it lie dry six or twelve months, both to kill the water-weeds, as water-lilies, candocks, reate, and bulrushes, that breed there; and also that as these die for want of water, so grass may grow in the pond's bottom, which carps will eat greedily in all the hot months, if the pond be clean. The letting your pond dry, and sowing oats in the bottom, is also goo $d$, for the fish feed the faster : and being sometimes let dry, you may observe what kind of fish either increases or thrives best in that water ; for they differ much, both in their breeding and feeding.

Leba ult also advises, that if your ponds be not very large and ro omy, that you often feed your fish by throwing into them chippings of bread, curds, grains, or the entrails of chicke ns or of any fowl or beast that you kill to feed yourselves; for these afford fish a great relief. He says, that frogs and ducks do much harm, and devour both the spawn and the young fry of all fish, especially of the carp ; and I have, kesides experience, many testimonies of it. But Lebault allow s water-frogs to be good meat, especially in some montlis, if the $y$ be fat: but you are to note, that he is a Frenchman; and we English will hardly believe him, though we know frogs are usually eaten in his country: however, he advises to d e stroy them and lking-fishers out of your ponds. And he adv is es not to suffer much shooting at wild fowl; for that, he says, affrightens and harms and destroys the fish.

$\mathrm{N}$ ote, that carps and tench thrive and breed best when no other fish is put with them into the same pond; for all other fish devour their spawn, or at least the greatest part of it. 
And note, that clods of grass thrown into any pond, feed any carps in summer; and that garden-earth and parsley thrown into a pond recovers and refreshes the sick fish. And note, that when you store your pond, you are to put into it two or three melters for one spawner, if you put them into a breeding pond; but if into a nurse-pond or feeding pond, in which they will not breed, then no care is to be taken, whether there be most male or female carps.

It is observed, that the best ponds to breed carps are those that be stony or sandy, and are warm and free from wind, and that are not deep, but have willow trees and grass on their sides, over which the water sometimes flows : and note, that carps do more usually breed in marle-pits, or pits that have clean clay-bottoms, or in new ponds, or ponds that lie dry a winter season, than in old ponds that be full of mud and weeds.

Well, scholar, I have told you the substance of all that either observation, or discourse, or a diligent survey of Dubravius and Lebault hath told me : not that they in their long discourses have not said more ; but the most of the rest are so common observations, as if a man should tell a good arithmetician, that twice two is four. I will therefore put an end to this discourse, and we will here sit down and rest us.*

[Mr. Gottlieb Boccius is one of the best practical breeders of river-fish amongst us. He has written a "Treatise on River-Fish," from which, with his permission, I make the following extracts :-

"THE PoNDS OR STEWS.-These ought to be three in number, and it is requisite to make choice of a slight elevation for the first pond. If

* It is observable that the author has said very little of pond-fishing, which is, in truth, a dull recreation; and to which I have heard it objected, that fish in ponds are already caught. Nevertheless $I$ find, that in the canal at St. James's Park, which, thougl a large one, is yet a pond, it was, in the reign of Charles II., the practice of ladies to angle.

\footnotetext{
"Beneath, a shoal of silver fishes glides, And plays about the gilded barges' sides; The ladies, angling in the crystal lake, Feast on the waters with the prey they take: At once victorious with their lines and eyes, They make the fishes and the men their prize."
}

-Waller, "Poem on St. James's Park," lately improved hy His Majesty.-H.

[Pond-fishing is not now " a dull recreation." The very best bottom-fishing and trolling for pike are, at the present day, to be had in our ponds and reservoirs. Nor is it at all correct to say, "that fish in ponds are already caught"; for instance, to catch carp with rod and line is an angling feat very difficult to perform.-ED.] 
possible this should be so situated that it may receive the drainings of a village, or at any rate proximity to a farm is desirable, as all the refuse washings from such places supply food to a large extent.

"The object in having the first pond higher than the others, is that a supply of water may pass from it to the lower ones in succession: the ponds being connected by a water-course and protected by flood-gates, must have sufficient depth and descent to allow the whole of the water to pass off readily to the next in succession.

"The ponds ought not to be nearer to each other than one hundred yards : the greater the distance between them the better, as each can then have the benefit of the refuse washings of the neighbourhood and adjoining fields, which will of course contribute largely to the support of the stock. Moreover, by having a long water-course between the ponds, when either of them is sluiced off, or as the term is ' fished,' that part of the store, which invariably escapes with the fall of water, can be recovered in a much cleaner and consequently more healthy state than those which are left behind in the slam or mud.

"Clay soils are not genial to fish; therefore light loamy or gravelly bottoms ought to be chosen for the ponds; if, however, the clay is not too deep, and by excavating it yellow sand can be reached, then it will leave an equally soft and pure bottom, the sides being of less importance.

"In clay bottoms the fish do not thrive, from want of food, in consequence of the water partaking of the racy* quality of the earth, which from its cold and sterile nature does not afford the nutriment requisite for the maintenance of the larvæ of insects, worms, and other minute living creatures, in sufficient number, and so keeps the stock lean and unfit for food.

"In forming ponds, particular care ought to be taken to make the sides shelve gradually for about six yards; and they are on no account to be deep at the sides, firstly, on account of the sward nourishing large quantities of insects, etc., the legitimate food of the fish ; secondly, the ponds are not so easily poached, the shallows being protected by stakes; and thirdly, protection is afforded to the brood.

"The only deep that ought to exist at either side should be near the sluice or floodgate, where it should be twelve or eighteen inches deeper than the rest of the pond, in order that when the water is drawn off, the fish may be collected into a close space, and when the sluice is again closed, an accumulation of water may immediately take place, sufficient for the protection of the brood or succeeding store.

"In the rainy season it is always advisable to let the ponds fill to the full extent of their prescribed boundaries, as this not only brings a large proportion of food from the adjacent grounds, but when the water is again let off or recedes, the borders produce luxuriant and tender herbage, peculiarly adapted for the food of carp, and upon which that fish feeds greedily in rainy weather, and may frequently be observed flounder-

* Racy is the term for a species of iron-stone sand found in clay strata. 
ing half out of his watery element in order to obtain his favourite morsel.

"As all foliage is pernicions, and the decomposition highly injurious to fish, especially to the fry or brood, it must be fully borne in mind that trees or shrubs should never be planted on the borders or margins of the ponds ; but if ornament be required, then only at a sufficient distance, for it is equally necessary to have a free action of air passing over the surface, as it is to have pure and wholesome water, in fact the removal of trees contributes largely to effect both.

"Fish grown by these directions will not only prove fat, but of a far superior flavour to those taken from common and ill-regulated ponds or stews.

"If the first pond should get an over-accumulated store of water, it must be let off by the sluice into the second, and so on to the third, and then be suffered to run waste, for no pond onght on any account to overflow or break its boundaries, as by so doing and by conveying the fish to the next pond, it injures that stew by introducing fish of different growths, and so proves ultimately a serious loss; food would be then insufficient for their joint maintenance, consequently the fish would gain but little in size and weight.

"If the ponds have an even and well-regulated supply of water, then their depth at the centre need never be more than from three to five feet, shelving to the sides as before stated; but if only an indifferent supply can be obtained, then they must be twelve or eighteen incles deeper.

"It is not, however, desirable to have the ponds so situated that a large quantity of fresh water shall suddenly be able to find its way into them, as it both thickens the whole by moving the mud, and being colder and of other properties, it sickens the store for some time, and checks their thriving. A well-regulated supply and co-equal discharge is to be recommended and must be attended to.

"Having thus far described the base and positions which the ponds ought to have, I shall proceed to lay down the requisite rules, by attention to which a lucrative rental can be obtained, where an estate is adapted for succession ponds. The first pond should be the smallest of the three, the second next in size, and the third the largest, for the following reasons. At the period of fishing, as before stated, a great portion of the brood escapes with the flood, which cannot be prevented; and as another year must elapse before the water or ponds in succession can be fished, too much of the food of the original store would be consumed were not the second pond larger, and so capable of receiving the addition; it would moreover prove extremely detrimental, as I shall afterwards show.

"In order to come to the dimensions of the ponds I shall propose the following scale :-No. 1, three acres; No. 2, four acres; No. 3, five acres; making altogether twelve acres of water, which, after the first three years of their stores, will produce an annual income from each pond in rotation.

"To stock the ponds with brood, the following simple calculation is sufticient for direction; viz., to every acre of water in extent, put in 200 
brood carp, 20 brood tench, and 20 brood jack; thus making 10 per cent. each of tench and jack to the carp; the brood must be all of one season's spawn. Therefore to three acres there will be $600 \mathrm{carp}, 60$ tench, and 60 jack, and the succession ponds are to be stocked in like proportions, the second the year following the first, and the third again a year later, so that each pond then comes round in its turn to be fished. . . . .

"In stocking ponds it must be strictly observed that the jack, carp, and tench be all of the same season or spring spawn; and the period for brooding the pond is towards the end of October, or if the season be open and mild, early in November, for the following reasons. Carp and tench being fish of the same habits, they slam or mud at the same period, lying torpid through the winter months, so that they keep secure from the attacks of the juvenile jack; the jack at that age finds sufficient food in worms, etc., to subsist upon: as the spring advances, when the carp and tench leave their winter lairs, the jack then in turn become sickly as their spawning season approaches, and consequently do not annoy the carp, much less the tench; this brings them through April, when the jack spawn, and they remain quiet from that time until the wet season in July.

"In June both the carp and tench spawn, and although in very small casts for the first season, yet they are far larger than would be beneficial for the stews were no jack in them; and from this period the jack becomes useful, for as he gets more and more vigorous, so does he keep) down the brood and thrive himself: thus by making an easy prey, it seldom if ever occurs that a jack chases a carp of his own age ; the result is, that through the clearance of the brood the stock finds sufficient food to live and thrive upon.

"There are two species of weeds which are requisite in your ponds, and on which carp and tench spawn; the one is Potamogeton natans, or broad-leaved pond-weed, sometimes called tench-weed; the other is Ranunculus aquatilis or water crow-foot. Against the former, during the period of casting their spawn, they rub themselves, either from an exciting or soothing cause, but they invariably discharge the ova on the crow-foot, which is a long wiry weed, forming at intervals circles of fine leaves : from its toughness and close foliage it protects the spawn and young fry from the attacks of birds of prey. I think it is by means of this weed that wild fowl convey different species of fish from one pond to another, in consequence of the gelatinous nature of the oya causing them to adhere to the feathers of the bird while feeding, and this will account for fish being found in waters where none of the sort had been stored. Wild fowl are particularly fond of spawn; they destroy much of it, and seek the weeds encumbered with it. It is among these weeds that the fry are partially protected when they emerge from the ova; for like everything produced from creation's lot, in the early stage of life being perfectly helpless, so do they swim, or more properly, float about, for three or four days with the shell of the ova attached to them, showing a similarity to the umbilical cord in animals, after which it falls off, and then the brood instinctively move in a shoal to the scours, for the protection against other fish afforded by the shallow water, as well as on account of 
its being warmer and of lighter weight to their small frames. It is during the first movement from the egg that fish of prey, especially eels, are so destructive to the spawn-casts; and I have seen a male trout trailing over and around the layer, open-mouthed, hunting away every other fish that should make its appearance, solely to gratify his voracious appetite. To a casual observer it would appear as if he protected the fry, but this is not the case, as he does not even permit the spawner to approach; and were protection the object, every trout stream would be swarming with millions of fry, whereas it is difficult to keep a trout stream in a tolerably wellstocked state."]

\section{CHAPTER XXI.}

DIRECTIONS FOR MAKING OF A LINE, AND FOR THE COLOURING

OF BOTH ROD AND LINE.

\section{[fifth (last) 四an.]}

Pisc. Well, scholar, I have held you too long about these cadis, and smaller fish, and rivers, and fish-ponds; and my spirits are almost spent, and so I doubt is your patience : but being, we are now almost at Tottenham, where I first met you, and where we are to part, I will lose no time, but give you a little direction how to make and order your lines, and to colour the hair of which you make your lines, for that is very needful to be known of an angler ; and also how to paint your rod, especially your top; for a right grown top is a choice commodity, and should be preserved from the water soaking into it, which makes it in wet weather to be heavy and fish ill-favouredly, and not true ; and also it rots quickly for want of painting: and I think a good top is worth preserving, or I had not taken care to keep a top above twenty years.

But first for your line. First, note, that you are to take care that your hair be round and clear, and free from galls or scabs or frets, for a well-chosen, even, clear, round hair, of a kind of glass-colour, will prove as strong as three uneven scabby hairs, that are ill-chosen, and full of galls or unevenness. You shall seldom find a black hair but it is round, but many white, are flat and uneven; therefore, if you get a lock of right, round, clear, glass-colour hair, make much of it.

And for making your line observe this rule ; first let your 
hair be clean washed ere you go about to twist it; and then choose not only the clearest hair for it, but hairs that be of an equal bigness, for such do usually stretch altogether, and break altogether, which hairs of an unequal bigness never do, but break singly, and so deceives the angler that trusts to them.

When you have twisted your links, lay them in water for a quarter of an hour at least, and then twist them over again, before you tie them into a line: for those that do not so, shall usually find their line to have a hair or two shirink, and be shorter than the rest at the first fishing with it, which is so much of the strength of the line lost for want of first watering it and then re-twisting it; and this is most visible in a sevenhair line, one of those which hath always a black hair in the middle.

And for dyeing of your hairs, do it thus : take a pint of strong ale, half a pound of soot, aud a little quantity of the juice of walnut-tree leaves, and an equal quantity of alum ; put these together, in a pot, pan, or pipkin, and boil them half an hour; and having so done, let it cool; and being cold, put your hair into it, and there let it lie; it will turn your hair to be a kind of water or glass-colour, or greenish; and the longer you let it lie the deeper it will be. You might be taught to make many other colours, but it is to little purpose; for doubtless the water-colour or glass-coloured hair is the most choice or the most useful for an angler, but let it not be too green.

But if you desire to colour hair greener, then do it thus : take a quart of small ale, half a pound of alum; then put these into a pan or pipkin, and your hair into it with them; then put it upon a fire, and let it boil softly for half an hour; and then take out your hair, and let it dry; and having so done, then take a pottle of water, and put into it two handfuls of marigolds, and cover it with a tile or what you think fit, and set it again on the fire, where it is to boil again softly for half an hour, about which time the scum will turn yellow; then put into it half a pound of copperas, beaten small, and with it the hair that you intend to colour; then let the hair be boiled softly till half the liquor be wasted, and then let it cool three or four hours with your hair in it; and you are to observe that the more copperas you put into it, the greener it will be ; but, doubtless, the pále green is best : but if you desire yellow hair, which is only good when the weeds rot, 
then put in the more marigolds, and abate most of the copperas, or leave it quite out, and take a little verdigrease instead of it.

This for colouring your hair. And as for painting your rod, which must be in oil, you must first make a size with glue and water, boiled together until the glue be dissolved, and the size of a lye-colour; then strike your size upon the wood with a bristle, or a brush, or pencil, whilst it is hot; that being quite dry, take white-lead, and a little red-lead, and a little coal-black, so much as altogether will make an ash-colour; grind these all together with linseed oil; let it be thick, and lay it thin upon the wood with a brush or pencil; this do for the ground of any colour to lie upon wood.

For a green, take pink and verdigrease, and grind them together in linseed-oil, as thin as you can well grind it; then lay it smoothly on with your brush, and drive it thin; once doing, for the most part will serve, if you lay it well; and if twice, be sure your first colour be thoroughly dry before you lay on a second.

Well, scholar, having now taught you to paint your rod, and we having still a mile to Tottenham High-cross, I will, as we walk towards it in the cool shade of this sweet honeysuckle hedge, mention to you some of the thoughts and joys that have possest my soul since we two met together. And these thoughts have been told you, that you may also join with me in thankfulness to the Giver of every good and perfect gift, for our happiness. And that our present happiness may appear to be the greater, and we the more thankful for it, I will beg you to consider with me, how many do, even at this very time lie under the torment of the stone, the gout, and tooth-ache; and this we are free from. And every misery that I miss is a new mercy, and therefore let us be thankful. There have been, since we met, others that have met disasters of broken limbs; sume have been blasted, others thunderstrucken; and we have been freed from these, and all those many other miseries that threaten human nature; let us therefore rejoice, and be thankful. Nay, which is a far greater mercy, we are free from the unsupportable burthen of an accusing tormenting conscience, a misery that none can bear; and therefore let us praise him for his preventing grace, and say, every misery that I miss is a new mercy: nay, let me tell you, there be many that have forty times our. estates, that would give the greatest part of it to be healthful 
and cheerful like us; who, with the expence of a little money, have eat and drank, and laught, and angled, and sung, and slept securely; and rose next day, and cast away care, and sung, and laught, and angled again ; which are blessings rich men cannot purchase with all their money. Let me tell you, seholar, I have a rich neighbour that is always so busy that he has no leisure to laugh; the whole business of his life is to get money, and more money, that he may still get more and more money; he is still drudging on, and says, that Solomon says, "The diligent hand maketh rich:" and it is true indeed; but, he considers not that it is not in the power of riches to make a man happy: for it was wisely said, by a man of great observation, "That there be as many miseries beyond riches, as on this side them:" and yet God deliver us from pinching poverty ; and grant that having a competency, we may be content, and thankful. Let us not repine, or so much as think the gifts of God unequally dealt, if we see another abound with riches, when, as God knows, the cares that are the keys that keep those riches hang often so heavily at the rich man's girdle, that they $\mathrm{clog}$ him with weary days and restless nights, even when others sleep quietly. We see but the outside of the rich man's happiness : few consider him to be like the silk-worm, that, when she seems to play, is, at the very same time, spinning her own bowels, and consuming herself; and this many rich men do, loading themselves with corroding cares, to keep what they have, probably, unconscionably got. Let us, therefore, be thankful for health and a competence ; and, above all, for a quiet conscience.

Let me tell you, scholar, that Diogenes walked on a day, with his friend, to see a country fair; where he saw ribbons and looking-glasses and nut-crackers and fiddles and hobbyhorses and many other gimcracks; and, having observed them and all the other finnimbruns that make a complete country fair, he said to his friend, "Lord, how many things are there in this world of which Diogeneshath no need !" And truly it is so, or might be so, with very many who vex and toil themselves to get what they have no need of. Can any man charge God that he hath not given him enough to make his life happy? No, doubtless; for nature is content with a little. And yet you shall hardly meet with a man that complains not of some want; though he, indeed, wants nothing but his will; it may be, nothing but his will of his poor neighbour, for not worshipping or not flattering him: and thus when we might 
be happy and quiet, we create trouble to ourselves. I have heard of a man that was angry with himself because he was no taller; and of a woman that broke her looking-glass because it would not show her face to be as young and handsomeas her next neighbour's was. And Iknew another to whom God had given health and plenty, but a wife that nature had made peevish, and her husband's riches had made purse-proud; and must, because she was rich, and for no other virtue, sit in the highest pew in the church; which being denied her, she engaged her husband into a contention for it, and at last into a law-suit with a dogred neighbour who was as rich as he, and had a wife as peevish and purse-proud as the other: and this law-suit begot higher oppositions, and actionable words, and more vexations and law-suits ; for you must remember that both were rich, and must therefore have their will. Well, this wilful, purse-proud law-suit lasted during the life of the first husband; after which his wife vext and chid, and chid and vext till she also chid and vext herself into her grave : and so the wealth of these poor rich people was curst into a punishment, because they wanted meek and thankful hearts; for those only can make us happy. I knew a man that had health and riches, and several houses, all beautiful, and ready furnished, and would often trouble himself and family, to be removing from one house to another; and being asked by a friend, why he removed so often from one house to anotlier, replied, "It was to find content in some one of them." But his friend, knowing his temper, told him, If he would find content in any of his houses he must leave himself behind him; for content will never dwell but in a meek and quiet soul. And this may appear, if we read and consider what our Saviour says in St. Matthew's gospel ; for he there says,_- " Blessed be the merciful, for they shall obtain mercy.-Blessed be the pure in heart, for they shall see God.-Blessed be the poor in spirit, for theirs is the kingdom of heaven." And, "Blessed be the meek, for they shall possess the earth." Not that the meek shall not also obtain mercy, and see God, and be comforted, and at last come to the kingdom of heaven; but in the mean time he, and he only, possesses the earth, as he goes towards that kingdom of heaven, by being humble and cheerful, and content with what his good God has allotted him. He has no turbulent, repining, vexatious thoughts that he deserves better; nor is vext when he sees other's possest of more honour or more riches P 2 
than his wise God has allotted for his share; but he possesses what he has with a meek and contented quietness, such a quietness as makes his very dreams pleasing, both to God and himself.

My honest scholar, all this is told to incline you to thankfulness; and to incline you the more, let me tell you, that though the prophet David was guilty of murder and adultery, and many other of the most deadly sins, yet he was said to be a man after God's own heart, because he abounded more with thankfulness than any other that is mentioned in holy Scripture, as may appear in his book of Psalms; where there is such a commixture of his confessing of his sins and unworthiness, and such thankfulness for God's pardon and mercies, as did make him to be accounted, even by God himself, to be a man after his own heart : and let us, in that, labour to be as like him as we can; let not the blessings we receive daily from God make us not to value or not praise him because they be common; let us not forget to praise him for the innocent mirth and pleasure we have met with since we met together. What would a blind man give to see the pleasant rivers and meadows and flowers and fountains that we have met with since we met together? I have been told, that if a man that was born blind could obtain to have his sight for but only one hour during his whole life, and should, at the first opening of his eyes, fix his sight upon the sun when it was in its full glory, either at the rising or setting of it, he would be so transported and amazed, and so admire the glory of it, that he would not willingly turn his eyes from that first ravishing ohject, to behold all the other various beauties this world could present to him. And this, and many other like blessings, we enjoy daily. And for most of them, because they be so cornmon, most men forget to pay their praises : but let not us, because it is a sacrifice so pleasing to Him that made that sun and us, and still protects us, and gives us flowers and showers, and stomachs and meat, and content and leisure to go a-fishing.

Well, scholar, I have almost tired myself, and, I fear, more than almost tired you; but I now see Tottenham High-cross, and our short walk thither shall put a period to my too long discourse, in which my meaning was and is, to plant that in your mind, with which I labour to possess my own soul: that is, a meek and thankful heart. And to that end, I have -showed you that riches, without them, do not make any man 
happy. But let me tell you, that riches, with them, remove many fears and cares ; and therefore my advice is, that you endeavour to be honestly rich, or contentedly poor : but be sure that your riches be justly got, or you spoil all. For it is well said by Caussin," "he that loses his conscience, has nothing left that is worth keeping." Therefore be sure you look to that. And, in the next place, look to your health : and if you have it, praise God, and value it next to a good conscience; for health is the second blessing that we mortals are capable of ; a blessing that money cannot buy, and therefore value it, and be thankful for it. As for money, which may be said to be the third blessing, neglect it not : but note, that there is no necessity of being rich; for I told you there be as many miseries beyond riches, as on this side them : and if you have a competence, enjoy it with a meek, cheerful, thankful heart. I will tell you, scholar, I have heard a grave divinet say, that God has two dwellings, one in heaven, and the other in a meek and thankful heart. Which Almighty God grant to me, and to my honest scholar : and so you are welcome to Tottenham High-cross.

VEN. Well, master, I thank you for all your good directions; but for none more than this last, of thankfulness, which I hope I shall never forget. And $^{+}$pray let's now rest

* Nicholas Caussin, a native of Troyes, in Champagne, wrote a book called "The Holy Court," of which there is an English translation in folio. He was esteemed a person of great probity, and of such a spirit, that he attempted to displace Cardinal Richelieu; but that minister proved too hard for him, and got lim banished. The sentiment above quoted from him is worthy of Marcus Antoninus, or, if that be not enough to say, of Dr. Jeremy Taylor himself.-H.

$\dagger$ Dr. Donne, as a reverend and learned friend of mine informs me.-H.

‡ The four preceding paragraphs beginning with, "Well, scholar," etc., deserve most attentive perusal. They are entirely worthy of the excellent man who styles angling the "Contemplative Man's Recreation." See how frequently and sincerely he urges upon us meekness and thankfulness-the former towards man, the latter towards God. Cheerfulness, contentment health, a quiet guileless conscience, are in his eyes the greatest of mundane possessions. He says, " every misery that I miss is a new mercy. Nay, let me tell you, there be many that have forty times our estates, that would give the greatest part of it to be healthful and cheerful like us; who with the expence of a little money, have ate and drank, and laught, and sung, and slept; and rose next day, and cast away care, and sung, and laught, and angled again; which are blessings rich men cannot purchase with all their money." What a genial and more than pretty picture of angling life! In another passage, he says, the meek man "shall obtain mercy, and see God, and be comforted, and at last come to the kingdom of heaven; but in the mean time, he, and he only possesses the earth as he goes toward that kingdom of heaven, by being humble and cheerful, and content with what his good God has allotted him." Again 
ourselves in this sweet shady arbour, which nature herself has woven with her own fine finger; 'tis such a contexture of woodbines, sweetbriar, jessamine, and myrtle ; and so interwoven, as will secure us both from the sun's violent heat and from the approaching shower. And being sat down, I will requite a part of your courtesies with a bottle of sack, milk, oranges, and sugar; which, all put together, make a drink like nectar; indeed, too good for any but us anglers. And so, master, here is a full glass to you of that liquor: and when you have pledged me I will repeat the verses which I promised you : it is a copy printed among some of Sir Henry Wotton's, and doubtless made either by him or by a lover of angling. Come, master, now drink a glass to me, and then I will pledge you, and fall to my repetition ; it is a description of such country recreations as I have enjoyed since I had the happiness to fall into your company.

Quivering fears, heart-tearing cares,

Anxious sighs, untimely tears,

Fly, fly to courts,

Fly to fond worldlings' sports,

Where strain'd Sardonic smiles are glosing still,

And grief is forced to laugh against her will :

Where mirth's but mummery,

And sorrows only real be.

Fly from our country's pastimes, fly,

Sad troops of human misery.

Come, serene looks,

Clear as the crystal brooks,

Or the pure azured heaven that smiles to see

The rich attendance on our poverty ;

Peace and a secure mind,

Which all men seek, we only find.

he says, "And for most of them (the beauties of external nature), because they are so common, most men forget to pay their praises; but let not us; because it is a sacrifice so pleasing to him that made that sun and us, and still protects us, and gives us flowers, and showers, and stomachs, and meat, and content, and leisure to go a-fishing." After exhibiting a moral and pious philosophy, he descends to the practical; writing,- "Health is the second blessing that we mortals are capable of; a blessing that money cannot buy ; and therefore value it, and be thankful for it. As for money, which may be said to be the third blessing, neglect it not : but note, that there is no necessity for being rich : for I told you, there be as many miseries beyond riches as on this side of them: and if you have a competence, enjoy it with a meek, cheerful, thankful heart." Good and wise old man! It was you whom a great and reckless poet designated "a quaint old cruel coxcomb!" Never did a more flagrant misnomer proceed from the nomenclature of a vexed and discontented spirit. Here it is no longer "crede Byron"!-ED. 
Abused mortals! did you know

Where joy, heart's ease, and comforts grow,

You'd scorn proud towers,

And seek them in these bowers;

Where winds, sometimes, our woods perhaps may shake,

But blustering care could never tempest make,

Nor murmurs e'er come nigh us,

Saving of fountains that glide by us.

Here's no fantastic mask nor dance,

But of our kids that frisk and prance ;

Nor wars are seen,

Unless upon the green

Two harmless lambs are butting one the other-

Which done, both bleating run, each to his mother;

And wounds are never found,

Save what the ploughshare gives the ground.

Here are no entrapping baits,

To hasten to too hasty fates,

Unless it be

The fond credulity

Of silly fish, which (worldling like) still look

Upon the bait, but never on the hook ;

Nor envy, less among

The birds, for prize of their sweet song.

Go, let the diving negro seek

For gems, hid in some forlorn creek :

We all pearls scorn,

Save what the dewy morn

Congeals upon each little spire of grass,

Which careless shepherds beat down as they pass ;

And gold ne'er here appears,

Save what the yellow Ceres bears.

Bless'd silent groves, 0 may you be,

For ever, mirth's best nursery !

May pure contents

For ever pitch their tents

Upon these downs, these meads, these rocks, these mountains,

And peace still slumber by these purling fountains ;

Which we may every year

Meet, when we come a-fishing here!

Pisc. Trust me, scholar, I thank you heartily for these verses : they be choicely good, and doubtless made by a lover of angling. Come, now, drink a glass with me, and I will requite you with another very good copy: it is a farewell to the vanities of the world, and some say written by Sir Harry Wotton, who I told you was an excellent angler: But let them be writ by whom they will, he that writ them had a brave soul, and must needs be possessed with happy thoughts at the time of their composure. 
Farewell, ye gilded follies, pleasing troubles !

Farewell, ye honour'd rags, ye glorious bubbles !

Fame's but a hollow echo-gold, pure clay-

Honour, the darling but of one short day-

Beauty, th' eye's idol, but a damask'd skin-

State, but a golden prison, to live in,

And torture free-born minds-embroider'd trains,

Merely but pageants for proud swelling veins-

And blood allied to greatress is alone

Inherited, not purchased, nor our own.

Fame, honour, beauty, state, train, blood, and birth,

Are but the fading blossoms of the earth.

I would be great, but that the sun doth still

Level his rays against the rising hill-

I would be high, but see the proudest oak

Most subject to the rending thunder-stroke-

I would be rich, but see men (too unkind)

Dig in the bowels of the richest mind-

I would be wise, but that I often see

The fox suspected, whilst the ass goes free-

I would be fair, but see the fair and proud,

Like the bright sun, oft setting in a cloud-

I would be poor, but know the humble grass

Still trampled on by each unworthy ass-

Rich, hated-wise, suspected-scorn'd, if poor-

Great, fear'd-fair, tempted-high, still envied more :

I have wish'd all ; but now I wish for neither,

Great, high, rich, wise, nor fair-poor I'll be rather.

Would the world now adopt me for her heir-

Would beauty's queen entitle me the fair-

Fame speak me fortune's minion-could I vie

Angels with India* - with a speaking eye

Command bare heads, bow'd knees, strike justice dumb,

As well as blind and lame, or give a tongue

To stones by epitaphs-be call'd "great master,"

In the loose rhymes of every poetaster-

Could I be more than any man that lives,

Great, fair, rich, wise, all in superlatives-

Yet I more freely would these gifis resign,

Than ever Fortune would have made them mine ;

And hold one minute of this holy leisure

Beyond the riches of this empty pleasure !

* An angel is a piece of coin, value ten shillings. The words to vie angels, are a periphrasis, and signify to compare wealth. In the old ballad of the Beggar's Daughter of Bethnal-green, a competition of this kind is introduced : a young knight, about to marry the beggar's daughter, is dissuaded from so unequal a match by some gentlemen, his relations, who urge the poverty of her father : the beggar challenges them to drop angels with him, and fairly empties the purses of them all. The contest, and its issue, are related in the wellknown ballad beginning,-

"Then spake the blind beggar, "Although I be poore,

Yett rayle not against my child at my own door :

Though shee be no decked in velvet and pearle,

Yett I will dropp angells with you for my girle." "-H. 
Welcome, pure thoughts ! welcome, ye silent groves !

These guests, these courts, my soul most dearly loves !

Now the wing'd people of the sky shall sing

My cheerful anthems to the gladsome spring :

A prayer-book, now, shall be my looking-glass,

In which I will adore sweet virtue's face.

Here dwell no hateful looks, no palace cares,

No broken vows dwell here, nor pale-faced fears;

Then here I'll sit, and sigh my hot love's folly,

And learn t' affect a holy melancholy :

And if contentment be a stranger, - then

I'll ne'er look for it, but in heaven, again.

VEN. Well, master, these verses be worthy to keep a room in every man's memory. I. thank you for them; and I thank you for your many instructions, which (God willing) I will not forget. And as St. Austin, in his "Confessions" (book iv. chap. 3) commemorates the kindness of his friend Verecundus, for lending him and his companion a country house ; because there they rested and enjoyed themselves, free from the troubles of the world: so, having had the like advantage, both by your conversation and the art you have taught me, I ought ever to do the like; for indeed, your company and discourse have been so useful and pleasant, that, I may truly say, I have only lived since I enjoyed them and turned angler, and not before. Nevertheless, here I must part with you, here in this now sad place where I was so happy as first to meet you : but I shall long for the ninth of May; for then I hope again to enjoy your beloved company, at the appointed time and place. And now I wish for some somniferous potion, that might force me to sleep away the intermitted time, which will pass away with me as tediously, as it does with men in sorrow; nevertheless, I will make it as short as I can by ny hopes and wishes. And, my good master, I will not forget the doctrine which you told me Socrates taught his scholars, that they should not think to be honoured so much for being philosophers, as to honour philosophy by their virtuous lives. You advised me to the like concerning angling, and I will endeavour to do so; and to live like those many worthy men of which you made mention in the former part of your discourse. This is my firm resolution; and as a pious man advised his friend, that to beget mortification he should frequent churches, and view monuments, and charnel-houses, and then and there consider, how many dead bodies time had piled up at the gates of death: so when I would beget content, and increase confidence in the power, and wisdom, 
and providence of Almighty God, I will walk the meadows by some gliding stream, and there contemplate the lilies that take no care, and those very many other various little living creatures, that are not only created but fed, man knows not how, by the goodness of the Grod of nature, and therefore trust in him. This is my purpose ; and so, let everything that hath breath praise the Lord: and let the blessing of St. Peter's master be with mine.

PIsc. And upon all that are lovers of virtue, and dare trust in his providence, and be quiet, and go a-angling.

+ "Study to be Quiet."-1 Thess. iv. 11.

[The concluding chapter of Walton contains a few brief " directions for making of a line, and for the colouring of both rod and line." These directions are of no value now. Walton's lines would neither suit the modern winch, nor make a proper foot line, except for fishing in flooded and discoloured waters. Winch-lines are now made by professed makers, who sell them to the proprietors of fishing-tackle shops, and by the latter they are retailed to the public. These lines are either twisted or plaited by means of hand-machines, and no part or parts of them are joined together by tying or knotting. They are uniformly smooth throughout their length, and of uniform thickness, except winch fly-lines, which taper towards one end, and sometimes in the direction of both ends. I am not favourable to tapering lines, except to taper foot ones, and winch-lines for salmon and trout, as now made, run off to too fine an end. The tapering points of them are lighter than the gut, foot, or casting-line, and hence they are an obstacle to throwing to a long distance, and cannot be propelled at all against the wind. Lines for bottom fishing may be made solely of twisted silk, and to preserve them from the destructive effects of water and rain, they should be steeped for a short time in a mixture of the best oil and varnish. Lines for fly-fishing, whether for trout or salmon, should be made of plaited silk and hair, and if they taper at all it should be very slightly. They cannot be plaited too closely, and they should consist of one-third sound picked horsehair, and two-thirds best silk. The best are manufactured by a man named Dodge, in London, and all the great tackle-makers sell them. If you wish to preserve your lines from rotting, never allow them when wet to dry coiled up on your winch, but, the moment you return from fishing, uncoil all the wetted parts of lines, and wind them thinly on the backs of chairs, or let them fall in large coils on any clean spot on which the action of air or heat will reach them.

Winches, reels, or pirns seem to have been unknown in Walton's time. How they managed, particularly in fishing with the artificial fly, or dibbing with the natural one, to lengthen and shorten line is a mystery; and how they could successfully play a large fish is incomprehensible. 'They must have used thumb-winders, or very likely a piece of stick 
fastened to the butt, at some distance from its base, cross-wise. On this stick the line may be wound, just as boys when kite-flying wind their strings; and it may be uncoiled by hand when playing a fish, or wanting more, but not with sufficient rapidity or ease. The best London winches -and to metropolitan made ones I give the preference-are manufactured by Fairservice. I am opposed to multiplying-winches, and prefer to all others a plain, somewhat stiff check one, particularly for salmonfishing. I like to hear the pleasant rattle of its checks, as the fish rattles away, and its stiffness is of great service in keeping the line taut as you play a fish. The clicking, by its frequency or otherwise, tells you at what pace your fish is going, and gives you a notion when you should follow him, or attempt to stop him, to bear upon him, and to work him towards land. Reels of free check, or click, should be used for pikefishing, and for all fish that run to their lairs to pouch their baits. In their run to do so they should not meet with any impediment from a taut or partly taut line, but should be able to swim away with loosened reins.

Of the making and material of rods, Father Walton says nothing, and his instructions about painting them should not be followed. Rods are not now painted. They are stained and washed with varnish. I shall name the lengths which rods for different sorts of fishing should respectively reach, the material they should be made of, and a few of their component qualities.

A single-handed fly-rod for trout and grayling should be made with great eare, and of the best and longest seasoned wood. It should vary from ten to twelve-and-a-half feet in length. The shorter rod for narrow, bright rivers, as it carries fine tackle best, and can be worked with more ease, and consequently make neater and lighter casts; the longer rod is suited for broad and deep trout streams, where stout tackle and large flies are necessary; where the angler must throw the long line, and where he will have to cope with large fish. Indeed, with a well-balanced twelve-foot-and-a-half fly-rod, made of elastic and well-seasoned wood, a proficient can throw the lightest as well as the heaviest line. It is the rod 1 would recommend to the adult angling adept. A fly-rod of eleven feet has the average length, and will not inconveniently suit young and old, and moderately weak and strong hands. Fly-rods should be made of the following materials-best grained and long-seasoned ash for butts, thick and small pieces (second and third joints) best hickory, tops a foot of lance-wood, and thence to the extreme points bamboo cane. If one piece of the rod be made of newer, that is, less seasoned wood than the others, there will be too much dead play in that piece, and the rod will therefore want balance and be defective. If the pieces, particularly the small and the top pieces, do not taper justly, or be heavier or weaker in undue proportion than the thick piece and butt, then the rod will be "top-heavy," and good for nothing. The fittings of each piece should be most carefully adapted - the ferules smoothly polished on the inside, and the tongues and shoulders should be most carefully brased. A firstrate trout fly-rod cannot be bought for less than a guinea and a half.

The grilse fly-rod should be sixteen feet in length, the salmon rod eighteen, and in rare cases, for very tall and strong men, and for great 
rivers and large fish, the length may be twenty feet. My favourite length is seventeen-and-a-half feet, and with it I can pleasantly fish for sea-trout and grilse, and have no fear of the biggest salmon, substituting for the lighter grilse winches and lines, larger and stouter salmon ones. The salmon, like the tront rod, should consist of four pieces, made of wood of similar sorts and qualities. Its balance should be just, and all its fittings most carefully executed. In former writings, I suggested the following improvement in salmon-rods. There slould be no spare top for trolling or spinning, but merely a spare fly top, which should be of bamboo cane rent longitudinally into wedge-shaped pieces. The original position of these pieces should be altered, so as to oppose sound parts to defective ones, to reverse the grain, and to have elastic action in all sides of the top-joint. The pieces should be first glued in, and then tied strongly together for a day or two. The whole should then be rounded and tapered, strongly whipped and ringed. Salmon-rod tops should not taper to a fine point, and their last ring should not be of brass wire, but of hollowed and smooth steel, projecting upwards like the other rings. Such a spare top should be reserved for heavy work in rivers, in and over which there are rocks and trees, rendering the playing of a fish more than ordinarily difficult, and tackle of more than common strength necessary.

Trolling-rods shonld not be longer than eleven feet; spinning ones not more than fifteen. They should be of the same materials as those already named. The preference now is given to East India mottled or burnt cane, for all the pieces except the top one, and that should be of lance-wood and bamboo-cane. The pieces of the trolling-rod should be very stout, with a few very large and upright rings. The pieces of the spinning-rod should be moderately stout-something between those of the trolling-rod and the larger trout fly-rod-and they should be ringed with middle-sized upright rings, and should be tolerably elastic.

The roach-rod should be, for bank-fishing, eighteen or twenty feet in length. All its pieces should be of the lightest white Spanish or Honduras cane, except the top, which should be fine and light and elastic and of bamboo-cane. The roach-rod for boat-fishing should be of the same material, but not more than twelve feet long.

The ordinary bottom-rod for bank-fishing should be sixteen feet in length, of ash, hickory, and bamboo. It should resemble a grilse fly-rod, but be a little less "whippy" or elastic. The boat bottom-rod for barbel, chub, \&c., should be eleven or twelve feet in length, of the same materials as the last, but of stouter and stiffer build. I am not favourable to what are called "general rods," or "walking-cane" rods, and therefore shall say nothing further about them.

The trout and salmon rods, and trout and salmon flies I fish with, are made by Blacker. The purchaser, however, must "try conclusions," as Walton says in his chapter on barbel fishing, that is, make experiments; and in selecting angling apparatus, I advise that he try his conclusions at the following largely stocked angling arsenals : to wit, those of Messrs. Alfred, Moorgate-street; Ainge and Aldred, Oxford-street; Anderson, 
Long Acre; Barnard, Church-place, Piccadilly ; Bowness, Bell-yard, Temple-bar; Cheek, Oxford-street; Charles Farlow, 121, Strand; J. Farlow, Crooked-lane, London-bridge; Gould, Great Marylebone-street, Cavendish-square; Jones, Jermyn-street; and last, but by no means least, Giles Little, rod-maker to H.R.H. Prince Albert, 15, Fetter-lane. -ED.] 



\section{THE}

\section{COMPLETE ANGLER.}

\section{PART II.}

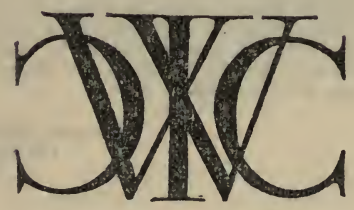

BEING INSTRUCTIONS

HOW TO ANGLE FOR A TROUT OR GRAYLING

IN A CLEAR STREAM.

Qui mili non credit, faciat licct ipse periclum:

Et fuerit scriptis æquior ille meis. 


\section{MR. IZAAK WALTON, THE ELDER.}

Sir,-Being you were pleased, some years past, to grant me your free leave to do what I have here attempted; and observing you never retract any promise when made in favour of your meanest friends; I aceordingly expect to see these following particular directions for the taking of a trout, to wait upon your better and more general rules for all sorts of angling. And though mine be neither so perfect, so well digested, nor indeed so handsomely couch'd as they might have been, in so long a time as since your leave was granted, yet I dare affirm them to be generally true: and they had appeared too in something a neater dress, but that I was surprised with the sudden news of a sudden new edition of your " Complete Angler;" so that, having little more than ten days' time to turn me in, and rub up my memory (for, in truth, I have not, in all this long time, though I have often thought on't, and almost as often resolved to go presently about it), I was foreed, upon the instant, to seribble what I here present you: which I have also endeavoured to accommodate to your own method. And, if mine be elear enough for the honest brothers of the angle readily to understand, which is the only thing I aim at, then I have my end, and shall need to make no further apology; a writing of this kind not requiring, if I were master of any such thing, any eloquence to set it off, and recommend it; so that if you, in your better judgment, or kinduess rather, can allow it passable for a thing of this nature, you will then do me the honour if the cypher fixed and carved in the front of my little fishinghouse, may be here explained: and to permit me to attend you in public, who, in private have ever been, am, and ever resolve to be,

Beresford,

10th of March, 1675-6.
Sir,

Your most affectionate son and servant, CHARLES COTTON.

\footnotetext{
.

To

MY MOST HONOURED FRIEND,

CHARLES COTTON, EsQ.
}

Sir,-You now see I have returned you your very pleasant and useful discourse of "The Art of Fly-fishing." printed just as it was sent me; for 1 have been so obedient to your desires, as 10 endure all the praises you have ventured to fix upon me in it. And when I have thanked you for them, as the effeets of an undissembled love, then, let me tell you, sir, that I will readily endeavour to live up to the character you have given of me, if there were no other reason, yet for this alone, that you, that love me so well, and always think what you speak, may not, for my sake, suffer by a mistake in your judgment.

And, sir, I have ventured to fill a part of your margin, by way of paraphrase for the reader's clearer understanding the situation both of your fishing-house, and the pleasantness of that you dwell in. And I have ventured also to give him a "Copy of Verses" that you were pleased to send me, now some years past, in which he may see a good picture of both; and so much of your own mind too, as will make any reader, that is blessed with a generous soul, to love you the better. I confess, that for doing this you may justly judge me too bold: if you do, I will say so too; and so far commute for my offence, that, though I be more than a hundred miles from you, and in the eighty-third year of my age, yet I will forget both, and the next month begin a pilgrimage to beg your pardon; for I would die in your favour, and till then will live,

London, April 29, 1676.
Sir,

$$
\text { Your most affectionate father and friend, }
$$




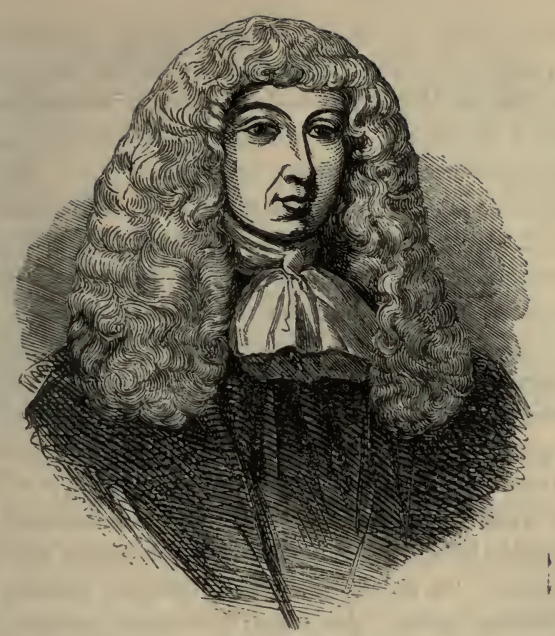

OHARLES COTTON.

\section{SKETCH OF COTTON'S LIFE.}

Charles Cottor was a country gentleman by birth and education. His father was of a high Hampshire family, his mother, daughter of Sir J. Stanhope, of Elraston, Derbyshire, of a still higher, for she was nearly related by consanguinity to the Earls of Chesterfield and Harrington. He was born in 1630 , and was thirty-seven years younger than Walton, who, as before stated, was born in 1593. At first he was edincated by a private tutor, and then transferred to the University of Cambridgc. He gained no honours, or, at least he took no degrees there. He seems to have cultivated the muses merely-not the musa severiores -aud returned to the paternal home an accomplished but not a profound scholar.

By virtue of his mother's title, his father became possessor of Beresford Hall, delightfully situated between the romantic Dovedale and the Peak, and close by the banks of the Dove-then the best trout and grayling stream in the empire. Here young Cotton, having no profession, resided under the family roof. Dwelling whilst young and aged 
within a stone's-throw of one of the most limpid and picturesque streams in England, with trout bounding in it and grayling rising rapidly at the March-brown or the May-fly, as it floated along, is it to be wondered at if he became a fly-fisher? The wonder would be if he had not. He did; and the most accomplished one of his day.

Long before his father's death he married-a love-match apparently, for it involved him in pecuniary difficulties from which he could never afterwards release himself. On his father's death he became sole possessor of Beresford Hall, but, alas, he had deeply mortgaged the property, and rental was swallowed up in interest ! It would appear that his time was occupied with fly-fishing and poetry, the latter consisting of translations from well-known foreign poets, Virgil amongst the rest, of whose Eneid he wrote a travestie. His works are very numerous, and it is thought he wrote for bread. In 1653, the first edition of "The Complete Angler" by Walton appeared, and hence arose an intimacy and then a lasting friendship between the fly-fisher of the Dove and the bottomfisher of the Lea. So ardent did this friendship become, that Cotton beseeched Walton to adopt him, which the latter granted, and thenceforward Cotton called father the now recognised father of Anglers. Walton paid frequent visits to Beresford Hall, between which and the river Dove, Cotton had erected a fishing-house (see infra, p. 260), in honour of his piscatorial parent. These circumstances, together with a formal adoption by Walton of Mr. Cotton for his son, already mentioned, were doubtless the inducements with the latter to the writing of a second part of the "Complete Angler," and therein to explain more fully the art of fishing either with a natural or an artificial fly, as also the various methods of making the latter: the book, as the author assures us, was written in the short space of ten days, and first came abroad with the fifth edition of the first part in the year 1676; and ever since the two parts have been considered as one book. It is the text of this edition that we reprint, and annotate so lengthily.

Cotton died in 1687 and Walton in 1683 ; the former surviving their conjoint literary and piscatorial labours eleven years, the latter seven. Cotton had married a second wife, the Countess Dowager Ardglass, and though she had a jointure of $£ 1500$ a-year, the life use of that sum tended merely to alleviate his narrow means, but not remove them. Still the estate was never forfeited. We saw Beresford Hall in 1838. It was then a large farm-house; the tenant an elderly lady. On her decease the late Marquis of Beresford purchased it, and has improved the place considerably, preserving, of course, the celebrated fishinghouse with its immortal inscription-SACRUM PISCATORIBUS. 


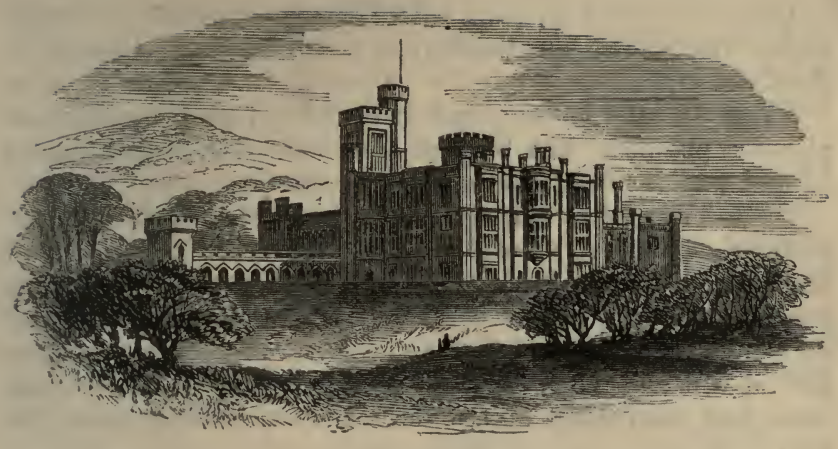

IBIANE HAII.

\section{THE COMPLETE ANGLER.}

\section{PART THE SECOND.}

\section{CHAPTER I.}

Piscator junior, and Viator.

\section{[ffirst 毗.]}

Pisc. You are happily overtaken, sir; may a man be so bold as to inquire how far you travel this way?

VIAT. Yes sure, sir, very freely, though it be a question I cannot very well resolve you, as not knowing myself how far it is to Ashborn, where I intend to-night to take up my inn.

PIsc. Why then, sir, seeing I perceive you to be a stranger in these parts, I shall take upon me to inform you, that from the town you last came through, called Brelsford, * it is five miles; and you are not yet above half a mile on this side.

VIAT. So much? I was told it was but ten miles from Derby ; and, methinks, I have rode almost so far already.

* Now spelt "Brailsford." It is a mere road-side village. Brailsford brook was once celebrated for its trout. I cannot speak highly of it now.-ED. 
Pisc. O sir, find no fault with large measure of good land, which Derbyshire abounds in, as much as most counties of England.

VIAT. It may be so ; and good land, I confess, affords a pleasant prospect: but, by your good leave, sir, large measure of foul way is not altogether so acceptable.

Pisc. True, sir; but the foul way serves to justify the fertility of the soil, according to the proverb, "There is good land where there is foul way " and is of good use to inform you of the riches of the country you are come into, and of its continual travel and traffic to the country town you came from: which is also very observable by the fulvess of its road, and the loaden horses you meet everywhere upon the way.

VIAT. Well, sir, I will be content to think as well of your country as you would desire; and I shall have a great deal of reason both to think and to speak very well of you, if I may obtain the happiness of your company to the fore-mentioned place, provided your affairs lead you that way, and that they will permit you to slack your pace, out of complacency to a traveller utterly a stranger in these parts, and who am still to wander further out of my own knowledge.

PISc. Sir, you invite me to my own advantage, and I am ready to attend you, my way lying through that town; but my business, that is, my home, some miles beyond it: however, I shall have time enough to lodge you in your quarters, and afterward to perfor'm my own journey. In the mean time, may I be so bold as to inquire the end of your journey?

VIAT. 'Tis into Lancashire, sir; and about some business of concern to a near relation of mine ; for I assure you, I do not use to take such long journeys as from Essex upon the single account of pleasure.

Pisc. From thence, sir! I do not then wonder you should appear dissatisfied with the length of the miles, and the foulness of the way: though I am sorry you should begin to quarrel with them so soon ; for, believe me, sir, you will find the miles much longer, and the way much worse, before you come to your journey's end.

VIAT. Why! truly, sir! for that I am prepared to expect the worst; but methinks the way is mended since $I$ had the good fortune to fall into your good company.

Pisc. You are not obliged to my company for that, but 
because you are already past the worst, and the greatest part of your way to your lodging.

VIAT. I am very glad to hear it, both for the ease of myself and my horse ; but especially, because I may then expect a freer enjoyment of your conversation : though the shortness of the way will, I fear, make me lose it the sooner.

PIsc. That, sir, is not worth your care: and I am sure you deserve much better for being content with so ill company. But we have already talked away two miles of your journey; for, from the brook before us, that runs at the foot of this sandy hill, you have but three miles to Ashborn.

Viat. I meet, everywhere in this country, with these little brooks; and they look as if they were full of fish : have they not trouts in them?

PIsc. That is a question which is to be excused in a stranger, as you are: otherwise, give me leave to tell you, it would seem a kind of affront to our country, to make a doubt of what we pretend to be famous for, next, if not before, our malt, wool, lead, and coal ; for you are to understand, that we think we have as many fine rivers, rivulets, and brooks, as any country whatever; and they are all full of trouts, and some of them the best, it is said, by many degrees, in England.

VIat. I was first, sir, in love with you; and now shall be so enamoured of your country by this account you give me of it, as to wish myself a Derbyshire man, or at least that I might live in it: for you must know I am a pretender to the angle, and, doubtless, a trout affords the most pleasure to the angler of any sort of fish whatever; and the best trouts must needs make the best sport : but this brook, and some others I have met with upon this way, are too full of wood for that recreation.

PIsc. This, sir! why this, and several others like it, which you have passed, and some that you are like to pass, have scarce any name amongst us : but we can show you as fine rivers, and as clear from wood, or any other incumbrance to hinder an angler, as any you ever saw ; and for clear, beautiful streams, Hantshire itself, by Mr. Izaak Walton's good leave, can show none such; nor I think any country in Europe.*

* This praise will not hold good now. Apart from certain preserved portions of the Dove, the other Derbyshire rivers are not first rate. 'They certainly are very pretty clear streams, and are difficult to fly-fish; the well-known Latlkil, on account of its extreme limpidness, the most difficult of all. The 
VIAT. You go far, sir, in the praise of your country rivers, and I perceive have read Mr. Walton's "Complete Angler," by your naming of Hantshire; and I pray what is your opinion of that book?

Pisc. My opinion of Mr. Walton's book is the same with every man's that understands anything of the art of angling, that it is an excellent good one, and that the fore-mentioned gentleman understands as much of fish, and fishing, as any man living: but I must tell you further, that I have the happiness to know his person, and to be intimately acquainted with him, and in him to know the worthiest man, and to enjoy the best, and the truest friend any man ever had; nay, I shall yet acquaint you further, that he gives me leave to call him Father, and I hope is not yet ashamed to own me for his adopted Son.

VIAT. In earnest, sir, I am ravished to meet with a friend of Mr. Izaak Walton's, and one that does him so much right in so good and true a character; for I must boast to you, that I have the good fortune to know him too, and came acquainted with him much after the same manner I do with you ; that he was my Master, who first taught me to love angling, and then to become an angler; and to be plain with you, I am the very man deciphered in his book under the name of Venator; for I was wholly addicted to the chace, till he taught me as good, a more quiet, innocent, and less dangerous diversion,

PIsc. Sir, I think myself happy in your acquaintance, and before we part shall entreat leave to embrace you ; you have said enough to recommend you to my best opinion : for my father Walton will be seen twice in no man's company he does not like, and likes none but such as he believes to be very honest men; which is one of the best arguments, or at least of the best testimonies I have, that I either am, or that he thinks me, one of those, seeing I have not yet found him weary of me.

trout of this brook are the most highly-coloured in the country, but not the best flavoured. The Wye, near Haddon Hall, and Longford-brook, ruming by and through the Earl of Leicester's seat and demesne of Longford, about six miles from Ashbourn, are favourite streams of mine. The Scotch and Irish trout streams are far better than those of Derbyshire, and so are some in Northumberland, Yorkshire, Herefordshire, Worcestershire, Gloucestershire, Devonshire, Wiltshire, Hampshire, Berkshire, and one or two in Surrey and Middlesex. The Driffield, in Yorkshire, and the Test, in Hampshire, are better angling rivers than the Dove.-ED. 
VIAT. You speak like a true friend, and in doing so render yourself worthy of his friendship. May I be so bold as to ask your name?

PIsc. Yes surely, sir, and if you please a much nicer question; my name is in your company, if I find you do not dislike mine, to ask yours too. In the meantime, because we are now almost at Ashborn, I shall freely and bluntly tell you, that I am a brother of the angle, too, and, peradventure, can give you some instructions how to angle for a trout in a clear river, that my father Walton himself will not disapprove, though he did either purposely omit, or did not remember them, ${ }^{*}$ when you and he sat discoursing under the sycamore tree. [See part i. p. S4.] And, being [seeing] you have already told me whither your journey is intended, and that I am better acquainted with the country than you are; I will heartily and earnestly entreat you will not think of staying at this town, but go on with me six miles farther to my house, $\uparrow$ where you shall be extremely welcome; it is directly in your way, we have day enough to perform our journey, and, as you like your entertainment, you may there repose yourself a day or two, or as many more as your occasions will permit, to recompense the trouble of so much a longer journey.

VIAT. Sir, you surprise me with so friendly an invitation upon so short acquaintance; but how advantageous soever it would be to me, and that my haste, perhaps, is not so great but it might dispense with such a divertisement as I promise myself in your company, yet I cannot, in modesty, accept your offer, and must therefore beg your pardon: I could otherwise, I confess, be glad to wait upon you, if upon no other account but to talk of Mr. I. Walton, and to receive those instructions you say you are able to give me for the deceiving a trout; in which art I will not deny but that I have an ambition to be one of the greatest deceivers: though I cannot forbear freely to tell you, that I think it hard to say much more than has been read to me upon that subject.

* The plain truth is, that Walton did not understand angling for " a trout in a clear stream," viz., fly-fishing for it. Cotton knew this well, but was too much of a courteous " cavalier" to say so bluntly.-ED.

+ Beresford-hall, situate a little to the north of Dovedale. In 1838 it was a large farm-house, and the property of the Marquis of Beresford. Between it and the river side is Cotton's fishing-house still standing.-ED. 
PIsc. Well, sir, I grant that, too; but you must know that the variety of rivers require different ways of angling : however, you shall have the best rules I am able to give, and I will tell you nothing I have not made myself as certain of, as any man can be in a thirty years' experience (for so long I have been a dabbler in that art); and that, if you please to stay a few days, you shall, in a very great measure, see made good to you. But of that hereafter; and now, sir, if I am not mistaken, I have half overcome you ; and that I may wholly conquer that modesty of yours, I will take upon me to be so familiar as to say, you must accept my invitation, which, that you may the more easily be persuaded to do, I will tell you that my house stands upon the margin of one of the finest rivers for trout and grayling in England ; that I have lately built a little fishing-house upon it, dedicated to anglers, over the door of which you will see the two first letters of my father Walton's name and mine twisted in cipher [see title page to Part II.]; that you shall lie in the sime bed he has sometimes been contented with, and have such country entertainment as my friends sometimes accept, and be as welcome, too, as the best friend of them all.

VIat. No doubt, sir, but my master Walton found good reason to be satisfied with his entertainment in your house ; for you who are so friendly to a mere stranger, who deserves so little, must needs be exceeding kind and free to him who deserves so much.

PIsc. Believe me, no: and such as are intimately acquainted with that gentleman know him to be a man who will not endure to be treated like a stranger. So that his acceptation of my poor entertainment has ever been a pure effect of his own humility and good-nature, and nothing else. But, sir, we are now going down* the Spittle Hill, into the town; and therefore let me importune you suddenly to resolve, and (most earnestly) not to deny me.

VIAT. In truth, sir, I am so overcome by your bounty, that I find I cannot, but must render myself wholly to be disposed of by you.

PIsc. Why, that's heartily and kindly spoken, and I as heartily thank you. And, being [seeing] you have abandoned * "Adown thy vale, romantic Ashbourn, glides,
The Derby dilly, with its six insides."

The political reader will recollect this quotation by $\mathrm{O}^{\prime} \mathrm{Connell,} \mathrm{and} \mathrm{applied} \mathrm{to}$ the then Iord Stanley.-ED. 
yourself to my conduct, we will only call and drink a glass on horseback at the Talbot, and away.

VIAT. I attend you. But what pretty river is this, that runs under this stone bridge? Has it a name?

Prsc. Yes, it is called Henmore ; and has in it both trout and grayling; but you will meet with one or two better anon. And so soon as we are past through the town, I will endeavour, by such discourse as best likes you, to pass away the time till you come to your ill quarters.

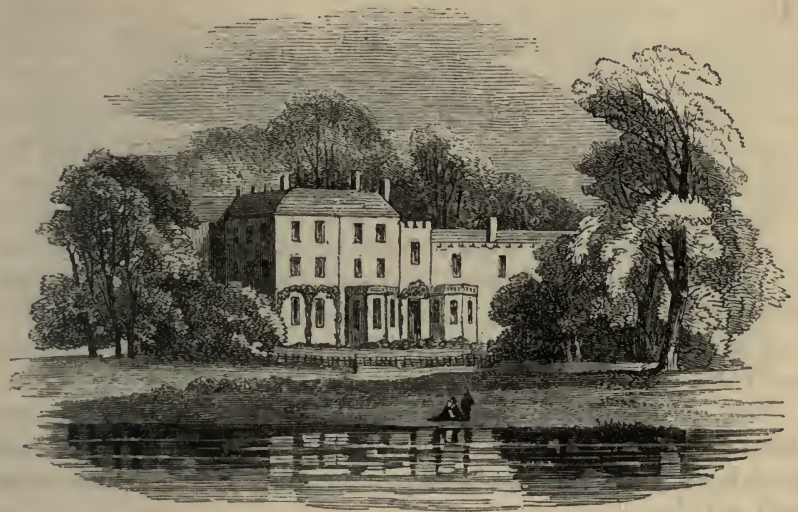

ASEBORN EALL.

VIAT. We can talk of nothing with which I shall be more delighted than of rivers and angling.

Pisc. Let those be the subjects, then; but we are now come to the Talbot. What will you drink, sir, ale, or wine?

VIAт. Nay, I am for the country liquor, Derbyshire ale, if you please ; for a man should not, methinks, come from London to drink wine in the Peak.

Prsc. You are in the right; and yet, let me tell you, you may drink worse French wine in many taverns in London, than they have sometimes at this house. What ho ! bring us a flagon of your best ale; and now, sir, my service to you, a

* Now called Shoo-brook, without a trout or grayling in it. 'Tis a mere ditch of running water, in which the little boys of Ashbourn commence their angling career by fishing for minnows.-ED. 
good health to the honest gentleman you know of, and you are welcome into the Peak.

VIAT. I thank you, sir, and present you my service again, and to all the honest brothers of the angle.

PIsc. I'll pledge you, sir : so, there's for your ale, and farewell. Come, sir, let us be going, for the sun grows low, and I would have you look about you as you ride; for you will see an odd country, and sights that will seem strange to you.

\section{CHAPTER II.}

\section{[ffirst \$an.]}

PIsc. So, sir, now we have got to the top of the hill out of town, look about you, and tell me how you like the country.

Viat. Bless me, what mountains are here! Are we not in Wales?

PIsc. No, butin almost as mountainous a country ; and yet these hills, though high, bleak, and craggy, breed and feed good beef and mutton, above ground, and afford good store of lead within.

VIAT. They had need of all those commodities to make amends for the ill landskip ; but I hope our way does not lie over any of these, for I dread a precipice.

PIsc. Believe me, but it does, and down one, especially, that will appear a little terrible to a stranger : though the way is passable enough, and so passable, that we who are natives of these mountains, and acquainted with them, disdain to alight.

VIAT. I hope, though, that a foreigner is privileged to use his own discretion, and that I may have the liberty to entrust my neck to the fidelity of my own feet, rather than to those of my horse, for I have no more at home.

PIsc. "Twere hard else. But in the meantime, I think 'twere best, while this way is pretty even, to mend our pace, that we may be past that hill I speak of; to the end your apprehension may not be doubled, for want of light to discern the easiness of the descent.

VIAT. I am willing to put forward as fast as my beast will 
give me leave, though $I$ fear nothing in your company. But what pretty river is this we are going into?

PIsc. Why this, sir, is called Bently-brook," and is full of very good trout and grayling; but so encumbered with wood in many places, as is troublesome to an angler.

VIAT. Here are the prettiest rivers, and the most of them in this country that ever I saw ; do you know how many you have in the country?

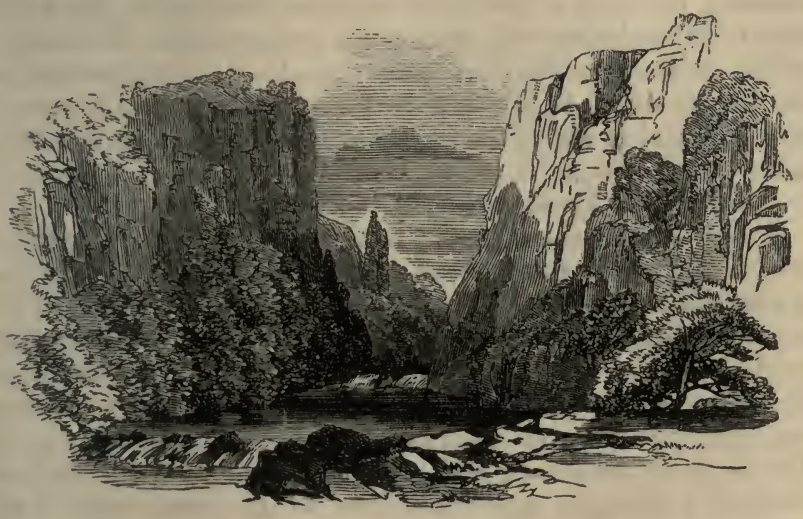

gTRAIFS OH DOVZ DALE,

PIsc. I know them all ; and they were not hard to reckon, were it worth the trouble, but the most considerable of them I will presently name you. And to begin where we now are, for you must know we are now upon the very skirts of Derbyshire; we have first the river Dove, that we shall come to by and by, which divides the two counties of Derby and Stafford for many miles together; and is so called from the swiftness of its current, and that swiftness occasioned by the declivity of its course, and by being so straitened in that course betwixt the rocks; by which, and those very high ones, it is, hereabout, for four or five miles, confined into a very narrow stream; a river that from a contemptible fountain, which I can cover with my hat, by the confluence of

* Two miles beyond Ashbourn, and still not a bad stream for trout and grayling.-ED. 
other rivers, rivulets, brooks, and rills, is swelled, before it falls into Trent, a little below Eggington, where it loses the name, to such a breadth and depth as to be in most places navigable, were not the passage frequently interrupted with fords and weirs ; and has as fertile banks as any river in England, none excepted. And this river, from its head for a mile or two, is a black water, as all the rest of the Derbyshire rivers of note originally are, for they all spring from the mosses ; but is in a few miles travel so clarified by the addition of several clear and very great springs, bigger than itself, which gush out of the limestone rocks, that before it comes to my house, which is but six or seven miles from its source, you will find it one of the purest crystalline streams you have seen.*

VIat. Does Trent spring in these parts?

Prsc. Yes, in these parts; not in this county, but somewhere towards the upper end of Staffordshire, I think not far from a place called Trentham; and thence runs down, not fa: from Stafford, to Wolsly Bridge, and, washing the skirts and purlieus of the forest of Needwood, runs down to Burton, in the same county; thence it comes into this, where we now are, and running by Swarkston and Dunnington, receives Derwent at Wildon; and, so, to Nottingham; thence, to Newark; and, by Gainsborough, to Kingston-upon-Hull, where it takes the name of Humber, and thence falls into the sea; but that the map will best inform your.

Viat. Know you whence this river Trent derives its name?

PIsc. No, indeed ; and yet I have heard it often discoursed upon: when some have given its denomination from the forenamed Trentham, though that seems rather a derivative from it ; others have sair it is so called from thirty rivers that fall into it, and there lose their names; which cannot

* Between Beresford-hall and Ashbourn lies Dove-dale, whose crested clifts and swift torrents are again noticed by Mr. Cotton in his "Wonders of the Peak." Through this singularly deep valley the Dove runs for about two miles, changing its course, its motion, and its appearance perpetually ; never less than ten, and rarely so many as twenty yards in width; making a continued noise by rolling over or falling among loose stones. The rocks which form its sides are heaved up in enormous piles, sometimes connected witl each other and sometimes detached; some perforated in natural cavities, others adorned with foliage; with here and there a tall rock, having nothing to relieve the bareness of its appearance but a mountain-ash flourishing at the top. The grandeur of its scenery is probably unrivalled in England.-H. 
be, neither, because it carries that name from its very fountain, before any other rivers fall into it: others derive it from thirty several sorts of fish that breed there; and that is the most likely derivation: but be it how it will, it is doubtless one of the finest rivers in the world, and the most abounding with excellent salmon, and all sorts of delicate fish.*

Viat. Pardon me, sir, for tempting you into this digression; and then proceed to your other rivers, for I am mightily delighted with this discourse.

PIsc. It was no interruption, but a very seasonable question : for Trent is not only one of our Derbyshire rivers, but the chief of them, and into which all the rest pay the tribute of their names, which I had, perhaps, forgot to insist upon, being got to the other end of the county, had you not awoke my memory. But I will now proceed. And the nextriver of note, for I will take them as they lie eastward from us, is the river Wye; I say of note, for we have two lesser betwixt us and it, namely, Lathkin and Bradford ; of which Lathkin is, by many degrees, the purest and most transparent stream that I ever yet saw, either at home or abroad, and breeds, it is said, the reddest and the best trouts in England: but neither of these are to be reputed rivers, being no better than great springs. The river Wye, then, has its source near unto Buxton, a town some ten miles hence, famous for a warm bath, and which you are to ride through in your way to Manchester ; a black water, too, at the fountain, but, by the same reason with Dove, becomes very soon a most delicate, clear liver, and breeds admirable trout and grayling, reputed by those who, by living upon its banks, are partial to it, the best

* There are no salmon in the Trent, now, and not many trout and grayling. Its tront, though few, grow to a large size, sometimes, but very rarely as large as those of the Thames. It is an excellent river for pike, perch, barbel, cliub, and other coarse fish. I do not think it produces thirty different sorts of fish. IIany think the contrary, but have not specifically named them. Others maintain that it derives its name from having thirty (trente) tributaries, and agree that Miltou's distich, in his well-known description of English rivers, should be read-

$$
\begin{aligned}
& \text { "Or. Trent, who like an earth-born giant, spreads } \\
& \text { Its thirty arms along the indented meads," }
\end{aligned}
$$

instead of thirsty, the usual reading. I am inclined to think that thirsty is a graphical, or typographical error-that Milton wrote thirty, and was thinking, when he did so, of the earth-born (son of Colus and Terra) giant, Briareus, and his hundred arms. Walton inclines to the opinion that the Trent derives its name from thirty different sorts of fish found in it, and not because it is said to have thirty tributaries. Milton, whether he wrote thirsty or thirty, did not think so, nor do I either.-ED. 
of any ; and this, running down by Ashford, Bakewell, and Hadden, at a town a little lower, called Rowsly, falls into Derwent, and there loses its name.* The next in order is Derwent, a black water, too, and that not only from its fountain, but quite through its progress, not having these crystal springs to wash and cleanse it which the two fore-mentioned have ; but abounds with trout and grayling, such as they are, towards its source, and with salmon below : and this river, from the upper and utmost part of the county, where it springs, taking its course by Chatsworth, Darley, Matlock, Derby, Burrow-Ash, and A wberson, falls into Trent at a place called Wildon, and there loses its name. The east side of this county of Derby is bounded by little inconsiderable rivers, as Awber, Eroways, and the like, searce worth naming, but trouty, too ; and further we are not to enquire. But, sir, I have carried you, as a man may say, by water, till we are now come to the descent of the formidable hill I told you of, at the foot of which runs the river Dove, which I cannot but love above all the rest; and therefore prepare yourself to be a little frighted.

VIAT. Sir, I see you wonld fortify me, that I should not shame myself: but I dare follow where you please to lead me; and I see no danger yet; for the descent, methinks, is thus far green, even, and easy.

Prsc. You will like it worse presently, when you come to the brow of the hill ; and now we are there, what think you?

VIat. What do I think? Why I think it the strangest place that ever, sure, men and horses went down; and that, if there be any safety at all, the safest way is to alight.

Pisc. I think so too, for you, who are mounted upon a beast not acquainted with these slippery stones; and though I frequently ride down, I will alight, too, to bear you company, and to lead you the way; and, if you please, my man shall lead your horse.

* By this it appears, that there are two rivers in England that bear the name of the Wye; the former Wye, has, as well as the Severn, its head in the Plinlimmon hills, on the borders of Montgomery and Cardiganshires; from whence, as its Latin name, Vaga, imports, wandering through part of Brecknockshire, it, near the Hay, enters Herefordshire; and at Mordiford, within four miles of Hereford, receives the Lug; from thence, passing on to Ross, it enters Monmouthshire, and falls into the Severn below Chepstow. It abounds with that small species of fish called last-springs; and also with grayling.-H.

[NoTE.- "Last-springs" are in reality pure salmon-fry, and not a small distinct species of fish. The Wye, where it passes Herefordshire and Monmouthshire, is a good salmon river.-ED.] 
VIAT. Marry, sir, and thank you, too : for I am afraid I shall have enough to do to look to myself; and, with my horse in my hand should be in a double fear, both of breaking my neck, and my horse's falling on me; for it is as steep as a penthouse.

PIsc. To look down from hence it appears so, I confess; but the path winds and turns, and will not be found so troublesome.

VIAT. Would I were well down though! Hoist thee! there's one fair 'scape! these stones are so slippery I cannot stand ! yet again! I think I were best lay my heels in my neck, and tumble down.

PIsc. If you think your heels will defend your neck, that is the way to be soon at the bottom; but give me your hand at this broad stone, and then the worst is past.

VIAT. I thank you, sir, I am now past it, I can go myself. What's here the sign of a bridge? Do you use to travel with wheelbarrows in this country?

Prsc. Not that I ever saw, sir. Why do you ask that question?

VIAT. Because this bridge certainly was made for nothing else; why, a mouse can hardly go over it: 'tis not two fingers broad.

Pisc. You are pleasant, and I am glad to see you so : but I have rid over the bridge many a dark night.

VIAT. Why, according to the French proverb, and 'tis a good one amoug a great many of worse sense and sound that language abounds in, Ce que Dieu garde, est bien gardé. "They whom God takes care of are in safe protection :" but, let me tell you, I would not ride over it for a thousand pounds, nor fall off it for two; and yet I think I dare venture on foot, though if you were not by to laugh at me, I should do it on all fours.

Pisc. Well, sir, your mirth becomes you, and I am glad to see you safe over; and now you are welcome into Staffordshire.

VIat. How, Staffordshire! What do I there, trow ? there is not a word of Staffordshire in all my direction.

PIsc. You see you are betrayed into it, but it shall be in order to something that will make amends; and 'tis but an ill mile or two out of your way.

VIAт. I believe all things, sir, and doubt nothing. Is this your beloved river, Dove? 'Tis clear and swift, indeed, but a very little one. 
PISc. You see it here at the worst: we shall come to it anon again, after two miles riding, and so near as to lie upon the very banks.

VIAT. Would we were there once: but I hope we have no more of these Alps to pass over.

PISc. No, no, sir ; only this ascent before you, which you see is not very uneasy, and then you will no more quarrel with your way.

VIAT. Well, if ever I come to London, of which many a man there, if lie were in my place, would make a question, I will sit down and write my travels ; and, like Tom Coriate," print them at my own charge. Pray what do you call this hill we came down?

Pisc. We call it Hanson Toot.

Vrat. Why, farewell, Hanson Toot! I'll no more on thee: I'll go twenty miles about first : Puh ! I sweat that my shirt sticks to my back.

PISC. Come, sir, now we are up the hill; and now how do you?

VIAT. Why, very well, I humbly thank you, sir ; and warm enough, I assure you. What have we here, a church? As I'm an hovest man, a very pretty church? Have you churches in this country, sir?

* Tom Coriate lived in the reign of King James the First; and, as Wood calls him, was the whetstone of all the wits of that age: and, indeed, the allusions to him, and to the singular oddness of his character, are numberless. He travelled almost over Europe on foot; and in that tour walked 900 miles with one pair of shoes, which he got mended at Zurich. Afterwards he visited Turkey, I'ersia, and the Great Mogul's dominions, travelling in so frugal a manner, that-as he tells his mother, in a letter to her-in his ten months' travels, between Alepro and the Mrogul's court, he spent but three pounds sterling; living remarkably well for about twopence sterling a day; and of that three pounds he elsewhere says, he was cozened of no less than ten shillings sterling by certain Christians of the Armenian nation; so that, indeed, he spent but fifty shillings in his ten months' travels. In these, his travels, he attained to great perfection both in the Persian and Hindostan languages; in the former, he made and pronouneed an oration to the Great Mogul ; and his skill in the latter he took oceasion to manifest in the following very signal instance. In the service of the English ambassador, then resident, was a wornan of Hindostan, a laundress, whose frequent practice it was to scold, brawl, and rail, from sunrising to sunset. This formidable shrew did Coriate one day undertake to scold with, in her own language; and succeeded so well in the attempt, that, by eight of the elock in the morning, he had totally silenced her, learing her not a word to speak. Further it appears, that he was a zealous cliampion for the Cliristian religion against the Mahometans and the Pagans, in the defence whereof he sometimes risked his life. He died of the flux, occasioned by drinking sack, at Surat, in 1617: having published his European travels in a quarto volume, which he called his "Crudities;" and to this circumstance the passage in the text is a manifest allusion.- $-\mathrm{H}$. 
Pisc. You see we have: but had you seen noue, why should you make that doubt, sir?

VIAT. Why, if you will not be angry, I'll tell you ; I thought myself a stage or two beyoud Christendom.

PIsc. Come, come, we'll reconcile you to our country before we part with you, if showing you good sport with angling will do it.

VIAT. My respect to you, and that together, may do much, sir; otherwise, to be plain with you, I do not find myself much inclined that way.

PIsc. Well, sir, your raillery upon our mountains has brought us almost home ; and look you where the same river of Dove has again met us to bid you welcome, and to invite you to a dish of trouts to-morrow.

VIat. Is this the same we saw at the foot of PenmenMaure? It is a much finer river here.

PIsc. It will appear yet much finer to-morrow. But look you, sir, here appears the house, that is now like to be your imn, for want of a better.

Viat. It appears on a sudden, but not before 'twas looked for; it stands prettily, and here's wood about it too, but so young, as appears to be of your own planting.

PIsc. It is so ; will it please you to alight, sir? and now permit me, after all your pains and dangers, to take you in my arms, and to assure you, that you are infinitely welcome.

VIAT. I thank you, sir, and am glad with all my heart I am here ; for, in downright truth, I am exceeding weary.

PIsc. You will sleep so much the better; you shall presently have a light supper, and to bed. Come, sirs, lay the cloth, and bring what you have presently, and let the gentleman's bed be made ready in the meantime, in my father Walton's chamber ; and now, sir, here is my service to you and once more welcome.

VIAT. Ay marry, sir, this glass of good sack has refreshed me, and I'll make as bold with your meat, for the trot has got me a good stomach.

Pisc. Come, sir, fall to, then, you see my little supper is always ready when I come home ; and I'll make no stranger of you.

VIAT. That your meal is so soon ready is a sign your servants know your certain hours, sir ; I confess I did not expect it so soon ; but now 'tis here, vou shall see I will make myself no stranger. 
PIsc. Much good do your heart, and I thank you for that friendly word : and now, sir, my service to you in a cup of More-Lands ale : for you are now in the More-Lands, but within a spit and a stride of the Peak; fill my friend his glass.

VIAT. Believe me, you have good ale in the More-Lands, far better than that at Ashborn.*

PIsc. That it may soon be : for Ashborn has, which is a kind of riddle, always in it the best malt, and the worst ale in England. + Come, take away, and bring us some pipes, and a bottle of ale, and go to your own suppers. Are you for this diet, sir?

VIAT. Yes, sir, I am for one pipe of tobacco; and I perceive yours is very good by the smell.

PIsc. The best I can get in London, I assure you. $\ddagger$ But,

* The name of this pretty town is variously written,-Ashborn, $\Delta$ shbourn, Ashborne. The latter is the modern way of spelling it.-ED.

+ Such is not the case now, but quite the reverse. Ashborne ale is as good as that of any other town in England. Each publican brews his own ale; hence a competition that leads to excellency. It is the same at Nottingham; and I class amongst the best, pleasantest, and purest ales sold publicly those of the above towns. The cellars in each are merely excavations in rock and sandstone, and are peculiarly adapted for preserving and improving malt liquors.-ED.

$\ddagger$ It should seem, by what Walton says, Chap. X. Part I., that he was a smoker : and the reader sees, by the passage in the text, that Piscator, by whom we are to understand Cotton himself, is so curious as to have his tobacco from London. But our piscatory disciple may do as he pleases. Smoking, or, as the phrase was, taking tobacco, was, in Queen Elizabeth's and her successor's time, esteemed the greatest of all foppery. Ben Jonson, who mortally hated it, had numberless sarcasms against smoking and smokers; all of which are nothing, compared to those contained in that work of our King James the First, " A Counter-blast to Tobacco." Nor was the ordinary conversation of this monarch less fraught with reasons and invectives against the use of that weed, as will appear from the following saying of his, extracted from " A Collection of Witty Apophthegms," delivered by him and others, at several times, and on sundry occasions, published in $12 \mathrm{mo}, 1671$. "That tobacco was the lively image and pattern of hell; for that it had, by allusion, in it all the parts and vices of the world whereby hell may be gained; to wit: First, It was a smoke; so are the vanities of this world. Secondly, It delighteth them who take it; so do the pleasures of the world delight the men of the world. Thirdly, It maketh men drunken and light in the head: so do the vanities of the world: men are drunken therewith. Fourthly, He that takes tobacco saith he cannot leave it, it doth bewitch him: even so do the pleasures of the world make men loath to leave them, they are for the most part so enchanted with them. And further, besides all this, it is like hell in the very substance of it, for it is a stinking loathsome thing; and so is hell. And further, his majesty professed that, were he to invite the devil to dinner, he should have three dishes; $1 . \mathbf{A}$ pig; 2. A pole of ling and mustard ; and 3. A pipe of tobacco for digesture." In Herefordshire, to signify the last or concluding pipe that any one means to smoke at a sitting, they use the term a Kemble pipe, alluding to a man of the name of Kemble, who in the cruel persecution under the merciless bigot Queen 
sir, now you have thus far complied with my designs, as to take a troublesome journey into an ill country, only to satisfy me; how long may I hope to enjoy you?

VIAT. Why truly, sir, as long as I conveniently can; and longer, I think, you would not have me.

Prsc. Not to your inconvenience by any means, sir : but I see you are weary, and therefore I will presently wait on. you to your chamber, where, take counsel of your pillow; and, to-morrow resolve me. Here, take the lights; and pray follow them, sir : here you are like to lie; and now I have showed you your lodgings, I beseech you, command anything you want, and so I wish you good rest.

Vrat. Good night, sir.*

\section{CHAPTER III.}

\section{[รีeconส 田an.]}

Pisc. Good morrow, sir ; what! up and drest so early?

VIAT. Yes, sir, I have been drest this half hour; for I rested so well, and have so great a mind either to take, or to see a trout taken in your fine river, that I could no longer lie abed.

Prsc. I am so glad to see you so brisk this morning, and so eager for sport; though I must tell you, this day proves so calm, and the sun rises so bright, as promises no great success to the angler; but, however, we'll try, and, one way or other, we shall sure do something. What will you have to your breakfast, or what will you drink this morning?

Vrat. For breakfast, I never eat any, and for drink am very indifferent; but if you please to call for a glass of ale, I'm for you ; and let it be quickly, if you please, for I long to see the little fishing-house you spoke of, and to be at my lesson.

Mary, being condemned for heresy, in his walk of some miles from the prison to the stake, amidst a crowd of weeping friends, with the tranquillity and fortitude of a primitive martyr, smoked a pipe of tobacco.-H.

* The gentlemanly hospitality of Piscator, by whom we are here to understand Mr. Cotton himself, in his behaviour to a stranger, manifested in the foregoing part of the dialogue, and in this instance of courtesy, is well worth noting. $-\mathrm{H}$. 
PIsc. Well, sir, you see the ale is come without calling; for though I do not know yours, my people know my diet, which is always one glass so soon as I am drest, and no more, till dinner: and so my servants have served you.

VIAT. My thanks! And now, if you please, let us look out this fine morning.

Pisc. With all my heart. Boy, take the key of my fishinghouse, and carry down those two angle-rods in the hall window, thither, with my fish-pannier, pouch, and landingnet; and stay you there till we come. Come, sir, we'll walk after, where, by the way, I expect you should raise all the exceptions against our country you can.

VIAT. Nay, sir, do not think me so ill-natured nor so uncivil ; I only made a little bold with it last night to divert you, and was only in jest.

PIsc. You were then in as good earnest as I am now with you : but had you been really angry at it, I could not blame you : for, to say the truth, it is not rery taking at first sight. But look you, sir, now you are abroad, does not the sun shine as bright here as in Essex, Middlesex, or Kent, or any of your southern counties?

VIAT. It is a delicate morning, indeed; and I now think this a marvellous pretty place.

PIsc. Whether you think so or no, you cannot oblige me more than to say so ; and those of my friends who know my

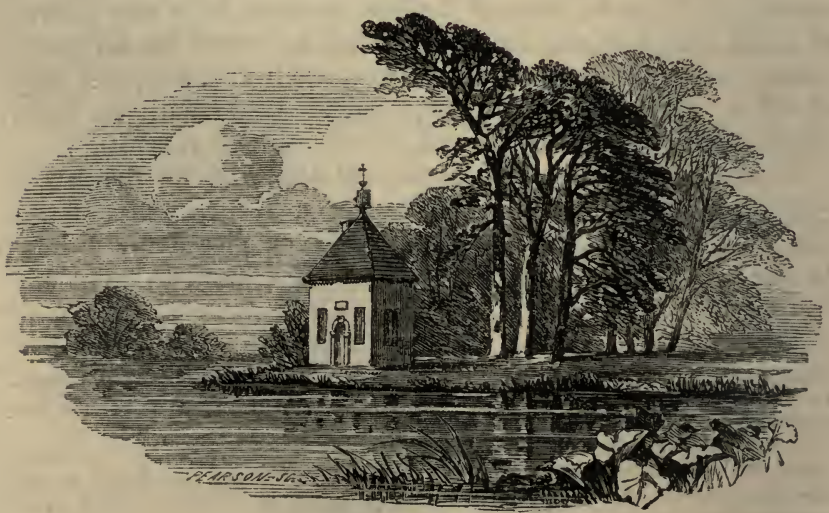

COTTON'a FנBEING HOUЯE. 
humour, and are so kind as to comply with it, usually flatter me that way. But look you, sir, now you are at the brink of the hill, how do you like my river, the vale it winds through like a snake, and the situation of my little fishinghouse?

VIAT. Trust me, 'tis all very fine, and the house seems at this distance a neat building.

Pisc. Good enough for that purpose : and here is a bowling-green too, close by it; so, though I am myself no very good bowler, I am not totally devoted to my own pleasure, but that I have also some regard to other men's. And now, sir, you are come to the door, pray walk in, and there we will sit and talk as long as you please.

Viat. Stay, what's here over the door? Piscatoribus SACrum.* Why then, I perceive I have some title here; for I am one of them, though one of the worst; and here below it is the cypher too you spoke of, and 'tis prettily contrived. Has my master Walton ever been here to see it, for it seems: new built ? +

Pisc. Yes, he saw it cut in the stone before it was set up;: but never in the posture it now stands; for the house was but building when he was last here, and not raised so high as the arch of the door. And I am afraid he will not see it yet; for he has lately writ me word, he doubts his coming dow $n$ this summer; which, I do assure you, was the worst news he could possibly have sent me.

VIAT. Men must sometimes mind their affairs to make

* There is, under this motto, the cypher prefigured in the title-page to the second part of this work. And some part of the fishing-house has been already described; but the pleasantness of the river, mountains, and meadows about it, cannot, unless Sir Philip Sidney, or Mr. Cotton's father, were again alive to. do it.

+ I have been favoured with an accurate description of this fishing-house, by a person, who, being in that country, with a view to oblige me, went to see it. The account he gave of it is, that it is of stone, and the room inside a cube of fifteen feet; that it is paved with black and white marble, and that in the middle is a square black marble table, supported by two stone feet. The room. is wainscoted, with curious mouldings that divide the panels up to the ceiling. In the larger panels are represented, in painting, some of the most pleasant of the adjacent scenes, with persons fishing; and in the smaller, the various sorts of tackle and implements used in angling. In the farther corner, on the left, is a fire-place with a chimney; on the right, a large beaufet, with foldingdoors, whereon are the portraits of Mr. Cotton, with a boy servant, and Walton, in the dress of the time. Underneath is a cupboard; on the door whereof the figures of a trout and a grayling are well portrayed. The edifice is at this time (1748) in but indifferent condition; the paintings, and even the wainscoting, in many places, being much decayed.-Hawkins (son of Sir John) 
more room for their pleasures : and 'tis odds he is as much displeased with the business that keeps him from you, as you are that he comes not. But I am most pleased with this little house of any thing I ever saw : it stands in a kind of peninsula too, with a delicate clear river about it. I dare hardly go in, lest I should not like it so well within as without: but, by your leave, I'll try. Why, this is better and better, fine lights, fine wainscoted, and all exceeding neat, with a marble table and all in the middle !

PIsc. Enough, sir, enough; I have laid open to you the part where I can worst defend myself, and now you attack me there. Come, boy, set two chairs; and whilst I am taking a pipe of tobacco, which is always my breakfast, we will, if you please, talk of some other subject.

Viat. None fitter, then, sir, for the time and place, than those instructions you promised.

Prsc. I begin to doubt, by something I discover in you, whether I am able to instruct you or no; though, if you are really a stranger to our clear northern rivers, I still think I can : and therefore, since it is yet too early in the morning at this time of the year, to-day being but the serenth of March, to cast a fly upon the water, if you will direct me what kind of fishing for a trout I shall read you a lecture on, I am willing and ready to obey you.

VIAT. Why, sir, if you will so far oblige me, and that it may not be too troublesome to you, I would entreat you would run through the whole body of it; and I will not conceal from you that I am so far in love with you, your courtesy, and pretty More-Land seat, as to resolve to stay with you long enough by intervals, for I will not oppress you to hear all you can say upon that subject.

PIsc. You cannot oblige me more than by such a promise: and therefore, without more ceremony, I will begin to tell you, that my father Walton having read to you before, it would look like a presumption in me (and, peradventure, would do so in any other man), to pretend to give lessons for angling after him, who, I do really believe, understands as much of it at least as any man in England, did I not preacquaint you, that I am not tempted to it by any vain opinion of myself, that I am able to give you better directions; but having, from my childhood, pursued the recreation of angling in very clear rivers, truly I think by much, some of them at least, the clearest in this kingdom, and the manner 
of angling here with us, by reason of that exceeding clearness, being something different from the method commonly used in others, which by being not near so bright, admit of stronger tackle, and allow a nearer approach to the stream; I may peradventure give you some instructions that may be of use, even in your own rivers, and shall bring you acquainted with more flies, and show you how to make them, and with what dubbing too, than he has taken notice of in his CoMplete ANGLER.

VIAT. I beseech you, sir, do: and if you will lend me your steel, I will light a pipe the while; for that is commonly my breakfast in a morning too.

\section{CHAPTER IV.}

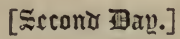

Pisc. Why then, sir, to begin methodically, as a master in any art should do; and I will not deny but that I think myself a master in this, I shall divide angling for trout or grayling into these three ways; at the top, at the bottom, and in the middle. Which three ways, though they are all of them, as I shall hereafter endeavour to make it appear, in some sort common to both those kinds of fish, yet are they not so generally and absolutely so, but that they will necessarily require a distinction, which, in due place, I will also give you.

That which we call angling at the top is with a fly; at the bottom, with a ground-bait; in the middle, with a minnow or ground-bait.

Angling at the top is of two sorts; with a quick [live] fly, or with an artificial fly.

That we call angling at the bottom is also of two sorts; by the hand, or with a cork or float.

That we call angling in the middle is also of two sorts; with a minnow for a trout, or with a ground-bait for a grayling.*

* Angling " in the middle," means trolling and spinning. Fishing with a ground-bait for grayling is not angling at the middle, but at the bottom. There is a method of fishing for grayling and other fish called "sinking and drawing," which consists in part of fishing at the bottom, the middle, and nearly at the top. 
Of all which several sorts of angling, I will, if you can have the patience to hear me, give you the best account I can.

Viat. The trouble will be yours, and mine the pleasure and the obligation: I beseech you therefore to proceed.

PIsc. Why then, first of fly-fishing.

\section{CHAPTER V. \\ OF FLY - FISHING. \\ [天reñ 田an.]}

Prsc. Fly-fishing, or fishing at the top, is, as I said before, of two sorts; with a natural and living fly, or with an artificial and made fly.

First then, of the natural fly: of which we generally use but two sorts ; and those but in the two months of May and June only; namely, the green drake and the stone-fly: though I have made use of a third, that way, called the camlet-fly, with very good success, for grayling, but never saw it angled with by any other, after this manner, my master only excepted, who died many years ago, and was one of the best anglers that ever I knew.

These are to be angled with, with a short line, not much more than half the length of your rod, if the air be still ; or with a longer, very near, or all out, as long as your rod, if you have any wind to carry it from you. And this way of fishing we call daping, dabbing, or dibbing ; * wherein you are always to have your line flying before you up or down the river, as the wind serves, and to angle as near as you can to the bank of the same side whereon you stand, though where you see a fish rise near you, you may guide your quick [live] fly over him, whether in the middle, or on the contrary side; and if you are pretty well out of sight, either by kneeling or the interposition of a bank or bush, you may almost be sure to raise, and take him too, if it be presently done; the fish will, otherwise, peradventure be removed to some other place, if it be in the still deeps, where he is always in motion, and roving

* I have already described this mode of angling at the end of chap. iif. p. 59.-ED. 
up and down to look for prey, though, in a stream, you may always almost, especially if there be a good stone near, find him in the same place. Your line ought in this case to be three good hairs next the hook, both by reason you are in this kind of angling to expect the biggest fish, and also that wanting length to give him line after he is struck, you must be forced to tug for it; to which I will also add that not an inch of your line being to be suffered to touch the water in dibbing, it may be allowed to be the stronger. I should now give you a description of those flies, their shape and colour, and then give you an account of their breeding, and withal show you how to keep and use them; but shall defer them to their proper place and season.

VIAT. In earnest, sir, you discourse very rationally of this affair, ${ }^{*}$ and I am glad to find myself mistaken in you ; for in truth I did not expect so much from you.

Pisc. Nay, sir, I can tell you a great deal more than this, and will conceal nothing from you. But I must now come to the second way of angling at the top, which is with an artificial fly, which also I will show you how to make before I have done, but first shall acquaint you, that with this you are to angle with a line longer by a yard and a half, or sometimes two yards, than your rod; and with both this and the other, in a still day in the streams, in a breeze that curls the water in the still deeps, where (excepting in May and June, that the best trouts will lie in shallow streams to watch for prey, and even then too) you are like to hit the best fish.

For the length of your rod, you are always to be governed by the breadth of the river you shall chuse to angle at; and for a trout-river, one of five or six yards longt is commonly enough; and longer, though never so neatly and artificially made, it ought not to be, if you intend to fish at ease; and if otherwise, where lies the sport?

Of these, the best that ever I saw are made in Yorkshire, which are all of one piece; that is to say, of several, six, eight, ten, or twelve pieces, so neatly pieced and tied together with fine thread below, and silk above, as to make it taper like a switch, and to ply with a true bent to your hand; and

* This compliment is well-deserved : Cotton understood "daping, dabbing, or dibbing" well, and teaches it soundly.-En.

+ Too long by one or two yards. See remarks on fishing-rods at the end of chap. xxi., part i.-ED. 
these too are light, being made of fir-wood for two or three lengths nearest to the hand, and of other wood nearer to the top, that a man might very easily manage the longest of them that ever I saw, with one hand; and these, when you have given over angling for a season, being taken to pieces, and laid up in some dry place, may afterwards be set together again in their former postures, and will be as straight, sound, and good, as the first hour they were made ; and being laid in oil and colour, according to your master Walton's direction, will last many years.

The length of your line, to a man that knows how to handle his rod, and to cast it, is no manner of incumbrance, excepting in woody places, and in landing of a fish, which every one that can afford to angle for pleasure, has somebody to do for him ; and the length of line is a mighty advantage to the fishing at a distance ; and to fish fine, and far off, is the first and principal rule for trout-angling.*

Your line in this case should never be less, nor ever exceed two hairs next to the hook; for one, (though some, I know, will pretend to more art than their fellows) is indeed too few, the least accident, with the finest hand, being sufficient to break it: but he that cannot kill a trout of twenty inches long with two, in a river clear of wood and weeds, as this and some others of ours are, deserves not the name of an angler.

Now, to have your whole line as it ought to be, two of the first lengths nearest the hook should be of two hairs a-piece ; the next three lengths above them of three; the next three above them of four; and so of five, and six, and seven, to the very top : by which means, your rod and tackle will, in a manner, be taper from your very hand to your hook; your line will fall much better and straighter, and cast your fly to any certain place, to which the hand and eye shall direct it, with less weight and violence, than would otherwise circle the water, and fright away the fish.

* An artist may easily throw twelve yards of line with one hand; and with two, he may as easily throw eighteen.-H.

[An accomplished fly-fisher of the present day can throw his fly a distance of fifteen yards with a single-handed rod, and twenty-five and even thirty yards with the double-lianded salmon-rod. Modern superiority in throwing the fly is the result of fishing with far better rods and lines than those used in the time of Sir John Hawkins-about a century ago. Since 1836, when I first began to write upon angling, the improvement in all sorts of fishing-tackle has been wonderfully progressive, marked, and useful.-ED.] 
In casting your line, do it always before you, and so that your fly may first fall upon the water, and as little of your line with it as is possible; though if the wind be stiff, you will then of necessity be compelled to drown a good part of your line to keep your fly in the water : and in casting your fly, you must aim at the further or nearer bank as the wind serves your turn, which also will be with and against you, on the same side, several times in an hour, as the river winds in its course, and you will be forced to angle up and down by turns accordingly, but, endeavour, as much as you can, to have the wind, evermore, on your back. And always be sure to stand as far off the bank as your length will give you leave when you throw to the contrary side: though when the wind will not permit you so to do, and that you are constrained to angle on the same side whereon you stand, you must then stand on the very brink of the river, and cast your fly to the utmost length of your rod and line, up or down the river, as the gale serves.

It only remains, touching your line, to inquire whether your two hairs next to the hook are better twisted or open? And for that I should declare that I think the open way the better, because it makes less show in the water, but that I have found an inconvenience, or two, or three, that have made me almost weary of that way; of which, one is, that, without dispute, they are not so strong open as twisted; another, that they are not easily to be fastened of so exact an equal length in the arming that the one will not cause the other to bag, by which means a man has but one hair upon. the matter to trust to ; and the last is that these loose flying hairs are not only more apt to catch upon every twig or bent they meet with, but, moreover, the hook, in falling upon the water, will, very often, rebound and fly back betwixt the hairs, and there stick (which, in a rough water especially, is not presently to be discerned by the angler), so as the point of the hook shall stand reversed; by which means your fly swims backward, makes a much greater circle in the water, and till taken home to you and set right, will never raise any fish, or, if it should, I am sure, but by a very extraordinary chance, can hit none.*

* This cannot happen with the present gut casting-lines, the only sort that should be used for fly-fishing. For making them, casting with them, working the flies in the water-hooking, playing, landing a fish-see my instructions at the end of this chapter.-ED. 
Having done with both these ways of fishing at the top, the length of your rod, and line and all, I am next to teach you how to make a fly; and afterwards of what dubbing you are to make the several flies I shall hereafter name to you.

In making a fly then, which is not a hackle or palmer-fly (for of those, and their several kinds, we shall have occasion to speak every month in the year) you are first to hold your hook fast betwixt the fore-finger and thumb of your lefthand, with the back of the shank upwards, and the point towards your finger's ends; then take a strong small silk, of the colour of the fly you intend to make, wax it well with wax of the same colour too (to which end, you are always, by the way, to have wax of all colours about you), and draw it betwixt your finger and thumb, to the head of the shank, and then whip it twice or thrice about the bare hook, which you must know is done, both to prevent slipping, and also that the shank of the hook may not cut the hairs of your towght, which sometimes it will otherwise do : which being done, take your line, and draw it likewise betwixt your finger and thumb, holding the hook so fast as only to suffer it to pass by, until you have the knot of your towght almost to the middle of the shank of your hook, on the inside of it ; then whip your silk twice or thrice about both hook and line, as hard as the strength of the silk will permit; which being done, strip the feather for the wings proportionable to the bigness of your fly, placing that side downwards which grew uppermost before, upon the back of the hook, leaving so much only as to serve for the length of the wing of the point of the plume, lying reversed from the end of the shank upwards; then whip your silk twice or thrice about the root-end of the feather, hook, and towght; which being done, clip off the root-end of the feather close by the arming, and then whip the silk fast and firm about the hook and towght, until you come to the bend of the hook, but not further, as you do at London, and so make a very unhandsome, and, in plain English, a very unnatural and shapeless fly; which being done, cut away the end of your towght, and fasten it, and then take your dubbing, which is to make the body of your fly, as much as you think convenient, and holding it lightly with your hook betwixt the finger and thumb of your left hand, take your silk with the right, and twisting it betwixt the finger and thumb of that hand, the dubbing will spin itself about the silk, which when it has done, whip 
it about the armed hook backward, till you come to the setting on of the wings, and then take the feather for the wings, and divide it equally into two parts, and turn them back towards the bend of the hook, the one on the one side and the other on the other of the shank, holding them fast in that posture betwixt the fore-finger and thumb of your left hand; which done, warp them so down as to stand and slope towards the bend of the hook ; and having warped up to the end of the shank, hold the fly fast betwixt the finger and thumb of your left hand, and then take the silk betwixt the finger and thumb of your right hand, and where the warping ends, pinch or nip it with your thumb-nail against your finger, and strip away the remainder of your dubbing from the silk, and then with the bare silk whip it once or twice about, make the wings to stand in due order, fasten, and cut it off; after which, with the point of a needle, raise up the dubbing gently from the warp, twitch off the superfluous hairs of your dubbing; leave the wings of an equal length, your fly will never else swim true, and the work is done. And this way of making a fly, which is certainly the best of all other, was taught me by a kinsman of mine, one Captain Henry Jackson, a near neighbour, an admirable flyangler, by many degrees the best fly-maker that ever I yet met with." And now that I have told you how a fly is to be made, you shall presently see me make one, with which you may peradventure take a trout this morning, notwithstanding the unlikeliness of the day; for it is now nine of the clock, and fish will begin to rise, if they will rise to-day: I will walk along by you, and look on, and after dinner I will proceed in my lecture of fly-fishing.

VIAT. I confess I long to be at the river, and yet I could sit here all day to hear you : but some of the one, and some of the other, will do well ; and I have a mighty ambition to take a trout in your river Dove.

Pisc. I warrant you shall: I would not for more than I

* There needs nothing more be said of these directions, than that hundreds have, by means of them alone, become excellent fly-makers.- $\mathrm{H}$.

[NOTE.-I cannot agree with Sir J. Hawkins. Cotton's directions are limited to making the easiest of all made flies-a fly with body and wings, but without tail, hackle-feather for legs, tinsel for tip and ribbing. In consequence, I have given diagrams of the artificial fiy in its several stages of fabrication, and have elucidated them with written descriptions and instructions. See the last pages of this work.-ED.] 
will speak of but you should, seeing I have so extolled my river to you : nay, I will keep you here a month, but you shall have one good day of sport before you go.

VIAT. You will find me, I doubt, too tractable that way; for in good earnest, if business would give me leave, and that it were fit, I could find in my heart to stay with you for ever.

PIsc. I thank you, sir, for that kind expression ; and now let me look out my things to make this fly.

[Remarks on Gut, Casting-tines; on throwing the Line and Flies; Working or "HoMouring" the latter on the Water; oN HOOKING, PLAYING, AND LANDING A TROUT.-Silk-worm gut is now used by all fly-fishers. It can be bought cheaply of all qualitiesroundness, strength, lengths of link, thickness, and fineness. The best comes from Spain : and the fresher, brighter, and rounder it is the better. It cannot be too thick or round for salmon-fishing, or too fine for trout and grayling-fishing in a clear-stream. I do not think it absolutely necessary to stain gut, but if you choose to do so, immerse it in coils in a saucer of heated good writing ink for four or five minutes, and then wash it in cold spring water. The colour communicated to the gut will be a pale bluish green. In making the gut, casting-line, or "collar," as in certain localities it is termed, the finest links should be at the end of the line that first touches the water, and then should gradually increase in thickness up to the loop by means of which the collar is fastened to the loop of the winch-line. The extreme end of the winch-line, and the upper end of the casting-line should be equal in thickness, and to render them so, a couple of feet of fine platted gut may be added to the thicker end of the casting-line. The links of which the latter is formed are knotted together-fine end to thick end-and the knots are frequently rendered more secure by being whipped neatly with waxed silk. If the links are well knotted, they will require no whipping. It is above these knots that the drop-flies, or "bobs," are attached; the tail-fly, or "stretcher," is looped to the fine end of the casting-line, whose length need never exceed two and a half yards, and on which it is rarely advisable to place more than three flies, a stretcher, and two drop-flies. The stretcher should be the largest and best fly; the first drop, a bob, the next best; and the drop-fly above that the smallest and least attractive. The distance between the stretcher and first bob should be two feet, and between the first and last bob eighteen or twenty inches. Your castingline is now complete.

At the outset-at the first lesson of throwing the line-begin with about four or five yards of the winch-line, not putting on the gut castingline until you can throw tolerably well a few yards of the winch-line. When you can do so, attach a gut collar of two yards, without any fly attached; and after you have learnt to throw that straightly eight or ten yards, you may attach your stretcher and one bob and commence angling. In "A Handbook of Angling," I have written on throwing 
the line as follows:-_" You are a beginner, I presume, and have never handled a rod before. Let the rod for your novitiate be ten or eleven feet long; its play inclining rather to faulty stiffness than to over-pliancy. Put the joints or pieces together, the rings standing in a straight line, that the winch-line may run freely through them without any tortuous impediment. Put on your winch with its handle, at first, to its left side, and draw your line through the rings, until there be four or five yards of it out beyond the final ring at the point of the top joint. Turn your rod so that the winch be on the under side, with its handle to your right hand. You are now ready for your first cast. Grasp your rod in your right hand a little above the winch, but not tightly. Your hand must not close firmly with the thumb turned over your knuckles, as if you were going to strike a blow. Your fingers must simply entwine the rod, not squeeze it, and your thumb, the flat, fleshy part downwards, must be straight with the arm, pressing the upper side of the rod, which hold up perpendicularly, and pointing a little to the left side. Take the tip of the line between the fore-finger and thumb of your left hand: poise your rod loosely and freely, and see that it balances easily in your right hand. .... I'll suppose you on a bank above some river's surface. Move your right wrist and fore-arm round to the right, letting go, just as it is beginning to get tant, the tip of the line from your left fingers, and bring round from left to right over your right shoulder the upper part of your rod, describing with the point of it an irregular-a horse-shoe-circle, and then cast forward with a flinging motion of the wrist and fore-arm. The motion, or action of the wrist must predominate over that of the fore-arm and elbow joint. If you follow the above motions exactly, and with fearless freedom, from four to five feet of the extremity of your line should fall lightly upon the surface of the water. If not, you are wrong, and you must continue practising until you are right."

To prevent too much of the line falling upon the water, do not bend your body with the east, or allow the point of your rod to descend beyond a horizontal yosition; indeed not so much, but a little between tho horizontal and perpendicular projection. "At first," as I have written in the treatise just named, " you will find, unless you be very handy, and a very apt scholar indeed, that nearly all your line out will fall upon the water, and that the point of your rod will come in contact, or nearly so, with the surface of it. These are the greatest drawbacks to throwing a line well, and if not overcome, the learner must never expect to become an expert fly-fisher. With might and main he must struggle to vanquish them. They are caused by letting the fore-arm fall too low whilst in the act of casting, and bending the body forward in unison with the downward motion of the arm. Here is the remedy. When you have made your casting movement-brought your rod and line over the shoulder and over and by the right side of your head, and propelled them forwards, the motion of the wrist and elbow joint must be gradually checked as the line is straightening itself in its onward and descending course. The body must be upright, and the chest held rather back. You will find, if you hold your rod properly, that the end of it nearest to you, the part between your hand and the spike, or spud, will come in contact with the 
under part of your fore-arm as the line is approaching the water; and this contact will prevent the point of your rod following the line so low as to cause a great part of the latter to roll on to the water."

Having practised with winch-line only, and being able to throw well ten yards of it, put on your casting-line with a single fly, and see if you cannot raise and hook a fish. There is a cast-the back-handed onewhich you must learn. It means throwing from left to right, and is done by bringing the point of your rod well up before you from right to left side; and then, turning over your hand, by the action of the wrist, from left to right, throw backwards down stream, bringing rod and line over in that direction, and sending the casting-line sharply obliquely across the water below you, on the right side. This is a good way of casting when there are obstructions, trees, rocks, high banks, behind you; and at the same time it eases your arm when fatigued with casting from the right shoulder. Being able so to cast, that your gut-line will touch the water first, bringing with it on to the surface very little of the winch-line, you may commence operations in earnest, and with three flies. In throwing a long line, the right arm motion must be no longer confined to the hand and fore-arm, but must extend to the shoulder. All the powers of the muscles of the fore, upper arm and shoulder must be brought into requisition. The arm must be brought round in a full easy sweep until the hand and rod come over the shoulder, and above and by the right side of the head, and then the line and flies must be sent forwards with a vigorous fling.

The flies are humoured on the water with the current, and not against it, as they are humoured in fishing for salmon. Throw them obliquely from you across the stream, and work them downwards, giving them motion by tremulous action of the wrist, and working them with the current; and the line having floated to its tightened length, work the flies across strean, but not against it, until they have nearly reached the bank below on your side. Take them then from the water, and repeat the cast either above or below the previous one-above, if you are fishing a river upwards; below, if you are fishing downwards, or with the flow of the water. Anglers disagree on the question of fishing up and down stream. In my opinion, it is better to begin fishing towards the tail of a stream, finishing at its head, for by so doing fewer fish are disturbed than by the effects that follow commencing at the head of a pool, swim, or stream. A hooked-fish generally runs down stream, and will disturb the fish before him. If, fishing up stream, you have already thrown over fish above you without raising them, their being disturbed or frightened by the struggling hooked-fish will be of no consequence. Having already refused your lures, you may leave them, for the time being at least, in their unscared tranquillity. Invariably cominence casting near the bank on which you stand, increasing the lengths of your casts until you throw as far from you as you can. If you commence with long casts, you would disturb the fish that lie in that part of the water nearest to you. The following passage, written by me six years since, has been lauded by practitioners and quoted by the best writers on angling :- "In what precise shape artificial flies floating on the water, or just beneath it, pre- 
sent themselves to the fish, I cannot truly tell. They certainly cannot present themselves in the exact living forms of natural insects, but their appearance must be something similar. If I were to guess, I should say that the artificial flies for the common trout, grayling, and some of the carp tribe, present the appearance of drowning, or drowned natural flies - of living insects struggling on, or a little beneath the surface of the water. I do not think this surmise fanciful. At any rate, the flyfisher should endeavour to present his artificial baits to the fish as deceptively as possible, namely, by giving them as natural an appearance as may be. He must cause them to drop lightly on the water, becausethe natural fly does so ; he must cause them to float down stream as near the surface as he can, because the natural fly moves upon the surface of the water; and he must impart tremulous, or fitful motion to his fliesa sort of fluttering, generally speaking, being the best. All this is comprehended by the expression 'humouring' one's flies. To do it, the moment your flies alight upon the water, hold up your rod, so that the drop-fly next to it may appear skimming the surface; the other two, if properly proportioned and attached to the casting-line, being ever so little under water. If you allow your upper dropper to be under water, all the flies on the line below that dropper will be sunk too deeply to appear living insects to the fish, and therefore any motion you may give them will not be attractive. When you keep your last dropper (second fly from the stretcher or tail-fly) on the surface of the water, impart to it a very slight skipping motion, by a tremulous shake of the rod, and the flies that are just under water will receive the most natural movements you can give them. Never drag your trout-flies straight across the water towards you; and never, unless they be flies for salmon or sea-trout, work them against the current."

When a fish rises to the fly, do not strike rapidly or roughly. A gentle, obliquely upwards twist of the wrist, made the moment you feel your fish, will be sufficient to hook him. Strike not at a rise, but a little after it; and not at all, unless sensation tells you the fish has touched or seized the fly. If a fish rises and misses the fly, and you strike at him, thereby whipping the fly unnaturally away from him, he will hardly be tempted to rise again; but if you do not, and go on humouring your flies until it be necessary to make another cast, in all probability the trout will come again. When hooked, do not lean heavily on your fish, but let him go, holding him in hand, with an upright rod, and taut, but not pulling, line. Of such a line give him enough; for the more of it he has to swim away with and carry, the sooner will he be exhausted -when you feel that he is, wind up your winch-line slowly, presenting the butt of the rod towards the fish, and the latter will yield, and come torvards you. If he be a small fish, lift him out of the water by an easy, long, upwards jerk in the clirection of the shore. If large, lead him gently, head foremost, towards your sunken landing-net; and when his head and shoulders are within the hoop of the net, lift it up, and you have a captive past escaping. Never thrust, nor let your attendant thrust, the net at the fish, lest, scared at such rude proceeding, he break away by the force of a fierce final struggle, or lest he or the line be 
struck by the net, and so cause a prompt and lasting dissolution of partnership. If a fish, as soon as hooked, commences struggling on the surface of the water, or throws jump after jump out of it, it is a sure sign that he is not firmly hooked. At each jump, lower a little the point of your rod; do not pull whilst the fish is struggling on the surface, or bounding up beyond it. Play him with delicacy; and instead of tearing away the hook from a slight hold, you may succeed in rendering that hold firmer. When a fish, on being hooked, sinks rapidly to the bottom, depend upon it he is well hooked. Play him with confidence, but not with brute force, and he cannot escape. In foul parts of the river, amongst rocks, roots of trees, near dilapidated weirs, close above them, or the arches of bridges, you must work with a tight rein, and "butt" your foe determinedly every time he makes a rush for some dangerous locality, with the intention of making it a vantage ground for a successful sauve qui peut on his part.

[If the reader study these instructions, together with those on hooking, playing, \&c., a salmon, given at the end of Chap. VII., Part I., and practise them carefully, the result will be- "Jack is as good as his master." -ED.]

\section{CHAPTER VI.}

[天rcond 1 国an.]

Pisc. Boy, come, give me my dubbing-bag here presently ; and now, sir, since I find you so honest a man, I will make no scruple to lay open my treasure before you.

VIAT. Did ever any one see the like! What a heap of trumpery is here! Certainly never an angler in Europe has his shop half so well furnished as you have.

Pisc. You, perhaps, may think now, that I rake together this trumpery, as you call it, for show only; to the end that such as see it, which are not many I assure you, may think me a great master in the art of angling : but, let me tell you, here are some colours, as contemptible as they seem here, that are very hard to be got; and scarce any one of them which, if it should be lost, I should not miss, and be concerned about the loss of it, too, once in the year. But look you, sir, amongst all these I will choose out these two colours only, of which, this is bear's hair, this darker, no great matter what ; but I am sure I have killed a great deal of fish with it ; 
and with one or both of these you shall take trout or grayling this very day, notwithstanding all disadvantages, or my art shall fail me.

VIAT. You promise comfortably, and I have a great deal of reason to believe everything you say ; but I wish the fly were made, that we were at it.

Prsc. That will not be long in doing: and pray observe then. You see first how I hold my hook, and thus I begin. Look you, here are my first two or three whips about the bare hook; thus I join hook and line; thus I put on my wings ; thus I twirl and lap on my dubbing ; thus I work it up towards the head; thus I part my wings ; thus I nip my superfluous dubbing from my silk; thus fasten; thus trim and adjust my fly; and there's a fly made; and now how do you like it?

VIAT. In earnest, admirably well, and it resembles a fly: but we about London, make the bodies of our flies both much bigger and longer, so long as even almost to the very beard of the hook.

Prsc. I know it very well, and had one of those flies given me by an honest gentleman, who came with my father Walton to give me a visit; which (to tell you the truth) I hung in my parlour window to laugh at: but, sir, you know the proverb, "Those who go to Rome must do as they at Rome do ;" and believe me, you must here make your flies after this fashion, or you will take no fish. Come, I will look you out a line, and you shall put it on, and try. it. There, sir, now I think you are fitted; and now beyond the further end of the walk you shall begin : I see, at that bend of the water above, the air crisps the water a little: knit your line first here, and then go up thither, and see what you can do.

VIAT. Did you see that, sir?

Pisc. Yes, I saw the fish : and he saw you too, which made him turn short. You must fish further off, if you intend to have any sport here ; this is no New River, let me tell you. That was a good trout, believe me : did you touch him?

VidT. No, I would I had, we would not have parted so. Look you, there is another: this is an excellent fly.

Prsc. That fly I am sure would kill fish, if the day were right : but they only chew at it, I see, and will not take it. Come, sir, let us return back to the fishing-house : this still water, I see, will not do our business to-day : you shall now, 
if you please, make a fly yourself,* and try what you can do in the streams with that : and I know a trout taken with a fly of your own making, will please you better than twenty witl one of mine. Give me that bag again, sirrah : look you, sir, there is a hook, towght, silk, and a feather for the wings : be doing with those, and I will look you out a dubbing that I think will do.

VIAT. This is a very little hook.

Pisc. That may serve to inform you, that it is for a very little fly, and you must make your wings accordingly ; for as the case stands, it must be a little fly, and a very little one too, that must do your business. Well said! believe me, you shift your fingers very handsomely; I doubt I have taken upon me to teach my master. So here's your dubbing now.

VIAT. This dubbing is very black.

Prsc. It appears so in hand; but step to the door and hold it up betwixt your eye and the sun, and it will appear a shining red; let me tell you, never a man in England can discern the true colour of a dubbing any way but that, and therefore chuse always to make your flies on such a bright sunshine day as this, $\uparrow$ which also you may the better do, becanse it is worth nothing to fish in : here, put it on, and be sure to make the body of your fly as tender as you can. Very good! upon my word you have made a marvellous haudsome fly.

VIAT. I am very glad to hear it; it is the first that ever I made of this kind in my life.

* To make a fly is so essential, that he hardly deserves the name of an angler who cannot do it. There are many who will go to a tackle-shop, and tell the master of it, as Dapper does Subtle, in the "Alchemist," that they want a fly; for which they have a thing put into their hands that would pose a naturalist to find a resemblance for: though, when particular directions have been given, I have known them excellently made by the persons employed by the fishing-tackle makers in London. But do thou, my honest friend, Jearn to make thy own flies; and be assured, that in collecting and arranging the materials, and imitating the various shapes and colours of these admirable creatures, there is little less pleasure than even in catching fish.-H.

[NотE.-All this is changed now. The flies sold in the Iondon tackle-shops are generally good, and in some very good. Those made by Blacker, of 54, Dean-street, Soho, cannot be equalled; and the flies of Messrs. Bowness, Bellyard, Mr. Bernard, Church-place, Piccadilly, of Mr. C. Farlow, 191, Strand, and $\mathrm{Mr}$. Little, Fetter-lane, are killing ones.-ED.]

$\dagger$ Excellent advice. The colour of feathers, fur, etc., cannot be accurately ascertained, except by looking through them at the light. In mixing differently coloured bits of dubbing a good light, natural or artificial, is necessary.-ED. 
PIsc. Away, away! you are a doctor at it ; but I will not commend you too much, lest I make you proud. Come, put it on, and you shall now go downward to some streams betwixt the rocks below the little foot-bridge you see there, and try your fortune. Take heed of slipping into the water as you follow me under this rock: so, now you are over, and now throw in.

VIAT. This is a fine stream indeed :-there's one! I have him.

Prsc. And a precious catch you have of him ; pull him out! I see you have a tender hand : this is a diminutive gentleman, e'en throw him in again, and let him grow till he be more worthy your anger.*

VIAT. Pardon me, sir, all's fish that comes to the hook with me now.-Another.

Pisc. And of the same standing.

VIAT. I see I shall have good sport now : another! and a grayling. Why, you have fish here at will.

PIsc. Come, come, cross the bridge, and go down the other side lower, where you will find finer streams and better sport, I hope than this. Look you, sir, here is a fine stream now, you have length enough, stand a little further off, let me entreat you, and do but fish this stream like an artist, and peradventure a good fish may fall to your share.- - How now! what! is all gone?

VIAT. No, but I touched him; but that was a fish worth taking.

PISC. Why now, let me tell you, you lost that fish by your own fault, and through your own eagerness and haste; for you are never to offer to strike a good fish, if he do not strike himself, till you first see him turn his head after he has taken your fly, and then you can never strain your tackle in the striking, if you strike with any manner of moderation. $\downarrow$ Come, throw in once again, and fish me this stream by inches ; for I assure you here are very good fish ; both trout and grayling lie here; and at that great stone on the other side, it is ten to one a good trout gives you the meeting.

* This passage proves Cotton to have been a real sportsman. IIe contemns catching small fish, and says, "throw them in again." Viator being a novice, sees no discredit in capturing "diminutive gentlemen," and it is quite in keeping with the sentiments of a young angler to exclaim, "All's fish that comes to the hook now."-Ev.

t Pray, reader, attend to this valuable counsel. 
VIAT. I have him now, but he is gone down towards the bottom : I cannot see what he is, yet he should be a good fish by his weight; but he makes no great stir.

PIsc. Why then, by what you say, I dare venture to assure you it is a grayling, who is one of the deadest-hearted fishes in the world, and the bigger he is, the more easily taken. Look you, now you see him plain; I told you what he was: bring hither that landing-net, boy : and now, sir, he is your own ; and believe me a good one, sixteen inches long, I warrant him : I have taken none such this year.

VIAT. I never saw a grayling before look so black.

Pisc. Did you not? Why then, let me tell you, that you never saw one before in right season; for then a grayling is very black about his head, gills, and down his back; and has his belly of a dark gray, dappled with black spots, as you see this is ; and I am apt to conclude that from thence he derives his name of umber. Though I must tell you this fish is past his prime, and begins to decline, and was in better season at Christmas than he is now. But move on : for it grows towards dinner time; and there is a very great and fine stream below, under that rock, that fills the deepest pool in all the river, where you are almost sure of a good fish.

VIAT. Let him come, I'll try a fall with him. But I had thought that the grayling had been always in season with the trout, and had come in and gone out with him.

PIsc. Oh, no! assure yourself a grayling is a winter fish ; but such a one as would deceive any but such as know him very well indeed; for his flesh, even in his worst season, is so firm, and will so easily calver, that in plain truth he is very good meat at all times : but in his perfect season (which, by the way, none but an overgrown grayling will ever be), I think him so good a fish, as to be little inferior to the best trout that ever I tasted in my life.

VIAT. Here's another skipjack; and I have raised five or six more at least while you were speaking. Well, go thy way, little Dove! thou art the finest river that ever I saw, and the fullest of fish. Indeed, sir, I like it so well, that I am afraid you will be troubled with me once a year, so long as we two live.

Prsc. I am afiaid I shall not, sir: but were you once here a May or a June, if good sport would tenipt you, I should then expect you would sometimes see me; for you would then 
say it was a fine river indeed, if you had once seen the sport at the height.

VIAT. Which I will do, if I live, and that you please to give me leave. There was one, and there another.

Prsc. And all this in a strange river, and with a fly of your own making! why, what a dangerous man are you!

VIAT. I, sir: but who taught me? and as Damætas says by his man Dorus, so you may say by me,

"If any man such praises have,

What then have I, that taught the knave !"*

But what have we got here? a rock springing up in the middle of the river ! this is one of the oddest sights that ever I saw.

Pisc. Why, sir, from that piket that you see standing up

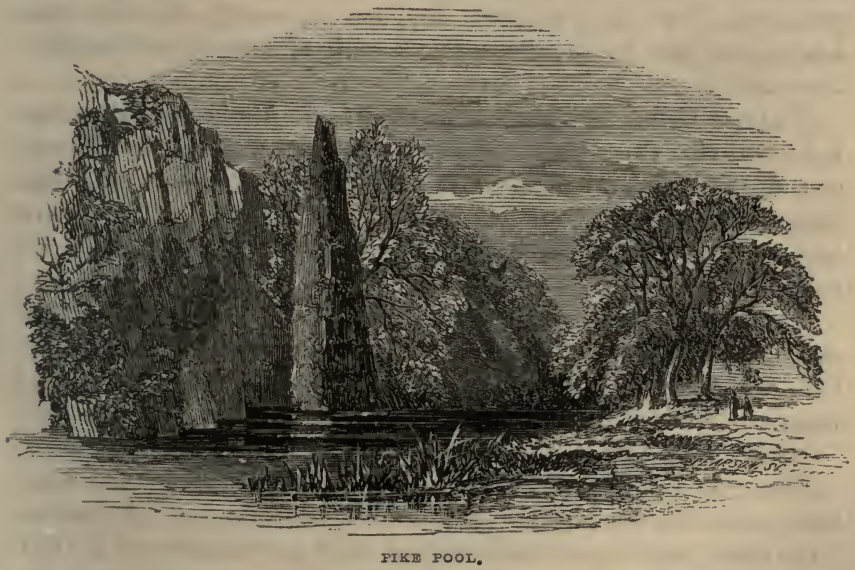

* Sidney's " Arcadia."

$\dagger$ It is a rock, in the fashion of a spire-steeple, and almost as big. It stands in the midst of the river Dove; and not far from Mr. Cotton's house; below which place this delicate river takes a swift career betwixt many mighty rocks, much higher and bigger than St. Paul's Church before it was burnt. And this Dove, being opposed by one of the highest of them, has, at last, forced itself a way through it; and after a mile's concealment, appears again with more glory and beauty than before that opposition, running through the most pleasant valleys and most fruitful meadows that this nation can justly boast of.-(WALTON, junior.)

[NOTE.-The Dove, or a branch of it, runs for a short distance under ground and debouches into daylight, a little northward of Islam Hall, the beautiful castellated mansion of Mr. Watts Russell, whose father, once a large and 
there distant from the rock, this is called Pike Pool. And young Mr. Izaak Walton was so pleased with it, as to draw it in landscape, in black and white, in a blank book I have at home, as he has done several prospects of my house also, which I keep for a memorial of his favour, and will show you when we come up to dinner.

Viat. Has young master Izaak Walton been here, too ?

PIsc. Yes, marry has he, sir, and that again and again, too, and in France since, and at Rome, and at Venice, and I can't tell where : but I intend to ask him a great many hard questions so soon as I can see him, which will be, God willing, next month. In the meantime, sir, to come to this fine stream at the head of this great pool, you must venture over these slippery, cobbling stones; believe me, sir, there you were nimble, or else you had been down; but now you are got over, look to yourself : for, on my word, if a fish rise here, he is like to be such a one as will endanger your tackle: how now!

VIAT. I think you have such command here over the fishes, that you can raise them by your word, as they say conjurers can do spirits, and afterward make them do what you bicl them, for here's a trout has taken my fly, I had rather have lost a crown.* What luck's this! he was a lovely fish, and turned up a side like a salmon.

PIsc. $\mathrm{O}$, sir, this is a war where you sometimes win, and must sometimes expect to lose. Never concern yourself for the loss of your fly, for ten to one I teach you to make a better. Who's that calls?

SERv. Sir, will it please you to come to dinner?

PIsc. We come. You hear, sir, we are called, and now take your choice, whether you will climb this steep hill before you, from the top of which you will go directly into the house, or back again over these stepping-stones, and about by the bridge.

VIAT. Nay, sure, the nearest way is best; at least my stomach tells me so; and I am now so well acquainted with your rocks, that I fear them not.

opulent soap-boiler of London, built it within the present century. Its picturegallery is one of the finest in the kingdom, and in the chapel there is a monument to the memory of the late Mrs. Watts Russell and children, by Chantrey, and considered equal to any of his other statues.-ED.]

* Not taken it in the ordinary angling acceptation, but taken it off the line -broken away with it, so that both fish and fly are lost.-ED. 
Pisc. Come, then, follow me; and so soon as we have dined, we will down again to the little house, where I will begin at the place I left off about fly-fishing, and read you another lecture; for I have a great deal more to say upon that subject.

VIAT. The more the better; I could never have met with a more obliging master, my first excepted; nor such sport can all the rivers about London ever afford, as is to be found in this pretty river.

PIsc. You deserve to have better, both because I see you are willing to take pains, and for liking this little so well; and better I hope to show you before we part.

\section{CHAPTER VII.}

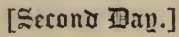

Viat. Come, sir, having now well dined, and being again set in your little house, I will now challenge your promise, and entreat you to proceed in your instruction for fly-fishing; which that you may be the better encouraged to do, I will assure you that I have not lost, I think, one syllable of what you have told me; but very well retain all your directions, both for the rod, line, and making a fly; and now desire an account of the flies themselves.

PIsc. Why, sir, I am ready to give it you, and shall have the whole afternoon to do it in, if nobody come in to interrupt us; for you must know (besides the unfitness of the day) that the aftermoons, so early in March, signify very little for angling with a fly, though with a minnow, or a worm, something might ( $\mathrm{I}$ confess) be done.

To begin, then, where I left off, my father. Walton tells us of but twelve artificial flies only, to angle with at the top, and gives their names; of which some are common with us here; and I think I guess at most of them by his description, and I believe they all breed and are taken in our rivers, though we do not make them either of the same dubbing or fashion. And it may be in the rivers about London, which I presume he has most frequented, and where it is likely he 
has done most execution, there is not much notice taken of many more : but we are acquainted with several others here, though perhaps I may reckon some of his by other names, too; but if $I$ do, I shall make you amends by an addition to his catalogue. And although the forenamed great master in the art of angling, for so in truth he is, tells you that no man should, in honesty, catch a trout in the middle of March, yet I hope he will give a man leave sooner to take a grayling, which, as I told you, is in the dead months in his best season: and do assure you (which I remember by a very remarkable token), In did once take, upon the sixth day of December, one, and only one, of the biggest graylings, and the best in season, that ever I yet saw or tasted; and do usually take trouts too, and with a fly, not only before the middle of this month, but almost every year in February, unless it be a very ill spring indeed; and have sometimes in January, so early as New-year's tide, and in frost and snow, taken grayling in a warm sunshine day for an hour or two about noon; and to fish for him with a grub, it is then the best time of all.

I shall therefore begin my fly-fishing with that month, though I confess very few begin so soon, and that such as are so fond of the sport as to embrace all opportunities, can rarely in that month find a day fit for their purpose; and tell you, that upon my knowledge these flies in a warm sun, for an hour or two in the day, are certainly taken.

\section{JANUARY.}

1. A ReD Brown, with wings of the male of a mallard almost white : the dubbing of the tail of a black long-coated cur, such as they commonly make muffs of; for the hair on the tail of such a dog dies and turns to a red-brown, but the hair of a smooth-coated dog of the same colour will not do, because it will not die, but retains its natural colour, and this fly is taken in a warm sun, this whole month through.

2. There is also a very little BRIGHT Dun GNAT, as little as can possibly be made, so little as never to be fished with, with above one hair next the hook; and this is to be made of a mixed dubbing of marten's fur, and the white of a hare's scut, with a very white and small wing; and it is no great matter how fine you fish, for nothing will rise in this month, but a grayling; and of them I never, at this season, saw any taken 
with a fly, of above a foot long in my life: but of little ones about the bigness of a smelt, in a warm day, and a glowing sun, you may take enough with these two flies, and they are both taken the whole month through.*

\section{FEBRUARY.}

1. Where the red-brown of the last month ends, another almost of the same colour begins, with this saving, that the dubbing of this must be of something a blacker colour, and both of them wrapped on with red silk. The dubbing that should make this fly, and that is the truest colour, is to be got off the black spot of a hog's ear : not that a black spot in any part of the hog will not afford the same colour, but that the hair in that place is, by many degrees, softer, and more fit for the purpose. His wing must be as the other [1. in January]; and this kills all this month, and is called the lesser red-brown.

2. This month, also, a plain hackle, or palmer-fly, made with a rough black body, either of black spaniel's fur, or the whirl of an ostrich feather, and the red hackle of a capon over all, will kill, and, if the weather be right, make very good sport.

3. Also a lesser hackle, with a black body, also silver twist over that, and a red feather over all, will fill your pannier, if the month be open, and not bound up in ice and snow, with very good fish; but, in case of a frost and snow, you are to angle only with the smallest gnats, browns, and duns you can make; and with those are only to expect graylings no bigger than sprats.

4. In this month, upon a whirling round water, we have a great hackle, the body black, and wrapped with a red feather of a capon untrimmed; that is, the whole length of the hackle staring out (for we sometimes barb the hackle-feather short all over; sometimes barb it only a little, and sometimes barb

* I do not think it necessary to describe the patterns of any trout-flies for this month. Trout are in such ill-condition now, as to be entirely worthless either for sport or food; Grayling may be caught in the middle of fine January days, with gentles, small artificial duns, and with a little "soldier palmer," made thus:-Body, bronze-coloured peacock harl, ribbed with fine gold twist, and two very small black-red, or furnace hackles, struck with strict regularity from tail to shoulder. Hooks, ten, eleven, twelve. This little palmer is a general lure for trout, dace, and roach in the summer and autumn months.-ED. 
it close underneath), leaving the whole length of the feather on the top or back of the fly, which makes it swim better, and, as occasion serves, kills very great fish.

5 . We make use, also, in this month, of another great hackle, the body black, and ribbed over with gold twist and a red feather over all; which also does great execution.

6. Also a great dun, made with dun bear's hair, and the wings of the grey feather of a mallard near unto his tail ; which is absolutely the best fly can be thrown upon a river this month, and with which an angler shall have admirable sport.

7. We have also this month the great blue dun, the dubbing of the bottom of bear's hair next to the roots, mixed with a little blue camlet, the wings of a dark grey feather of a mallard.

8. We have also this month a dark-brown, the dubbing of the brown hair off the flank of a brended cow, and the wings of the grey drake's feather.

And note, that these several hackles, or palmer-flies, are some for one water and one sky, and some for another; and, according to the change of those, we alter their size and colour; and note also, that both in this, and all other months of the year, when you do not certainly know what fly is taken, or cannot see any fish to rise, you are then to put on a small hackle, if the water be clear, or a bigger if something dark, until you have taken one; and then thrusting your finger through his gills, to pull out his gorge, which being opened with your knife, you will then discover what fly is taken, and may fit yourself accordingly.

For the making of a hackle, or palmer-fly, my father Walton has already given you sufficient direction.*

[I am not very favourable to simple lackles, or to any sort of palmers, .either in this month, or in March. I would not use palmers until April. Indeed I consider them summer and autumn baits. They are repre-

* But, with Mrr. Cotton's good leave, he has not, nor any author that I know of, unless we are to take that for a palmer, which Walton has given directions for making, page 88 , which I can never do till I see, wliat I have never yet seen, viz., caterpillars with wings. Rejecting, therefore, wings as unnatural and absurd; supposing you would make the plain hackle or palmer, which are terms of the same import, the method of doing it is as follows: So far, Sir John Hawkins. But I reject his instructions for making a hackle, and substitute my own. They will be found at the end of this work, following the plate on which are engraved diagrams of winged flies and hackle in their first, middle, and last stages of manufacture.-ED. 
scntations of caterpillars, produced in warm weather, and very rarely found in this climate of ours in April. Cotton gives a list of eight flies for February. I do not like any one of them. I will give four patterns for this month, confident of their attractiveness.

No. 1. Wings, a light brown, mottled feather of the mallard, found under its wing; body, a mixture of red squirrel's fur and claret mohair, warped up the hoop to the wings with fiery brown silk; legs, a hackledyed claret. Hooks, 8, 9, 10.

No. 2. Wings, standing upright, of a starling's wing-feather; tail, two fibres of the mottled mallard's feather; body, dark olive mohair, tipped with silver tinsel. Hooks, 9 and 10 . A good fly on a bright day.

No. 3. Wings, reddest feather of the woodcock's wing; body, dark fur of the hare's ear, to be picked out at the shoulder ; gold tip, and tail, two fibres of the mallard feather. Hooks, same size as those of No. 2.

No. 4. Wings and legs, brown mottled partridge back-feather; body, a mixture of orange mohair, and dark and light hare's ear fur. Hooks, 10 and 11.-ED.]

\section{MARCH.}

For this month you are to use all the same hackles and flies with the other: but you are to make them less.

1. We have, besides, for this month, a little dun, called a whirling dun (though it is not the whirling dun, indeed, which is one of the best flies we have); and for this the dubbing must be of the bottom fur of a squirrel's tail ; and the wing, of the grey feather of a drake.

2. Also a bright brown; the dubbing either of the brown of a spaniel, or that of a red cow's flank, with a grey wing.

3. Also a whitish dun; made of the roots of camel's hair ; and the wings, of the grey feather of a mallard.

4. There is also for this morth a fly called the thorn-tree fly ; the dubbing an absolute black, mixed with eight or ten hairs of Isabella-coloured moliair; the body as little as can be made ; of a bright mallard's feather. An admirable fly, and in great repute amongst us for a killer.

5. There is, besides this, another BuuE Dun, the dubbing of which it is made being thus to be got. Take a small-tooth comb, and with it comb the neck of a black greyhound, and the down that sticks in the teeth will be the finest blue that ever you saw. The wings of this fly can hardly be too white, and he is taken about the tenth of this month, and lasteth till the four-and-twentieth.

6. From the tenth of this month also, till towards the end, is taken a little BLACK GNAT ; the dubbing either of the fur of a black water-dog, or the down of a young black water- 
coot, the wing of the male of a mallard as white as may be, the body as little as you possibly can make it, and the wings as short as his body.

7. From the sixteenth of this month also to the end of it, we use a BRIGHT Brown; the dubbing for which is to be had out of a skinner's lime-pits, and of the hair of an abortive calf, which the lime will turn to be so bright as to shine like gold : for the wings of this fly, the feather of a brown hen is best, which fly is taken till the tenth of April.

[Trout takes flies eagerly this month, chiefly in sharp, gravelly, somewhat shallow streams. On their bottoms they lie to clean themselves by friction against sand and gravel, to feed on small fish etc., and to enjoy the watery element, more oxygenated than deep pools, by the action of a springtide sun's rays. The best flies for this month are,-

No. 1. HofLAND's FANCY.-Wings, woodeock's wing-feather; legs, bright red cóck's hackle; body, dark, brown-red floss silk; tail, two fibres of the red hackle. Hook, No. 10. This is a standard fly for all the trout streams of the metropolitan counties.

No. 2. The Red Spinner. - Wings, light brown mallard; body, searlet mohair, ribbed with thin gold wire; legs, blood-red hackle; tail, two fibres of the same. Hook, 9 and 10.

No. 3. Wings, a fieldfare's wing-feather; body, orange-coloured floss silk, over which, in close, regular laps from tail to shonlder, a furnacehackle, that is a cock's neck feather, the outer part of the fibres of which are of a pure dark red, the inner part, next the stem of the feather, being quite black. It is a most valuable feather. Hook, No. 10. An excellent general fly.

No. 4. Wings, hen pheasant's wing-feather; legs, a dun hackle, with dark bars; body, light-blue fur of the water rat, mixed with yellow mohair; tail, two fibres of the hackle used for legs. Hook, 10.

No. 5. CoCH-Y-BonddHU.-Wings, a furnace-hackle, tied buzz; legs the same feather; body short, of black ostrich and bright bronze peacock hard, twisted together; gold-tip; and hooks, 10 and 11.

No. 6. The March-Brows.-Wings, standing erect, of the hen pheasant's wing or tail-feather; body, pale orange molair mixed with reddish fur from the hare's poll; legs, a pure honey dun hackle; tail, two fibres of the pheasant's wing. Hooks, 7, 8, 9, and 10.

I consider this the best of all flies from the middle of March to the end of April, with the exception of the oak-fiy for the latter month. When the natural fly is on the water in great abundance, it is taken by trout as eagerly as the Mayfly, or green drake, in May and June. I esteem it so highly, that I will give two other ways of dressing it.

1st. BLACKER'S WAY.-Wings, hen pheasant's wing-feather or grey mottled partridge feather; body, light and dark hare's-ear fur, mixed with a little dark yellow mohair, and ribbed with pale yellow silk; legs, small brown partridge back-feather; tail, two fibres of brown mottled mallarl's feather. Hooks, 9 and 10. 
2nd. BLAine's WAY. - Wings, mottled feather from the tail of a partridge, or hen pheasant, set upriglit; body, light fur and red squirrel's fur mixed, and ribbed with yellow silk; legs, a grizzled dun-hackle, and tail, whisks of two fibres of the feather the wings are made of. Hook, No. 6.

When the natural fly was well out upon the water, and trout taking it eagerly, I would fish with three of the above patterns-one of each on the casting-line at the same time, using the largest for stretcher. -Ev.]

\section{APRIL.}

All the same hackles and flies that were taken in March will be taken in this month also, with this distinction only concerning the flies, that all the browns be lapped with red silk, and the duns with yellow.

1. To these a small Bright Brown, made of spaniel's fur, with a light grey wing, in a bright day, and a clear water, is very well taken.

2. We have too a little DARK Brown, the dubbing of that colour, and some violet camlet mixed, and the wing, of the grey feather of a mallard.

3. From the sixth of this month to the tenth, we have also a fly called the VIOLET-FLY, made of a dark violet stuff, with the wings of the grey feather of a mallard.

4. About the twelfth of this month comes in the fly called the Whirurs Dun, which is taken every day, about the midtime of day, all this month through, and, by fits, from thence to the end of June, and is commonly made of the down of the fox-cub, which is of an ash colour at the roots next the skin, and ribbed about with yellow silk; the wings, of the pale grey feather of a mallard.

5. There is also a YeLLow Dus, the dubbing of camel's hair, and yellow camlet or wool, mixed, and a white-grey wing.

6. There is also this month another Litrue Brown, besides that mentioned before, made with a very slender body, the dubbing of dark brown and violet camlet, mixed, and a grey wing, which, though the direction for the making be near the other, is yet another fly, and will take when the other will not, especially in a bright day and a clear water.

7. About the twentieth of this month comes in a fly called HoRSE-FLESH-FLY ; the dubbing of which is a blue mohair, with pink-coloured and red tammy mixed, a light coloured 
wing, and a dark brown head. This fly is taken lest in an evening, and kills from two hours before sunset till twilight, and is taken the month through.

[The above is not a bad list of flies for April-the best month in the year for fly-fishing-I mean for catehing the largest number of trout, but by no means the largest in size, and still less the highest in condition. Trout, in English rivers, are not in full season until after they have fed and fattened on the Mayfly - say from the 15th of June to the 15th of August.

The list of flies I have written for March will kill in April. Add to them the following more appropriate ones:-

No. 1. The OAK-FLY. - Wings, to lie flat, of the wing-feather of a young partridge or hen pheasant; body, yellow mohair, ribbed with dark brown silk; legs, a honey-dun hackle, lapped round thrice at the shoulder; tip, pale gold twist. Hooks, 9 and 10. This is a favourite fly of mine. In April I never fish without trying it.

No. 2. The Stone-Fly.-Wings, hen pheasant's tail-feather, dressed long and flat and full; body, large, and long, of a mixture of light hare's-ear fur and yellow-brown mohair, ribbed with yellow silk; legs, a brown-red hackle; and tail, two fibres of brown mallard. Hooks, 6, 7 , and 8. The fur near the tail should have more yellow in it than the middle or upper part of the body. A good spring-fly in small, deep, thickly wooded streams. Its reputation is greater than it deserves.

No. 3. Carshalton Cock-tait.-Wings, light fibres, standing erect, of the hen starling's wing-feather; body, light blue dun fur, taper and thin, and ribbed with yellow silk; legs, three laps of a small, pale dunhackle; tail, two fibres of the same. Hooks, 11 and 12. A capital general fly at low water.

No. 4. ALDER-FLY.-Wings, flat and two sets; lower starling's wingfeather ; upper, either landrail's wing, partridge red tail-feather, or hen pheasant's ditto ; body, either bronze coloured floss silk, or bronze peacock harl, to be dressed full and tapering; legs, black hackle; tail, two fibres of the same. Hooks, 9 and 10.

No. 5. SAXI-FLY.-Wings, sandy-coloured landrail's wing-feather; body, a mixture of brown fur from the hare's poll and orange mohair; ginger hackle for legs. Hooks, 8, 9, 10.

No. 6. Wings, light grey mottled mallard feather; body, blue mole's fur, over which, at shoulder, blood-red hackle; tail, two fibres of the mallard feather. Hooks 9 and 10 . This is a very good fly, and will also kill well with a brown-red mohair body.

The artificial baits, called palmers, are imitations of caterpillars" of various sizes and colours. They answer best in deep and somewhat sluggish streams, with banks densely wooded. I have but a poor opinion of them in rapic, clear streams, particularly mountainous ones. The following are the best :-

Black Palmer.-Body, black ostrich harl, ribbed with gold twist and black cock's long fibred hackle. Hooks, from 4 to 8 .

Browy Palmer.-Body, amber-brown mohair, ribbed with gold and 
silver twist, by which, from tail to head, a brown red cock's hackle. Hook as before.

RED PAJMET.-Body, deep red mohair, ribbed with gold twist, by which is to be wound a blood-red hackle. Hook as before.

PEACOCK Palmeri.-Body, a brilliant bronze and azure full-fibred peacock harl, ribbed closely with silver tinsel, by which a dark grizzled hackle; head, of red mohair; tying silk, red. Hook as before. If clressed full, and an inch in length, it will lure large Thames trout and chub.-ED.]

MAY.

And now, sir, that we are entering into the month of May, I think it requisite to beg not only your attention, but also your best patience; for I must now be a little tedious with you, and dwell upon this month longer than ordinary; which, that you may the better endure, I must tell you, this month deserves and requires to be insisted on ; forasmuch as it alone, and the next following, afford more pleasure to the fly-angler than all the rest: and here it is, that you are to expect an account of the green-drake, and stone-fly, promised you so long ago, and some others that are peculiar to this month, and part of the month following; aud that, though not so great either in bulk or name, do yet stand in competition with the two before-named; and so, that it is yet undecided amongst the anglers, to which of the pretenders to the title of the MAY-FLY it does properly and duly belong; $;$ neither dare I, where so many of the learned in this art of angling are got in dispute about the controversy, take upon me to determine ; but I think I ought to have a vote amongst them, and according to that privilege, shall give you my free opinion; and peradventure when I have told you all, you may incline to think me in the right.

VIAT. I have so great a deference to your judgment in these matters, that I must always be of your opinion; and the more you speak, the faster I grow to my attention, for I can never be weary of hearing you upon this sulject.

Pisc. Why that's encouragement enough; and now prepare yourself for a tedious lecture; but I will first begin with the flies of less esteem, though almost anything will take a trout in May, that I may afterwards insist the louger upon those of

* To the Ephicmera vrulgata, now commonly called the May-fly, and green drake.-ED. 
greater note and reputation; know therefore, that the first fly we take notice of in this month, is called

1. The TuRkEY-FLY, the dubbing ravelled out of some blue stuff, and lapt about with yellow silk; the wings, of a grey mallard's feather.

2. Next, a Great Hackle or Palmer-Fly, with a yellow body ribbed with gold twist, and large wings, of a mallard's feather dyed yellow, with a red capon's hackle over all.

3. Then a BLACK FLY, the dubbing of a black spaniel's fur ; and the wings, of a grey mallard's feather.

4. After that, a Lrgre Brown, with a slender body, the dubbing twirled upon small red silk, and raised with the point of a needle, that the ribs or rows of silk may appear through; the wings, of the grey feather of the mallard.

5. Next, a LrTTue Dun, the dubbing of a bear's dun whirled upon yellow silk; the wings, of the grey feather of a mallard. head.

6. Then a Whits Gnat, with a pale wing, and a black

7. There is also in this month, a fly called the PeAcockFLY : the body made of a whirl of a peacock's feather, with a red head; and wings, of a mallard's feather.

8. We have then another very killing fly, known by the name of the Dur-cuT; the dubbing of which is a bear's dun, with a little blue and yellow mixed with it ; a large dun wing, and two horns at the head, made of the hairs of a squirrel's tail.

9. The next, is a Cow-LADY, a little fly; the body, of a peacock's feather ; the wing, of a red feather, or strips of the red hackle of a cock.

10. We have then, the Cow-DUNG-FLY ; the dubbing, light brown and yellow mixed ; the wing, the dark grey feather of a mallard. And note, that besides these above mentioned, all the same hackles and flies, the hackles only brighter, and the flies smaller, that are taken in April, will also be taken this month, as all browns and duns : and now I come to my Stone-Fly and Green-Drake, which are the matadores for trout and grayling, and in their season kill more fish in our Derbyshire rivers, than all the rest, past and to come, in the whole year besides.

But first I am to tell you, that we have four several flies which contend for the title of the May-fly; namely,- 
The Green-Drafe.

The STONE-FLY.

The BLACK-FLY, and

The little yellow MaY-FLY.

And all these have their champions and advocates to dispute and plead their priority; though I do not understand why. the two last-named should ; the first two having so manifestly the advantage, both in their beauty, and the wonderful execution they do in their season.

11. Of these the GrEeN-DRAKE comes in about the twentieth of this month, or betwixt that and the latter end; for they are sometimes sooner, and sometimes later, according to the quality of the year ; but never well taken till towards the end of this month, and the beginning of June. The STONE-FLY comes much sooner, so early as the middle of April; but is never well taken till towards the middle of May, and continues to kill much longer than the GreEN-Drake stays with us, so long as to the end almost of June ; and indeed, so long as there are any of them to be seen upon the water; and sometimes in an artificial fly, and late at night, or before sunrise in the morning, longer.

Now both these flies, and I believe many others, though I think not all, are certainly and demonstratively bred in the very rivers where they are taken : our cadis or cod-bait which lie under stones in the bottom of the water, most of them turning into those two flies, and being gathered in the husk, or crust, near the time of their maturity, are very easily known and distinguished, and are, of all other, the most remarkable, both for their size, as being of all other the biggest, the shortest of them being a full inch long or more ; and for the execution they do, the trout and grayling being much more greedy of them than of any others; and indeed the trout never feeds fat, nor comes into his perfect season, till these flies come in.

Of these the Green-Drake never discloses from his husk, till he be first there grown to full maturity, body, wings, and all ; and then he creeps out of his cell, but with his wings so crimpt and ruffled, by being prest together in that narrow room, that they are, for some hours, totally useless to him; by which means he is compelled either to creep upon the flags, sedges, and blades of grass, if his first rising from the bottom of the water be near the banks of the river, till the 
air and sun stiffen and smooth them : or, if his first appearance above water happen to be in the middle, he then lies upon the surface of the water like a ship at hull; for his feet are totally useless to him there, and he cannot creep upon the water as the STONE-FLY can, until his wings have got stiffness to fly with (if by some trout or grayling he be not taken in the interim, which ten to one he is), and then his wings stand high, and closed exact upon his back, like the butterfly, and his motion in flying is the same. His body is, in some, of a paler, in others, of a darker yellow; for they are not all exactly of a colour, ribbed with rows of green, long, slender, and growing sharp towards the tail, at the end of which he has three long small whisks of a very dark colour, almost black, and his tail turns up towards his back like a mallard; from whence, questionless, he has his name of the GrEexDRAKE. These, as I think I told you before, we commonly dape, or dibble with, and having gathered great store of them into a long draw-box, with holes in the cover to give them air (where also they will continue fresh and vigorous a night or more), we take them out thence by the wings, and bait them thus upon the hook. We first take one (for we commonly fish with two of them at a time), and putting the point of the hook into the thickest part of his body, under one of his wings, run it directly through, and out at the other side, leaving him spitted cross upon the hook; and then taking the other, put him on after the same mauner, but with his head the contrary way; in which posture they will live upon the hook, and play with their wings, for a quarter of an hour or more ; but you must have a care to keep their wings dry, both from the water, and also that your fingers be not wet when you take them out to bait them, for then your bait is spoiled.*

* The two preceding paragraphs are worthy of Cotton's reputation. They contain a good description of the natural May-fly, or Green-Drake, and teach how that fly is to be angled with in a live state. His method of making it artificially is not the best, in my judgment. I have written fully, carefully, and, I think, as accurately as may be, of the May-fly in " $\boldsymbol{\Lambda}$ IIandbook of Angling," saying of it,- " This famous fly is the opprobrium of fly-makers. Try how they will, they cannot in my opinion, imitate it well. The wings are their greatest foil. In making the body, they succeed tolerably well. Still the best imitation is defective, and, except upon certain occasions, the artificial May-fly is not a deadly bait. The natural fly used in dibbing far surpasses it. However, the imitation, faulty as it is, will kill when the natural fly is scarce on the water, as in cold, dark, windy days. The artificial fly answers best in currents, and in pools or deeps that are moved to small waves by a bluff south or west wind. The general feather used for the wings of this fly is a dappled 
Having now told you how to angle with this fly alive, I am now to tell you next how to make an artificial fly, that will so perfectly resemble him, as to be taken in a rough windy day, when no flies can lie upon the water, nor are to be found about the banks and sides of the river, to a wonder ; and with which you shall certainly kill the best trout and grayling in the river.

The artificial GrEen-DraKe, then, is made upon a large hook, the dubbing, camel's hair, bright bear's hair, the soft down that is combed from a hog's bristles, and yellow camlet, well mixed together; the body long, and ribbed about with green silk, or rather yellow, waxed with green wax : the whisks of the tail, of the long hairs of sables, or fitchet ; and the wings, of a white-grey feather of a mallard, dyed yellow, which is also to be dyed thus :

Take the root of a barbary tree, and shave it, and put to. it woody viss, with as much alum as a walnut, and boil your:

one, found on the sides under the wings of the mallard, and dyed a paleyellow-green colour. To hit the true colour is the great difficulty. How to get over it, I know not. I must be content to eite the best authoritics. First, I will take Mr. Blacker, a capital judge of colours, who dyes his feathers yellow by the following recipe:-Boil two or three handfuls of yellow wood one hour in a quart of soft water; wash the mallard feathers with soap and warm water; then boil them a short time, with a large spoonful of alum and tartar, in a little pipkin holding a pint of water; take them out, and inmerse them in your yellow decoction, and simmer slowly for an hour or two. The shorter the simmering, the paler the yellow of the feathers; take them out, and wash them in clean hard water. When there is occasion for dyeing yellow-green, add a little blue, more or less, according to the shade of green you wish to give the yellow. Mr. Ronald's 'Fly-fisher's Entomology' recommends another way for dyeing mallard's feathers for the May-fly's wings. He tells us to make a mordant, by dissolving a quarter of an ounce of alum in a pint of water, and then to slightly boil the feathers in it to get the grease out of them, after which to boil them in an infusion of fustic to procure a yellow, and then subduing the brightness of the yellow by adding a little copperas to the infusion. Having now the wing-feathers dyed, I'll tell you how to make the fly :-Body, bright yellow mohair, or floss silk, ribbed sparingly with a very thin, light bronze peacock's harl; wings, mottled feather of the mallard, dyed a pale yellow-green. They are to stand erect, and be slightly divided; legs, a couple of turns, close under the wings, of a light red ginger hackle; tail-whisks, three black hairs from a rabbit's whisker. Hooks, 6, 7, and 8. Another way: -Body, yellow-green mohair; wings, mallard's feather dyed yellow; a black head; legs, a yellowish hackle; tail, three hairs from a black bear's-skin. A third way,-Body, yellow floss silk, ribbed with brown tying silk; wings, as before; legs, a yellow, grizzled dun hackle; tail, as before; head, bronze peacock harl; and hooks as before. During the season of the May-fly, I would angle with three flies of different sizes and colours. I should then have three chances of success, and could ascertain which was the preferable fly." I think the May-fly of Ireland is of greener hue than in England. In small, well wooded rivers of mild temperature, the May-fly grows to a larger size than in exposed, wide rivers in our colder counties.-ED. 
feathers in it with rain water ; and they will be of a very fine yellow.

I have now done with the Green-drake, excepting to tell you, that he is taken at all hours during his season, whilst there is any day upon the sky; and with a made-fly I once took, ten days after he was absolutely gone, in a cloudy day, after a shower, and in a whistling wind, five-and-thirty very great trout and graylings, between five and eight of the clock in the evening, and had no less than five or six flies, with three good hairs a-piece, taken from me in despite of my heart, besides.

12. I should now come next to the Stone-fly, but there is another gentleman in my way, that must of necessity come in between, and that is the GREY-DRAKE, which in all shapes and dimensions is perfectly the same with the other, but quite almost of another colour, being of a paler and more livid yellow and green, and ribbed with black quite down his body, with black shining wings, and so diaphanous and tender, cobweb-like, that they are of no manner of use for daping; but come in, and are taken after the Green-drake, and in an artificial fly kill very well ; which fly is thus made, the dubbing of the down of a hog's bristles, and black spaniel's fur, mixed, and ribbed down the body with black silk, the whisks of the hairs of the beard of a black cat, and the wings of the black-grey feather of a mallard.

And now I come to the STONE-FLY ; but I am afraid I have already wearied your patience; which if $I$ have, I beseech you freely tell me so, and I will defer the remaining instructions for fly angling till some other time.

Viat. No, truly, sir, I can never be weary of hearing you. But if you think fit, because I am afraid I am too troublesome, to refresh yourself with a glass and a pipe, you may afterwards proceed, and I shall be exceedingly pleased to hear you.

PISC. I thank you, sir, for that motion: for, believe me, I am dry with talking : here, boy ! give us here a bottle and a glass ; and, sir, my service to you, and to all our friends in the south.

Viat. Your servant, sir; and I'll pledge you as heartily ; for the good powdered beef I eat at dinner, or something else, has made me thirsty.

[To Mr. Cotton's list of flies for May, add the following:- 
No. 1. Body, gold-coloured floss silk; wings and legs, light brown grouse hackle, from the neck of the bird. Hook, 10. This is the grouse-hackle, and is a good summer fly at low water.

No. 2. Body same as before; wings, grey mottled partridge tailfeather; legs, wren's tail-feather; tail, two small fibres of brown mallard. This fly should be dressed small and fine, and the body may be varied with orange; and for the Irish rivers, with green floss silk. It is an excellent summer fly, and good for grayling in autumn.

No. 3. Wings short, and to stand erect, of the yellow feather found under the wings of the thrush and redstart; body, light buff fur; legs, a very short fibred yellow dun hackle; tail, two fibres of the same. Hooks, 12 and 13. This is the little May-fly, Yellow Sally or Castlefly. It appears a week or ten days earlier in May than the Green-drake and kills well of mornings and evenings.

No. 4. BLUE-BOTTLE.-Wings, starling's clear wing-feather, to lie flat; body, stone-blue floss silk, to be thick and short, and tipped with gold tinsel; black hackle under shoulder for legs. Hooks, 8, 9, and 10. Trout take it freely on fine evenings, as a sort of dessert after a full dinner on the Green-drake. It is a good summer-fly for chub.

No. 5. THE WASP-FLY. -Wings, hen pleasant's wing-feather; body, light orange mohair, wound in separate circles from tail to shoulder, between circles, a ribbing of black ostrich harl; legs, three turns at shoulder of a light brown-red hackle; head, bronze peacock harl. Hooks, $6,7,8$. A capital fly for large tront in deep currents, or in pools ruffled by the wind.

For very fine May evenings, and for those of the summer and early autumn months, there are three standard flies, called "owl-flies," from their wings, I suppose, being made of the feathers of different coloured owls.

The first, which should be used early in the evening, has its body of any soft brown fur ; two sets of wings ; under ones, of the soft feather of a brown owl; and upper ones, of a dark brown mottled mallard feather; legs, a long-fibred ginger hackle, lapped behind the wings to make neck and heal. Hooks, 5 to 8.

The second, to be used during twilight, has a body made of creamcolour fur, and its wings of soft owl-feather of the same colour; ginger hackle under and behind wings. Hook, as before.

The third, fit for angling at night, is made of white ostrich harl, dressed full; wings, of the feather of a nearly white owl; legs, white hen's hackle; and brown head. Hook, as before.-ED.]

\section{CHAPTER VIII.}

\section{[รีtonช 田an.]}

ViAT. So, sir, I am now ready for another lesson, so soon as you please to give it me. 
Pisc. And I, sir, as ready to give you the best I can. Having told you the time of the STONE-FLy's coming in, and that he is bred of a cadis in the very river where he is taken, I am next to tell you that,

13. 'This same STONE-FLY has not the patience to continue in his crust, or husk, till his wings be full grown; but so soon as ever they begin to put out, that he feels himself strong, (at which time we call him a jack) squeezes himself out of prison, and crawls to the top of some stone, where, if he can find a chink that will receive him, or can creep betwixt two stones, the one lying hollow upon the other, which, by the way, we also lity so purposely to find them, he there lurks till his wings be full grown, and there is your only place to find him, and from thence doubtless he derives his name; though, for want of such convenience, he will make shift with the hollow of a bank, or any other place where the wind cannot come to fetch him off. His body is long, and pretty thick, and as broad at the tail almost as in the middle; his colour a very fine brown, ribbed with yellow, and much yellower on the belly than the back; he has two or three whisks also at the tag of his tail, and two little horns upon his head; his wings, when full grown, are double, and flat down his back, of the same colour, but rather darker than his body, and longer than it, though he makes but little use of them; for you shall rarely see him flying, though often swimming and paddling with several feet he has under his belly, upon the water, without stirring a wing: but the Drake will mount steeple-high into the air, though he is to be found among flags and grass, too, and indeed everywhere high and low, near the river ; there being so many of them in their season, as, were they not a very inoffensive insect, would look like a plague ; and these drakes, since I forgot to tell you before, I will tell you here, are taken by the fish to that incredible degree, that, upon a calm day, you shall see the still deeps continually all over circles by the fishes rising, who will gorge themselves with those flies, till they purge again out of their gills; and the trouts are at that time so lusty and strong, that one of eight or ten inches long, will then more struggle, and tug, and more endanger your tackle, than one twice as big in winter; but pardon this digression.

This Stone-FLy then, we dape or dibble with, as with the Drake, but with this difference, that whereas the GrEENDRAKE is common both to stream and still, and to all hours 
of the day, we seldom dape with this but in the streams (for in a whistling wind a made-fly in the deep is better), and rarely, but early and late, it not being so proper for the midtime of the day; though a great grayling will then take it very well in a sharp stream, and here and there, a trout too, but much better towards eight, nine, ten, or eleven of the clock at night, at which time also the best fish rise, and the later the better, provided you can see your fly; and when you cannot, a made-fly will murder, which is to be made thus: the dubbing of bear's dun, with a little brown and yellow camlet very well mixed, but so placed that your fly may be more yellow on the belly and towards the tail, underneath, than in any other part; and you are to place two or three hairs of a black cat's beard on the top of the hook, in your arming, so as to be turned up when you warp on your dubbing, and to stand almost upright, and staring one from another; and note, that your fly is to be ribbed with yellow silk; and the wings long, and very large, of the dark grey feather of a mallard.

14. The next May-fly is the BLACK-FLY; made with a black body, of the whirl of an ostrich-feather, ribbed with silver-twist, and the black hackle of a cock over all ; and is a killing fly, but not to be named with either of the other.

15. The last May-fly (that is, of the four pretenders), is the: little YeLLOW MAY-FLY; in shape exactly the same with the GrenN-DRAKE, but a very little one, and of as bright a yellow as can be seen; which is made of a bright yellow camlet, and the wings of a white-grey feather died yellow.

16. The last fly for this month (and which continues all June, though it comes in the middle of May), is the fly called the CAMLET-FLY, in shape like a moth, with fine diapered or water wings, and with which, as I told you before, I sometimes used to dibble; and grayling will rise mightily at it. But the artificial fly,-which is only in use amongst our. anglers, - is macle of a dark brown shining camlet, ribbed over with a very small light green silk, the wings of the double grey feather of a mallard ; and it is a killing fly for. small fish ; and so much for May.

JUNE.

From the first to the four-and-twentieth, the GREEN-DKAKE and STONE-FLY are taken, as I told you before.

1. From the twelfth to the four-and-twentieth, late at. 
night, is taken a fly, called the OwL-FLx, the dubbing of a white weasel's tail, and a white grey wing.*

2. We have then another dun, called the BARM-FLY, from its yeasty colour, the dubbing of the fur of a yellow-dun cat, and a grey wing of a mallard's feather.

3. We have also a HAckLE with a purple body, whipt about with a red capon's feather.

4. As also a Gold-Twist Hackle, with a purple body, whipt about with a red capon's feather.

5. To these we have this month a FLESH-FLY, the dubbing of a black spaniel's fur, and blue wool mixed, and a grey wing.

6. Also another little flesh-fly, the body made of the whirl of a peacock's feather, and the wings of the grey feather of a drake.

7. We have then the PEACOCK-FLY, the body and wing both made of the feather of that bird.

8. There is also the flying-ant or ANT-FLY, the dubbing of brown and red camlet mixed, with a light grey wing.

9. We have likewise a Brown GNaT, with a very slender body of brown and violet camlet well mixed, and a light grey wing.

10. And another little Black GNat, the dubbing of black mohair, and a white grey wing.

11. As also a GreEn Grasshopper, the dubbing of green and yellow wool mixed, ribbed over with green silk, and a red capon's feather over all.

12. And, lastly, a little Dun Grasshopper; the body slender, made of a dun camlet and a dun hackle at the top.

[Nearly all the flies I have described for May will kill in June, for which the three following are appropriate :-

No. 1. DARK MACKEREL_-Wings, dark-brownmottled mallard feather; body, deep mulberry-coloured floss silk, ribbed with gold tinsel; legs, purple hackle; tail, three black rabbit's whiskers. Hooks, 9 and 10.

No. 2. ORI-FLY.-Wings, reddest fibres of landrail, to lie flat and long; body, and alternate ribbing of dark brown and orange mohair; horns, two brown hackle fibres. Hooks, 8 and 9.

No. 3. Wings and legs, a very small dun hackle, wound over a body made of a mixture of blue-dun and orange-coloured mohair. Hooks, 11 and 12. A general killer in low, clear water in summer and autumn.-ED.]

* This artificial_white moth will be taken at night during June, July, and August.-ED. 
JULY.

First, all the small flies that were taken in June are also taken in this month.

1. We have then the OrANGE-FLY; the dubbing of orange wool, and the wing of a black feather.

2. Also a little WHITE-DUN ; the body made of white mohair, and the wings blue, of a heron's feather.

3. We have likewise this month a WASP-FLY ; made either of a dark brown dubbing, or else the fur of a black cat's tail, ribbed about with yellow silk; and the wing, of the grey feather of a mallard.

4. Another fly taken this month is a Black HACKLE; the body made of the whirl of a peacock's feather, and a black hackle-feather on the top.

5. We have also another, made of a peacock's whirl, without wings.

6. Another fly also is taken this month, called the SHeLLFLY ; the dubbing of yellow-green Jersey wool, and a little white hog's-hair mixed, which I call the PALM-FLY, and do believe it is taken for a palm, that drops off the willows into the water; for this fly $\bar{I}$ have seen trouts take little pieces of moss, as they have swam down the river ; by which I conclude that the best way to hit the right colour is to compare your dubbing with the moss, and mix the colours as near as you can.

7. There is also taken, this month, a Black-BLUE DuN ; the dubbing of the fur of a black rabbit mixed with a little yellow ; the wings, of the feather of a blue pigeon's wing.

[I will add to the above four very killing flies for July.

No. 1. BLACK ANT-FLY.- Wings, any light-blue feather; body, thin in the middle, but thick at shoulder and tail, resembling the body of an ant, and made of black ostrich harl; legs, two laps of very dark brown hackle, close under wings. Hook, 10.

No. 2. RED ANT-FLY.-Wings, a young starling's wing-feather; body, made of the same shape as before, but with bright bronze peacock's harl ; legs, bright red cock's hackle. Hooks, 10 and 11 . These two flies are attractive this month and the two following on dark, warm days.

No. 3. Wings, a lark's wing-feather, dyed a pale yellow; body, yellow martin's fur; legs, a small honey-dun hackle. Hook, 12. A famous summer fly at low and clear water.

No. 4. Wings, top fibres of the hen-pheasant's wing; body, brown mohair mixed with a little bright-coloured hare's-ear fur; legs, grey throat-feather of the partridge. Hooks, 11 and 12.-ED.] 


\section{AUGUST.}

The same flies with July.

1. Then another ANT-FLY, the dubbing of the black brown hair of a cow, some red wrapt in for the tug of his tail, and a dark wing; a killing fly.

2. Next a fly called the Fern-FLY, the dubbing of the fur of a hare's neck, that is, of the colour of fern, or bracken, with a darkish grey wing of a mallard's feather; a killer, too.

3. Besides these we have a White HAckle, the body of white mohair, and wrapped about with a white hackle-feather, and this is assuredly taken for thistle-down.

4. We have also this month a HARRY-LONG-LEGS, the body made of bear's dun, and blue wool mixt, and a brown hacklefeather over all.

Lastly, In this month all the same Browss and Duvs are taken that were taken in May.

[Small brown and black palmers will kill well this month. The two following are standard patterns for August :-

No. 1. Wings, fibres of a brown hen's wing-feather; body, brown floss silk, ribbed with bright yellow tying silk; legs, brown hackle; tail, two hairs of a black rabbit's whiskers. Hook, 10 .

No. 2. Body, cinnamon-brown mohair; wings, reddish feather of woodcock's wing; legs, cinnamon hackle. Hook, as before.-ED.]

\section{SEPTEMBER.}

This month the same flies are taken that are taken in April.

1. To which I shall only add a CAMIEL-Brown-FLY, the dubbing pulled out of the lime of a wall, whipped about with red silk, and a darkish grey mallard's feather for the wing.

2. And one other for which we have no name; but it is made of the black hair of a badger's skin, mixed with the yellow softest down of a sanded hog.

OCTOBER.

The same flies are taken this month as were taken in March.

\section{NOVEMBER.}

The same flies that were taken in February are taken this month also.

[For October and November, I would recommend small duns, and some 
of the flies named for April. For September, and for July and August, I recommend five flies of great attractiveness :-

No. 1. Wings, a mixture of the fibres of the red and gray tail-feathers of the partridge; body, cinnamon-brown mohair; legs, an amber-dyed hackle, from tail to wings ; tail, two fibres of the hackle. Hook, 10.

No. 2. Wings, starling's feather; body, golden olive mohair; legs, hackle of the same colour; gold tip. Hook, as before.

No. 3. Wings, a mixture of the starling's wing feather and partridge grey tail-feather; body, bronze harl, with an orange floss silk tag, gold tip; legs, black-red hackle. Hook, 8 and 10. This fly is named the "Governor."

No. 4. Wings, the top, beautiful green fibres of the peacock's moonfeather; body, bright bronze peacock's harl; legs, sometimes a furnace hackle, at others a pure black one. Hook, 10 and 11.

No. 5. Wings, a mixture of starling's wing, and brown mottled mallard feather ; body, olive-green mohair ; legs, hackle of same colour, and gold tip. Hook, as before.

Reader, I have now added to Cotton's monthly lists of trout and grayling flies, the very best modern patterns. I have fished, in my time, with the great majority of them. I know by experience their captivating qualities, and I recommend them confidently to all fly-fishers for fresh water salmonidæ.-Ev.]

\section{DECEMBER.}

Few men angle with the fly this month, no more than they do in January ; but yet, if the weather be warm (as I have known it sometimes in my life to be, even in this cold country, where it is least expected), then a Brows, that looks red in the hand, and yellowish betwixt your eye and the sun, will both raise and kill in a clear water and free from snowbroth ; but, at the best, it is hardly worth a man's labour.

And now, sir, I have done with fly-fishing, or angling at the top, excepting once more, to tell you, that of all these (and I have named you a great many very killing flies), none are fit to be compared with the DrAKe and STONE-FLY, both for many and for very great fish; and yet there are some days that are by no means proper for the sport. And in a calm you shall not have near so much sport, even with daping, as in a whistling gale of wind, for two reasons, both because you are not then so easily discovered by the fish, and also because there are then but few flies that can lie upon the water; for where they have so much choice, you may easily imagine they will not be so eager and forward to rise at a bait, that both the shadow of your body, and that of your rod, nay of your very line, in a hot calm day, will, in spite 
of your best caution, render suspected to them; but even then, in swift streams, or by sitting down patiently behind a willow bush, you shall do more execution than at almost any other time of the year with any other fly; though one may sometimes hit of a day, when he shall come home very well satisfied with sport with several other flies: but with these two, the GreEN-DRAKE and the STONE-FLY, I do verily believe I could, some days in my life, had I not been weary of slaughter, have loaden a lusty boy; and have sometimes, I do honestly assure you, given over upon the mere account of satiety of sport; which will be no hard matter to believe, when I likewise assure you, that with this very fly, I have in this very river that runs by us, in three or four hours taken thirty, five-and-thirty, and forty of the best trouts in the river. What shame and pity it is, then, that such a river should be destroyed by the basest sort of people, by those unlawful ways of fire and netting in the night, and of damming, groping, spearing, hanging, and hooking by day, which are now grown so common, that, though we have very good laws to punish such offenders, every rascal does it, for ought I see, impunè.

To conclude, I cannot now in honesty but frankly tell you, that many of these flies I have named, at least so made as we make them here, will peradventure do you no great service in your southern rivers; and will not conceal from you, but that I have sent flies to several friends in London, that for ought I could ever hear, never did any great feats with them; and therefore if you intend to profit by my instructions, you must come to angle with me here in the Peak ; and so, if you please, let us walk up to supper, and to-morrow, if the day be windy, as our days here commonly are, 'tis ten to one but we shall take a good dish of fish for dinner.

CHAPTER IX.

[Thiro 还an.]

Pisc. A good day to you, sir; I see you will always be stirring before me.

VIAT. Why, to tell you the truth, I am so allured with the 
sport I had yesterday, that I long to be at the river again; and when $I$ heard the wind sing in my chamber window, could forbear no longer, but leapt out of bed, and had just made an end of dressing myself as you came in.

Pisc. Well, I am both glad you are so ready for the day, and that the day is so fit for you; and look you, I have made you three or four flies this morning; this silver-twist hackle, this bear's dun, this light brown, and this dark brown, any of which I dare say will do; but you may try them all, and see which does best; only I must ask your pardon that I cannot wait upon you this morning, a little business being fallen out, that for two or three hours will deprive me of your eompany: but I'll come and call you home to dinner, and my man shall attend you.

VIAT. Oh, sir, mind your affairs by all means. Do but lend me a little of your skill to these fine flies, and, unless it have forsaken me since yesterday, I shall find luck of my own, I hope, to do something.

PISc. The best instruction I can give you is, that seeing the wind curls the water, and blows the right way, you would now angle up the still deep to-day; for betwixt the rocks where the streams are, you will find it now too brisk; and besides, I would have you take fish in both waters.

VIAT. I'll obey your direction, and so good morning to you. Come, young man, let you and I walk together. But hark you, sir, I have not done with you yet; I expect another lesson for angling at the bottom, in the afternoon.

Prsc. Well, sir, I'll be ready for you.

\section{CHAPTER X.}

\section{[שjúr Dan.]}

Pisc. Oh, sir, are you returned? you have but just prevented me. I was coming to call you.

VIAT. I am glad then I have saved you the labour.

Pisc. And how have you sped?

VIAT. You shall see that sir, presently; look you, sir, here are three brace of trouts, one of them the biggest but one that ever I killed with a fly in my life; and yet I lost a bigger than that, with my fly to boot; and here are three 
graylings, and one of them longer by some inches than that I took yesterday, and yet I thought that a good one, too.

PIsc. Why you have made a pretty good morning's work on't ; and now, sir, what think you of our river Dove?

VIAT. I think it to be the best trout river in England; and am so far in love with it, that if it were mine, and that I could keep it to myself, I would not exchange that water for all the land it runs over, to be totally debarred from it.

PIsc. That compliment to the river speaks you a true lover of the art of angling; and now, sir, to make part of amends for sending you so uncivilly out alone this morning, I will myself dress you this dish of fish for your dinner; walk but into the parlour, you will find one book or other in the window to entertain you the while, and you shall have it presently.

VIAT. Well, sir, I obey you.

Pisc. Look you, sir, have I not made haste?

Viat. Believe me, sir, that you have; and it looks so well, I long to be at it.

Pisc. Fall to, then; now, sir, what say you, am I a tolerable cook or no?

VIAT. So good a one, that I did never eat so good fish in my life. This fish is infinitely better than any I ever tasted of the kind in my life ; 'tis quite another thing than our trouts about London.

Pisc. You would say so, if that trout you eat of were in right season : but pray eat of the grayling, which upon $\mathrm{my}$ word, at this season is by much the better fish.

Viat. In earnest and so it is : and I have one request to make to you, which is, that as you have taught me to catch trout and grayling, you will now teach me how to dress them as these are drest, which questionless is of all other the best way.

PIsc. That I will, sir, with all my heart, and am glad you like them so well as to make that request, and they are drest thus :

Take your trout, wash, and dry him with a clean napkin ; then open him, and having taken out his guts, and all the hlood, wipe him very clean within, but wash him not, and give him three scotches with a knife to the bone, on one side only. After, which take a clean kettle, and put in as much hard stale beer (but it must not be dead) vinegar, and a little white wine and water as will cover the fish you intend 
to boil ; then throw into the liquor a good quantity of salt, the rind of a lemon, a handful of sliced horseradish root, with a handsome light faggot of rosemary, thyme, and winter savory. Then set your kettle upon a quick fire of wood: and let your liquor boil up to the height before you put in your fish : and then, if there be many, put them in one by one, that they may not so cool the liquor as to make it fall. And whilst your fish is boiling, beat up the batter for your sauce with a ladleful or two of the liquor it is boiling in. And being boiled enough, irnmediately pour the liquor from the fish : and being laid in a dish, pour your butter upon it; and strewing it plentifully over with shaved horseradish, and a little pounded ginger, garnish the sides of your dish, and the fish itself, with a sliced lemon or two, and serve it up.

A grayling is also to be dressed exactly after the same manner, saving that he is to be scaled, which a trout never is : and that must be done either with one's nails, or very lightly and carefully with a knife, for fear of bruising the fish. And note, that these kinds of fish, a trout especially, if he is not eaten within four or five hours after he be taken, is worth nothing.

But come, sir, I see you have dined ; and therefore, if you please, we will walk down again to the little house, and there I will read you a lecture of angling at the bottom.

\section{CHAPTER XI.}

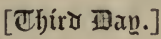

VIAT. So, sir, now we are here, and set, let me have my instructions for angling for trout and grayling at the bottom ; which though not so easy, so cleanly, nor (as 'tis said) so genteel a way of fishing as with a fly, is yet, if I mistake not, a good holding way, and takes fish when nothing else will.

Pisc. You are in the right, it does so : and a worm is so sure a bait at all times, that, excepting in a flood, I would I had laid a thousand pounds that I killed fish, more or less with it, winter or summer, every day throughout the year; those days always excepted, that upon a more serious account al ways ought so to be. But not longer to delay you, I will begin, and tell you, that angling at the bottom is also commonly of two sorts; and yet there is a third way of angling 
with a ground-bait, and to very great effect too, as shall be said hereafter; namely, by hand, or with a cork or float.

That we call angling hy hand is of three sorts.

The first, with a line about half the length of the rod, a good weighty plumb, and three hairs next the hook, which we call a running-line, and with one large brandling, or a dew-worm of a moderate size, or two small ones of the first, or any other sort, proper for a trout, of which my father Walton has already given you the names, and saved me labour ; or, indeed, almost any worm whatever ; for if a trout be in the humour to bite, it must be such a worm as I never yet saw, that he will refuse; and if you fish with two, you are then to bait your hook thus. You are first to run the point of your hook in at the very head of your first worm, and so down through his body, till he be past the knot, and then let it out, and strip the worm above the arming, that you may not bruise it with your fingers till you have put on the other, by running the point of the hook in below the knot, upwards through his body towards his head, till it be just covered with the head; which being done, you are then to slip the first worm down over the arming again, till the knots of both worms meet together.

The second way of angling by hand, and with a running line, is with a line something longer than the former, and with tackle made after this same manner. At the utmost extremity of your line, where the hook is always placed in all other ways of angling, you are to have a large pistol or carabine bullet, into which the end of your line is to be fastened with a peg or pin, even and close with the bullet; and, about half a foot above that, a branch of line, of two or three handfuls long, or more for a swift stream, with a hook at the end thereof, baited with some of the fore-named worms, and, half a foot above that, another armed and baited after the same manner, but with another sort of worm, without any lead at all above: by which means you will always certainly find the true bottom in all depths; which with the plumbs upon your line above you can never do, but that your bait must always drag whilst you are sounding (which in this way of angling must be continually), by which means you are like to have more trouble, and peradventure worse success. And both these ways of angling at the bottom are most proper for a dark and muddy water, by reason, that in such a condition of the stream, a man may 
stand as near as he will, and neither his own shadow nor the roundness of his tackle will hinder his sport.

The third way of angling by hand with a ground-bait, and by much the best of all other, is, with a line full as long, or a yard and a half longer, than your rod; with no more than one hair next the hook, and for two or three lengths above it ; and no more than one small pellet or shot for your plumb ; your hook, little; your worms of the smaller brandlings, very well secured, and only one upon your hook at a time; which is thus to be baited. The point of your hook is to be put in at the very tag of his tail, and run up his body quite over all the arming, and still stripped on an inch at least upon the hair, the head and remaining part hanging downward : and with this line and hook thus baited you are evermore to angle in the streams, always in a clear rather than a troubled water, and always up the river, still casting out your worm before you with a light one-handed rod, like an artificial fly; where it will be taken sometimes at the top, or within a very little of the superficies of the water, and almost always before that light plumb can sink it to the bottom, both by reason of the stream, and also, that you must always keep your worm in motion by drawing still back towards you, as if you were angling with a fly: and believe me, whoever will try it, shall find this the best way of all other to angle with a worm, in a bright water especially; but then his rod must be very light and pliant, and very true and finely made, which, with a skilful hand, will do wonders, aud in a clear stream is undoubtedly the best way of angling for a trout or grayling with a worm, by many degrees, that any man can make choice of, and of most ease and delight to the angler. To which, let me add, that if the angler be of a constitution that will suffer him to wade, and will slip into the tail of a shallow stream, to the calf of the leg, or the knee, and so keep off the bank, he shall almost take what fish he pleases.

The second way of angling at the bottom, is with a cork or float; and that is also of two sorts ; with a worm, or with a grub or cadis.

With a worm, you are to have your line within a foot, or a foot and a half as long as your rod; in a dark water, with two, or if you will with three, but in a clear water never with above one hair next the hook, and two or three for four or five lengths above it, and a worm of what size you please, 
your plumbs fitted to your cork, your cork to the condition of the river, that is, to the swiftness or slowness of it; and both, when the water is very clear, as fine as you can; and then you are never to bait with above one of the lesser sort of brandlings; or, if they are very little ones indeed, you may then bait with two, after the manner before directed.

When you angle for a trout, you are to do it as deep, that is, as near the bottom as you can, provided your bait do not drag; or if it do, a trout will sometimes take it in at that posture : if for a grayling, you are then to fish further from the bottom, he being a fish that usually swims nearer the middle of the water, and lies always loose; or however, is more apt to rise than a trout, and more inclined to rise than to descend even to a ground-bait.

With a grub or cadis, you are to angle with the same length of line, or if it be all out as long as your rod it is not the worse, with never above one hair, for two or three lengths next the hook, and with the smallest cork or float, and the least weight of plumb you can that will but sink, and that the swiftness of your stream will allow ; which also you may help, and avoid the violence of the current, by angling in the returns of a stream, or the eddies betwixt two streams, which also are the most likely places wherein to kill a fish in a stream, either at the top or bottom.

Of grubs for a grayling, the ash-grub, which is plump, milk-white, bent round from head to tail, and exceeding tender, with a red head, or the dock-worm, or grub of a pale yellow, longer, lanker, and tougher than the other, with rows of feet all down his belly, and a red head also, are the best; I say, for a grayling, because, although a trout will take both these, the ash-grub especially, yet he does not do it so freely as the other, and I have usually taken ten graylings for one trout with that bait; though if a trout come, I have observed that he is commonly a very good one.

These baits we usually keep in bran, in which an ash-grub commonly grows tougher, and will better endure baiting; though he is yet so tender, that it will be necessary to warp in a piece of a stiff hair with your arming, leaving it standing out about a straw-breadth at the head of your hook, so as to keep the grub either from slipping totally off when baited, or at least down to the point of the hook; by which means your arming will be left wholly naked and bare, which is neither so sightly, nor so likely to be taken : though to help 
that, which will however very oft fall out, I always arm thehook I design for this bait with the whitest horse-hair I can choose, which itself will resemble, and shine like that bait, and consequently will do more good, or less harm, than an arming of any other colour. These grubs are to be baited thus : the hook is to be put under the head or chaps of the bait, and guided down the middle of the belly-without suffering it to peep out by the way, for then the ash-grub especially will issue out water and milk, till nothing but the skin shall remain, and the bend of the hook will appear black, through it,- -till the point of your hook come so low that the head of your bait may rest, and stick upon the hair that stands out to hold it; by which means it can neither slip of itself, neither will the force of the stream, nor quick: pulling out, upon any mistake, strip it off.

Now the cadis, or cod-bait, which is a sure killing bait, and, for the most part, by much surer than either of the other, may be put upon the hook, two or three together, and is sometimes, to very great effect, joined to a worm, and sometimes to an artificial fly, to cover the joint of your hook; but is always to be angled with at the bottom, when by itself especially, with the finest tackle; and is, for all times of the year, the most holding bait of all other whatever, both for trout and grayling.

There are several other baits besides these few I have named you, which also do very great execution at the bottom, and some that are peculiar to certain countries and rivers, of which every angler may in his own place make his own observation; and some others that I do not think fit to put you in mind of, because I would not corrupt you, and would have you, as in all things else. I observe you to be a very honest gentleman, a fair angler. And so much for the second sort of angling for a trout at the bottom.

VIAT. But, sir, I beseech you give me leave to ask you one question : is there no art to be used to worms, to make them allure the fish, and in a manner compel them to bite at the bait?

Pisc. Not that I know of ; or did I know any such secret, I would not use it myself, and therefore would not teach it you. Though I will not deny to you, that in my younger days, I have made trial of oil of osprey, oil of ivy, camphire, assafoetida, juice of nettles, and several other devices that I was taught by several anglers I met with; but could never 
find any advantage by them; and can scarce believe there is anything to be done that way; though I must tell you, I have seen some men who I thought went to work no more artificially than I, and have yet, with the same kind of worms I had, in my own sight taken five, and sometimes ten to one. But we'll let that business alone, if you please ; and because we have time enough, and that I would deliver you from the trouble of any more lectures, I will, if you please, proceed to the last way of angling for a trout or grayling, which is in the middle; after which I shall have no more to trouble you with.

VIAT. 'Tis no trouble, sir, but the greatest satisfaction that can be : and I attend you.

[In this chapter Cotton proves himself every bit as good a bottomfisher as his so-called master and father, Walton.-ED.],

\section{CHAPTER XII.}

[Thír 哺an.]

Prsc. Angling in the middle, then, for a trout or grayling, is of two sorts; with a penk or minnow for a trout; or with a worm, grub, or cadis, for a grayling.

For the first. It is with a minnow, half a foot or a foot within the superficies of the water. And as to the rest that concerns this sort of angling, I shall wholly refer you to $\mathrm{Mr}$. Walton's directions, who is undoubtedly the best angler with a minnow in England; only, in plain truth, I do not approve of those baits he keeps in salt, unless where the living ones are not possibly to be had (though I know he frequently kills with them, and peradventure, more than with any other; nay, I have seen him refuse a living one for one of them); and much less of his artificial one; for though we do it with a counterfeit fly, methinks it should hardly be expected that a man should deceive a fish with a counterfeit fish.* Which

* Counterfeit fish, or artificial fish-baits, are now so well made, that in spinning I frequently use them in preference to the natural fish-bait; and in slightly discoloured water I always prefer them. They spin better, and will take a great many fish before they are injured, which is a great convenience, obviating the necessity of constantly, after a run or a kill, putting on a fresh bait, which you must do if you spin with the natural fish-bait. The best artificial fish-baits are made by Mr. Flinn, of Worcester.-ED. 
having said, I shall only add (and that out of my own experience), that I do believe a bull-head, with his gill-fins cut off (at some times of the year especially), to be a much better bait for a trout than a minnow, and a loach much better than that : to prove which I shall only tell you, that I have much oftener taken trouts with a bull-head or a loach in their throats, for there a trout has questionless his first digestion, than a minnow ; and that one day especially, having angled a good part of the day with a minnow, and that in as hopeful a day, and as fit a water, as could be wished for that purpose, without raising any one fish ; I at last fell to with the worm, and with that took fourteen in a very short space : amongst all which, there was not, to my remembrance, so much as one that had not a loach or two, and some of them, three, four, five, and six loaches, in his throat and stomach ; from whence I concluded, that had I angled with that bait, I had made a notable day's work of it.

But after all, there is a better way of angling with a minnow, than perhaps is fit either to teach or to practise; to which I shall only add, that a grayling will certainly rise at, and sometimes take a minnow, though it will be hard to be believed by any one, who shall consider the littleness of that fish's mouth, very unfit to take so great a bait: but it is affirmed by many, that he will sometimes do it; and I myself know it to be true; for though I never took a grayling so, yet a man of mine once did, and within so few paces of me, that $I$ am as certain of it, as I can be of anythiug I did not see, and, which made it appear the more strange, the grayling was not above eleven inches long.

I must here also beg leave of your master, and mine, not to controvert, but to tell him, that I cannot consent to his way of throwing in his rod to an over grown trout, and afterwards recovering his fish with his tackle. For though I am satisfied he has sometimes done it, because he says so, yet I have found it quite otherwise; and though I have taken with the angle, I may safely say, some thousands of trouts in my life, my top never snapt (though my line still continued fast to the remaining part of my rod by some lengths of line curled round about my top, and there fastened, with waxed silk, against such an accident), nor my hand never slacked, or slipped by any other chance, but I almost always infallibly lost my fish, whether great or little, though my hook came home again. And I have often wondered how a trout should so 
suddenly disengage himself from so great a hook as that we bait with a minnow, and so deep bearded as those hooks commonly are, when I have seen by the forenamed accidents or the slipping of a knot in the upper part of the line, by sudden and hard striking, that though the line has immediately been recorered, almost before it could be all drawn into the water, the fish cleared and gone in a moment. And yet, to justify what he says, I have sometimes known a trout, having carried away a whole line, found dead three or four days after with the hook fast sticking in him; and then it is to be supposed he had gorged it, which a trout will do if you be not too quick with him when he comes at a minnow, as sure and much sooner than a pike: and I myself have also, once or twice in my life, taken the same fish, with my own fly sticking in his chaps, that he had taken from me the day before, by the slipping of a hook in the arming. But I am very confident a trout will not be troubled two hours with any hook that has so much as one handful of line left behind with it, or that is not struck through a bone, if it be in any part of his mouth only: nay, I do certainly know that a trout, so soon as ever he feels himself pricked, if he carries away the hook, goes immediately to the bottom, and will there root, like a hog upon the gravel, till he either rub out or break the hook in the middle. And so much for this sort of angling in the middle for a trout.

The second way of angling in the middle is with a worm, grub, cadis, or any other ground-bait for a grayling; and that is with a cork, and a foot from the botton, a grayling taking it much better there than at the bottom, as has been said before; and this always in a clear water, and with the finest tackle.

To which we may also, and with very good reason, add the third way of angling by hand with a ground-bait, as a third way of fishing in the middle, which is common to both trout and grayling, and, as I said before, the best way of angling with a worm, of all other I ever tried whatever.

And now, sir, I have said all I can at present think of concerning angling for a trout and grayling, and I doubt not have tired you sufficiently; but I will give you no more trouble of this kind, whilst you stay, which I hope will be a good while longer.

VIAT. That will not be above a day longer; but if I live till May come twelvemonth, you are sure of me again, either 
with my master. Walton, or without him ; and in the mean time shall acquaint him how much you have made of me for his sake, and I hope he loves me well enough to thank you for it.

Pisc. I shall be glad, sir, of your good company at thetime you speak of, and shall be loath to part with you now; but when you tell me you must go, I will then wait upon you more miles on your way than I have tempted you out of it, and heartily wish you a good journey.

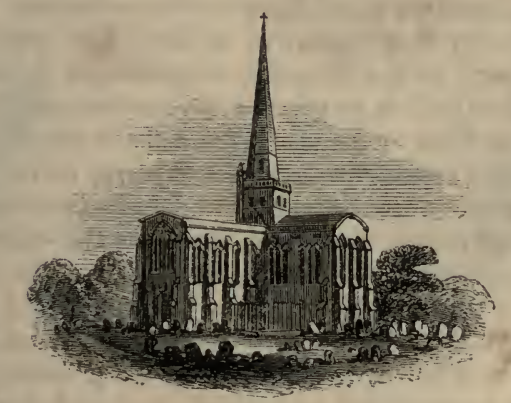

ASHBORNE CEURGE. 
IN this plate the examiner will see six representations, taken from life, of insects used in fly-fishing.

No. 1. The May-fly or Green-drake (ephemera vulgata), stands at the head of its tribe. The ephemerce are extremely numerous, of various sizes and colours, appearing particularly in the summerand autumn months. Their wingsstand upright, and they have whisks or tails. Ofall flies theseare the most useful to the angler. As their name implies, they are very short lived, but fresh tribes of them replace those which die in a day.

No. 2. Is the Stone-fly, and the largest of its tribe (phryganece). They are considered spring-flies, but they are produced throughout the year. Generally speaking they have flat wings, but that is not a specific characteristic, because the house-fly (musca) and other flies have flat wings also. The flies of this species proceed from water larvce, and in angling importance stand next to the eplemerce.

No. 3. Is the March-brown, or large dun ephemera. It is nearly as large as the May-fly, or ephemera vulgata; and in March and April is as great a favourite with trout, as the May-fly is in May or June. It is a fly I esteem very highly.

No. 4. Is a representation of a diptera, or two-winged fly. These flies are generally small, and have two upright wings. In shape and colour they much resemble the ephemerce, and as baits they are equally captivating.

No. 5. Is the Ant-fly (formica). It is a late summer and early autumn fly. Its body resembles that of an ant. Hence its name. It is not a water-born fly, but a land-bred one. Its wings are transparent and feeble, and the slightest breeze wafts it on to the surface of rivers. Grayling take it eagerly, and so do roach and dace.

No. 6. Is a dark palmer, or representation of a dark caterpillar, with light yellow circular bands round the body. Walton properly observes, "this is called a pilgrim or palmerworm, for his very wandering life and various food; not contenting himself, as others do, with any one certain place for his abode, nor any certain kind of herb or flower for his feeding; but will boldly and disorderly wander up and down, and not endure to be kept to a diet, or fixed to a particular place." As caterpillars are of various sizes and colours, so are their artificial representations. They are good angling baits in the English rivers, but not so good either in Ireland or Scotland. Chub take them with great avidity. Made very large they will catch large Thames trout, and in the rivers of South Wales they are not bad baits for Salmon. 
PLATE No. 1.

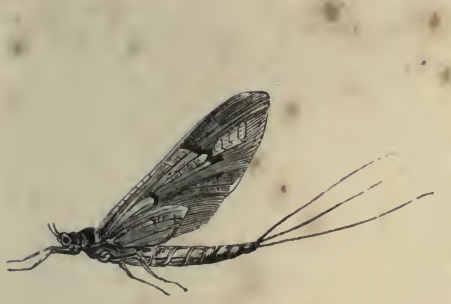

1.

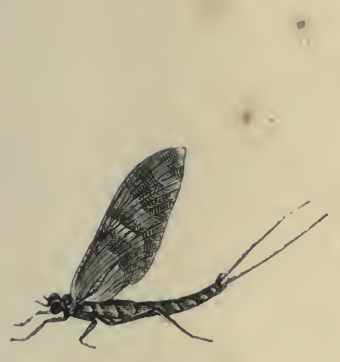

3

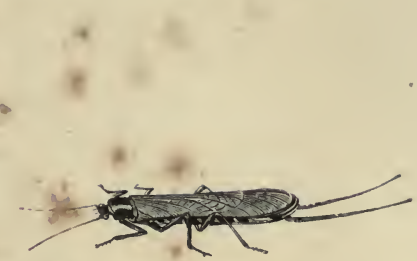

2

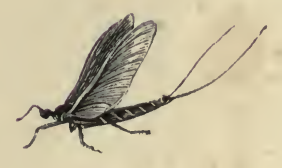

4

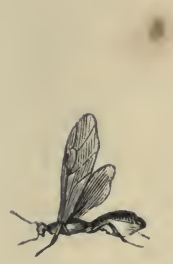

5

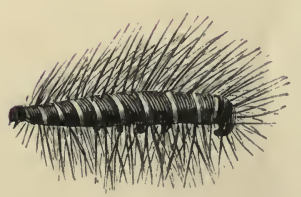

6 


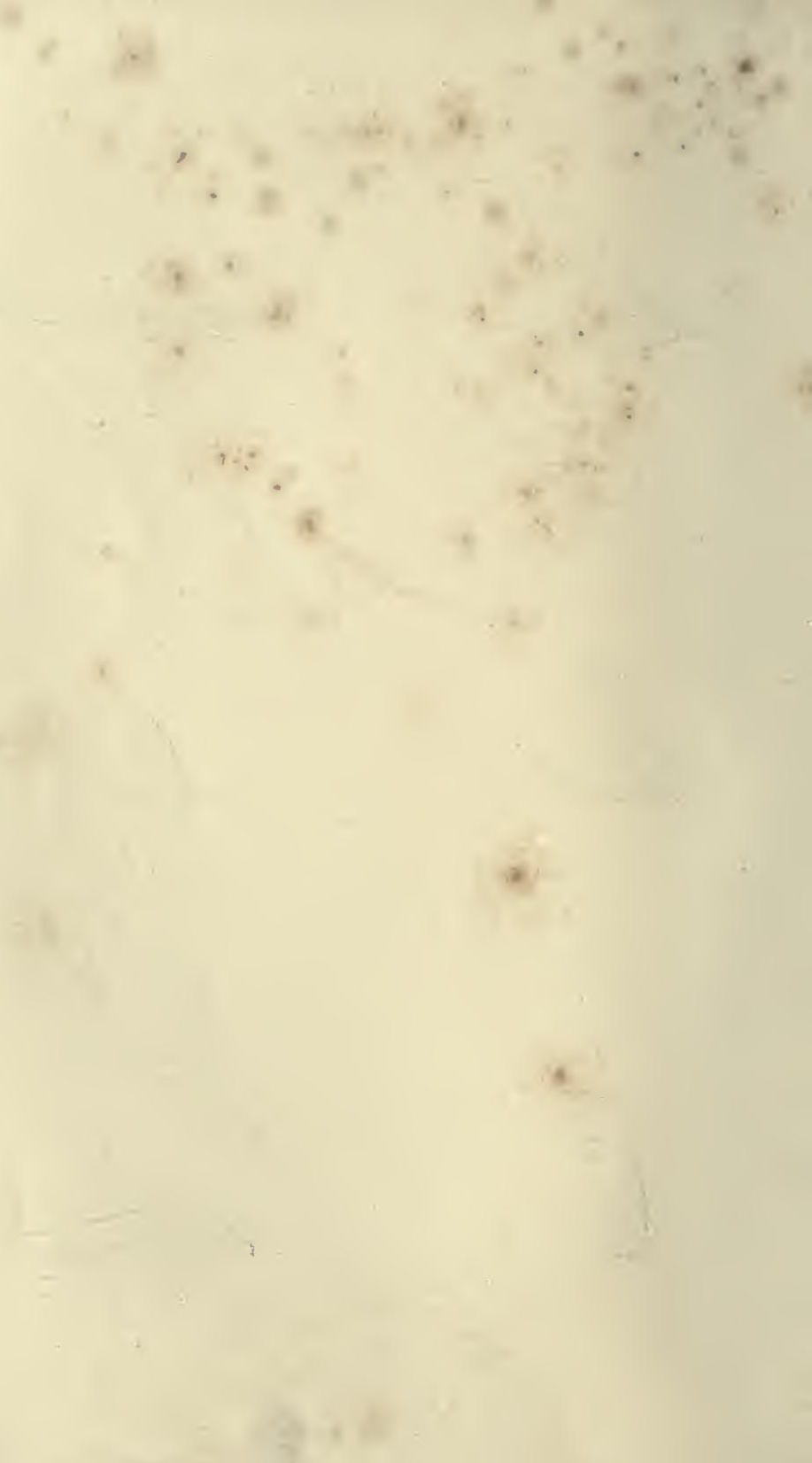




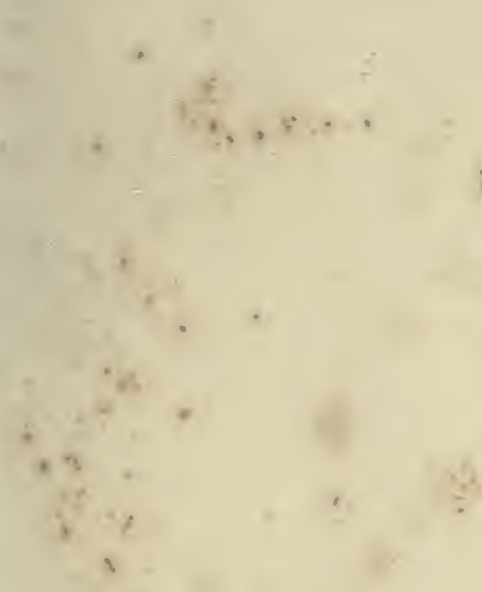

8

4

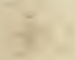




\section{PIAI'L No. 2.}
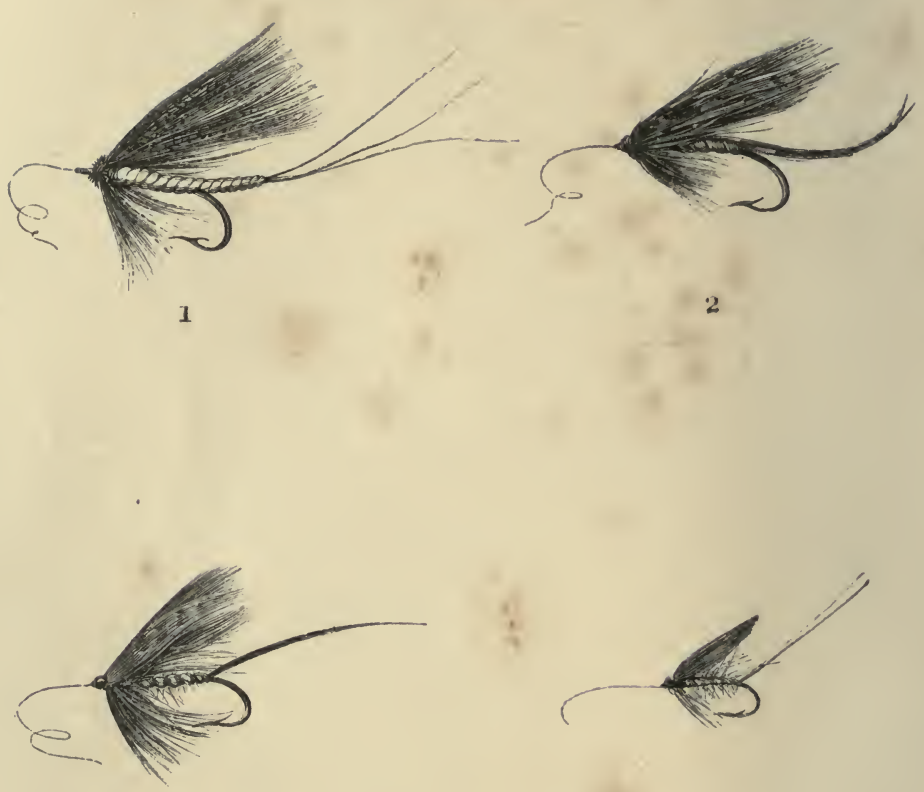

y

4

\section{2}
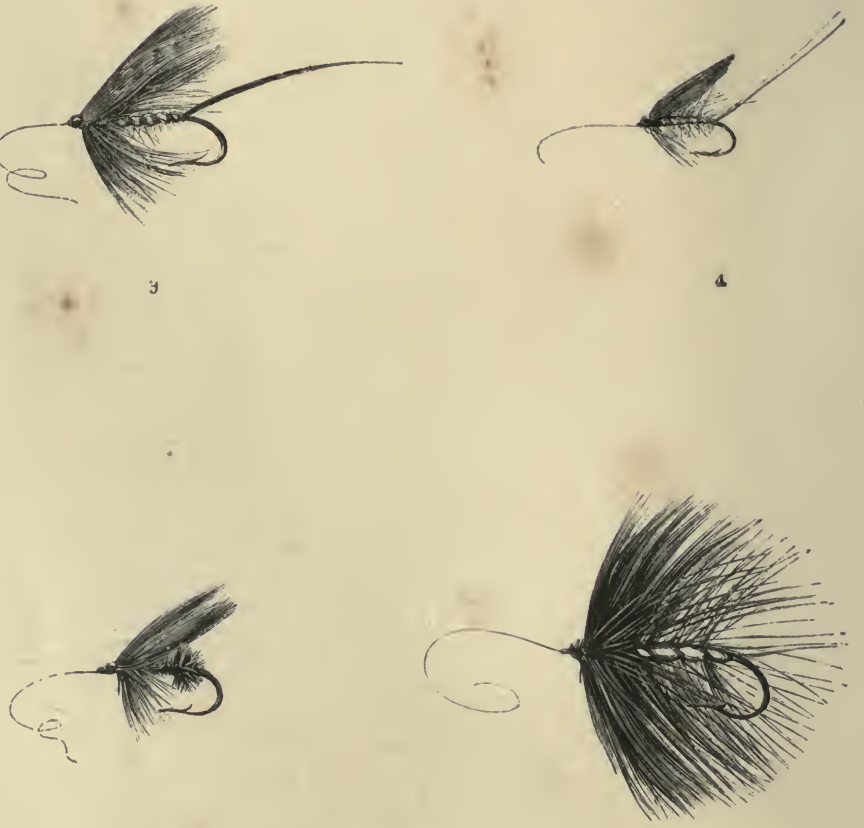
EXPLANATION OF PLATE, NO. 2.-ARTIFICIAL FLIES.

The Second Plate shows six artificial representations of the flies in the first Plate. The spectator will recognise a likeness in all of them, except in the second, the wings of which are too upright. In the water, however, those wings will lie flat. As artificial flies they are good models. In the palmer, No. 6, there is a slight defect near the bend of the hook. The fibres of the hackle-feather are not there divided with suffcient regularity. The palmer is made just as the fly No. 3 on the third Plate is made, except that there is neither tail nor wings. 


\section{EXPLANATION OF THE PLATE OF FLY-MAKING.}

WE have here diagrams representing the artificial-fly in its several stages of fabrication.

No. 1. Is what is called the hook "armed" that is to say, the hook and gut-link tied or whipped together, preparatory to putting on the wings of the fly. Hook and gut are whipped together thus :- You wax a piece of fine tying silk, about a foot or eighteen inches in length; then take your hook by the bend between the thumb and forefinger of your left hand ; make a whip or two of the waxed silk round the bare shank of the hook nearly opposite to the barb, and having done so, place your gut under the shank up to the whipping, which whipping or winding of the silk you must continue over gut and shank of hook up almost to the end. Make a slip-knot, and allow the silk to depend. Now for the wings, see-

No. 2. The wings here are partly set on. To do so, you must strip from the wing-feather of some small bird, using the longest fibres, a smallish bunch. You place them on the back of the shank of the hook, near its end, with their butts towards the bend of the hook; you tie them down with three or four whips or laps of the silk; you then cut away the fibres of the butt, and you wind your silk down the shank to the spot at which you began the arming, and leave the silk depending.

No. 3. You here see the whisks or tail set on, and the hackle-feather tied by the point and ready to be wound up to the wings. The whisks and hackle-feather are whipped on after you have finished the operations necessary for No. 2, as already described. The back of the feather must be towards you. Take it by the bared stem, and wind regularly up the hook to the wings ; wind so that the fibres will project like those of No. 4 or No. 5. When you have wound the hackle-feather up the wings, fasten it down by two or three whips of the silk over it; make a slip-knot, cut away the end of the stem, leave the silk depending, and then you will have the representation marked-

No. 4. Now pass your silk between the division of the wings, round by the butt of the half-wing on the left side of the hook, and bring the silk back again between the division, and round by the butt of the half-wing next to your. Force the wings down, forwards towards the bend of the hook, and tie them down behind the shoulder, at which spot you must 
PLATL No 3.
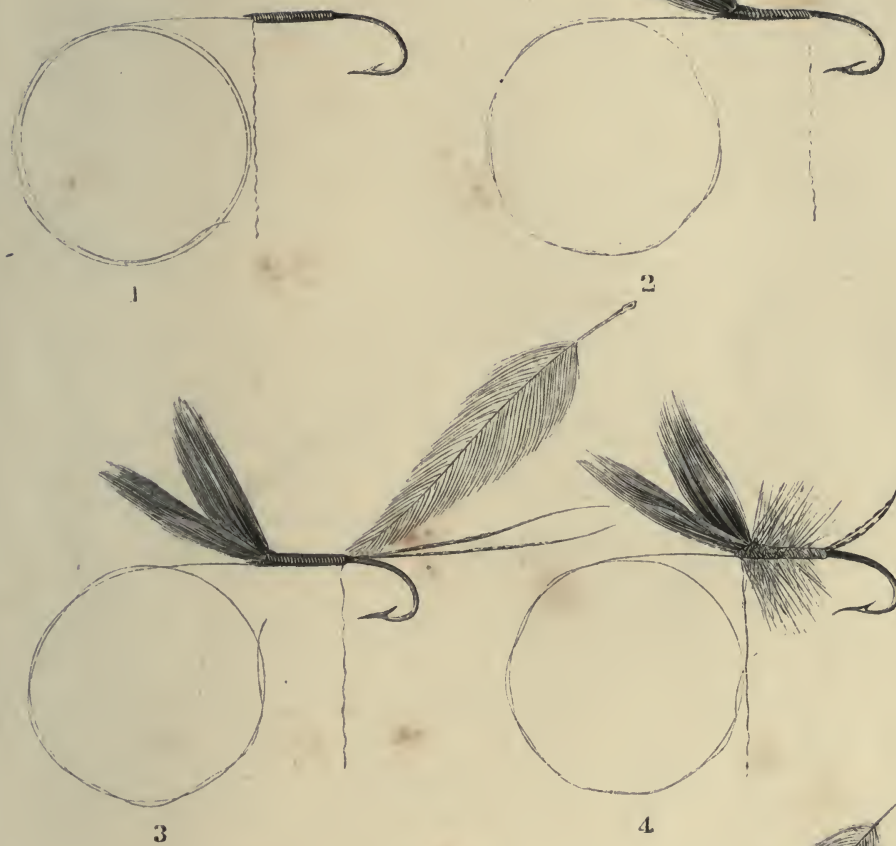

D
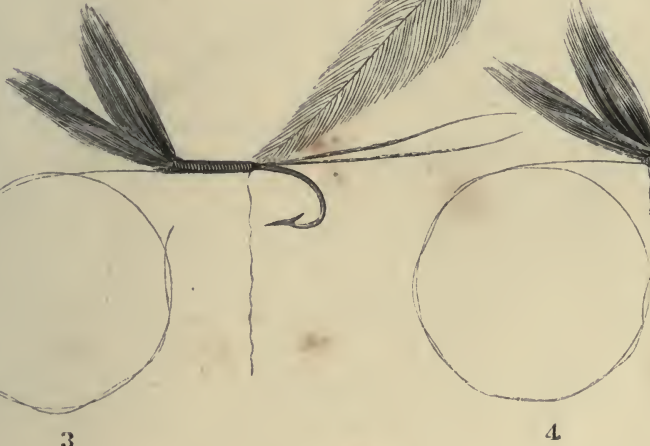

(n)

$+$
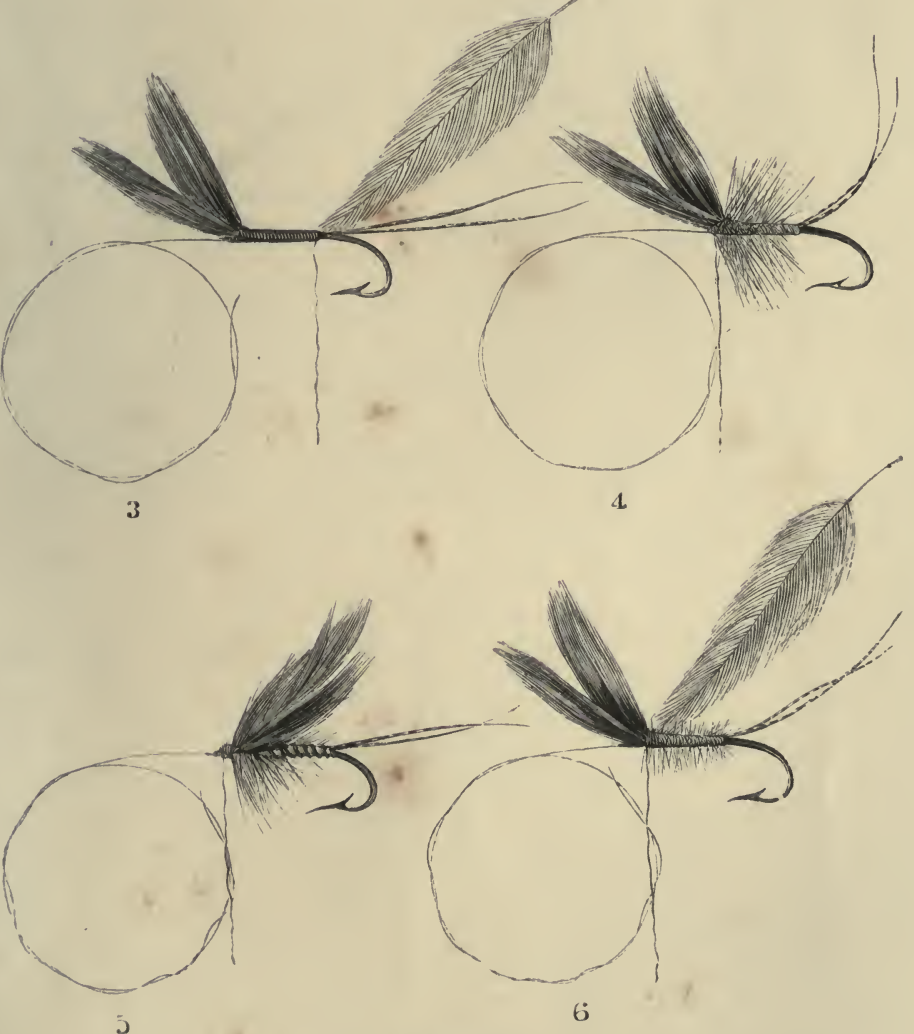

Fly Making 
$+\pi$ 
form the head of the fly, by three or four laps of the silk, and a couple of slip-knots, and then you will have diagram

No. 5. In which you have only to cut away the silk, and put a drop of varnish on the cutting to prevent the slip-knot from coming undone.

No. 6. Represents the hackle put on differently from the way shown at No. 3. The fibres seen in this diagram, No. 6, round the shank of the hook, between the tail and the wings, are a body of dubbing, of mohair or fur, which has been twisted round the silk after the tail has been fastened on, and wound up to the wings; a slip-knot was then made, and superfluous dubbing taken away. The hackle-feather was then attached as you see, and wound round two, three, or four tirnes at the wing; the stem of the hackle was then cut away, after having been tied down; and the wings arranged as clirected at No. 4, as well as the head. When it is necessary to rib the body of the fly with gold or silver twist or tinsel, tie it on immediately before your hackle, near the thick end of the tail, and then outside the tinsel tie your hackle; wind your tinsel regularly, for ribbing, up the body of the fly to the wings: fasten your tinsel down, and cut away the end. By its side wind afterwards your hackle. If no hackle is used, but simply dubbing for body, spin it on your silk and wind round shank from tail to shoulder of the fiy. Lap tinsel or twist over it, picking out dubbing for legs, and to show the tinsel.

He who shall not be able to make a trout-fly, after studying these diagrams and directions, must be deficient either in brains or in manual dexterity.

Ephemera.

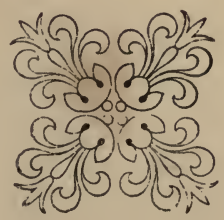





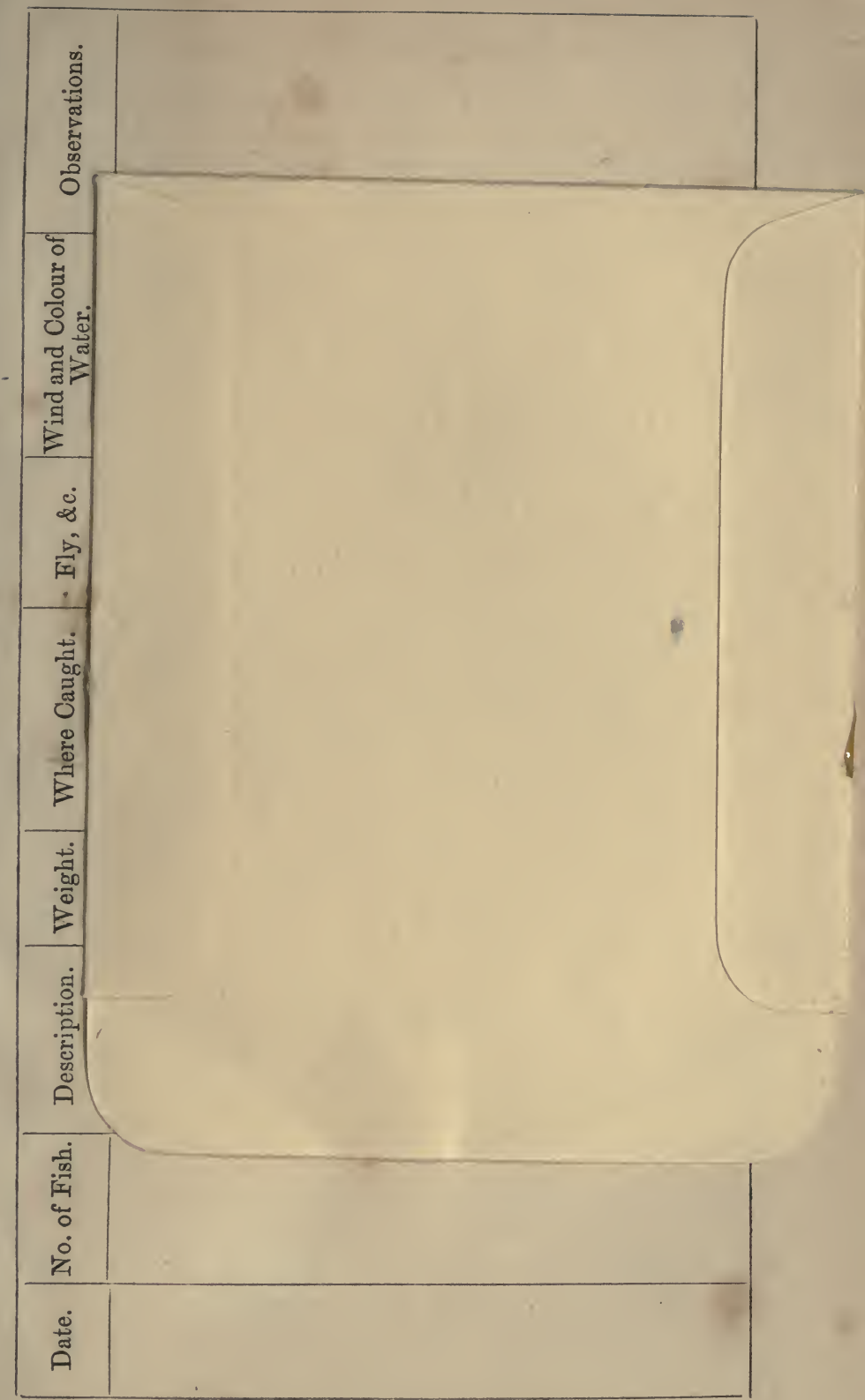


LONDOX :

SAVILL AND EDWARDS, PRINTERS, CHANDOS STREET, COVENT GARDEN. 


\section{.}

$-$ 


1. 1 1.

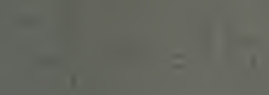
ai
t
14
18.

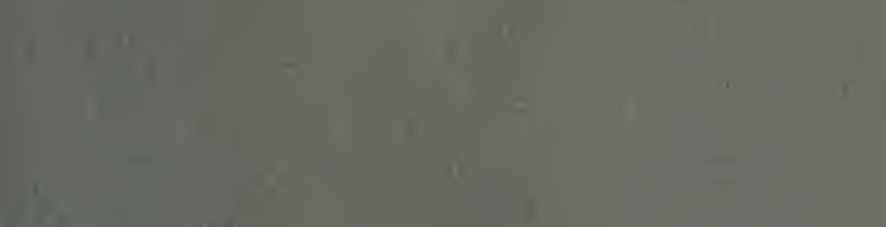

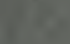

e
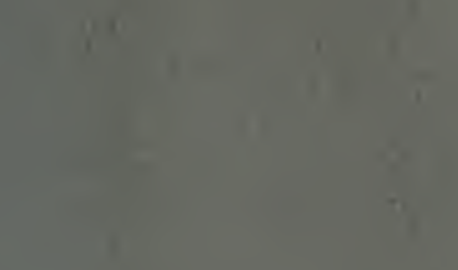

$$
\text { tit. }
$$

i) 1

$x=$

1.

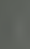

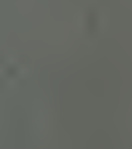

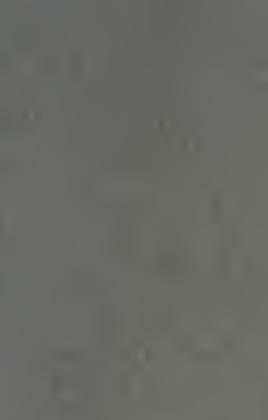

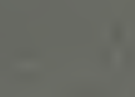

in:<smiles></smiles>

(2)

,

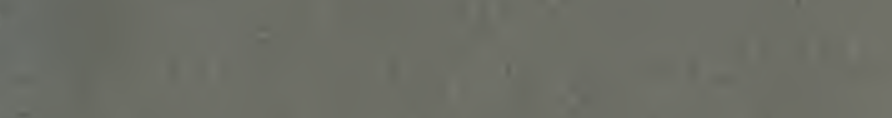

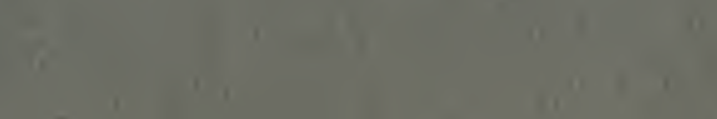


THIS BOOK IS DUE ON THE LAST DATE STAMPED BELOW

\section{AN INITIAL FINE OF 25 CENTS} WILL BE ASSESSED FOR FAILURE TO RETURN THIS BOOK ON THE DATE DUE. THE PENALTY WILL INCREASE TO 50 CENTS ON THE FOURTH DAY AND TO \$1.00 ON THE SEVENTH DAY OVERDUE.

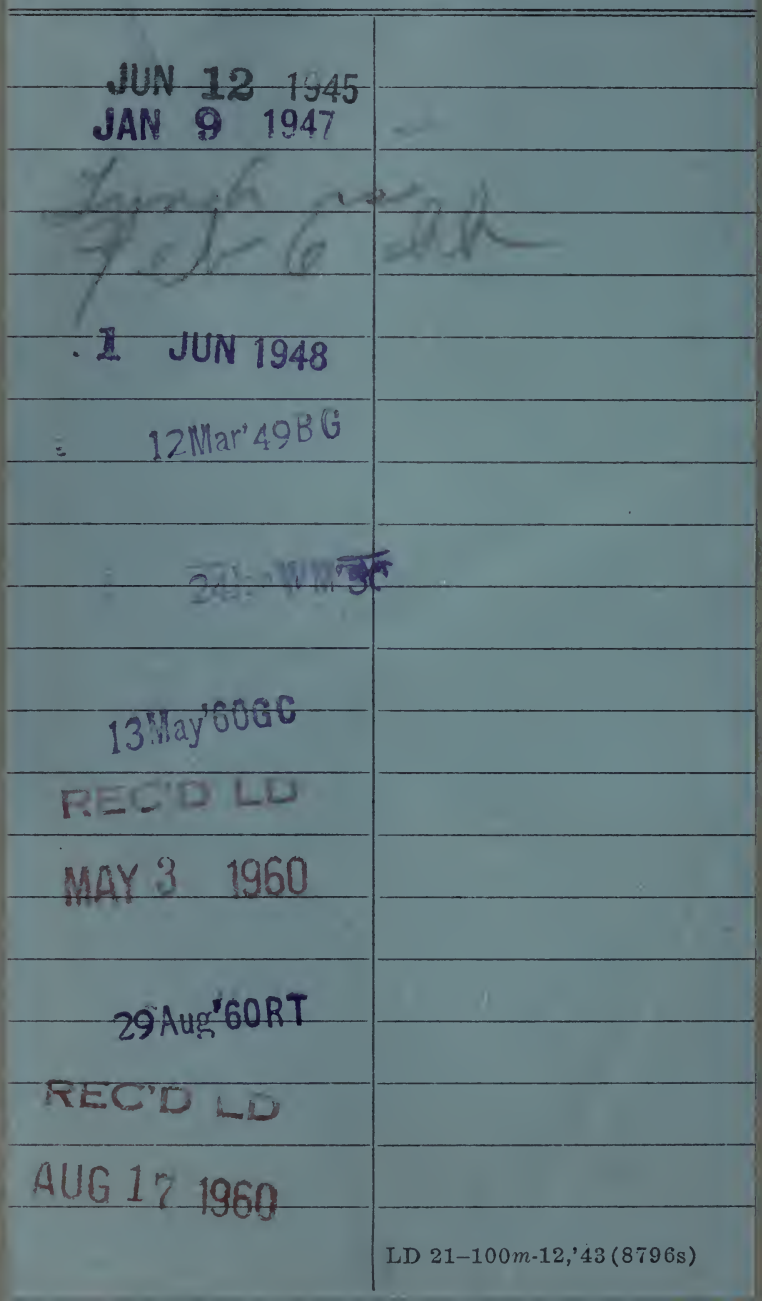




\section{YB 10614}

395679

$$
\begin{gathered}
54433 \\
A \\
1859
\end{gathered}
$$

THE UNIVERSITY OF CALIFORNIA LIBRARY 
